
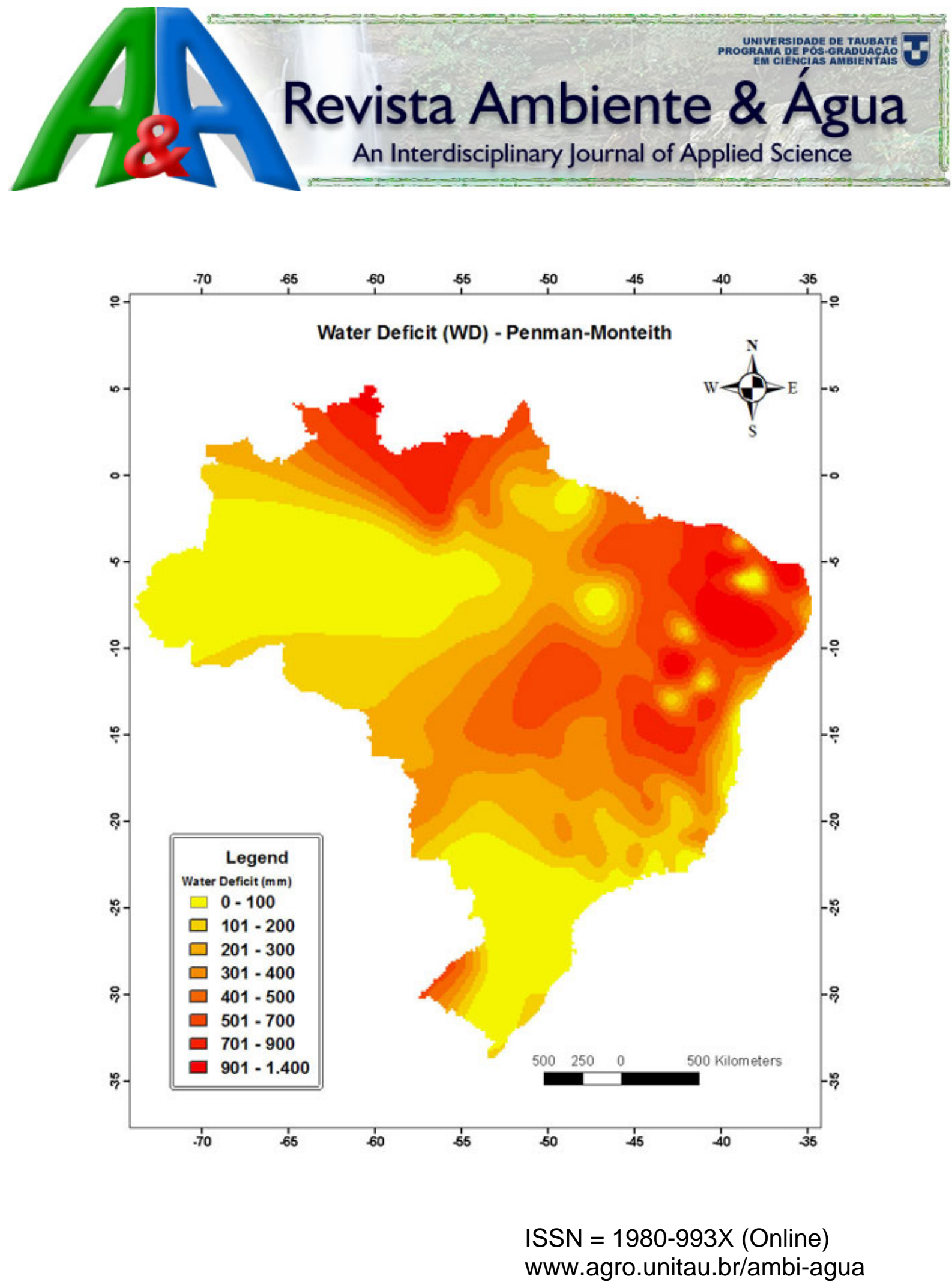

Edição 08 da Revista Ambiente \& Água - An Interdisciplinary Journal of Applied Science, Taubaté, v. 3, n. 3, p. 1-155, Dezembro 2008. (doi:10.4136/ambi-agua.v3.n3) 


\section{COMITÊ EDITORIAL}

\section{Editor}

Getulio Teixeira Batista

Instituto de Pesquisas Ambientais em Bacias Hidrográficas (IPABHi), Brasil

\section{Editores Associados}

Amaury Paulo de Souza

Universidade Federal de Viçosa (UFV), Brasil

\section{Antonio Evaldo Klar}

Universidade Estadual Paulista Júlio de Mesquita Filho, UNESP, Brasil

\section{Dar Roberts}

Universidade de Stanford; BA pela Universidade da Califórnia, EUA

Hans Raj Gheyi

Universidade Federal de Campina Grande (UFCG), Brasil

\section{Hélio Nóbile Diniz}

Instituto Geológico, Secretaria do Meio Ambiente do Estado de São Paulo (IG/SMA), Brasil

\section{João Vianei Soares}

Instituto Nacional de Pesquisas Espaciais (INPE), Brasil

Editor da Seção Editorial

Editora de Texto

Editora de Referência
Luis A. Bartolucci

Florida International University (FIU), EUA

Marcelo dos Santos Targa

Universidade de Taubaté (UNITAU), Brasil

Nelson Wellausen Dias

Universidade de Taubaté (UNITAU), Brasil

Paul W. Mausel

Indiana State University (ISU), EUA

Paulo Renato Schneider

Universidade Federal de Santa Maria (UFSM), Brasil

Sebastião do Amaral Machado

Universidade Federal do Paraná (UFPR), Brasil

Silvio Jorge Coelho Simões

Universidade Estadual Paulista Júlio de Mesquita Filho (UNESP), Brasil

Yosio Edemir Shimabukuro

Instituto Nacional de Pesquisas Espaciais (INPE), Brasil

Nelson Wellausen Dias, PPGCA, UNITAU, Brasil

Maria de Jesus Ferreira Aires, GELP, UNITAU, Brasil

Liliane Castro, Biblioteca ECA/Civil, UNITAU, Brasil

Ficha catalográfica elaborada pelo SIBi - Sistema Integrado de Bibliotecas / UNITAU

Revista Ambiente \& Água - An Interdisciplinary Journal of Applied Science / Instituto de Pesquisas Ambientais em Bacias Hidrográficas. Taubaté. v. 3, n. 3 (2006) Taubaté: IPABHi, 2008.

Quadrimestral

ISSN 1980-993X

1. Ciências ambientais. 2. Recursos hídricos. I. Instituto de Pesquisas Ambientais em Bacias Hidrográficas. III. Título. 


\section{Revisores Ad Hoc de Artigos do Ano 2008 \\ (Ambi-Agua volume 3, $n^{\circ} .1,2$ e 3, 2008)}

\begin{tabular}{|c|c|}
\hline Revisores Ad Hoc & Instituição afiliada \\
\hline Alcindo dos Santos & Universidade Federal de São Carlos (UFSCAR) \\
\hline Alexandre de Ávila Leripio & Universidade do Vale do Itajaí (UNIVALI) \\
\hline Alexandre Schiavetti & DCAA-UESC \\
\hline Alfredo Pereira & Instituto Nacional de Pesquisas Espaciais (INPE) \\
\hline Ana A. da Silva Almeida & Universidade de Taubaté (UNITAU) \\
\hline Ana Teresa Lombardi & Universidade Federal de São Carlos \\
\hline André Henrique Rosa & UNESP \\
\hline Andréa Bogatti G. Tomazela & Universidade Estadual Paulista (UNESP) \\
\hline Anne Hélène Fostier & IQ/UNICAMP \\
\hline Antonio Carlos C. Pignatari & Universidade Federal de São Paulo (UNIFESP) \\
\hline Antonio Carlos Vitte & UNICAMP \\
\hline Antonio Evaldo Klar & Universidade Estadual P. Júlio de Mesquita Filho (UNESP) \\
\hline Antonio Jose Teixeira Guerra & UFRJ \\
\hline Antonio Roberto Formaggio & Instituto Nacional de Pesquisas Espaciais (INPE) \\
\hline Antonio Teixeira Matos & DEA/UFV \\
\hline Aparecido Osdimir Bertolin & Universidade Federal do Tocantins (UFT) \\
\hline Arlindo Tribess & Escola Politécnica da USP \\
\hline Bernardo Rudorff & Instituto Nacional de Pesquisas Espaciais (INPE) \\
\hline Brani Rozemberg & Fundação Oswaldo Cruz (FIOCRUZ) \\
\hline Caetano Chang Dorea & University of Glasgow \\
\hline Camilo Daleles Rennó & Instituto Nacional de Pesquisas Espaciais (INPE) \\
\hline Carlos Ernesto Schaefer & Universidade Federal de Viçosa (UFV) \\
\hline Carlos Manoel Pedro Vaz & Empresa Brasileira de Pesquisas Agropecuária (EMBRAPA) \\
\hline Carmen Lucia Paiva Silveira & Centro Universitário Plínio Leite (UNIPLI) \\
\hline Claudia A. Linhares & Instituto Nacional de Pesquisas Espaciais (INPE) \\
\hline Claudinei Fonseca Souza & Universidade Federal de São Carlos (CCA/UFSCar) \\
\hline Claudio Luis Frankenberg & Pontifícia Universidade Católica (PUC/RS) \\
\hline Corina da Costa Freitas & Instituto Nacional de Pesquisas Espaciais (INPE) \\
\hline Denilson Teixeira & Centro Universitário de Araraquara (UNIARA) \\
\hline Denise de Castro Pereira & Pontifícia Universidade Católica (PUC/Minas) \\
\hline Douglas Gherardi & Instituto Nacional de Pesquisas Espaciais (INPE) \\
\hline Edmir Daniel Carvalho & Instituto de Biociências de Botucatu (UNESP) \\
\hline Edson Rodrigues & Universidade de Taubaté (UNITAU) \\
\hline Edson Rodrigues Filho & Universidade Federal de São Carlos (UFSCAR) \\
\hline Eduardo Marone & CEM-UFPR \\
\hline Eduardo Rodrigues V. Lima & Universidade Federal da Paraíba (UFPB) \\
\hline Eduardo Von Sperling & Universidade Federal de Minas Gerais (UFMG) \\
\hline Elmo Rodrigues da Silva & Universidade do Estado do Rio de Janeiro (UERJ) \\
\hline
\end{tabular}


Enio F. F. Silva

Eugenio Avila Pedrozo

Fabrício Sanguinetti C. Oliveira

Flavia Pinheiro Zanotto

Fúlvio Rodriguez Simão

Gerson Cardoso Silva Jr.

Getulio Teixeira Batista

Gilberto Fisch

Gilson Barbosa Athayde Júnior

Gustavo Ferreira Simões

Hélio Nobile Diniz

Herly Carlos Teixeira Dias

Herminia Yohko Kanamura

Hugo Carvalho Guerra

Hugo Moreira Soares

Humberto Calloni

Jaime Cabral

João Graciano Mendonça Filho

Joao Luiz Lani

Jorge Rubio

José Carlos Mierzwa

José Dias Corrêa Junior

José Geraldo Querido

José Guilherme Chaui-Berlinck

José Marinaldo Gleriani

Jose Renato Boucas Farias

José Rui Camargo

Luís Fernando Stone

Luiz Fernando C. Oliveira

Luiz Fernando Nascimento

Manoel Alonso Gan

Marçal José Rodrigues Pires

Marcelo dos Santos Targa

Marcelo Gattermann Perin

Márcio J. Estefano de Oliveira

Marcos Gervasio Pereira

Marcos Rivail Silva

Marcos Vinicius Folegatti

Marcus Cesar Avezum Castro

Maria Anita Mendes

Maria Cecília Prates Rodrigues

Maria Claudia Barbosa
Universidade Federal Rural de Pernambuco (UFRPE)

Universidade Federal do Rio Grande do Sul (UFRGS)

IO da Universidade de São Paulo (USP)

Universidade Presbiteriana Mackenzie

EPAMIG

Universidade Federal do Rio de Janeiro (UFRJ)

Universidade de Taubaté (UNITAU)

CSA/CTA

Universidade Federal da Paraíba (UFPB)

Universidade Federal de Minas Gerais (UFMG)

IG/Secr. do M. Ambiente do Estado de São Paulo (IG/SMA)

Universidade Federal de Viçosa (UFV)

Universidade de Taubaté (UNITAU)

Universidade Federal de Campina Grande (UFCG)

Universidade Federal de Santa Catarina (UFSC)

Fundação Universidade Federal do Rio Grande (FURGS)

Universidade Federal de Pernambuco (UFPE)

Instituto de Geociências (UFRJ)

Universidade Federal de Viçosa (UFV)

Universidade Federal do Rio Grande do Sul (UFRGS)

Universidade de São Paulo (USP)

Universidade Federal de Minas Gerais (UFMG)

Universidade de Taubaté (UNITAU)

Instituto de Biociência/USP

Universidade Federal de Viçosa (UFV)

EMBRAPA Soja

Universidade de Taubaté (UNITAU)

EMBRAPA Arroz e Feijão

Universidade Federal de Lavras/Universidade Federal de Goiás

Universidade de Taubaté (UNITAU)

Instituto Nacional de Pesquisas Espaciais (INPE)

Pontifícia Universidade Católica (PUC/RS)

Universidade de Taubaté (UNITAU)

Pontifícia Universidade Católica (PUC/RS)

Universidade de Taubaté (UNITAU)

Universidade Federal do Rio de Janeiro (UFRJ)

Universidade Regional de Blumenau (FURB)

Universidade de São Paulo (USP/ESALQ)

UNESP-RIO CLARO

Universidade de São Paulo (USP)

Universidade Federal Fluminense (UFF)

Universidade. Federal. do Rio de Janeiro (COPPE/UFRJ) 
Maria Hermínia F. Tavares

Maria Isabel Queiroz

Maria Lúcia Ribeiro

Mariko Ueno

Masato Kobiyama

Mauricio Alves Motta Sobrinho

Nelson Wellausen Dias

Orivaldo Brunini

Paul W. Mausel

Paula Benevides de Morais

Paulo Cesar Sentelhas

Paulo Fortes Neto

Paulo Renato Schneider

Paulo Romera

Rauquírio A. A. M. da Costa

Regina Peralta Moreira

Regis Alexandre Lahm

Richarde Marques Silva

Roberto José Carvalho

Ronaldo Borges Barthem

Rubem La Laina Porto

Sandro Froehner

Sebastião do Amaral Machado

Servio Tulio Cassini

Silvia Helena Govoni Brondi

Silvio Jorge Coelho Simões

Susana Inês Segura Muñoz

Tamara Maria Gomes

Teresinha Guerra

Vicente Paulo Soares

Yoshiya Nakagawara Ferreira

Yuri Tavares Rocha
Universidade Estadual do Oeste do Paraná

Fundação Universidade Federal do Rio Grande (FURG)

Centro Universitário de Araraquara (UNIARA)

Universidade de Taubaté (UNITAU)

Universidade Federal de Santa Catarina (UFSC)

Universidade Federal de Pernambuco (UFPE)

Universidade de Taubaté (UNITAU)

Instituto Agronômico de Campinas (IAC)

Indiana State University (ISU-EUA)

Universidade Federal de Tocantins (UFT)

Universidade de São Paulo (USP)

Universidade de Taubaté (UNITAU)

Universidade Federal de Santa Maria (UFSM)

CTH - Dept. Águas e Energia Elétrica de SP (DAEE)

Universidade Federal do Pará (UFPA)

Universidade Federal de Santa Catarina (UFSC)

Pontifícia Universidade Católica (PUC/RS)

Universidade Federal da Paraíba (UFPB)

Pontifícia Universidade Católica (PUC/Rio)

Museu Paraense Emílio Goeldi, PA

Escola Politécnica da USP

Universidade Federal do Paraná (UFPR)

Universidade Federal do Paraná (UFPR)

Universidade Federal Espírito Santo (UFES)

Embrapa Pecuária Sudeste

Universidade Estadual Paulista Júlio de Mesquita (UNESP)

Universidade de São Paulo (USP)

USP/Escola Superior de Agricultura Luiz de Queiroz

Universidade Federal do Rio Grande do Sul (UFRGS)

Universidade Federal de Viçosa (UFV)

Universidade Estadual de Londrina (UEL)

Faculdade de Filosofia Letras e Ciências Humanas (USP)

Obs.: 1) A lista inclui revisores que avaliaram mais de um artigo.

2) A lista inclui revisores de artigos que não foram aceitos para publicação. 


\section{Lista de Avaliadores Ad Hoc Registrados da Revista Ambiente \& Água}

Adão Benvindo Luz

Adauto de Souza Ribeiro

Adilson Pinheiro

Adonis Moreira

Adriana Sacioto Marcantonio

Adriano Wagner Ballarin

Alaide Aparecida F. Gessner

Alcindo dos Santos

Alex Vladimir Krusche

Alexandre Schiavetti

Alexandre de Avila Leripio

Alexandre Gonçalves Evsukoff

Alexandre Guirland Nowosad

Alexandre Magno Sebbenn

Alexandre Marco da Silva

Alfredo Pereira

Altemar Amaral Rocha

Ana Julia Urias Santos Araujo

Ana Aparecida da S. Almeida

Ana Teresa Lombardi

Anderson Orestes C. Lobato

André Henrique Rosa

Andréa Bogatti G. Tomazela

Ângela dos Santos Barretto

Anne Hélène Fostier

Annemarie Konig

Antonio Caetano V. Caltabiano

Antonio Carlos C. Pignatari

Antonio Carlos Vitte
Centro de Tecnologia Mineral

Universidade Federal de Sergipe

Universidade Regional de Blumenau

EMBRAPA Pecuária Sudeste

Agência Paulista de Tecnologia dos Agronegócios

Univ. Est. Paulista - Fac. Ciências Agronômicas

Universidade Federal de São Carlos (USFSCAR)

Universidade Federal de São Carlos

Universidade de São Paulo (USP-CENA)

Universidade Estadual de Santa Cruz

Universidade do Vale do Itajaí

Universidade Federal do Rio de Janeiro (COPPE)

Instituto Nacional de Pesquisas Espaciais (INPE)

Instituto Florestal de São Paulo (SMA-IF)

UNESP Sorocaba

Instituto Nacional de Pesquisas Espaciais (INPE)

Universidade Federal da Paraíba (UFPB)

Universidade de Taubaté (UNITAU)

Universidade de Taubaté (UNITAU)

Universidade Federal de São Carlos (UFSCAR)

Universidade Federal de Pelotas

Universidade Estadual Paulista (UNESP Sorocaba)

UNESP Campus Experimental do Litoral Paulista

Universidade de Campinas (UNICAMP)

IQ - Universidade de Campinas (UNICAMP)

Universidade Federal de Campina Grande (UFCG)

International Clivar Project Office

Universidade Federal de São Paulo (UNIFESP)

Universidade de Campinas (UNICAMP) 
Antonio César Ortega

Antonio-Evaldo-Klar

Antonio Jose Teixeira Guerra

Antonio Roberto Formaggio

Antonio Teixeira Matos

Aparecido Osdimir Bertolin

Arimatéa Carvalho Ximenes

Arlindo Tribess

Áureo Eduardo M. Ribeiro

Bernardo Rudorff

Brani Rozemberg

Caetano Chang Dorea

Camilo Daleles Rennó

Carlos Andre Bulhões Mendes

Carlos Alberto V. de Azevedo

Carlos Edwar Freitas

Carlos Ernesto Schaefer

Carlos Manoel Pedro Vaz

Carlos Rogério Mello

Carmen Lidia A. P. Zottarelli

Carmen Lucia Paiva Silveira

Catarina da Silva Pedrozo

Cecília Volkmer Ribeiro

Celso Augusto Guimarães Santos

César Ulisses Vieira Veríssimo

César Augusto Moreira

Chigueru Tiba

Cilene Gomes

Claudia Albuquerque Linhares

Claudinei Fonseca Souza

Claudio José Von Zuben
Universidade Federal de Uberlândia

Universidade Estadual Paulista (UNESP Botucatu)

Universidade Federal do Rio de Janeiro (UFRJ)

Instituto Nacional de Pesquisas Espaciais (INPE)

Universidade Federal de Viçosa (UFV)

Universidade Federal do Tocantins (UFTO)

Instituto Nacional de Pesquisas Espaciais (INPE)

Escola Politécnica da USP (Poli USP)

Universidade Federal de Lavras (UFLA)

Instituto Nacional de Pesquisas Espaciais (INPE)

Fundação Oswaldo Cruz (FIOCRUZ)

University of Glasgow

Instituto Nacional de Pesquisas Espaciais (INPE)

Instituto de Pesquisas Hidráulicas (UFRGS)

Universidade Federal de Campina Grande (UFCG)

Universidade Federal do Amazonas

Universidade Federal de Viçosa (UFV)

CNPDIA - EMBRAPA

Universidade Federal de Lavras (UFLA)

Instituto de Botânica de São Paulo

Centro Universitário Plínio Leite (UNIPLI)

Universidade Federal do Rio Grande do Sul (UFRGS)

Fundação Zoobotânica do RGS

Universidade Federal da Paraíba (UFPB)

Universidade Federal do Ceará (UFC)

USP - Escola de Engenharia de São Carlos

Universidade Federal de Pernambuco (UFPE)

Universidade Federal do Rio de Janeiro (UFRJ)

Instituto Nacional de Pesquisas Espaciais (INPE)

Universidade Federal de São Carlos (UFSCAR)

UNESP Rio Claro 
Claudio Luis Frankenberg

Cleber Salimon

Corina da Costa Freitas

Cyro Barros Rezende-Filho

Denilson Teixeira

Denise de Castro Pereira

Dirceu Luis Herdies

Douglas Francisco M. Gherardi

Durval Dourado

Edmir Daniel Carvalho

Edson Rodrigues

Edson Rodrigues Filho

Eduardo Antonio G. Marques

Eduardo Marone

Eduardo Pereira Cabral Gomes

Eduardo Rodrigues V. de Lima

Eduardo von Sperling

Elmo Rodrigues da Silva

Emilia de Rodat F. Moreira

Enio F. F. Silva

Enner Herenio Alcântara

Ernani Francisco da Rosa Filho

Eugenio Avila Pedrozo

Evlyn Márcia Novo

Fabio Laurindo da Silva

Fábio Marcelo Breunig

Fabrício Sanguinetti C. Oliveira

Flávia Cristina Sossae

Flavio Cesar B. Mascarenhas

Flávio Jorge Ponzoni

Flavio Jose Malta
Pontifícia Univ. do Rio Grande do Sul (PUC-RS)

Universidade Federal do Acre (UFAC)

Instituto Nacional de Pesquisas Espaciais (INPE)

Universidade de Taubaté (UNITAU)

Centro Universitário de Araraquara (UNIARA)

Pontifícia Univ. Católica de Minas Gerais (PUC-MG)

Instituto Nacional de Pesq. Espaciais (CPTEC-INPE)

Instituto Nacional de Pesquisas Espaciais (INPE)

Universidade de São Paulo (USP-ESALQ)

Instituto de Biociências (UNESP Botucatu)

Universidade de Taubaté (UNITAU)

Universidade Federal de São Carlos (UFSCAR)

Universidade Federal de Viçosa (UFV)

Universidade Federal do Paraná (UFPR)

Instituto de Botânica

Universidade Federal da Paraíba (UFPB)

Universidade Federal de Minas Gerais (UFMG)

Universidade do Estado do Rio de Janeiro (UERJ)

Universidade Federal da Paraíba (UFPB)

Universidade Federal Rural de Pernambuco (UFPE)

Instituto Nacional de Pesquisas Espaciais (INPE)

Universidade Federal do Paraná (UFPR)

Universidade Federal do Rio Grande do Sul (UFGRS)

Instituto Nacional de Pesquisas Espaciais (INPE)

Universidade Federal de São Carlos (UFSCAR)

Instituto Nacional de Pesquisas Espaciais (INPE)

Inst. Ocean. da Universidade de São Paulo (IO-USP)

Centro Universitário de Araraquara (UNIARA)

Universidade Federal do Rio de Janeiro (UFRJ)

Instituto Nacional de Pesquisas Espaciais (INPE)

Universidade de Taubaté (UNITAU) 
Francisco de Sousa Ramos

Francisco Gonçalves da Silva

Francisco Roberto Azevedo

Fúlvio Rodriguez Simão

Georgina Bond Buckup

Gerson Cardoso Silva Jr.

Getulio Rincon

Getulio Teixeira Batista

Gilberto Fisch

Gilson Barbosa Athayde Júnior

Glicério Trichês

Gustavo Ferreira Simões

Helena Carvalho Lorenzo

Helio Grassi Filho

Hélio Nóbile Diniz

Herickson Akihito Sudo Lutif

Herly Carlos Teixeira Dias

Hermann Johann Heinrich Kux

Herminia Yohko Kanamura

Homero Giorge Cerqueira

Horst Frischkorn

Hugo Carvalho Guerra

Hugo Moreira Soares

Humberto Calloni

Ijar Milagre da Fonseca

Iraê Amaral Guerrini

Itamar Alves Martins

Jacob Binsztok

Jaime Cabral

Jairo José de Oliveira Andrade

Jarbas Bonetti
Universidade Federal de Pernambuco (UFPE)

Universidade Federal da Paraíba (UFPB)

Universidade Federal do Ceará

Empresa de Pesq. Agrop. de Minas Gerais (EPAMIG)

Universidade Federal do Rio Grande do Sul (UFRGS)

Universidade Federal do Rio de Janeiro (UFRJ)

Conselho Nac. de Pesca e Aqüicultura (CONEPE)

Universidade de Taubaté (UNITAU)

Universidade de Taubaté (UNITAU) / CSA-CTA

Universidade Federal da Paraíba (UFPB)

Universidade Federal de Santa Catarina (UFSC)

Universidade Federal de Minas Gerais (UFMG)

Centro Universitário de Araraquara (UNIARA)

Universidade Estadual Paulista (UNESP Botucatu)

Instituto Geo. do Est. de São Paulo (IG-SMA/SP)

Universidad Carlos III de Madrid

Universidade Federal de Viçosa (UFV)

Instituto Nacional de Pesquisas Espaciais (INPE)

Universidade de Taubaté (UNITAU)

Policia Militar (APMBB)/ Univ. Cruzeiro do Sul

Universidade Federal do Ceará (UFCE)

Universidade Federal de Campina Grande (UFCG)

Universidade Federal de Santa Catarina (UFSC)

Fundação Universidade Federal do Rio Grande

Instituto Nacional de Pesquisas Espaciais (INPE)

Universidade Estadual Paulista (UNESP Botucatu)

Univ. Est. P. Júlio de Mesquita Filho (UNESP)

Universidade Federal Fluminense (UFF)

Universidade Federal de Pernambuco (UFPE)

Pontifícia Univ. do Rio Grande do Sul (PUC-RS)

Universidade Federal de Santa Catarina (UFSC) 
João Carlos Pinheiro Beck

João Graciano Mendonça Filho

João Luiz Lani

João Vianei Soares

Joel Avruch Goldenfum

Jorge Rubio

Jorge Xavier da Silva

José Alberto Quintanilha

José Antonio Perrella Balestieri

José Carlos Becceneri

José Carlos de Araújo

José Carlos Mierzwa

José Dantas Neto

José Dias Corrêa Junior

José Eduardo dos Santos

José Eloi Guimarães Campos

José Euclides Stipp Paterniani

José Geraldo Querido

José Marques da Costa

José Marinaldo Gleriani

José Renato Boucas Farias

José Rui Camargo

Juliana Cristina Barreiro

Jurandir Zullo

Leandro Redin Vestena

Leonardo Santos Collier

Leonor Almeida Souza-Soares

Lia Osório Machado

Lidriana de Souza Pinheiro

Lino Carlos Borges

Loreley Gomes Garcia
Pontifícia Univ. do Rio Grande do Sul (PUC-RS)

IG da Universidade Federal do Rio de Janeiro (UFRJ)

Universidade Federal de Viçosa (UFV)

Instituto Nacional de Pesquisas Espaciais (INPE)

Universidade Federal do Rio Grande do Sul (UFRGS)

Universidade Federal do Rio Grande do Sul (UFRGS)

Universidade Federal do Rio de Janeiro (UFRJ)

Escola Politécnica da Univ. de São Paulo (Poli-USP)

UNESP Guaratinguetá

Instituto Nacional de Pesquisas Espaciais (INPE)

Universidade Federal do Ceará (UFCE)

Universidade de São Paulo (USP)

Universidade Federal de Campina Grande (UFCG)

Universidade Federal de Minas Gerais (UFMG)

Universidade Federal de São Carlos (UFSCAR)

Universidade de Brasília (UnB)

Universidade de Campinas (UNICAMP)

Universidade de Taubaté (UNITAU)

Universidade de Taubaté (UNITAU)

Universidade Federal de Viçosa (UFV)

EMBRAPA Soja

Universidade de Taubaté (UNITAU)

Universidade Federal de São Carlos (UFSCAR)

C. Pesq. Met. e Clim. Apl. a Agric. (UNICAMP)

Universidade Estadual do Centro-Oeste do Paraná

Universidade Federal do Tocantins (UFTO)

Fundação Universidade Federal do Rio Grande

Universidade Federal do Rio de Janeiro (UFRGS)

Universidade Estadual do Ceará (UFCE)

Agência Goiana de Desenv. Rural e Fundiário

Universidade Federal da Paraíba (UFPB) 
Lucia Maria Sa Antunes Costa

Luciana Sarmento

Luciano Farinha Watzlawick

Luis Alberto Basso

Luis Antônio Serrão Contim

Luis Eduardo Aragon

Luís Fernando Stone

Luiz Carlos Laureano da Rosa

Luiz Eduardo Oliveira

Luiz Fernando Coutinho Oliveira

Luiz Fernando Nascimento

Magda Adelaide Lombardo

Manoel Alonso Gan

Mara Regina Rizzatti

Marçal José Rodrigues Pires

Marcelo dos Santos Targa

Marcelo Friederichs L. Souza

Marcelo Santos Chaves

Márcio Balbino Cavalcante

Márcio J. Estefano de Oliveira

Marco Antonio Igarashi

Marcos Adami

Marcos Gervasio Pereira

Marcos Rivail Silva

Marcos Vinícius Folegatti

Marcus Cesar Avezum Castro

Maria Anita Mendes

Maria Cecília Prates Rodrigues

Maria Claudia Barbosa

Maria Cristina Crispim

Maria Cristina Vidotte B. Tarrega
Universidade Federal do Rio de Janeiro (UFRJ)

Agência Nacional de Águas (ANA)

Universidade Estadual do Centro-Oeste

Universidade Federal do Rio Grande do Sul

Centro Educacional Adalberto Valle (CEAV)

Universidade Federal do Pará (UFPA)

EMBRAPA Arroz e Feijão

Universidade de Taubaté (UNITAU)

Universidade Estadual Paulista - Guaratinguetá

Univ. Fed. Lavras/Univ. Fed. Goiás (UFLA/UFGO)

Universidade Estadual Paulista (UNESP)/UNITAU

Universidade Estadual Paulista (UNESP Rio Claro)

Instituto Nacional de Pesquisas Espaciais (INPE)

Pontifícia Univ. do Rio Grande do Sul (PUC-RGS)

Pontifícia Univ. do Rio Grande do Sul (PUC-RGS)

Universidade de Taubaté (UNITAU)

Universidade Estadual de Santa Cruz

Universidade Federal da Paraíba (UFPB)

Universidade Estadual da Paraíba

Universidade de Taubaté (UNITAU)

Universidade Federal do Ceará (UFCE)

Instituto Nacional de Pesquisas Espaciais (INPE)

Universidade Federal do Rio de Janeiro (UFRJ)

Universidade Regional de Blumenau

Universidade de São Paulo - ESALQ

Univ. Estadual Paulista (UNESP rio Claro)

Universidade de São Paulo (USP)

Universidade Federal Fluminense (UFF)

Universidade Federal do Rio de Janeiro (UFRJ)

Universidade Federal da Paraíba (UFPB)

Universidade Federal de Goiás (UFGO) 
Maria do Carmo Vieira

Maria Dolores Alves Cocco

Maria Elaine de Oliveira

Maria Helena Arruda Leme

Maria Hermínia Ferreira Tavares

Maria Inês Salgueiro Lima

Maria Isabel Queiroz

Maria Jesus Robim

Maria Lúcia Ribeiro

Mariko Ueno

Mário Augusto Jardim

Marisete Dantas Aquino

Marta Bustos Romero

Masato Kobiyama

Mauricio Alves Alves Moreira

Maurício Alves da Motta Sobrinho

Messias Borges Silva

Milton Kampel

Neida Patias Volpi

Nelson Wellausen Dias

Nestor Aldo Campana

Néstor Antonio Heredia Zárate

Ney Augusto Nascimento

Orivaldo Brunini

Osmar Alves Lameira

Pablo Santana Santos

Patrick Thierry Seyler

Paul W. Mausel

Paula Benevides de Morais

Paulo Cesar Sentelhas

Paulo Fortes Neto
Universidade Federal da Grande Dourados

Universidade de Taubaté (UNITAU)

Universidade Federal Fluminense (UFF)

Universidade Presbiteriana Mackenzie

Universidade Estadual do Oeste do Paraná

Universidade Federal de São Carlos (UFSCAR)

Fundação Universidade Federal do Rio Grande

Instituto Florestal/SMA-SP

Univ. Estadual Paulista UNESP Araraquara

Universidade de Taubaté (UNITAU)

Museu Paraense Emilio Göeldi, PA

Universidade Federal do Ceará (UFCE)

Universidade de Brasília (UnB)

Universidade Federal de Santa Catarina (UFSC)

Instituto Nacional de Pesquisas Espaciais

Universidade Federal de Pernambuco

Universidade de São Paulo (USP)

Instituto Nacional de Pesquisas Espaciais (INPE)

Universidade Federal do Paraná (UFPR)

Universidade de Taubaté (UNITAU)

Universidade de Brasília (UnB)

Universidade Federal da Grande Dourados

Universidade Federal do Paraná (UFPR)

Instituto Agronômico de Campinas (IAC)

EMBRAPA Amazônia Oriental

Instituto Nacional de Pesquisas Espaciais (INPE)

Universidade de Brasília (UnB)

Indiana State University (ISU)

Universidade Federal do Tocantins (UFTO)

Universidade de São Paulo (USP-ESALQ)

Universidade de Taubaté (UNITAU) 
Paulo Renato Schneider

Paulo Roberto Cecon

Paulo Roberto Meneses

Paulo Romera e Silva

Paulo Sergio Graziano Magalhães

Pedro R. Jacobi

Pedro Teixeira Lacava

Rauquírio André A. M. da Costa

Regina Peralta Moreira

Regis Alexandre Lahm

Reinaldo José da Silva

Rejane Magalhães de M. Pimentel

Renato Fontes Guimarães

Renato Mello Prado

Ricardo Santos

Richarde Marques Silva

Roberto de Oliveira

Roberto José Carvalho

Roberto Luiz Carmo

Rogério Nora Lima

Ronaldo Borges Barthem

Ronaldo Viana Soares

Rosa Maria Formiga Johnsson

Rouverson Pereira da Silva

Rubem La Laina Porto

Sandro Froehner

Sebastião do Amaral Machado

Serafim Daniel Ballestero

Sérgio Campos

Sergio Nascimento Duarte

Servio Tulio Cassini
Universidade Federal de Santa Maria (UFSM)

Universidade Federal de Viçosa (UFV)

Universidade de Brasília (UnB)

CTH - Dept. Águas e Energia Elétrica de SP (DAEE)

Universidade de Campinas (UNICAMP)

Universidade de São Paulo (USP)

Instituto Tecnológico de Aeronáutica (ITA)

Universidade Federal do Pará (UFPA)

Universidade Federal de Santa Catarina (UFSC)

Pontifícia Univ. Cat. do R. G. do Sul (PUC-RS)

Universidade Estadual Paulista

Universidade Federal Rural de Pernambuco

Universidade de Brasília

Universidade Estadual Paulista Campus Jaboticabal

Universidade Federal de Viçosa

Universidade Federal da Paraíba

Universidade Federal de Santa Catarina

Pontifícia Universidade Católica do Rio de Janeiro

Universidade de Campinas

Centro Federal de Educação Tecnológica do Piauí

Museu Paraense Emílio Göeldi, PA

Universidade Federal do Paraná

Universidade do Estado do Rio de Janeiro

Universidade Estadual Paulista/Jaboticabal

Escola Politécnica da USP (Poli USP)

Universidade Federal do Paraná (UFPR)

Universidade Federal do Paraná (UFPR)

Universidade de Taubaté (UNITAU)

Universidade Estadual Paulista (UNESP Botucatu)

E. S. de Agric. "Luiz de Queiroz" (USP-ESALQ)

Universidade Federal do Espírito Santo (UFES) 
Shiguenoli Miyamoto

Silvia Helena Govoni Brondi

Silvio Jorge Coelho Simões

Simey Thury Vieira Fisch

Simone Pinheiro Pereira

Solon Jonas Longhi

Sonia Cristina J. G. de A. Perez

Stelio Maia Menezes

Susana Inés Segura Muñoz

Tamara Maria Gomes

Teresinha Guerra

Thereza Christina Almeida Rosso

Thomaz Correa e Castro Costa

Ubirajara Aluizio Mattos

Ubiratan Ferrucio Faccini

Ulisses Thadeu Vieira Guedes

Valdemar Luiz Tornisielo

Valdira de Caldas Brito Vieira

Vera Lucia Antunes Lima

Vicente de Paulo Rodrigues Silva

Vicente Paulo Soares

Walter de Paula Lima

Washington Franca Rocha

Yanko Marcius de Alencar Xavier

Yoshiya Nakagawara Ferreira

Yosio Edemir Shimabukuro

Yuri Tavares Rocha
Universidade Estadual de Campinas (UNICAMP)

EMBRAPA Pecuária Sudeste

UNESP Guaratinguetá

Universidade de Taubaté (UNITAU)

Universidade Federal do Pará (UFPA)

Universidade Federal de Santa Maria (UFSM)

Universidade Federal de São Carlos (UFSCAR)

Universidade Federal de Lavras (UFLA)

Universidade de São Paulo (USP)

E. S. de Agric. "Luiz de Queiroz" (USP-ESALQ)

Univ. Federal do Rio Grande do Sul (UFRGS)

Universidade do Estado do Rio de Janeiro (UFRJ)

Empresa Bras. de Pesq. Agropecuária (EMBRAPA)

Universidade do Estado do Rio de Janeiro (UFRJ)

Universidade do Vale do Rio dos Sinos

Instituto Nacional de Pesquisas Espaciais (INPE)

Universidade de São Paulo (USP)

Centro Federal de Educação Tecnológica do Piauí

Universidade Federal de Campina Grande (UFCG)

Universidade Federal de Campina Grande (UFCG)

Universidade Federal de Viçosa (UFV)

Universidade de São Paulo (USP)

Universidade Estadual de Feira de Santana

Universidade Federal do Rio Grande de Norte

Universidade Estadual de Londrina (UEL)

Instituto Nacional de Pesquisas Espaciais (INPE)

Universidade de São Paulo (USP) 


\section{ÍNDICE}

\section{CAPA}

Water deficit map for Brazil, based on Thornthwaite and Mather water balance, for soil water holding capacity of $100 \mathrm{~mm}$, with potential evapotranspiration estimated by Penman-Monteith method.

Fonte: SENTELHAS, P. C.; SANTOS, D. L.; MACHADO, R. E. Water deficit and water surplus maps for Brazil, based on FAO Penman-Monteith potential evapotranspiration. Ambi-Agua, Taubaté, v. 3, n. 3, p. 28-42, 2008. (doi:10.4136/ambi-agua.59)

\section{EDITORIAL}

Ambiente e Água: a journal on the rise (doi:10.4136/ambi-agua.57)

Getulio Teixeira Batista

\section{ARTIGOS}

Heterotrophic components of soil respiration in pastures and forests in southwestern Amazonia, Acre, Brazil (doi:10.4136/ambi-agua.58)

Cleber I. Salimon; Eric A. Davidson

Water deficit and water surplus maps for Brazil, based on FAO Penman-Monteith potential evapotranspiration (doi:10.4136/ambi-agua.59)

Paulo C. Sentelhas; Dayana L. dos Santos; Ronalton E. Machado

Rainfall-runoff process analysis of the Pequeno River catchment, Curitiba metropolitan region, Brazil, with two hydrological models (doi:10.4136/ambi-agua.60)

Pedro L. B. Chaffe; Roberto V. da Silva; Masato Kobiyama

Studies on contaminant transport at an industrial waste dumpsite of Bangalore, India (doi:10.4136/ambi-agua.61)

Syed A. S. Mohammed; Maya Naik; Sanaulla P. Fakruddin; Zulfiqar A. M. Nazeer

Variabilidade espacial de vazão e pressão em subunidade de microaspersão com emissores usados e novos (doi:10.4136/ambi-agua.62)

Wagner W. A. Alves; José Dantas Neto; José A. Matos; Carlos A. V. de Azevedo; Vera L. A. de Lima

Disposição no solo de efluentes de esgoto tratado visando à redução de coliformes termotolerantes (doi:10.4136/ambi-agua.63)

Teresa B. C. Ribas; Paulo F. Neto

Determinação de trechos de importância em sistemas de distribuição de água usando a vulnerabilidade hidráulica (doi:10.4136/ambi-agua.64)

Zacarías Navarro-Roa; Maurício L. Sens; Ramon L. Dalsasso; Bruno S. Pizzolatti

Economia de água na irrigação do coqueiro em função de áreas de maior concentração do sistema radicular e cobertura do solo (doi:10.4136/ambi-agua.65)

Ivandelson S. Santos; Carlos A. V. de Azevedo; Hugo O. C. Guerra; Frederico A. L. Soares;

Vera L. A. de Lima; José Dantas Neto

Avaliação da qualidade da água dos mananciais na ilha de Fernando de Noronha (doi:10.4136/ambi-agua.66)

Maurício da Motta; Valdinete L. Silva; Abelardo A. A. Montenegro; Suzana M. G. L.

Montenegro; Marcus M. Correa

Principais usos da água do rio Sanhauá na área de influência do antigo lixão do Roger: proposta de revisão de enquadramento do rio (doi:10.4136/ambi-agua.67)

Gilson B. Athayde. Júnior; Claudia C. Nóbrega; Carmem L. M. Gadelha; Natalia C. B. Santana; Magdalena D. Costa

Protocolos de avaliação rápida de rios e a inserção da sociedade no monitoramento dos 


ISSN = 1980-993X - doi:10.4136/1980-993X
www.agro.unitau.br/ambi-agua
E-mail: ambi-agua@agro.unitau.br
Tel.: (12) 3625-4116

\title{
Ambiente e Água: a journal on the rise (doi:10.4136/ambi-agua.57)
}

\author{
Getulio Teixeira Batista \\ Professor at the Master Degree Program in Environmental Sciences of the University of Taubaté \\ Estrada Municipal Dr. José Luiz Cembranelli, 5.000; Bairro Itaim; 12.081-010 - Taubaté, SP \\ E-mail: ambi-agua@agro.unitau.br
}

\begin{abstract}
Ambiente e Água - An International Journal of Applied Science just published its eighth issue, completing the third number of its third volume with all issues published on time. The number of submissions increased significantly and as a result the number of published papers. Eleven articles were published in this issue. The geographic and institutional origin of authors also increased not only throughout Brazil, but also from abroad. First authors came from 28 different institutions in Brazil from all over the country and from 5 different institutions from abroad. The average number of weekly visitors increased from 300 per week in 2007 to 700 recently. The international interest in the journal is clearly evidenced by the number of countries and geographical coverage of readers. One significant improvement was the increased number of qualified peer reviewers registered for article's evaluation, as listed in this issue.
\end{abstract}

Keywords: Ambi-Água; Qualis CAPES; ClusterMap ${ }^{\mathrm{TM}}$; journal indexing; environment and water.

\section{OVERVIEW OF JOURNAL VISIBILITY}

The Ambiente e Água Journal exercises the "golden open access" policy and search quality standard based on a large, highly qualified, peer review panel. The open access is powered by the OAI-PMH communication protocol as described in Batista (2007). Figure 1 shows in a weekly basis, the number of journal visits since we first started monitoring (September 10, 2007).

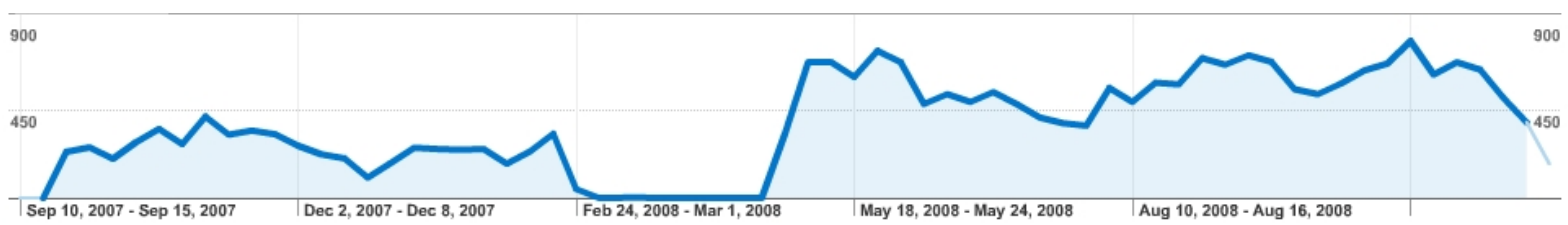

Figure 1. Number of journal's visitors per week since September 10, 2007 up to December 16, 2008. It increased from $\sim 300$ visitors per week in 2007 up to $\sim 700$ in 2008, with a peak of over 800 visitors in a single week. During this period there were 27,697 visits with 78,775 page views with an average time on site of 1:51 minutes.

To monitor reader's interest in the journal we started using a new tool from ClustrMaps $^{\mathrm{TM}}$ (Figure 2; Table 1). Figure 2 shows where visits came from in approximately one week time frame. 
BATISTA, G. T. Ambiente e Agua: un periódico en ascensión. Ambi-Agua, Taubaté, v. 3, n. 3, p. 15-19, 2008. (doi:10.4136/ambi-agua.57)

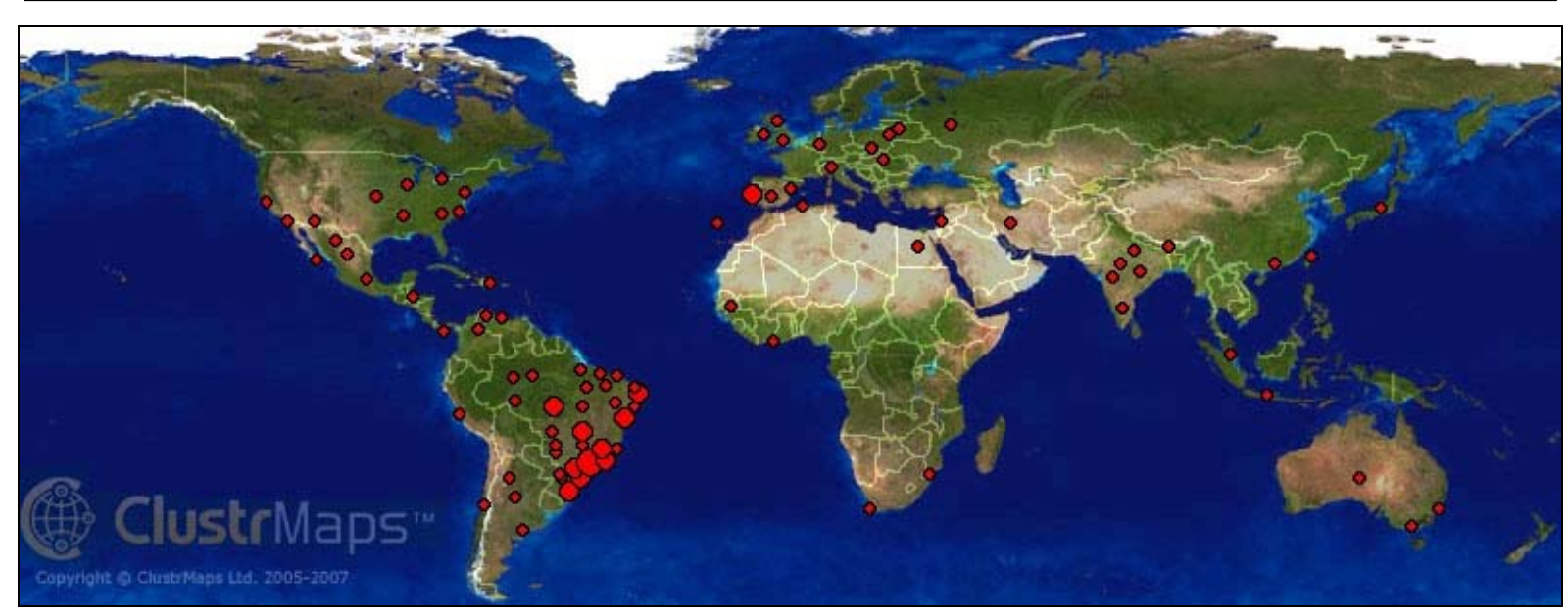

Figure 2. Location of visitors from December 8, 2008 to December 17, 2008. Dot sizes: $\mathrm{O}=100$ $999 \bigcirc=10-99 \odot=1-9$ visits from ClustrMaps ${ }^{\mathrm{TM}}$.

Table 1 shows the number of visits from countries that has accessed the journal in the same period shown in Figure 2.

Table 1. Frequency of access from countries where Ambi-Água has been accessed in the period from December 8, 2008 up to December 16, 2008.

\begin{tabular}{r|lr|r|lc}
\hline & \multicolumn{1}{|c|}{ Country } & $\mathbf{N}^{\mathbf{0}}$ & & \multicolumn{1}{c}{ Country } & $\mathbf{N}^{\mathbf{0}}$ \\
\hline 1 & Brazil (BR) & 392 & 22 & Netherlands (NL) & 1 \\
2 & United States (US) & 26 & 23 & Iran, Islamic Republic of (IR) & 1 \\
3 & Portugal (PT) & 24 & 24 & Belgium (BE) & 1 \\
4 & Spain (ES) & 10 & 25 & Algeria (DZ) & 1 \\
5 & Venezuela (VE) & 7 & 26 & China (CN) & 1 \\
6 & India (IN) & 7 & 27 & Singapore (SG) & 1 \\
7 & Mexico (MX) & 6 & 28 & Malaysia (MY) & 1 \\
8 & United Kingdom (GB) & 6 & 29 & Indonesia (ID) & 1 \\
9 & Japan (JP) & 5 & 30 & Mozambique (MZ) & 1 \\
10 & Australia (AU) & 4 & 31 & South Africa (ZA) & 1 \\
11 & Italy (IT) & 3 & 32 & Chile (CL) & 1 \\
12 & Canada (CA) & 3 & 33 & Cote D'Ivoire (CI) & 1 \\
13 & Peru (PE) & 3 & 34 & Panama (PA) & 1 \\
14 & Argentina (AR) & 3 & 35 & Taiwan (TW) & 1 \\
15 & Germany (DE) & 3 & 36 & Egypt (EG) & 1 \\
16 & Poland (PL) & 2 & 37 & Dominican Republic (DO) & 1 \\
17 & Lebanon (LB) & 1 & 38 & Honduras (HN) & 1 \\
18 & Hungary (HU) & 1 & 39 & Colombia (CO) & 1 \\
19 & Lithuania (LT) & 1 & 40 & Senegal (SN) & 1 \\
20 & Russian Federation (RU) & 1 & 41 & Israel (IL) & 1 \\
21 & Ireland (IE) & 1 & 42 & Netherlands (NL) & 1 \\
\hline
\end{tabular}

Source: ClustMaps $^{\mathrm{TM}}$ (http://www4.clustrmaps.com/counter/maps.php?url=http://www.agro.unitau. br/seer\&category=free).

Table 3 shows the regional origin of first authors. It can be noticed that Ambi-Água is raising interest of additional institutions since last reported by Batista (2007) from 18 institutions to 32 currently.

Table 3. Origin of first authors that already published in Ambi-Água (Volumes 1 (2006), 2 (2007) and 3 (2008)). 
BAtistA, G. T. Ambiente e Agua: un periódico en ascensión. Ambi-Agua, Taubaté, v. 3, n. 3, p. 15-19, 2008. (doi:10.4136/ambi-agua.57)

\begin{tabular}{|c|c|c|c|}
\hline & State/County & Institution & $\mathrm{N}^{0}$ Articles \\
\hline 1 & \multirow{12}{*}{ São Paulo/BR } & UNITAU & 12 \\
\hline 2 & & INPE & 9 \\
\hline 6 & & IG/SMA & 2 \\
\hline 3 & & CSA/CTA & 1 \\
\hline 4 & & UNESP/FEG & 1 \\
\hline 5 & & UNESP/Sorocaba & 1 \\
\hline 7 & & UFSCarlos & 1 \\
\hline 8 & & UNICAMP & 1 \\
\hline 9 & & EESC-USP & 1 \\
\hline 10 & & ESALQ-USP & 1 \\
\hline 11 & & POLI-USP & 1 \\
\hline 12 & & FF-SMA & 1 \\
\hline 13 & \multirow{4}{*}{ Minas Gerais/BR } & UFUberlândia & 2 \\
\hline 14 & & UFV & 2 \\
\hline 15 & & UFLA & 1 \\
\hline 16 & & UFOP & 1 \\
\hline 17 & \multirow{2}{*}{ Paraíba/BR } & UFPB & 3 \\
\hline 18 & & UFCGrande & 2 \\
\hline 19 & S. Catarina/BR & UFSC & 3 \\
\hline 20 & \multirow{2}{*}{ Paraná/BR } & UFPR & 2 \\
\hline 21 & & F. Assis Gurgaz & 1 \\
\hline 22 & Acre/BR & UFAcre & 2 \\
\hline 23 & \multirow{2}{*}{ Pará/BR } & SIVAM & 1 \\
\hline 24 & & UFPA & 1 \\
\hline 25 & Pernambuco/BR & UFPE & 1 \\
\hline 26 & R. G. do Sul/BR & UFPelotas & 1 \\
\hline 27 & R. de Janeiro/BR & PUC-RJ & 1 \\
\hline 28 & Cuba & Centro de Investigaciones Pesqueras & 1 \\
\hline 29 & MD/US & U. of Maryland & 1 \\
\hline 30 & Imo/Nigéria & F. University of Tecnology (Owerri)) & 1 \\
\hline 31 & Chaco/Argentina & Univ. Nacional del Nordeste & 1 \\
\hline 32 & Bangalore/India & College of Engineering & 1 \\
\hline
\end{tabular}

To increase the visibility of published articles, the journal is constantly looking for indexation of a scientific journal in several international directories (data harvesters; Table 2). In addition, the publication of articles in three optional languages (English, Portuguese and Spanish) and the presentation of an English version of all abstracts and keywords enlarge its impact. 
BATISTA, G. T. Ambiente e Agua: un periódico en ascensión. Ambi-Agua, Taubaté, v. 3, n. 3, p. 15-19, 2008. (doi:10.4136/ambi-agua.57)

Table 2. Directories that currently list the journal Ambi-Água.

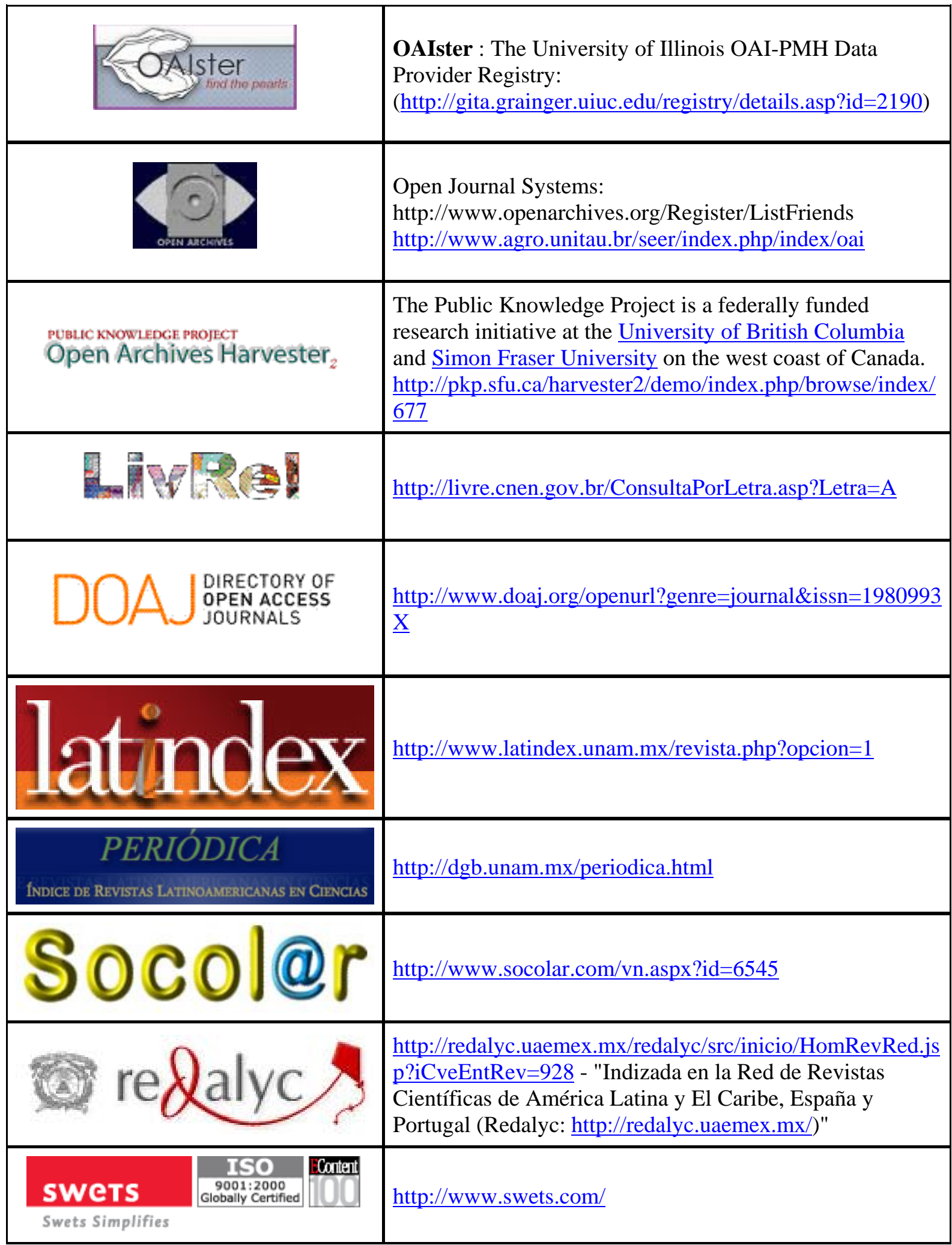

Note: Ambi-Água is registered in the Open Archives Initiative. The OAI URL of Ambi-Agua is: http://www.agro.unitau.br/seer/index.php/ambi-agua/oai?verb=Identify. At any moment Service Providers based on the OAI-PMH protocol can automatically index Ambi-Água and as a result enhance the visibility of the published articles. 


\section{FINAL REMARKS}

The Brazilian government agency, CAPES, responsible for the classification of journals concerned with accredited graduate degree courses normally would have already evaluated and classified Ambi-Água considering that it has published already three volumes and has several articles published by professors and students from the academic graduate system in Brazil. However, CAPES restructured its classification system and the committees related with Ambi-Água focus have not complete their evaluation in 2008. Therefore, we are waiting for the QUALIS CAPES classification.

\section{REFERENCES}

BATISTA, G. T. Geographical impact of scientific journals. Revista Ambi-Água, Taubaté, v. 2 , n. 3, p. 12-18, 2007.<http://www.agro.unitau.br/seer/index.php/ambiagua/article/view/85/123>. Acess Dec. 2008. 


ISSN = 1980-993X - doi:10.4136/1980-993X
www.agro.unitau.br/ambi-agua
E-mail: ambi-agua@agro.unitau.br
Tel.: (12) 3625-4116

\title{
Heterotrophic components of soil respiration in pastures and forests in southwestern Amazonia, Acre, Brazil \\ (doi:10.4136/ambi-agua.58)
}

\author{
Cleber Ibraim Salimon ${ }^{1}$; Eric Atlas Davidson ${ }^{2}$ \\ ${ }^{1}$ Universidade Federal do Acre, BR 364 km 4, CEP 69915-900 - Rio Branco, AC \\ E-mail: clebsal@gmail.com \\ ${ }^{2}$ The Woods Hole Research Center, 149 Woods Hole Road, Falmouth, MA \\ 02540-1644, USA \\ E-mail: edavidson@whrc.org
}

\begin{abstract}
In this paper we present data on soil microbial biomass and heterotrophic respiration in pastures, mature and secondary forests, in order to elucidate their contribution to total $\mathrm{CO}_{2}$ flux from soil to atmosphere. The research was conducted in Southwestern Amazonia, Acre State, Brazil. Microbial biomass was estimated using a variation of the traditional fumigationextraction method and heterotrophic respiration was measured using respirometry flasks attached to an infrared gas analyzer. Soil microbial biomass and heterotrophic respiration did not differ statistically among pastures, mature and secondary forests. These laboratory results indicate that higher $\mathrm{CO}_{2}$ fluxes from pasture soils measured in situ are probably due to higher root respiration by pasture grasses.
\end{abstract}

Keywords: soil microbial biomass; $\mathrm{CO}_{2}$ flux; heterotrophic respiration.

\section{Componentes heterotróficos da respiração em solos de pastagens e florestas na Amazônia Sul-Ocidental, Acre, Brasil}

\section{RESUMO}

No presente trabalho são apresentados dados sobre biomassa microbiana do solo e respiração heterotrófica em pastagens, florestas maduras e secundárias, no intuito de elucidar a sua contribuição para os fluxos totais de $\mathrm{CO}_{2}$ do solo para atmosfera. $\mathrm{O}$ trabalho foi realizado na Amazônia sul-ocidental, no estado do Acre. A biomassa microbiana foi estimada com base em uma variação do tradicional método de fumigação-extração e a respiração heterotrófica foi medida utilizando-se frascos para respirometria e um analisador de gás por infravermelho. Tanto biomassa microbiana do solo quanto respiração heterotrófica foram similares em pastagens e florestas. Com base nos resultados, concluiu-se que os maiores fluxos de $\mathrm{CO}_{2}$ do solo para a atmosfera, in situ, observados em pastagens, devem ser fruto da respiração radicular.

Palavras-chave: biomassa microbiana do solo; fluxo de $\mathrm{CO}_{2}$; respiração heterotrófica. 


\section{INTRODUCTION}

The flux of $\mathrm{CO}_{2}$ has been addressed in many studies in amazonian ecosystems in a variety of ways, from net ecosystem fluxes from tower measurements by eddy covariance techniques (Malhi et al., 1998; Miller et al., 2004), from soil to atmosphere (Salimon et al., 2004; Davidson and Trumbore, 1995; Sotta et al., 2004), to fluxes from rivers to the atmosphere (Richey et al., 2002).

One important aspect still to be elucidated in these multi level studies of $\mathrm{CO}_{2}$ flux in terrestrial ecosystems is the separation and quantification of autotrophic and heterotrophic respiration, because each of these components is important for understanding net ecosystem exchanges and balance (Chambers et al., 2004).

Land cover change is also another factor to be focused on, since the rate of soil respiration differs between pastures and forests in the Amazon, and it has been shown that in southwestern Amazonia, pastures increase $\mathrm{CO}_{2}$ flux from soil at the landscape scale since grasses present respiration rates that are higher than forests (Salimon et al., 2003).

Although separation of heterotrophic and autotrophic respiration is a very important issue (Millard et al., 2008) for the improvement of our understanding on the effects of land cover change on carbon fluxes and balances it is worth mentioning that to date it has not been addressed yet for the Amazon region.

Therefore, the main goal of this study was to determine if soil heterotrophic respiration follows the same pattern as total $\mathrm{CO}_{2}$ flux from soil to atmosphere in pastures and forests presented by Salimon et al. (2004). If heterotrophic respiration is equal to or less in pastures than in forests, then we can assume that the higher total flux in pastures is due to autotrophic respiration, because the total flux is the sum of hetero and autotrophic respiration.

For such purpose, we (1) determined the soil microbial biomass and (2) quantified heterotrophic soil respiration in pasture, secondary and mature forests.

\section{MATERIAL AND METHODS}

The present study was conducted in southwestern Amazonia, in the state of Acre, Brazil. Soils are predominantly ultisols and some patches of oxisols. Although both types of soils are mostly distrophyc, ultisols in Acre tend to be less poor in nutrients, with higher concentrations of $\mathrm{Ca}^{2+}$ and $\mathrm{Mg}^{2+}$ (Salimon et al., 2007). On the plateaus and upland the forest is classified as ombrophilous open forest, with patches of bamboo dominated areas and in the alluvial plains, where soils are usually gleysols, ombrophilous dense forest dominate the valleys with many palms. Mean annual temperature is $26^{\circ} \mathrm{C}$ and mean annual precipitation is $1940( \pm 228) \mathrm{mm}$ (Duarte, 2005).

The state has about $10 \%$ of its natural cover already deforested and the annual deforestation rate varies from 0.26 to $0.83 \%$ between 1977 and 2006 (INPE, 2007). The southwestern part of the state is the most deforested region, where more than $50 \%$ has already been deforested. Where the forest has been converted, $60 \%$ has turned into pasture for cattle ranching and subsistence agriculture and $40 \%$ is in some stage of secondary succession (Salimon et al., 2003).

Specifically, this study was conducted in two government sponsored settlements, (1) Peixoto Settlement Project and (2) Humaitá Settlement Project, hereafter referred to as Peixoto and Humaitá. In both settlements the main animal products are cattle and chickens and the principal crops are manioc, maize, banana, and rice. The typical land holding is about 120 ha located along access roads. A detailed description of each of the sampling sites is presented on Table 1. 
Soil microbial carbon biomass was estimated using an adaptation of the conventional fumigation and extraction method (Powson and Jenkinson, 1976; Feigl et al., 1995; Hanson et al., 2000). This alternative method, described below, was used due to laboratory and field conditions available in the Zoobotanical Park of the Federal University of Acre, Brazil. The main adaptations of the method were in relation to (1) methyl trichloride evaporation, which was carried out in a dry oven at $40^{\circ} \mathrm{C}$; and (2) carbon analysis which was carried out in an elemental analyzer.

Table 1. Sampling sites and their descriptions. Age of pastures and secondary forests refer to the year 2000. Names correspond to cover, where $\mathrm{P}$ - pasture, $\mathrm{C}$ - secondary forests and F - mature forests; numbers indicate the age of each pasture and secondary forest.

\begin{tabular}{|c|c|c|c|c|c|}
\hline \multirow{2}{*}{\multicolumn{2}{|c|}{ Sampling Site }} & \multicolumn{2}{|c|}{ Lat/Long } & \multirow{2}{*}{$\begin{array}{c}\text { Land cover and } \\
\text { age }\end{array}$} & \multirow{2}{*}{$\begin{array}{l}\text { Previous } \\
\text { cover }\end{array}$} \\
\hline & & $\mathrm{S}$ & $\mathrm{W}$ & & \\
\hline \multirow{3}{*}{ 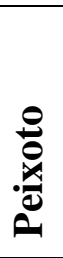 } & pasture13 & $9^{\circ} 52^{\prime} 27.6^{\prime \prime} \mathrm{S}$ & $67^{\circ} 4^{\prime} 19.2^{\prime \prime} \mathrm{W}$ & 13 year old pasture & $\begin{array}{l}\text { Mature } \\
\text { forest }\end{array}$ \\
\hline & secfor3a & $9^{\circ} 52^{\prime} 30.1 ' \prime \mathrm{S}$ & $67^{\circ} 4{ }^{\prime} 26.9^{\prime \prime} \mathrm{W}$ & $\begin{array}{l}\text { Three years old } \\
\text { secondary forest }\end{array}$ & $\begin{array}{l}\text { Manioc } \\
\text { plantation }\end{array}$ \\
\hline & matfora & $9^{\circ} 52^{\prime} 36.7^{\prime \prime} \mathrm{S}$ & $67^{\circ} 4{ }^{\prime} 37.9^{\prime \prime} \mathrm{W}$ & Mature forest & --- \\
\hline \multirow{3}{*}{ 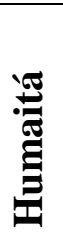 } & pasture14 & $9^{\circ} 46^{\prime} 12.8^{\prime \prime} \mathrm{S}$ & $67^{\circ} 39^{\prime} 28.7^{\prime \prime} \mathrm{W}$ & 14 year old pasture & $\begin{array}{l}\text { Mature } \\
\text { forest }\end{array}$ \\
\hline & secfor $3 b$ & $9^{\circ} 46^{\prime} 14.9$ '’ $\mathrm{S}$ & $67^{\circ} 39^{\prime} 27.9^{\prime \prime} \mathrm{W}$ & $\begin{array}{l}\text { Three years old } \\
\text { secondary forest }\end{array}$ & $\begin{array}{l}\text { Rice/beans } \\
\text { plantation }\end{array}$ \\
\hline & matforb & $9^{\circ} 46^{\prime} 13.5^{\prime \prime} \mathrm{S}$ & $67^{\circ} 39^{\prime} 29.1^{\prime \prime} \mathrm{W}$ & Mature forest & --- \\
\hline
\end{tabular}

Three soil samples were taken from each site in two depths $(0-5$ and 5-10 cm). Samples were taken to the lab and sieved through a $1 \mathrm{~mm}$ mesh size sieve. After a period of acclimation of three days in the dark at constant temperature of $25^{\circ} \mathrm{C}$ (Feigl et al., 1995), each sample was split into two sub-samples, one as control and the other for fumigation with methyl trichloride. From the control sub samples we extracted $15 \mathrm{~g}$ of soil which were placed in $100 \mathrm{ml}$ flasks and then mixed with $75 \mathrm{ml}$ of a $\mathrm{K}_{2} \mathrm{SO}_{4} 0.5 \mathrm{M}$ solution, for the soluble soil carbon extraction. After addition of this solution, each sample flask was agitated vigorously for two minutes and then settled for $24 \mathrm{~h}$ at $25^{\circ} \mathrm{C}$. After this period, samples were sieved in a fiber glass filter $(0.7 \mu \mathrm{m}$ nominal porosity) and the filtered solution was frozen for later carbon analysis.

For the fumigated sub-samples, $15 \mathrm{~g}$ of soil were placed in $100 \mathrm{ml}$ flask together with 4 $\mathrm{ml}$ of pure methyl trichloride, and left with its lid closed for $48 \mathrm{~h}$ at $25^{\circ} \mathrm{C}$, after which the flasks were open and left in a dry oven at $40^{\circ} \mathrm{C}$ for five hours until complete methyl trichloride evaporation. After this procedure $75 \mathrm{ml}$ of $\mathrm{K}_{2} \mathrm{SO}_{4}$ 0,5 $\mathrm{M}$ were added to the soil and then all the process described for the control sub-samples were repeated.

The frozen sub-samples were taken to the Isotopic Ecology Laboratory of the Center of Nuclear Energy to Agriculture (CENA) at the University of São Paulo, where they were defrosted and subsequently dehydrated at constant temperature of $50^{\circ} \mathrm{C}$ for 72 hours in a dry oven. The resultant salt, which contained the soluble carbon extracted from the soil was then taken to an Element Analyzer Carlo Erba 1110 CNHS.

Microbial biomass was estimated by using the $\mathrm{C}$ concentration of the fumigated and the control soil samples, using a correction factor for $\mathrm{C}$ content in microbial biomass ( $\mathrm{k}$ factor) proposed by Feigl et al. (1995), who have determined a specific value for tropical soils. 
One way of separating $\mathrm{CO}_{2}$ flux into heterotrophic and autotrophic components is by in vitro respirometry essays, where the live plant material is extracted from the soil, so that the flux values measured will be resultant only from the heterotrophic respiration. This methodology serves for semi-quantitative comparisons with in situ data, where autotrophic respiration is included as well. Salimon et al. (2004) showed that higher total $\mathrm{CO}_{2}$ fluxes from soil were observed in pastures and not in forests based on in situ data from the exact same sites of the present study. A fully quantitative comparison cannot be possible since the quantity of soil involved and environmental conditions (such as soil bulk density, aeration, temperature, among others) are distinct for each method. Nonetheless, with such approach, we can conjecture about the importance of the heterotrophic and autotrophic components of soil respiration and therefore, contribute to the understanding of the effects of land cover change on the carbon cycling in the Amazon.

In vitro heterotrophic respiration was measured with a respirometer (a $600 \mathrm{ml}$ glass bottle with two stopcocks, attached to tubings which were connected to an infrared gas analyzer (IRGA - LICOR-6252). The IRGA was calibrated every morning by using 'zero' air that had been run through a soda lime scrubber and by using a White Martins certificated standard gas of $610( \pm 2 \%)$ ppmv of $\mathrm{CO}_{2}$ (nitrogen as balance gas).

At each land cover type (pasture, secondary and mature forest) five soil samples were taken from 0-5 cm depth. Each sample was sieved ( $1 \mathrm{~mm}$ mesh) for root extraction and then it was homogenized and left at constant temperature of $25^{\circ} \mathrm{C}$ for three days for acclimation of all samples and treatments (land cover type). After acclimation $20 \mathrm{~g}$ of soil from each sample were placed inside a respirometer (five replicates for each land cover type). The respirometer was then closed and the increase in $\mathrm{CO}_{2}$ concentration was recorded with the IRGA every hour for 12 hours.

With the $\mathrm{CO}_{2}$ concentration data, we then made regressions with time to estimate the fluxes, taking into account the volume of the respirometer and tubings, gas constants and temperature. This heterotrophic respiration essay was carried out in four occasions: November 2001, March 2002, April 2002 and July 2002, in order to identify if there was any change throughout the seasons.

We took sub-samples from each soil sample for the heterotrophic respiration in order to estimate volumetric water content, by oven-drying these sub-samples at $110^{\circ} \mathrm{C}$ for 72 hours.

Statistical analyses were carried out using non parametric tests, since our data did not fit into a normal distribution, neither presented homogeneity of variances (Sokal and Rohlf, 1995).

\section{RESULTS AND DISCUSSION}

The results for soil microbial biomass estimation for pasture, secondary and mature forest are presented on Table 2 .

The highest observed value for $\mathrm{C}$ content was for a secondary forest $(156 \pm 26 \mu \mathrm{g} \mathrm{C} \mathrm{g}$ soil $\left.^{-1}\right)$ and the lowest was for a mature forest $\left(65 \pm 55 \mu \mathrm{g} \mathrm{C} \mathrm{g} \mathrm{soil}{ }^{-1}\right)$. With the exception of one secondary forest $(\mathrm{C} 3 \mathrm{~B})$, all sampled sites presented higher microbial biomass between 0 and $5 \mathrm{~cm}$ depth.

Both pasture and forests (mature and secondary) presented similar values for C content in the soil microbial biomass and the differences were not statistically significant $(p>0.05-$ Kruskal-Wallis test).

A comparison of these results with data from other authors should be taken carefully since biomass estimation in the present study was made using an alternative method that is different from the ones used in the current literature. For instance, the numbers presented here 
are much lower than the ones presented by Feigl et al. (1995) for other site in Amazonia, with values ranging from 390 to $580 \mu \mathrm{g} \mathrm{C} \mathrm{g} \mathrm{soil}{ }^{-1}$.

Although there is no direct relationship between soil microbial biomass and heterotrophic respiration, the similarity of values presented among pasture, secondary and mature forests can be considered as an indicative of similar rates of heterotrophic respiration, which was indeed observed and described hereafter.

Table 2. Microbial biomass in pastures, secondary and mature forests; values in parenthesis are for standard deviation $(n=3)$.

Numbers in the acronyms of each site correspond to the age of the land cover.

\begin{tabular}{llrc}
\hline & & \multicolumn{2}{c}{$\begin{array}{c}\text { Microbial Biomass } \\
\left(\mu \mathbf{g ~ C} \text { g soil }^{-\mathbf{1}}\right)\end{array}$} \\
& Sampling site & 0-5 cm & $\mathbf{1 0 - 2 0 ~ c m}$ \\
\hline Peixoto & Secfor3a & $156(26)$ & $52(52)$ \\
& matfora & $65(55)$ & $26(37)$ \\
& pasture 13 & $147(75)$ & $95(54)$ \\
Humaitá & Secfor3b & $69(15)$ & $69(15)$ \\
& matforb & $95(40)$ & $35(15)$ \\
& pasture14 & $69(30)$ & $35(40)$ \\
\hline
\end{tabular}

Soil volumetric water content of samples, varied from 13 to $36 \%$ (Table 3 ), where pastures always presented higher values than forests ( $\mathrm{p}<0.05$ - Kruskal-Wallis test), except for the April 2002 essay. The higher water content in pasture soils does not mean necessarily more available water to microbes or roots, since pastures also present higher clay content probably due to more intense erosion processes (Salimon et al., 2007). Such higher clay content, although retaining more water, makes it harder to be extracted by organisms due to capillary forces in the mineral particles.

Table 3. Soil volumetric water content (\%) in each of the Peixoto sampling sites for the respirometry essays $(n=4)$. Numbers in the acronyms of each site correspond to the age of the land cover.

\begin{tabular}{lcccc}
\hline & Nov/01 & Mar/02 & Apr/02 & Jul/02 \\
\hline Secfor3a & $15.0(1.4)$ & $14.4(1.1)$ & $29.8(2.2)$ & $18.7(0.4)$ \\
matfora & $16.4(1.0)$ & $13.5(1.9)$ & $28.8(1.6)$ & $19.6(0.4)$ \\
Pasture13 & $19.9(1.7)$ & $19.9(2.3)$ & $35.4(4.4)$ & $23.1(0.5)$ \\
\hline
\end{tabular}

No clear trend was observed among treatments or in the seasons, although the highest values for all treatments were observed in July 2002 (Table 4 and Figure 1)

In November 2001 the mature forest presented the highest respiration, followed by the secondary forest and the lowest value was observed for the pasture. In March 2002 the highest respiration was observed in the pasture samples, followed by secondary and mature forests, respectively. In April 2002, secondary forest samples presented the highest values, and in July 2002, mature forest samples again presented the highest values. 
Table 4. In vitro heterotrophic respiration for the Peixoto sites (southeast of the state of Acre). Values in $\mu \mathrm{g} \mathrm{C} \mathrm{g} \operatorname{soil}^{-1} \mathrm{~h}^{-1}$; standard deviation in parenthesis $(\mathrm{n}=5)$.

\begin{tabular}{l|ccc}
\hline & Secondary forest & Mature forest & Pasture \\
\hline November 2001 & $0.58(0.1)$ & $0.79(0.1)$ & $0.47(0.1)$ \\
March 2002 & $0.74(0.1)$ & $0.66(0.2)$ & $0.97(0.3)$ \\
April 2002 & $0.34(0.0)$ & $0.65(0.2)$ & $0.54(0.2)$ \\
July 2002 & $1.69(0.2)$ & $1.91(0.5)$ & $1.69(0.3)$ \\
\hline
\end{tabular}

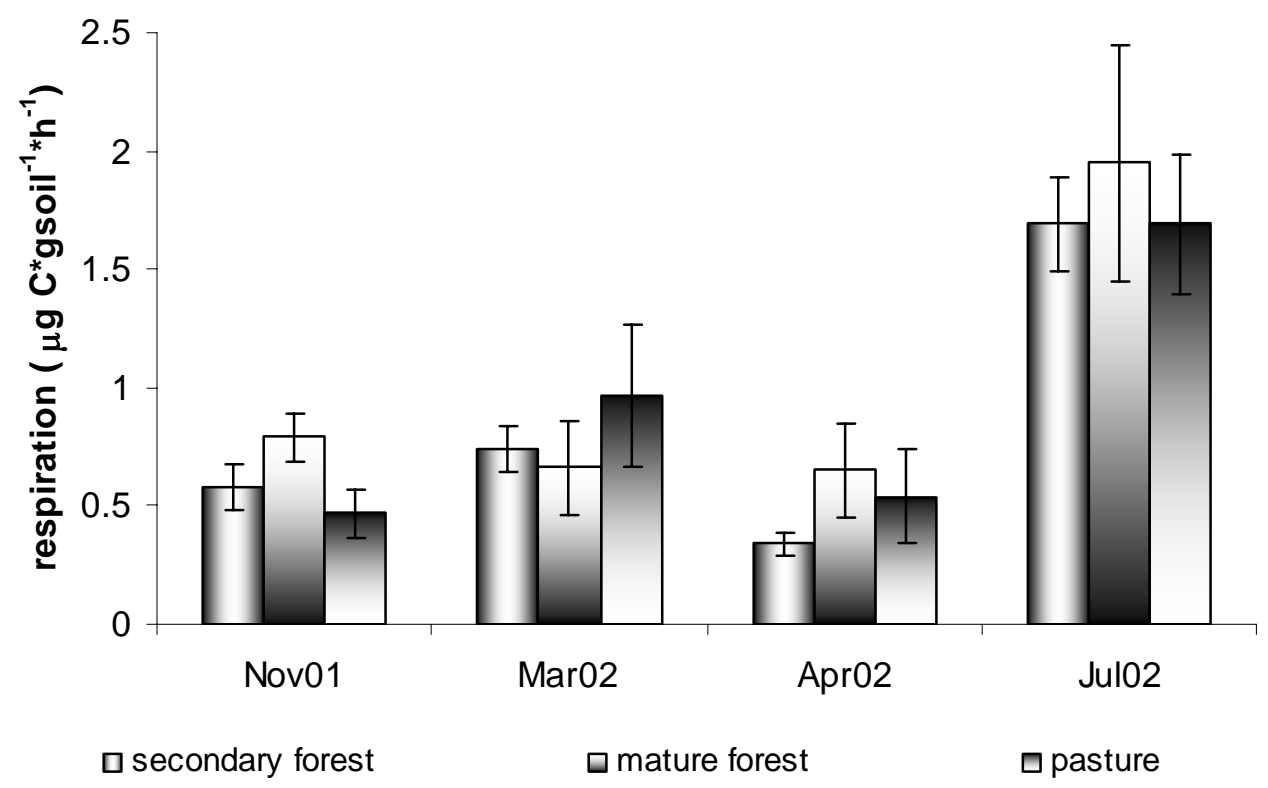

Figure 1. In vitro heterotrophic respiration in secondary forest, mature forest and pasture at the Peixoto study area (southeast of the state of Acre).

When statistically comparing treatments (Kruskal-Wallis, $\mathrm{p}>0.05$; and Multiple Comparison of Mean Ranks tests, $\mathrm{p}>0.05$ ) in each of the four essays, we observe that in November 2001, mature and secondary forests presented similar respiration rates, but significantly higher than pasture. In March 2002 only pasture and mature forest were significantly different, while in April and July 2002 there was no significant difference among treatments. Based on these statistical results, we did not observe any pattern suggesting that any of the land cover types studied present significant differences in heterotrophical respiration

Contrary to these findings, Salimon et al. (2004) showed that pastures presented greater $\mathrm{CO}_{2}$ from soil than mature and secondary forests. If heterotrophic respiration rates are not consistently different among treatments, but total $\mathrm{CO}_{2}$ flux in situ is higher in pastures, then autotrophic respiration could be the most probable cause for higher total fluxes in pasture soils. Grasses in these productive pastures could be allocating part of its carbon bellow ground, supporting the high root respiration rates.

Although the values presented here cannot be quantitatively used for estimating the exact percent contribution of autotrophic and heterotrophic respiration in total $\mathrm{CO}_{2}$ flux from soil, we can infer that autotrophic contribution is higher, since with the removal of roots from the soil, pasture's respiration (in vitro) is not different than in forests.

Also, Salimon et al. (2004) showed that the $\delta^{13} \mathrm{C}$ of total respired $\mathrm{CO}_{2}$ in the pasture soil was $-14 \%$, which is very close to $-13 \%$ of the Brachiaria brizantha dominant grass in these pastures, suggesting that most of the carbon released during respiration has a $\mathrm{C} 4$ plant 

southwestern Amazonia, Acre, Brazil. Ambi-Agua, Taubaté, v. 3, n. 3, p. 20-27, 2008. (doi:10.4136/ambiagua.58)

signature, which comes from the pasture's grasses. This finding also corroborates with our results here.

\section{CONCLUSION}

Even from the semi-quantitative results presented here and based on unusual techniques, we suggest that root respiration is the largest component responsible for the higher total in situ $\mathrm{CO}_{2}$ fluxes from soil in pastures, since both soil microbial biomass and soil heterotrophic respiration did not differ significantly between pasture and forests.

\section{ACKNOWLEDGEMENTS}

We would like to thank Reynaldo Luiz Victoria and Susan Trumbore for valued discussions; Antonio Willian Flores de Melo and Jorcinei W. Pereira for field and lab work. This research was funded by FAPESP process 99/03315-3 and NASA LBA-ECO grants NCC5-332, NCC5-686, and NNG06GE88A.

\section{REFERENCES}

ACRE. Zoneamento ecológico-econômico do estado do Acre. Rio Branco: Governo do Estado do Acre, 2000.

CHAMBERS, J. Q.; TRIBUZY, E. S.; TOLEDO, L. C.; CRISPIM, B. F.; HIGUCHI, N.; DOS SANTOS, J., et al. Respiration from a tropical forest ecosystem: partitioning of sources and low carbon use efficiency. Ecological Applications, v. 14, n. 4, p. S72S88, Supplement, 2004.

DAVIDSON, E. A.; TRUMBORE, S. E. Gas diffusivity and production of $\mathrm{CO}_{2}$ in deep soils of the eastern Amazonia. Tellus, v. 4, n. 47B, p.550-565, 1995.

DUARTE, A. F. Variabilidade e tendência das chuvas em Rio Branco, Acre, Brasil. Revista Brasileira de Meteorologia, v. 20, n. 1, p. 37-42, 2005.

FEIGL, B. J.; SPARLING, G. G.; ROSS, D. J.; CERRI, C. C. Soil microbial biomass in Amazonian soils: evaluation of methods and estimates of pool sizes. Soil Biology and Biochemistry, v. 27, n. 11, p. 1467-1472, 1995.

HANSON, P. J.; EDWARDS, N. T.; GARTEN, C. T.; ANDREWS, J. A. Separating root and soil microbial contributions to soil respiration: a review of methods and observations. Biogeochemistry, v. 48, p. 115-146, 2000.

INSTITUTO NACIONAL DE PESQUISAS ESPACIAIS. Monitoramento da floresta amazônica por satélite, Projeto PRODES. São José dos Campos: INPE, 2007. Disponível em: <http://www.obt.inpe.br/prodes/>. Acesso em: nov. 2007.

MALHI, Y.; NOBRE, A. D.; GRACE, J.; KRUIJT, B.; PEREIRA, M. G. P.; CULF, A., et al. Carbon dioxide transfer over a Central Amazonian rain forest. Journal of Geophysical Research-Atmospheres, v. 103, p. 31593-31612, 1998.

MILLARD, P.; MIDWOOD, A. J.; HUNT, J. E.; WHITEHEAD, D.; BOUTTON, T. W. Partitioning soil surface $\mathrm{CO} 2$ efflux into autotrophic and heterotrophic components, 
using natural gradients in soil delta C-13 in an undisturbed savannah soil. Soil Biology \& Biochemistry, v. 40, n. 7, p. 1575-582, 2008.

MILLER, S. M.; GOULDEN, M. L.; MENTON, M. C.; ROCHA, H. R.; FREITAS, H. C.; FIGUEIRA, A. M. S., et al. Biometric and micrometeorological measurements of tropical Forest carbon balance. Ecological Monographs, v. 14, n. 4, p. S114-S126, supplement, 2004.

PETRI, S.; FULFARO, V. J. Geologia do Brasil. São Paulo: EDUSP, 1988. 631p,

POWLSON, D. S.; JENKINSON, D. S. The effects of biocidal treatments on metabolism in soil - II. Gamma irradiation, autoclaving, air-drying and fumigation. Soil Biology and Biochemistry, v. 8, p. 179-188, 1976.

RICHEY, J. E.; MELACK, J. M.; AUFDENKAMPE, A. K.; BALLESTER, V. M.; HESS, L. L. Outgassing from Amazonian rivers and wetlands as a large tropical source of atmospheric $\mathrm{CO}_{2}$. Nature, v. 416, p. 617-620, 2002.

SALIMON, C. I.; VICTORIA R. L.; BROWN, I. F.; STONE, T. A.; DAVIDSON, E. A. Mudança de Cobertura da Terra e Fluxo de $\mathrm{CO}_{2}$ do solo para atmosfera na Amazônia Sul-ocidental. In: SEMINÁRIO BRASILEIRO DE SENSORIAMENTO REMOTO, 11, 2003, Belo Horizonte. Anais... São José dos Campos: INPE, 2003. p. 699-705.

SALIMON, C. I.; DAVIDSON, E. A.; VICTORIA, R. L.; MELO, A. W. F. $\mathrm{CO}_{2}$ flux from soil in pastures and forests in southwestern Amazonia. Global Change Biology, v. 10, n. 5 , p. $833-843,2004$.

SALIMON, C. I.; WADT, P.; MELO, A. W. F. Dinâmica do Carbono na conversão de floresta para pastagens em argissolos da formação geológica solimões, no sudoeste da Amazônia. Revista de Biologia e Ciências da Terra, v. 7, p. 29 - 38, 2007.

SOKAL, R. R.; ROHLF, F. J. Biometry. New York: W. H. Freeman and company, 1995.

SOTTA, E. D.; MEIR, P.; MALHI, Y.; NOBRE, A. D.; HODNETT, M.; GRACE, J. Soil CO efflux in a tropical forest in the central Amazon. Global Change Biology, v. 10, n. 5, p. 601-617, 2004. 


\begin{tabular}{ccc|} 
ISSN = 1980-993X - doi:10.4136/1980-993X \\
www.agro.unitau.br/ambi-agua \\
E-mail: ambi-agua@agro.unitau.br \\
Tel.: (12) 3625-4116
\end{tabular}

\title{
Water deficit and water surplus maps for Brazil, based on FAO Penman-Monteith potential evapotranspiration (doi:10.4136/ambi-agua.59)
}

\author{
Paulo C. Sentelhas ${ }^{1}$; Dayana L. dos Santos²; Ronalton E. Machado ${ }^{3}$ \\ ${ }^{1}$ Departamento de Ciências Exatas, ESALQ/USP - Caixa Postal 9, 13418-900, Piracicaba, SP, Brasil \\ E-mail: pcsentel@esalq.usp.br; Bolsista do CNPq \\ ${ }^{2}$ Aluna do curso de Engenharia Agronômica - ESALQ/USP \\ E-mail: dlsantos@esalq.usp.br \\ ${ }^{3}$ Departamento de Engenharia Ambiental, Escola de Engenharia de Piracicaba, FUMEP \\ E-mail: remachad@yahoo.com.br
}

\begin{abstract}
The climatological water balance (CWB) proposed by Thornthwaite and Mather (1957) is a useful tool for agricultural planning. This method requires the soil water holding capacity (SWHC), rainfall (R) and potential evapotranspiration (PET) data as input. Among the methods used to estimate PET, the one proposed by Thornthwaite (1948) is the simplest and the most used in Brazil, however it presents limitations of use, which is caused by its empirical relationships. When Thornthwaite PET method is used into the CWB, the errors associated to PET are transferred to the output variables, mainly water deficit (WD) and water surplus (WS). As all maps of WD and WS for Brazil are based on Thornthwaite PET, the objective of this study was to produce new maps of these variables considering PenmanMonteith PET. For this purpose, monthly normal climate data base (1961-1990) from Brazilian Meteorological Service (INMET), with 219 locations in all country, was used. PET data were estimated by Thornthwaite (TH) and FAO Penman-Monteith (PM) methods. PET, from both methods, and R data were used to estimate the CWB for a SWHC of $100 \mathrm{~mm}$, having as results actual ET (AET), WD and WS. Results obtained with PET from the two methods were compared by regression analysis. The results showed that $\mathrm{TH}$ method underestimated annual PM PET by $13 \%$ in $84 \%$ of the places. Such underestimation also led to AET and WD underestimations of $7 \%$ (in $69 \%$ of places) and $40 \%$ (in $83 \%$ of places), respectively. For WS, the use of TH PET data in the CWB resulted in overestimations of about $80 \%$ in $78 \%$ of places. The differences observed in the CWB variables resulted in changes in the maps of WD and WS for Brazil. These new maps, based on PM PET, provide more accurate information, mainly for agricultural and hydrological planning and irrigation and drainage projects purposes.
\end{abstract}

Keywords: climatological water balance; agricultural planning; irrigation projects.

\section{Mapas de deficiência hídrica e excedente hídrico para o Brasil, baseados na evapotranspiração potencial de Penman-Monteith - FAO}

\section{RESUMO}

O balanço hídrico climatológico (BHC) proposto por Thornthwaite e Mather (1957) é uma ferramenta muito útil para o planejamento agrícola. Esse método requer como variáveis de entrada a capacidade de água disponível do solo (CAD), a chuva (P) e a evapotranspiração 
potencial (ETP). A chuva é uma variável facilmente mensurável e a CAD pode ser determinada de forma relativamente simples conhecendo-se as características físicas do solo. No entanto, a ETP necessita ser estimada com base em dados meteorológicos. Dentre os métodos utilizados para a estimativa da ETP, o proposto por Thornthwaite (1948) é o mais simples e o mais empregado no Brasil, exigindo apenas dados de temperatura. Entretanto, esse método apresenta limitações de uso, já que se baseia apenas em relações empíricas. Quando o BHC é estimado com a ETP calculada pelo método de Thornthwaite, os erros dessa variável são transferidos para as outras variáveis, especialmente para a DEF e o EXC. Como todos os mapas de DEF e EXC para o Brasil são baseados nos dados estimados com a ETP de Thornthwaite, o objetivo deste trabalho foi gerar novos mapas dessas variáveis considerandose a ETP estimada pelo método Penman-Monteith, o qual é o método de referência adotado pela FAO. Para tanto, foram utilizados dados climáticos normais (1961-1990) do Instituto Nacional de Meteorologia (INMET), com 219 localidades em todo o país. Esses dados foram empregados na estimativa da ETP pelos métodos de Thornthwaite - TH e FAO PenmanMonteith - PM. Dados da ETP, estimada por ambos os métodos, e de chuva, foram usados para a estimativa do BHC para uma CAD de $100 \mathrm{~mm}$, tendo como variáveis resultantes a evapotranspiração real (ETR), DEF e EXC, que foram comparadas por análise de regressão. Os resultados mostraram que o método de TH subestimou a ETP anual, em relação ao método de PM, em 13\% em $84 \%$ das localidades. Tal subestimativa levou a subestimativas também da ETR e da DEF, respectivamente de 7\% (em 69\% dos locais) e $40 \%$ (em $83 \%$ dos locais). Para o EXC, o uso da ETP de TH resultou em superestimativas médias da ordem de $80 \%$ em $78 \%$ dos locais analisados. As diferenças observadas nas variáveis do BHC quando a ETP foi estimada por diferentes métodos resultou em mudanças substanciais nos mapas de DEF e EXC para o Brasil. Esses novos mapas, baseados na ETP estimada pelo método de PM, fornecem informações mais acuradas, especialmente para fins de planejamento agrícola e hidrológico e para projetos de irrigação.

Palavras-chave: balanço hídrico climatológico; planejamento agrícola; projetos de irrigação.

\section{INTRODUCTION}

The climatological water balance (CWB) proposed by Thornthwaite and Mather (1955, 1957) is a useful tool for agricultural planning, being used as a method to determine soil water storage (SWS), actual evapotranspiration (AET), water deficit (WD) and water surplus (WS) in a regional level. SWS is a function of the soil type and water balance (Rain Evapotranspiration). AET is the evapotranspiration from a surface covered with short grass, controlled by weather conditions and current available soil water. This variable is equal or smaller than potential evapotranspiration (PET), which is controlled only by climatic variables. WD represents the water that the plant surface did not use during the period, in function of the shortage of water in the soil. By definition, WD is calculated by the difference between PET and AET. Finally, WS is the amount of water not retained by the soil when rainfall is greater than PET and soil moisture is at the field capacity. This surplus will be drained, recharging the water table.

Originally, CWB was proposed by Thornthwaite to rationalize the climatic classification, but with time its use in agriculture increased, mainly for agricultural planning purposes, like agroclimatic zoning and irrigation demand projects (Pereira et al., 2002a; Black, 2007).

Thornthwaite and Mather $(1955,1957)$ method requires the soil water holding capacity (SWHC), rainfall (R) and potential evapotranspiration (PET) data as input. Rainfall is an easy 
measurable variable and SWHC can be determined knowing physical soil properties, but normally ranges from 50 to $300 \mathrm{~mm}$, depending on the soil type and depth. On the other hand, PET, which represents the amount of water evaporated and transpired in a given time by a short grass crop, completely shading the ground, of uniform height and with adequate water status in the soil profile (Camargo and Camargo, 2000), must be estimated from standard weather data. Among the several methods used to estimate PET, the one proposed by Thornthwaite (1948) and revised by Thornthwaite and Mather $(1955,1957)$ is the simplest and the most used in Brazil, since it just requires temperature data (Camargo, 1962; Camargo, 1978; Camargo and Camargo, 2000; Pereira et al., 2002a). However, this method presents limitations of use, which is related with its empirical relationships, underestimating PET in dry climates and overestimating it in super-humid conditions (Hashemi and Habibian, 1979; Camargo and Sentelhas, 1997; Camargo et al., 1999). When Thornthwaite's PET method is used in the CWB, the errors associated to PET estimates are expected to be transferred to the other variables, mainly WD and WS, important parameters for agroclimatic crop zoning.

The used of more accurate PET methods are normally limited by the availability of weather data (Pereira et al., 2002a). Where a complete weather data set is available, the best way to estimate PET is by Penman-Monteith method, which is recognized by the scientific community and FAO - Irrigation and Drainage expert team as the most precise and accurate (Allen et al., 1998). This method is universal, it can be calculated in different time intervals (Back, 2007) and presents a high performance in a wide range of climatic conditions, as reported by Allen (1986), Allen et al. (1989), Pereira (1998), Sentelhas (1998), Pereira et al. (2002b), and Medeiros et al. (2003), not requiring calibration or adjustments.

The objectives of this study was to compare monthly PET estimated by Thornthwaite and Penman-Monteith methods, and to produce new maps of these variables based on PET estimated by FAO Penman-Monteith method.

\section{MATERIAL AND METHODS}

Monthly normal climate data (air temperature and relative humidity, hours of sunshine, and rainfall) for the period of 1961-1990, from the Brazilian Meteorological Service (Instituto Nacional de Meteorologia - INMET), with 219 locations in all country (Figure 1), were used do estimate potential evapotranspiration (PET) and climatological water balance (CWB).

PET was estimated by Thornthwaite (TH) and FAO Penman-Monteith (PM) methods. $\mathrm{TH}$ method has air temperature as its only variable and is determined by the following equations (Pereira et al., 2002a):

$$
\begin{array}{ll}
E T p=16 *(10 * \mathrm{Tm} / \mathrm{I})^{\mathrm{a}} & \text { for } 0 \leq \mathrm{Tm}<26.5^{\circ} \mathrm{C} \\
E T p=-415.85+32.24 * \mathrm{Tm}-0.43 * \mathrm{Tm}^{2} \quad \text { for } \mathrm{Tm} \geq 26.5^{\circ} \mathrm{C} \\
I=12 *(0.2 * \mathrm{Ta})^{1,514} & \\
a=0.49239+1.7912 * 10^{-2} * \mathrm{I}-7.71 * 10^{-5} * \mathrm{I}^{2}+6.75^{*} 10^{-7} * \mathrm{I}^{3}
\end{array}
$$

where: ETp is a standard evapotranspiration for a month of 30 days and with daylight period of $12 \mathrm{~h}$; Tm the monthly temperature; $I$ and $a$ thermal indexes, function of annual average temperature (Ta). ETP, in mm per month, will be obtained by:

$$
\begin{aligned}
& \mathrm{ETP}=\mathrm{ETp} * f c \\
& f c=\mathrm{N} / 12 * \mathrm{NDM} / 30
\end{aligned}
$$


where: $\mathrm{N}$ is the daylight period of the current month and NDM the number of days of the month.

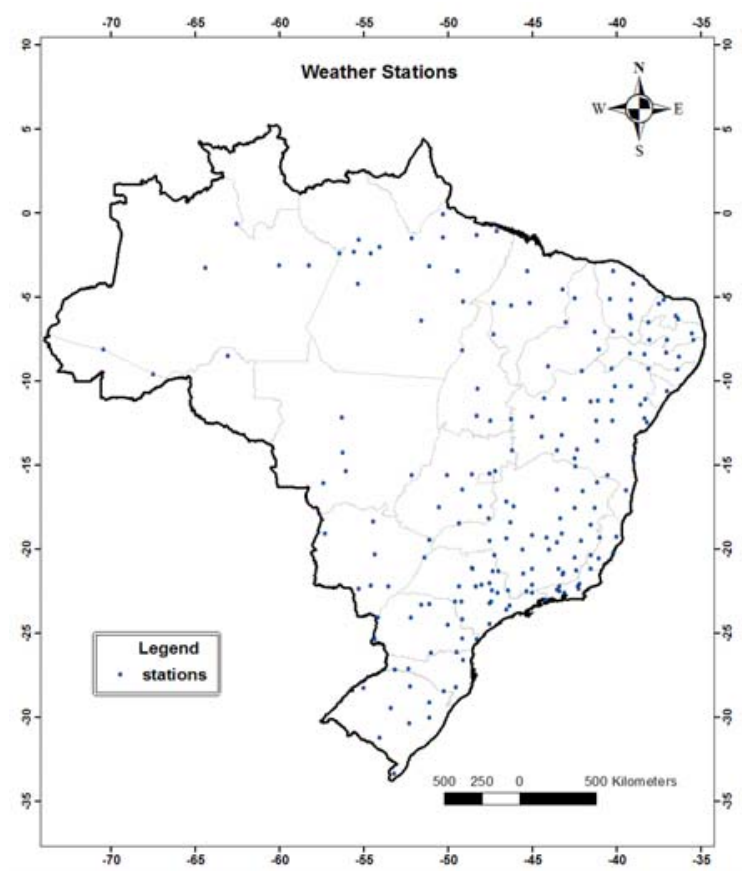

Figure 1. Localization of the weather stations used in the present study.

Penman-Monteith method is known as FAO reference method to estimate PET (Allen et al., 1998). This method considers all weather parameters as variables and is given by the following equation:

$$
\mathrm{ETP}=\left\{\left[0.408 * \mathrm{~s} *(\mathrm{Rn}-\mathrm{G})+\left(\gamma * 900 * \mathrm{U}_{2 \mathrm{~m}} * \Delta \mathrm{e}\right) /(\mathrm{T}+273)\right] /\left[\mathrm{s}+\gamma *\left(1+0.34 * \mathrm{U}_{2 \mathrm{~m}}\right)\right]\right\} * \mathrm{NDM}[7]
$$

where: $\mathrm{Rn}$ is net radiation at the crop surface $\left[\mathrm{MJ} \mathrm{m}^{-2}\right.$ day $\left.^{-1}\right]$; $\mathrm{G}$ soil heat flux density $\left[\mathrm{MJ} \mathrm{m}^{-2}\right.$ day $\left.^{-1}\right]$; $\mathrm{T}$ mean air temperature at $2 \mathrm{~m}$ height $\left[{ }^{\circ} \mathrm{C}\right] ; \gamma$ psychrometric constant $\left[\mathrm{kPa}{ }^{\circ} \mathrm{C}^{-1}\right] ; \mathrm{U}_{2 \mathrm{~m}}$ wind speed at $2 \mathrm{~m}$ height $\left[\mathrm{m} \mathrm{s}^{-1}\right] ; \Delta \mathrm{e}$ saturation vapor pressure deficit $[\mathrm{kPa}]$; s slope vapor pressure curve $\left[\mathrm{kPa}^{\circ} \mathrm{C}^{-1}\right]$, being calculated by:

$$
\mathrm{s}=(4098 * \mathrm{es}) /(237.3+\mathrm{T})^{2}
$$

where:

$$
\begin{aligned}
& \text { es }=\left(\mathrm{es}^{\mathrm{Tmax}}+\mathrm{es}^{\mathrm{Tmin}}\right) / 2 \\
& \text { es }^{\mathrm{Tmax}}=0.611 * \operatorname{EXP}[(17.27 * \text { Tmax }) /(237.3+\mathrm{Tmax})] \\
& \text { es }^{\mathrm{T} \min }=0.611 * \operatorname{EXP}[(17.27 * \mathrm{Tmin}) /(237.3+\mathrm{Tmin})] \\
& \text { ea }=(\mathrm{URmed} * \mathrm{es}) / 100 \\
& \mathrm{~T}=(\mathrm{Tmax}+\mathrm{Tmin}) / 2
\end{aligned}
$$

$\mathrm{Rn}$ was estimated by equation 14, as a function of short and long wave radiation balances, whereas $\mathrm{G}$ was assumed to be null.

$$
\mathrm{Rn}=0.77 *[\mathrm{Qo} *(\mathrm{a}+\mathrm{b} * \mathrm{n} / \mathrm{N})]-\sigma^{*} \mathrm{~T}_{\mathrm{k}}{ }^{4} *\left(0.56-0.24 * \mathrm{ea}^{0.5}\right) *(0.1+0.9 * \mathrm{n} / \mathrm{N})
$$


where: $\mathrm{a}=0.29 * \cos \varnothing[\varnothing=$ latitude $] ; \mathrm{b}=0.52 ; \mathrm{n}=$ effective hours of sunshine; $\sigma=$ $4,8989 \cdot 10^{-9} \mathrm{MJ} \cdot \mathrm{m}^{-2} \cdot \mathrm{d}^{-1} \cdot \mathrm{K}^{-4}$.

As no wind data were available for all places at the INMET database, the normal wind speed data for estimating Penman-Monteith PET were obtained from the Brazilian Wind Potential Atlas (Amarante et al., 2001).

Climatological water balances, for a soil water holding capacity (SWHC) of $100 \mathrm{~mm}$, were estimated by Thornthwaite and Mather's method (Thornthwaite and Mather, 1955, 1957) using PET estimated by both TH and PM methods and rainfall data for each one of the 219 places, obtaining monthly AET, WD and WS. PET and AET, WD and WS estimated with PET from TH and PM methods were compared by regression analysis. The SWHC of 100 $\mathrm{mm}$ was adopted as an average of the main soils of the country, considering that each centimeter of depth has the capacity of holding $1 \mathrm{~mm}$ of water (Pereira et al., 2002a). A total depth of $1 \mathrm{~m}$ was considered. This procedure was required to make the results comparable in terms of climate characterization.

WD and WS database obtained by the CWB calculated with PET estimated by TH and PM methods were used to generate the maps of these variables for Brazil, and the differences between them were also spatialized. A geographical information system (ARCVIEW 3.2), was used for that, with interpolation being done by Spline method.

\section{RESULTS AND DISCUSSION}

\section{Comparison between PET estimated by Thornthwaite and FAO Penman-Monteith methods}

Figure 2 presents the relationship between PET estimated by TH and PM methods. In general, this relationship shows a define tendency of PET underestimation by TH method, which is in average around $182 \mathrm{~mm}$ per year. TH method underestimated PM PET by $13 \%$ in $84 \%$ of the places.

Observing Figures 3 and 4, it is possible to identify that for hotter and more humid climates, as observed in Amazon region of Brazil, TH method normally resulted in PM PET overestimation, as also observed by Camargo et al. (1999).

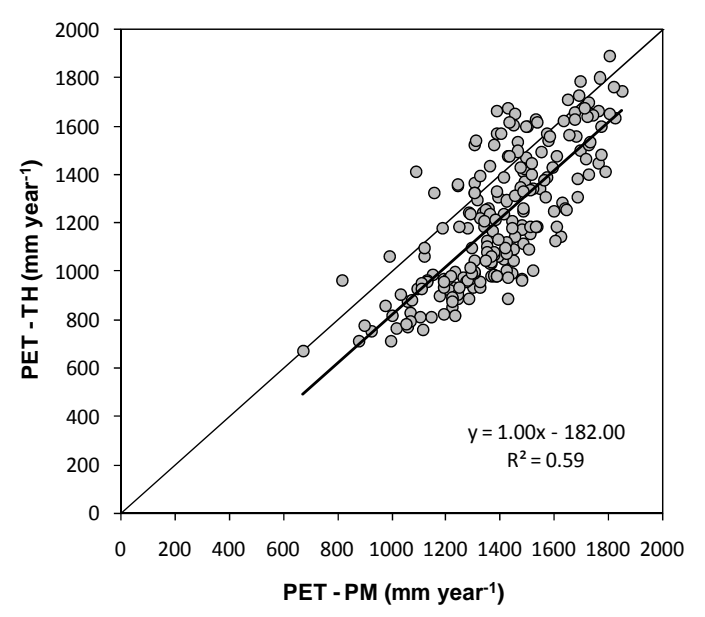

Figure 2. Relationship between annual potential evapotranspiration (PET) estimated by Thornthwaite (TH) and Penman-Monteith (PM) methods for 219 locations in Brazil. 


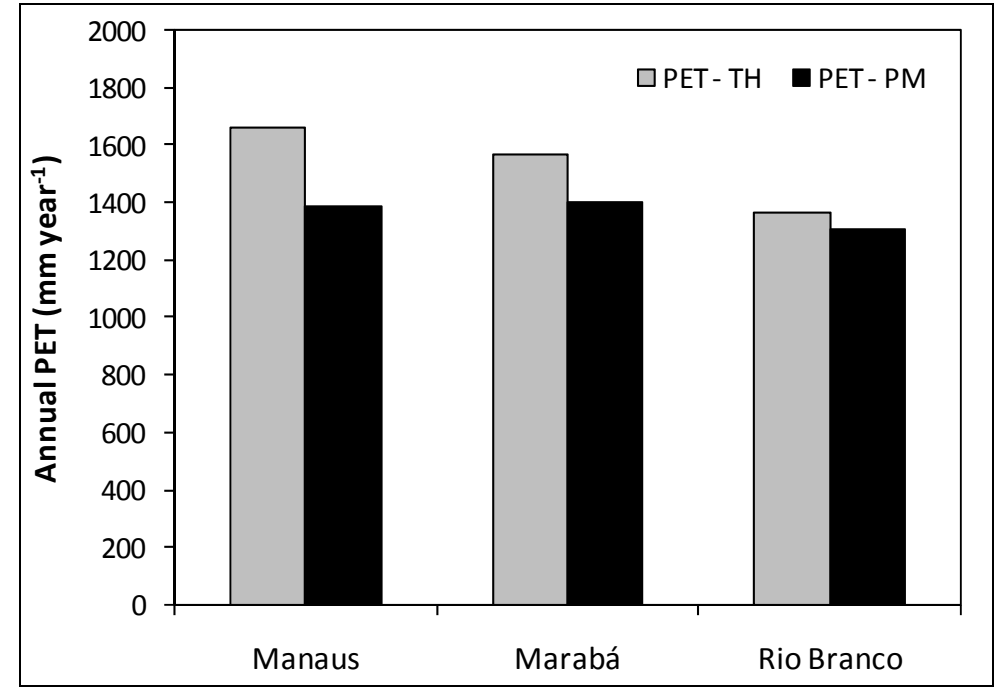

Figure 3. Comparison between annual potential evapotranspiration (PET) data estimated by Thornthwaite (TH) and Penman-Monteith (PM) methods for Manaus (AM), Marabá (PA) and Rio Branco (AC), in the Amazon region, Brazil.

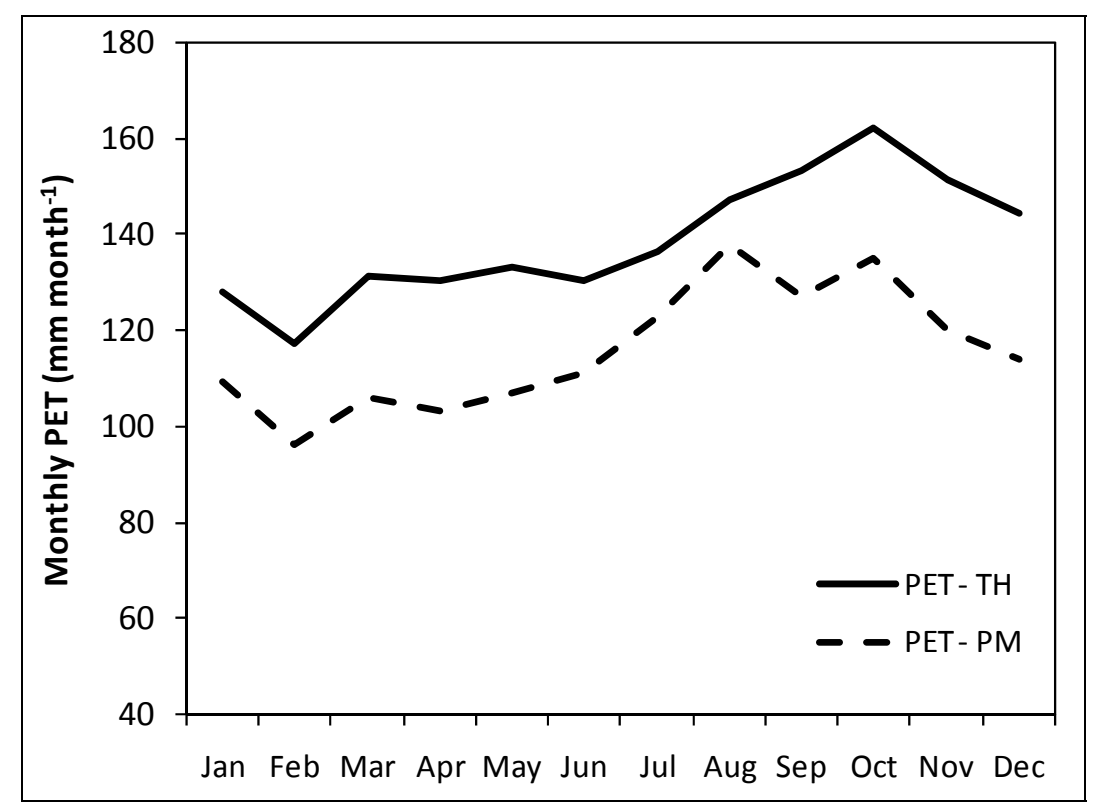

Figure 4. Monthly potential evapotranspiration (PET) estimated by Thornthwaite (TH) and Penman-Monteith (PM) methods for Manaus, Amazonas state, Brazil.

According to Camargo et al. (1999), such performance of TH method in super-humid climates is related to the lack of an aerodynamic term in this method, which just considers the energy term, represented by air temperature. Under this climatic condition, the average relative humidity is normally high, leading to a smaller vapor deficit pressure (VDP) than empirically considered by Thornthwaite in his method. Smaller VDP values will result in smaller PET, for the same condition of temperature.

The lack of an aerodynamic term is also the reason for PET underestimation by TH method in the other regions of the country (Hashemi and Habibian, 1979; Camargo et al., 
1999) when compared with the reference PET method. Under both, drier and cooler climates, the underestimation is substantial, as can be seen in Figures 5 and 6.

Under drier climates, like in Irecê, Goiânia, Dourados, Juiz de Fora and Piracicaba, where the dry season of the year lasts, in average, from April to October, relative humidity is greater and VPD smaller than considered by TH method, which results in smaller PET values, when compared with PM PET. On the other hand, for locations in the southern Brazil, with cooler climates, like in Passo Fundo, the temperature normally does not represent the energy balance appropriately. The presence of frequent polar air masses in this region, after the passage of cold fronts, causes an intense air temperature decrease whereas solar radiation increases as a consequence of clear sky conditions. Such conditions lead to PET underestimation when it is calculated by $\mathrm{TH}$ method, which just considers air temperature as input.

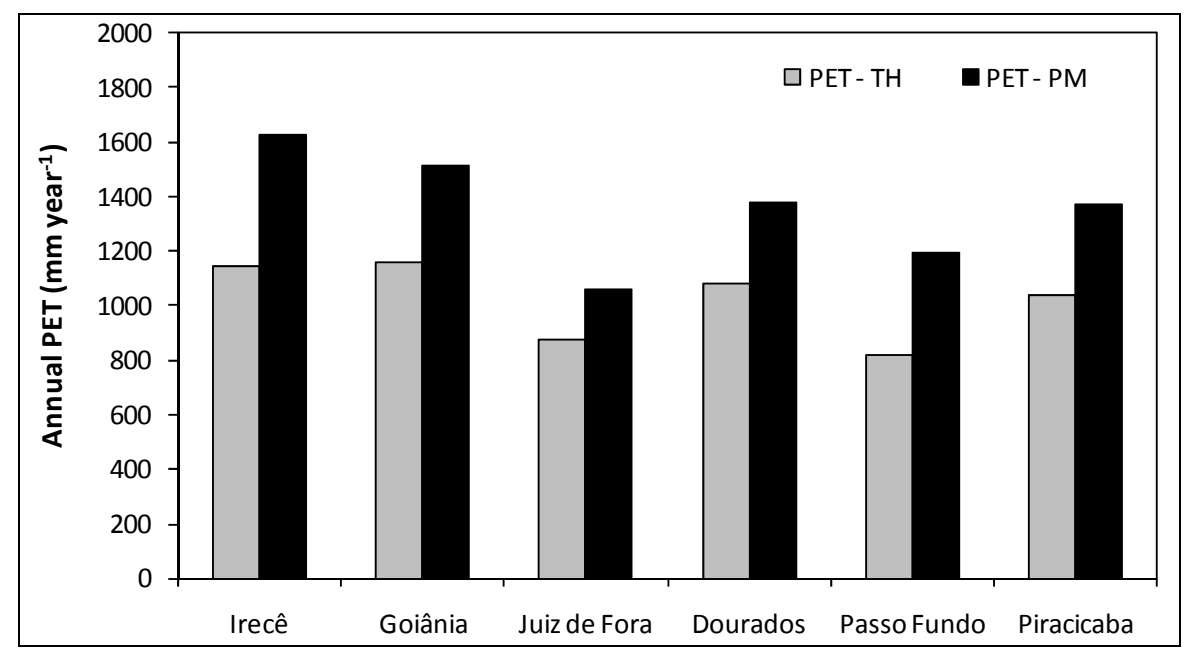

Figure 5. Comparison between annual potential evapotranspiration (PET) data estimated by Thornthwaite (TH) and Penman-Monteith (PM) methods for Irecê (BA), Goiânia (GO), Juiz de For a (MG), Dourados (MS), Passo Fundo (RS) and Piracicaba (SP), Brazil.

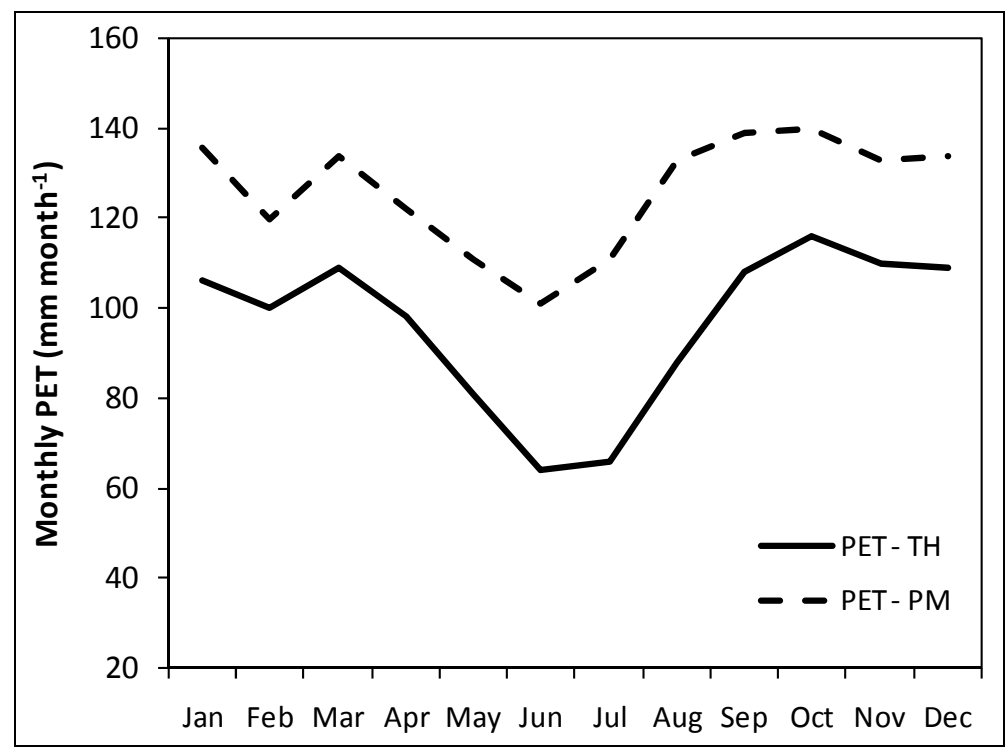

Figure 6. Monthly potential evapotranspiration (PET) estimated by Thornthwaite (TH) and Penman-Monteith (PM) methods for Goiânia, GO, Brazil. 


\section{Effect of PET estimation method on CWB variables}

Considering that there are significant differences between PET estimated by TH and PM methods for the majority of the locations evaluated, it is expected that these differences would be transferred to the other variables of the CWB.

For AET, Figures 7 shows that there is a tendency of underestimation of this variable when CWB is based on PET estimated by TH. This tendency is explained by the fact that AET depends on PET. Once TH method underestimates PET in relation to PM method, it is expected that AET also be underestimated. However, the magnitude of this underestimation is smaller than observed for PET ( $7 \%$ in $69 \%$ of places). For smaller values, normally represented by very dry climates, there is almost no difference between AET estimated with CWB which used TH or PM methods. This fact occurs because under this climatic conditions rainfall is always smaller than PET and, consequently, AET is equal to rainfall, since it is the only source of water for evapotranspiration in these regions.

As a consequence of PET underestimation by TH method and the smaller effect of PET method of calculation on AET, WD is also smaller when estimated by the CWB with TH PET. Figure 8 illustrate this fact, showing that when calculated with TH PET, WD was underestimated by $40 \%(\sim 133 \mathrm{~mm})$ in $83 \%$ of places.

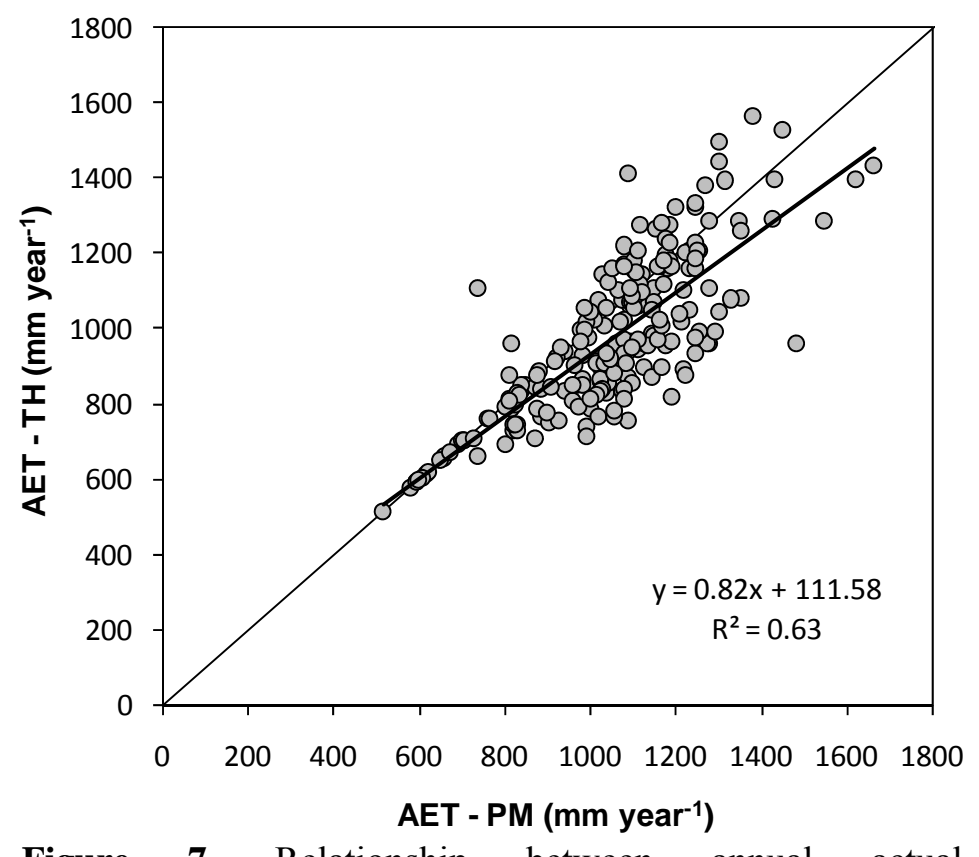

Figure 7. Relationship between annual actual evapotranspiration (AET) when estimated by the climatological water balance with Thornthwaite $(\mathrm{TH})$ and Penman-Monteith (PM) PET, for 219 locations in Brazil.

On the other hand, when TH PET was used to estimate the CWB, WS was overestimated by $80 \%(\sim 147 \mathrm{~mm})$ in $78 \%$ of the places in relation to values obtained with PM PET (Figure 9). For this variable, the overestimation is a result of the smaller values of PET when TH method was used. With smaller PET, the balance between rainfall and PET (R-PET) is of higher magnitude, resulting in greater values of WS during the rainy season. 


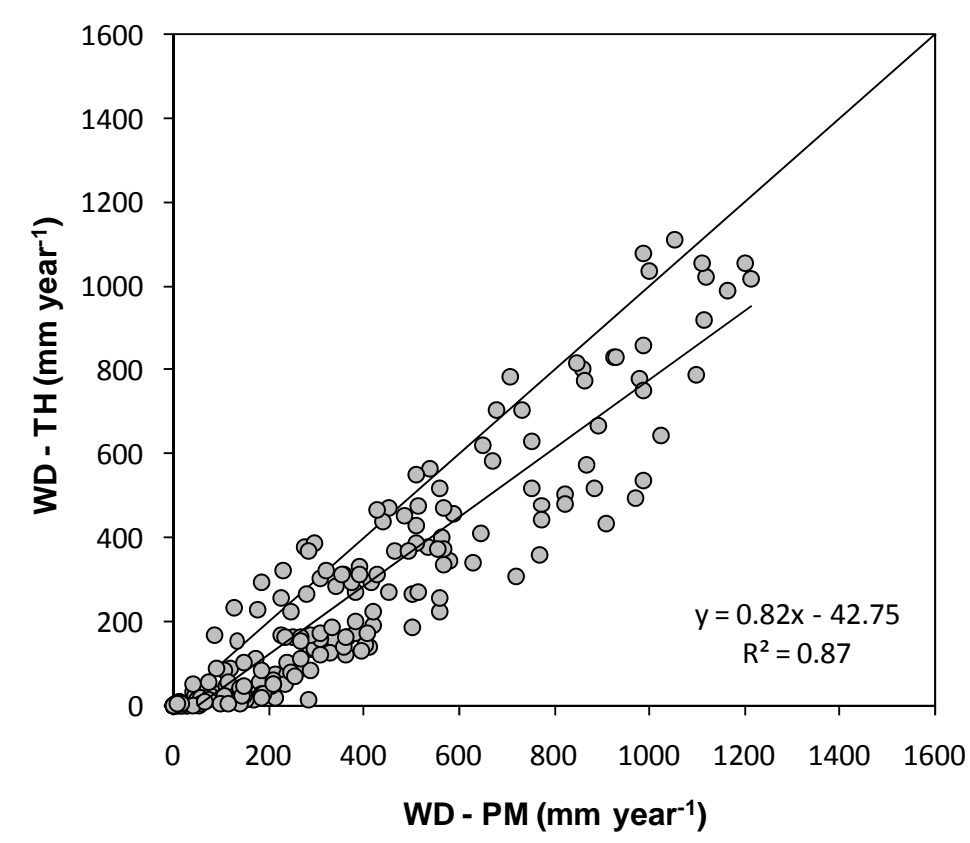

Figure 8. Relationship between annual water deficit (WD) when estimated by the climatological water balance with Thornthwaite (TH) and Penman-Monteith (PM) PET, for 219 locations in Brazil.

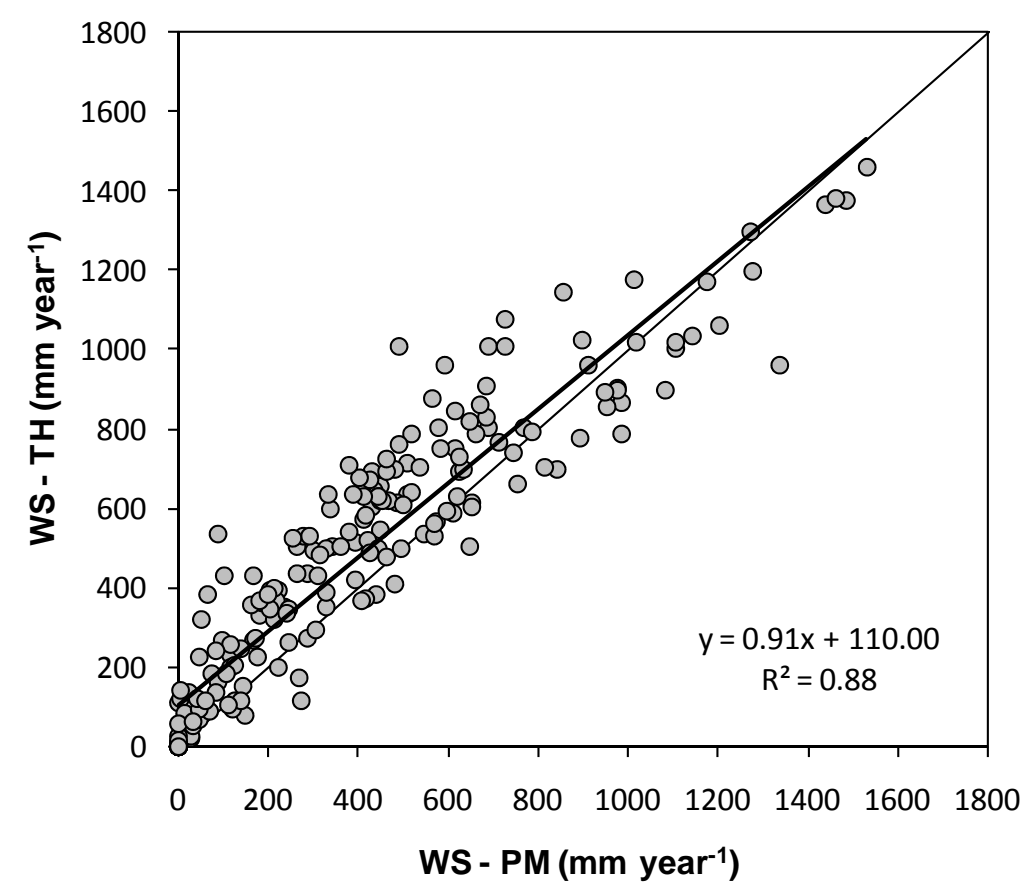

Figure 9. Relationship between annual water surplus (WS) when estimated by the climatological water balance with Thornthwaite (TH) and Penman-Monteith (PM) PET, for 219 locations in Brazil.

\section{Water deficit and water surplus maps for Brazil}

The following figures present the maps for water deficit (Figures 10 and 11) and water surplus (Figures 13 and 14) for Brazil, when the water balance was calculated with TH and 
PM potential evapotranspiration, as well as the deviations between the two WD maps (Figure 12) and WS maps (Figure 15).

The maps show that the use TH PET resulted in an underestimation of the WD in great part of the country, mainly in the extreme north, including Amapá, Amazonas and Roraima states, in the Northeast Region, central Brazil, and west and east of Rio Grande do Sul state (Figures 10,11 and 12). Such underestimation is of great concern in the Northeast Region, north of Minas Gerais state, and in the states of Goiás e Tocantins, where irrigation projects have been based on WD data and maps, calculated with Thornthwaite PET (Itaborahy et al., 2004; Paiva et al., 2007). Only in few areas of Amazonas, Pará, Maranhão and Piauí states, WD was overestimated when Thornthwaite PET was used to determine the water balance. In the other regions of the country, the differences were of smaller magnitude.

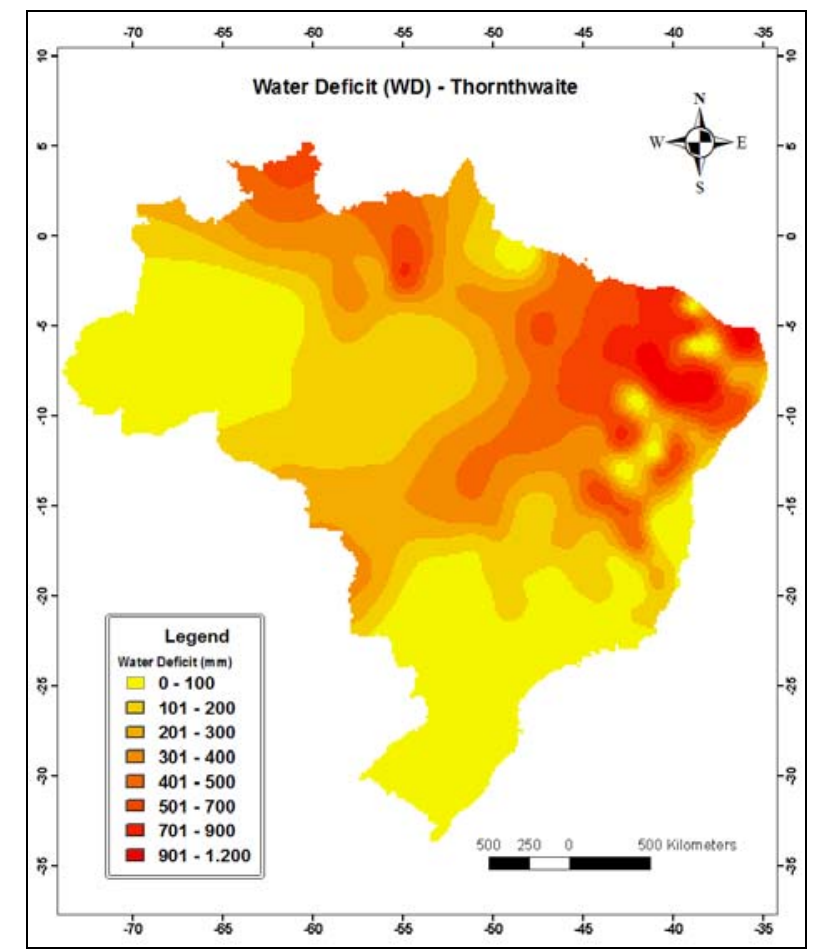

Figure 10. Water deficit map for Brazil, based on Thornthwaite and Mather water balance, for soil water holding capacity of $100 \mathrm{~mm}$, with potential evapotranspiration estimated by Thornthwaite method.

In relation to the WS, the main differences were observed in the center-south of the country, where WS determined with TH PET was overestimated in relation to the WS obtained by the water balance with PM PET (Figures 13, 14 and 15). Such overestimations were also observed in the extreme north of the country, in Roraima and part of Amazonas state. On the other hand, in great part of Amazonas and Acre states and in some areas of Pará and Rio Grande do Sul states, underestimations were observed. 
SENTELHAS, P. C.; SANTOS, D. L.; MACHADO, R. E. Water deficit and water surplus maps for Brazil, based on FAO Penman-Monteith potential evapotranspiration. Ambi-Agua, Taubaté, v. 3, n. 3, p. 28-42, 2008. (doi:10.4136/ambi-agua.59)

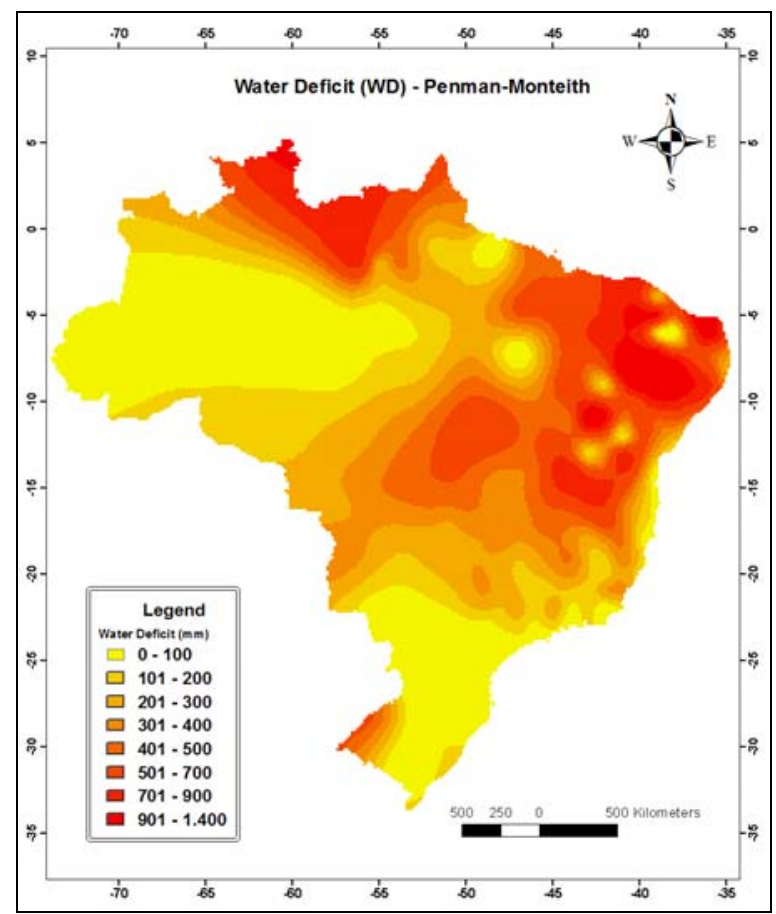

Figure 11. Water deficit map for Brazil, based on Thornthwaite and Mather water balance, for soil water holding capacity of $100 \mathrm{~mm}$, with potential evapotranspiration estimated by Penman-Monteith method.

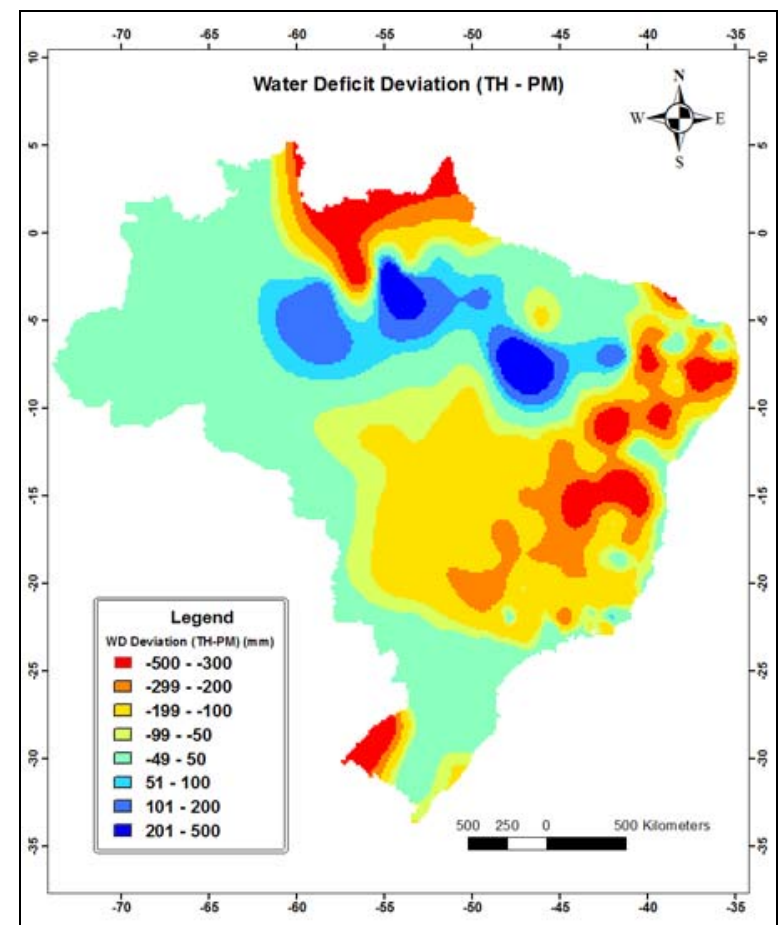

Figure 12. Water deficit deviation map for Brazil, based on Thornthwaite and Mather water balance, for soil water holding capacity of 100 $\mathrm{mm}$, when potential evapotranspiration data were estimated by Thornthwaite and PenmanMonteith methods. 
SENTELHAS, P. C.; SANTOS, D. L.; MACHADO, R. E. Water deficit and water surplus maps for Brazil, based on FAO Penman-Monteith potential evapotranspiration. Ambi-Agua, Taubaté, v. 3, n. 3, p. 28-42, 2008. (doi:10.4136/ambi-agua.59)

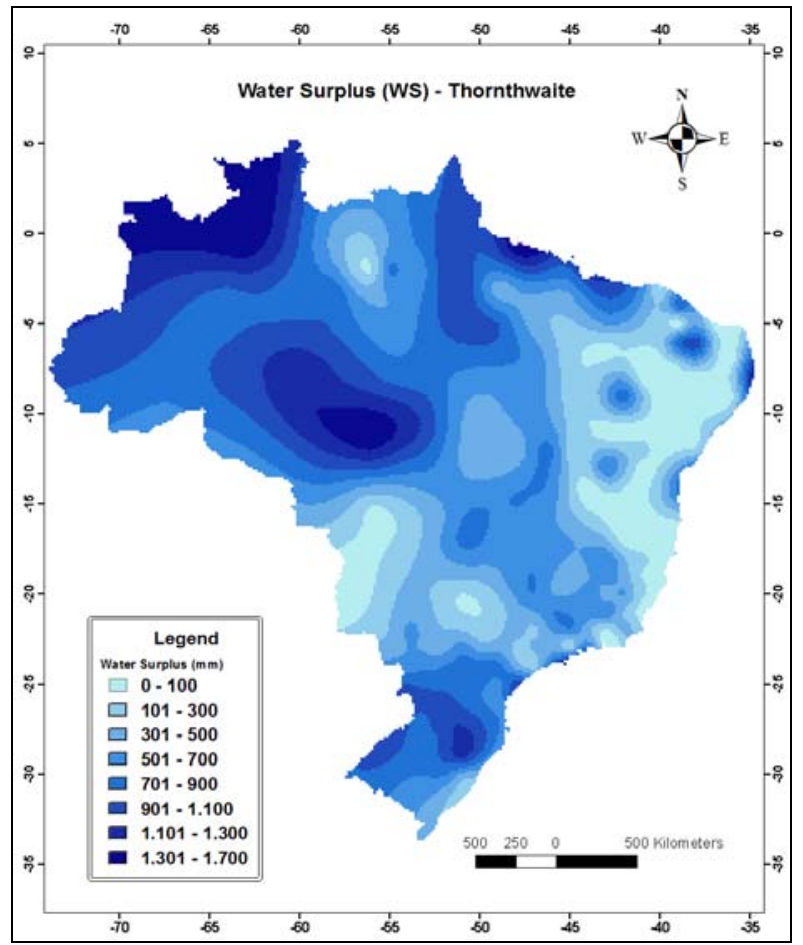

Figure 13. Water surplus map for Brazil, based on Thornthwaite and Mather water balance, for soil water holding capacity of $100 \mathrm{~mm}$, with potential evapotranspiration estimated by Thornthwaite method.

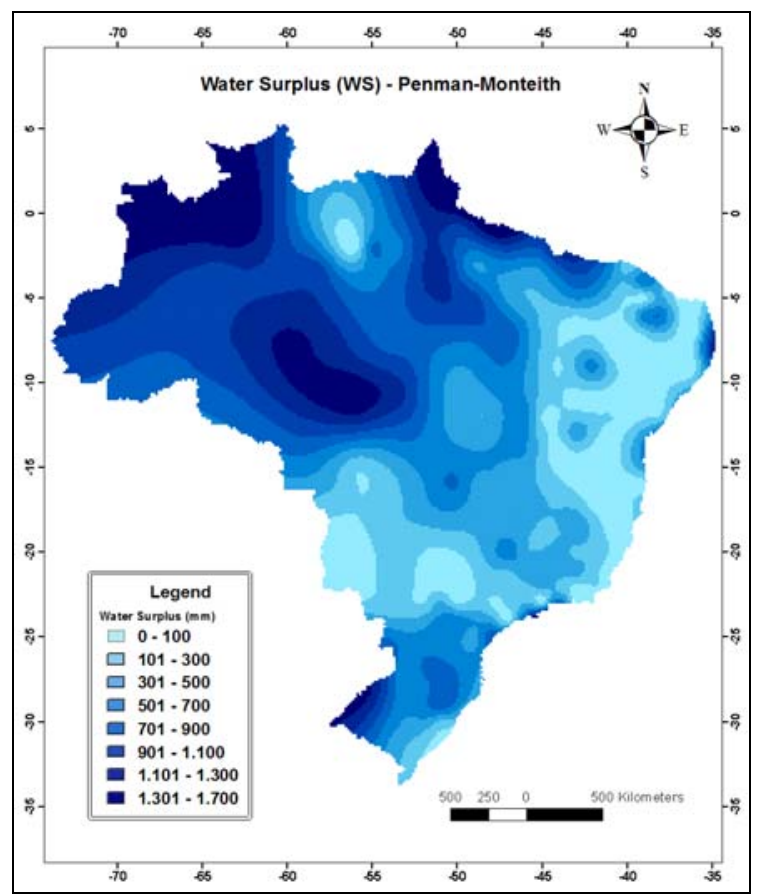

Figure 14. Water surplus map for Brazil, based on Thornthwaite and Mather water balance, for soil water holding capacity of $100 \mathrm{~mm}$, with potential evapotranspiration estimated by Penman-Monteith method. 


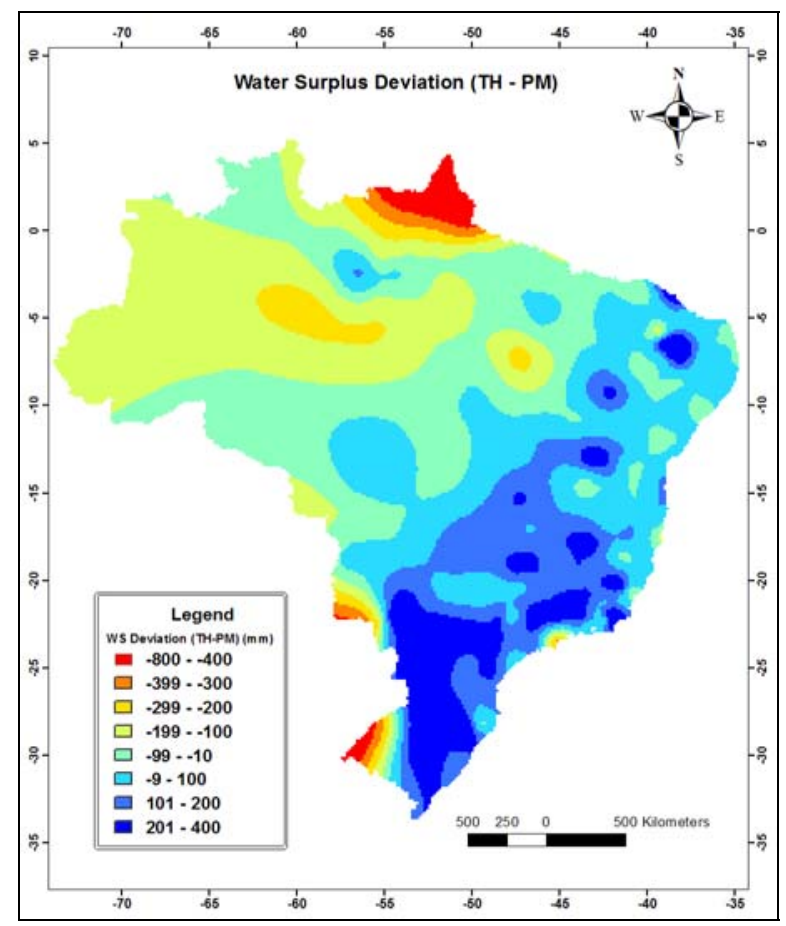

Figure 15. Water surplus deviation map for Brazil, based on Thornthwaite and Mather water balance, for soil water holding capacity of 100 $\mathrm{mm}$, when potential evapotranspiration data were estimated by Thornthwaite and Penman-Monteith methods.

Based on the observations mentioned above, it is clear that the maps of WD and WS obtained from the water balance with PM PET give a more realistic distribution of these variables across the country, since this method is most precise and accurate to estimate PET (Allen et al., 1998). These maps allow users to have better knowledge about these two important variables for hydrological and agricultural processes. The maps of WD and WS determined with TH PET present distortions that can lead to imprecise results when used in projects for agricultural or hydrological planning, as for example under or over dimensioning of irrigation systems or for concession of water use. Therefore, the new maps of WD and WS presented in this study can help government, companies, technical staff, farmers, and users in general to have a better notion of the normal conditions of these variables in all the country, giving support for more precise projects, mainly of agricultural planning, such as agroclimatic zoning, agroclimatic risk management, crop water requirements, dimensioning of irrigation and drainage systems, among others.

\section{CONCLUSIONS}

TH method underestimated annual PM PET by $13 \%$ in $84 \%$ of the places. Such underestimation also led to AET and WD underestimations of $7 \%$ (in $69 \%$ of places) and $40 \%$ (in $83 \%$ of places), respectively. For WS, the use of TH PET data in the CWB resulted in overestimation of about $80 \%$ in $78 \%$ of places. The differences observed in the CWB variables resulted in changes in the maps of WD and WS for Brazil. These new maps, based on PM PET, provide more accurate information, mainly for agricultural and hydrological planning and irrigation and drainage projects. 


\section{REFERENCES}

ALLEN, R. G. A Penman for all seasons. Journal of Irrigation and Drainage Eng., v. 112, n. 4, p. 348-368, 1986.

ALLEN, R. G.; JENSEN, M. E.; WRIGHT, J.; BURMAN, R. D. Operational estimates of reference evapotranspiration. Agronomy Journal, v. 81, p. 650-662, 1989.

ALlEN, R. G.; PEREIRA, L. S.; RAES, D.; SMITH, M. Crop evapotranspiration: guidelines for computing crop water requirements. Rome: FAO, 1998. (Irrigation and Drainage, 56).

AMARAnTE, O. A. C.; BROWER, M.; ZACK, J.; SÁ, A. L. Atlas do potencial eólico brasileiro. Brasília: Ministério de Minas e Energia - ELETROBRAS, 2001.

BACK, A. J. Variação da evapotranspiração de referência calculada em diferentes intervalos de tempo. Engenharia Agrícola, v. 27, n. 1, p. 139-145, 2007.

BLACK, P. Revising the Thornthwaite and Mather water balance. Journal of the American Water Resources Association, v. 43, n. 6, p. 1604-1605, 2007.

CAMARGO, A. P. Contribuição para a determinação da evapotranspiração potencial no Estado de São Paulo. Bragantia, Campinas, v. 21, p. 163-203, 1962.

CAMARGO, A. P. Balanço hídrico no Estado de São Paulo. 4.ed. Campinas: Instituto Agronômico, 1978. 28p. (Boletim, 116).

CAMARGO, A. P.; SENTELHAS, P. C. Avaliação do desempenho de diferentes métodos de estimativa da evapotranspiração potencial no Estado de São Paulo. Revista Brasileira de Agrometeorologia, Santa Maria, v. 5, n. 1, p. 89-97, 1997.

CAMARGO, A. P.; MARIN, F. R.; SENTELHAS, P. C.; PICINI, A. G. Ajuste da equação de Thornthwaite para estimar a evapotranspiração potencial em climas áridos e superúmidos, com base na amplitude térmica. Revista Brasileira de Agrometeorologia, Santa Maria, v. 7, n. 2, p. 251-257, 1999.

CAMARGO, A. P.; CAMARGO, M. B. P. Uma revisão analítica da evapotranspiração potencial. Bragantia, Campinas, v. 59, n. 2, p. 125-137, 2000.

HASHEMI, F.; HABIBIAN, M. T. Limitations of temperature-based methods in estimating crop evapotranspiration in arid-zone agricultural development projects. Agricultural Meteorology, v. 20, p. 237-247, 1979.

ITABORAhy, C. R.; SAnTOS, D. G.; REZENDE, L. S.; PRETO, L. A. Agricultura Irrigada: projeto de gerenciamento integrado das atividades desenvolvidas em terra na bacia do são Francisco. Brasília: ANA/GEF/PNUMA/OEA, 2004. 102p. (Estudo Técnico de Apoio ao PBHSF, 12).

MEDEIROS, A. T.; SENTELHAS, P. C.; LIMA, R. N. Estimativa da evapotranspiração de referência a partir da equação de Penman-Monteith, de medidas lisimétricas e de equações empíricas, em Paraipaba, CE. Engenharia Agrícola, Jaboticabal, v. 23, n. 1, p. 31-40, 2003. 
PAIVA, Y. G.; SILVA, K. R.; CECÍlIO, R. A.; PEZZOPANE, J. E. M.; PEREIRA, M. C. Uso de dados GTOPO30 e redes neurais para a espacialização de elementos climáticos. Parte II - Evapotranspiração potencial para o estado da Bahia. IN: SIMPÓSIO BRASILEIRO DE SENSOREAMENTO REMOTO, 13., 2007, Florianópolis. Anais... São José dos Campos: INPE, 2007. p. 4129-4134.

PEREIRA, A. R.; ANGELOCCI, L. R.; SENTELHAS, P. C. Agrometeorologia: fundamentos e aplicações práticas. Guaíba: Agropecuária, 2002a. 478p.

PEREIRA, A. R.; SENTElHAS, P. C.; FOlEGATTI, M. V.; NOVA, N. A. V.; MAGGIOTTO, S. R.; PEREIRA, F. A. C. Substantiation of the daily FAO-56 reference evapotranspiration with data from automatic and conventional weather stations. Revista Brasileira de Agrometeorologia, Santa Maria, v. 10, n. 2, p. 251-257, 2002 b.

PEREIRA, F. A. C. Desempenho do modelo de Penman-Monteith de dois evapotranspirômetros na estimativa da evapotranspiração de referência (ETo) em relação a um lisímetro de pesagem. 1998. 87f. Tese (Doutorado em Irrigação e Drenagem) - Escola Superior de Agricultura "Luiz de Queiroz", Universidade de São Paulo, Piracicaba, 1998.

SENTELHAS, P. C. Estimativa diária da evapotranspiração de referência com dados de estações meteorológicas convencional e automática. 1998. 97f. Tese (Doutorado em Irrigação e Drenagem) - Escola Superior de Agricultura "Luiz de Queiroz", Universidade de São Paulo, Piracicaba, 1998.

THORNTHWAITE, C. W. An approach toward a rational classification of climate. Geographical Review, New York, v. 38, n. 1, p. 55-94, 1948.

THORNTHWAITE, C. W.; MATHER, J. R. The water balance. Centerton: Drexel Institute of Technology - Laboratory of Climatology, 1955. 104p. (Publications in Climatology, v. 8, n. 1)

THORNTHWAITE, C. W.; MATHER, J. R. Instructions and tables for computing potential evapotranspiration and water balance. Centerton: Drexel Institute of Technology Laboratory of Climatology, 1957.311p. 


ISSN = 1980-993X - doi:10.4136/1980-993X
www.agro.unitau.br/ambi-agua
E-mail: ambi-agua@agro.unitau.br
Tel.: (12) 3625-4116

\title{
Rainfall-runoff process analysis of the Pequeno River catchment, Curitiba metropolitan region, Brazil, with two hydrological models
} (doi:10.4136/ambi-agua.60)

\author{
Pedro Luiz Borges Chaffe ${ }^{1}$; Roberto Valmir da Silva ${ }^{1}$; Masato Kobiyama ${ }^{2}$ \\ ${ }^{1}$ Graduate course of Environmental Engineering, Federal University of Santa Catarina \\ ${ }^{2}$ Department of Sanitary and Environmental Engineering, Federal University of Santa Catarina, Caixa Postal \\ 476, Florianópolis-SC, CEP88040-900, Brasil. www.labhidro.ufsc.br \\ E-mail: \{chaffe, roberto, kobiyama\}@ens.ufsc.br
}

\begin{abstract}
The rainfall-runoff process of the Pequeno River catchment, located in the Curitiba metropolitan region, Paraná State, Brazil was analyzed with two hydrological models, TOPMODEL and HYCYMODEL. Both models were applied to a series of 3360 hourlyobserved rainfall-runoff data. The simulations of those models were compared in terms of total runoff generation and hydrograph separation. The uncertainty intervals were estimated for each model using the GLUE method. Both models presented a satisfactory and similar efficiency for the total runoff simulation. The ratio between total runoff and total precipitation was $0.79,0.81$ and 0.74 for the observed data, those calculated with TOPMODEL and with HYCYMODEL, respectively. The models also estimated a large quantity of the baseflow contributing to the total runoff $(77.7 \%$ with TOPMODEL and $84.5 \%$ with HYCYMODEL), but there was a significant difference of those quantities between the models. The surface flow analysis showed that TOPMODEL considered that the catchment saturates and drains faster than HYCYMODEL.
\end{abstract}

Keywords: Pequeno River catchment; rainfall-runoff process; TOPMODEL; HYCYMODEL.

\section{Análise do processo chuva-vazão da bacia do rio Pequeno, região metropolitana de Curitiba, Brasil, usando dois modelos hidrológicos}

\section{RESUMO}

O processo de chuva-vazão da bacia do rio Pequeno, localizada na região metropolitana de Curitiba, estado do Paraná, Brasil, foi analisado por meio de dois modelos hidrológicos, TOPMODEL e HYCYMODEL. Uma série de 3360 dados horários de chuva-vazão foi utilizada em ambos os modelos. As simulações foram comparadas em termos de vazão total e de separação de escoamento. Os intervalos de incerteza das simulações de cada modelo foram estimados pelo método GLUE. Ambos os modelos apresentaram eficiências satisfatórias e similares na simulação de escoamento total. A razão entre escoamento total e precipitação foi de $0,79,0,81$ e 0,74 para os dados observados, calculados com o TOPMODEL e com o HYCYMODEL, respectivamente. Os modelos estimaram uma grande quantidade de escoamento de base contribuindo para o escoamento total $(77,7 \%$ para o TOPMODEL e $84,5 \%$ para o HYCYMODEL), porém, houve uma diferença significativa dessas quantidades entre os modelos. A análise do escoamento superficial mostrou que o TOPMODEL considerou que a bacia satura e drena mais rapidamente do que nas simulações com o HYCYMODEL.

Palavras-chave: Bacia do rio Pequeno; processo chuva-vazão; TOPMODEL; HYCYMODEL. 


\section{INTRODUCTION}

The Pequeno River catchment, located in the Curitiba metropolitan region, Paraná State, Brazil, has undergone a fast and accelerated urbanization due to the economic development of this region. Hence, studies about hydrological processes in this catchment are very important to environmental planning (Santos, 2001; Santos and Kobiyama, 2008). For future problems solutions of urban drainage and drinking-water supply, the estimation of surface flow and baseflow, i.e., hydrograph separation, is an important item of this catchment hydrology. There are many different ways to analyze the hydrograph of a catchment. One of them is using hydrological models to simulate rainfall-runoff processes.

A well known rainfall-runoff models is TOPMODEL (Topography-based hydrological Model) (Beven and Kirkby, 1979). Because of its free availability in the Internet and its simple formulation, TOPMODEL has been widely used since it was first coded. This model is based on the concept of 'storage deficit', which is a function of a hydrological similarity index. This index is called 'topographic index' and is calculated from the catchment topography. TOPMODEL is considered a semi-distributed and physically based model, since runoff routing depends on the distribution of the topographic index in the catchment. It was previously applied to the Pequeno River catchment, but focusing on the saturated areas (Santos and Kobiyama, 2008) and on the comparison of different versions of the model (Silva and Kobiyama, 2007).

On the other hand, the HYCYMODEL (Hydrological Cycle Model) developed by Fukushima and Suzuki (1986) and Fukushima (1988) was based on hydrological processes observations in a small forested mountain catchment in Japan and is considered a conceptual and lumped model. This model estimates phenomenon such as evaporation, transpiration and hydrograph separation. HYCYMODEL was applied to some Brazilian catchments and showed satisfactory results (Kobiyama and Chaffe, 2008; Kobiyama et al., 2009).

The main objective of the present study was to analyze the rainfall-runoff processes of the Pequeno River catchment by applying and comparing results of these two different hydrological models, TOPMODEL and HYCYMODEL.

\section{MATERIAL AND METHODS}

\subsection{Study Area}

The Pequeno River catchment $\left(104 \mathrm{~km}^{2}\right)$ is located in São José dos Pinhais city, Curitiba metropolitan region, Paraná State, Brazil (Figure 1). The topography is characterized by moderate slopes and its elevation varies from $895 \mathrm{~m}$ to $1270 \mathrm{~m}$. The land use of this catchment comprises urban area (4\%), agriculture and exposed areas $(3 \%)$, forest $(54 \%)$, grassland (35\%), wetland (3\%) and others (1\%). At least $15 \%$ of the catchment is permanently saturated (Santos and Kobiyama, 2008). The mean annual precipitation is approximately 1400mm (Santos, 2001).

\subsection{Hydrological Data}

The hydrological data used in this study are from the Fazendinha gauge station and the Chácara Guajubi meteorological station (Figure 1). The evapotranspiration data used in TOPMODEL were calculated with the modified Penman method (Doorenbos and Pruit, 1977). The series of the observed rainfall and runoff data and the estimated evapotranspiration data are from August 14th, 2000, to January 1st, 2001, with 3360 hourly measured data (Figure 2). 

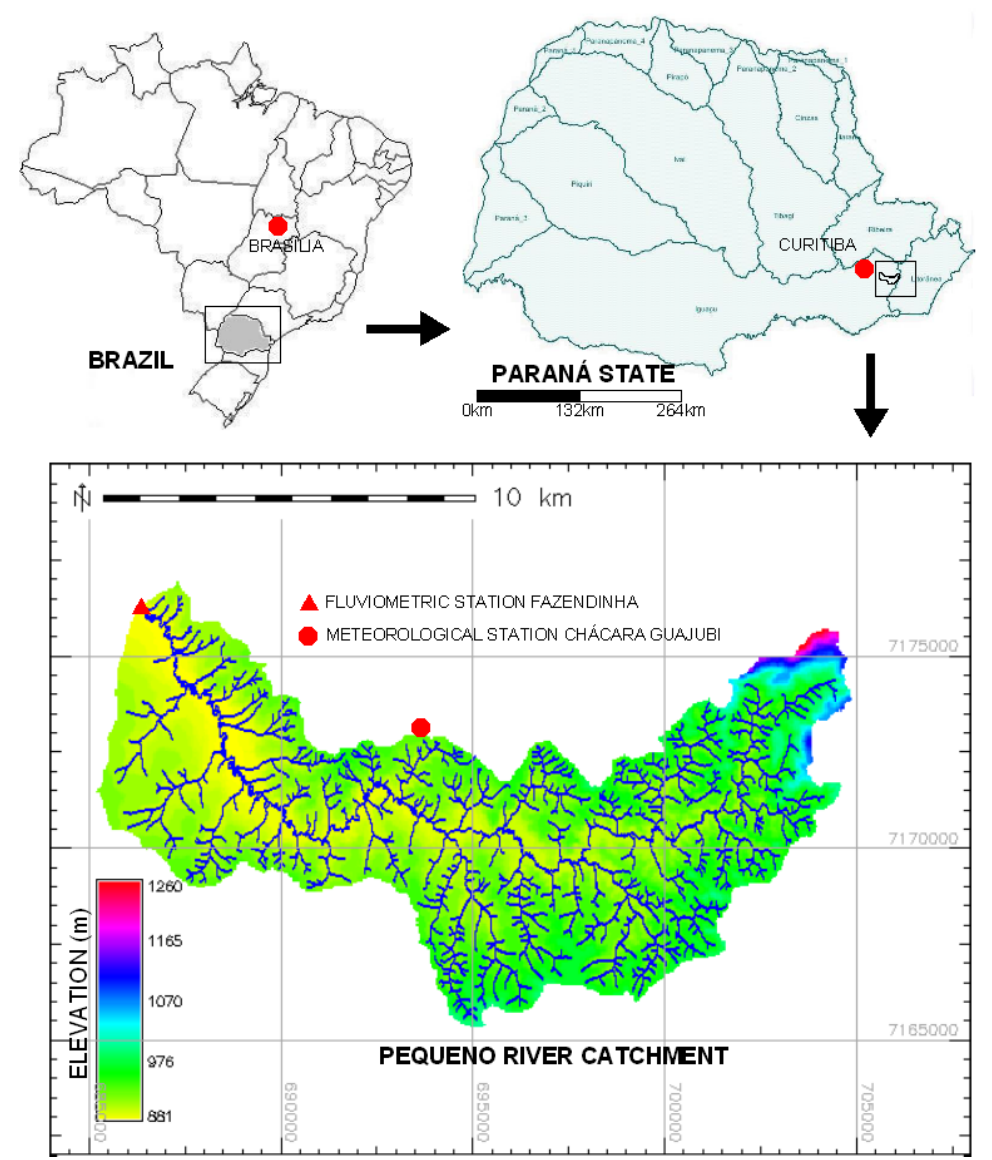

Figure 1. Pequeno River Catchment.

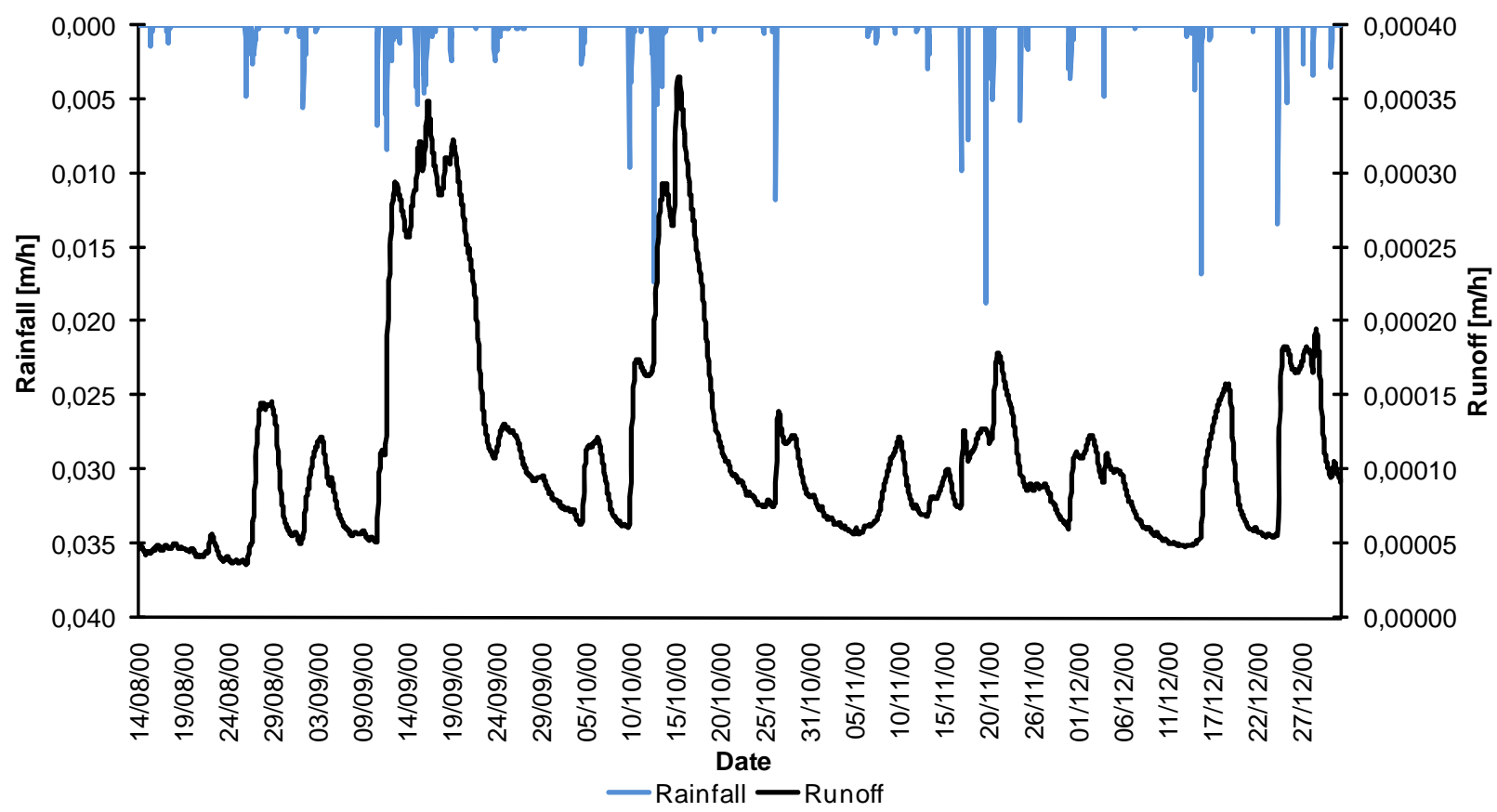

Figure 2. Rainfall-runoff data. 


\subsection{TOPMODEL}

The TOPMODEL is a rainfall-runoff model that uses the concept of hydrological similarity based on topography (Beven et al., 1995). This similarity is defined by the topographic index $\lambda_{i}$ :

$$
\lambda_{i}=\ln \left(\frac{a_{i}}{\tan \beta_{i}}\right)
$$

where $a_{\mathrm{i}}$ is the upslope contributing area per unit contour length for each cell $\mathrm{i}$ in the catchment; and $\tan \beta_{\mathrm{i}}$ is the slope of this cell measured with respect to plan distance.

The storage deficit $S_{i}$ for each cell with the same hydrological similarity is:

$$
S_{i}=S+m\left(\lambda-\lambda_{i}\right)
$$

where $S$ is the lumped or mean storage deficit for the entire catchment; $\lambda$ is the mean topographic index (approximated by a weighed average over the areas with the same hydrological similarity); $\lambda_{i}$ is the local topographic index and $m$ is a parameter associated with the rate of decline of the catchment recession curve.

For each time step the storage deficit is updated following the equation:

$$
S_{t}=S_{t-1}+\left(\frac{Q b_{t-1}-Q v_{t-1}}{A}\right)
$$

where $S_{t}$ is the updated value of the storage deficit; $S_{t-1}$ is the storage deficit in the previous time step; $Q b_{t-1}$ is the base flow in the previous time step; $Q v_{t-1}$ is the unsaturated zone recharge in the previous time step; and $A$ is the catchment area. This recharge is defined by:

$$
q_{v i}=\frac{S_{U Z}}{S_{i} T_{D}}
$$

where $S_{U Z}$ is the unsaturated zone deficit; and $T_{D}$ is residence time in the unsaturated zone. The maximum value for $S_{U Z}$ is determined by the parameter $S R_{M A X}$.

The baseflow is defined by:

$$
Q_{b}=Q_{S} e^{\left(\frac{-S}{m}\right)}
$$

where $Q_{s}$ is the discharge when the catchment is saturated and is calculated by:

$$
Q_{S}=A T_{0} e^{-\lambda}
$$

where $T_{0}$ is the soil saturated transmissivity, which is constant for the entire catchment.

In the first time step the mean storage deficit is estimated by: 


$$
S_{t=0}=-m \cdot \ln \left(\frac{Q_{0}}{Q_{S}}\right)
$$

where $\mathrm{Q}_{0}$ is the initial discharge at time $\mathrm{t}=0$.

TOPMODEL uses the Dunne (Dunne and Black, 1970) overflow generation mechanism, i. e., when the storage deficit (Equation 2) equals to zero. Flow routing is done through a time-area histogram. This histogram is derived from a distance-area function using the following equation:

$$
t c=\sum_{i=1}^{N} \frac{l_{i}}{R \tan \beta_{i}}
$$

where $t c$ is the time of concentration of a determined area of the catchment; $R V$ is a velocity parameter; and $l_{i}$ is the plan flow path length from a cell $i$ to the basin outlet.

\subsection{HYCYMODEL}

The HYCYMODEL consists of five tanks that express river and hillslope systems. For complete flowchart see Fukushima (1988), Kobiyama and Chaffe (2008). Using the ratio of impermeable area, $C$, rainfall is divided into the channel rainfall $R_{c}(t)$ and the gross rainfall $R_{g}(t)$ where $t$ is the time. Tank I shows the interception process, which is defined as:

$$
R_{n}(t)=A G \cdot R_{g}(t)-A I
$$

where $R_{n}(t)$ is the net rainfall; and $A G$ and $A I$ are the interception parameters. The interception $E_{i}(t)$ is the difference between $R_{n}(t)$ and $R_{g}(t)$.

The effective rainfall $R_{e}(t)$ can be determined with the storage $S_{u}(t-1)$ in Tank II and the net rainfall. $D_{16}$ and $D_{50}$ are defined as the effective top-soil depths, in which the ratios of the contributing area are equivalent to $16 \%$ and $50 \%$, respectively. Then, the standard deviation is:

$$
\sigma=\log \left(\frac{D_{50}}{D_{16}}\right)
$$

The variable $\xi$ is:

$$
\xi=\frac{\log \left(\frac{S_{u}(t-1)+R_{n}(t)}{D_{50}}\right)}{\sigma}
$$

The ratio of the contribution area, $m_{h y}$, is:

$$
m_{h y}=\int_{-\infty}^{\xi} \frac{1}{\sqrt{2 \pi}} \exp \left(-\frac{\xi^{2}}{2}\right) d \xi
$$

Finally,

$$
R_{e}(t)=m_{h y} \cdot R_{n}(t)
$$


Tanks III, IV and V represent the groundwater system, the subsurface water system and the channel system, which determine the base flow $Q_{b}(t)$, the subsurface flow on hillslope $Q_{h}(t)$ and the direct runoff in channel $Q_{c}(t)$, respectively. In Tanks II, III, IV and V, the relation between the storage $S_{h y}$ and the discharge $Q$ is expressed by the storage function, i.e.,

$$
S_{h y}=K Q^{P}
$$

where $K$ and $P$ are the storage function parameters. For Tanks II, III, IV and V, $K$ and $P$ are defined $K_{u}$ and $P_{u}, K_{b}$ and $P_{b}, K_{h}$ and $P_{h}$ and $K_{c}$ and $P_{c}$, respectively. Once Tanks IV and V form the direct runoff, the values of $P_{h}$ and $P_{c}$ are 0.6 derived from the kinematic wave aproach (Fukushima, 1988). And once Tank II, which presents the linear phenomenon, the value of $P_{u}$ is 1.0 . The value of $P_{b}$ is 0.1 and was calculated using the least square error (Fukushima, 1988).

The transpiration ratio is:

$$
E_{t}(t)=\operatorname{Delta}\left\{P_{t a}+P_{t b} \sin \left[30^{\circ}-(I-I G)\right]\right\}
$$

where Delta, $P_{t a}, P_{t b}$ and $I G$ are the parameters and $I$ is the month number (1 to 12). Transpiration in a drought situation decreases when the storage of Tank II is smaller than $S_{b c}$. The critical discharge for transpiration $Q_{b c}$ corresponds to $S_{b c}$. The evapotranspiration $E(t)$ is the sum of $E_{i}(t), E_{t}(t)$ and the channel evaporation $E_{c}(t)$.

For hourly measured data, five more parameters need to be calibrated in the interception subsystem than those in Kobiyama and Chaffe (2008): $a_{1}$ (rate of rain interception by canopy), $a_{2}$ (rate of stem flow), $S_{1}$ (maximum storage in canopy), $S_{2}$ (maximum storage in stems) and EVI (evaporation intensity of the intercepted rain). This is modified structure of Tank I as proposed by (Suzuki et al., 1979).

\subsection{The GLUE method}

In a model calibration, it is very likely that more than one set of parameters produce similar results. This particularity is called "equifinality" (Beven and Binley, 1992). Equifinality, data acquisition and model formulation are some of the many causes of uncertainty in a modeling study. Therefore, to estimate the uncertainty in a given simulation, Beven and Binley (1992) proposed the use of the GLUE (Generalized Likelihood Uncertainty Estimation) Method. In order to use this method, it is required to: (1) choose a feasible sampling range for each parameter; (2) choose a method for generating parameter values; (3) choose an appropriate likelihood measure; and (4) decide the likelihood value for acceptance or rejection of a determined parameter set.

The sampling range might be determined based on field observation, literature recommendations and previous simulations. For this study, it was chosen the Monte Carlo method for parameter sampling, which generates random values based on a uniform probability distribution. The likelihood measure should be determined by the prediction problem nature. In the present study, the Nash coefficient (Nash and Sutcliffe, 1970) was used because of its sensitivity to hydrograph peaks. 


$$
E(\Theta)=1-\frac{\sum_{t=1}^{N}(o(t)-\hat{o}(t \mid \Theta))^{2}}{\sum_{t=1}^{N}(o(t)-\bar{o})^{2}}
$$

where $E(\Theta)$ is the Nash coefficient for the set of parameters $\Theta$; $o(t)$ is the variable observed in the time step $t ; \hat{o}(t \mid \Theta)$ is the variable calculated for the time step t using the set of parameters $\Theta ; o$ is the mean value of the observed variable; and $N$ is the number of time steps.

\subsection{Parameter Estimation}

Five parameters in TOPMODEL and sixteen in HYCYMODEL needed to be calibrated. The sampling range for each parameter in both models was chosen based on previous simulations. The parameters and ranges used for calibrating the TOPMODEL and HYCYMODEL are in Table 1 and 2, respectively. Also based on previous simulations, the Nash coefficient (E) equal to 0.3 was adopted as the likelihood value for acceptance (behavioral) or rejection (non-behavioral) of the parameter set.

Table 1. TOPMODEL parameters and sampling range.

\begin{tabular}{cc}
\hline Parameter & Range \\
\hline$m(\mathrm{~m})$ & $0.003-0.100$ \\
$\ln T_{0}\left(\ln \left(\mathrm{m}^{2} \mathrm{~h}^{-1}\right)\right)$ & $0.001-10.000$ \\
$T_{D}\left(\mathrm{~h} \mathrm{~m}^{-1}\right)$ & $0.05-120.00$ \\
$R V\left(\mathrm{~m} \mathrm{~h}^{-1}\right)$ & $300-2000$ \\
$S R_{M A X}(\mathrm{~m})$ & $0.00001-0.00200$ \\
\hline
\end{tabular}

Table 2. HYCYMODEL parameters and sampling range.

\begin{tabular}{cccc}
\hline Parameter & Range & Parameter & Range \\
\hline$C$ & $0.010-0.100$ & $a_{2}$ & $0.100-0.900$ \\
$D_{16}(\mathrm{~mm})$ & $10.0-30.0$ & $S_{1}(\mathrm{~mm})$ & $1.000-1.800$ \\
$D_{50}(\mathrm{~mm})$ & $50.0-80.0$ & $S_{2}(\mathrm{~mm})$ & $0.100-0.900$ \\
$K_{c}\left(\mathrm{~mm}^{2 / 5} \mathrm{~h}^{3 / 5}\right)$ & $1.0-200.0$ & $E V I(\mathrm{~mm} / \mathrm{h})$ & $0.010-0.800$ \\
$K_{h}\left(\mathrm{~mm}^{2 / 5} \mathrm{~h}^{3 / 5}\right)$ & $1.0-200.0$ & $P_{t a}(\mathrm{~mm})$ & $10.00-50.00$ \\
$K_{u}(\mathrm{~h})$ & $5.0-300.0$ & $P_{t b}(\mathrm{~mm})$ & $10.00-50.00$ \\
$K_{b}\left(\mathrm{~mm}^{9 / 10} \mathrm{~h}^{1 / 10}\right)$ & $50.0-1000.0$ & $I G$ & $9.0-14.0$ \\
$a_{1}$ & $0.100-0.900$ & $Q_{b c}(\mathrm{~mm} /$ day $)$ & $0.6-2.0$ \\
\hline
\end{tabular}

\section{RESULTS AND DISCUSSION}

Both models were applied to the series of 3360 hourly observed data. Among the twenty thousand runs carried out for each model, there were 11045 and 4710 sets of parameters considered behavioral ( $\mathrm{E} \geq 0.3$ ) in TOPMODEL and in HYCYMODEL, respectively. Using the behavioral simulations, the uncertainty bounds of $5 \%$ and $95 \%$ were calculated for each model. Figure 3 shows the observed discharge and the uncertainty bounds for TOPMODEL and HYCYMODEL. 


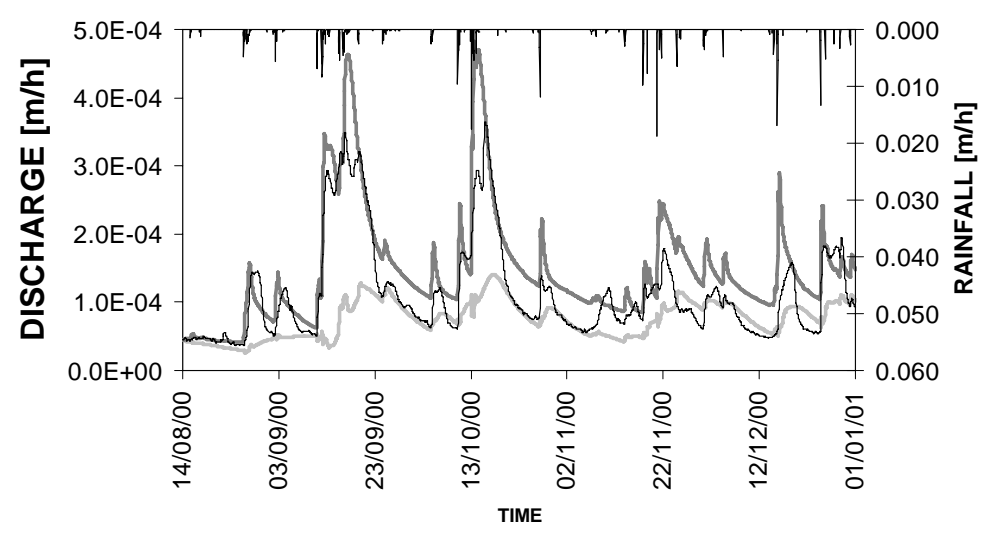

(a) - 5\% Bound - 95\% Bound - Observed Runoff - RAINFALL

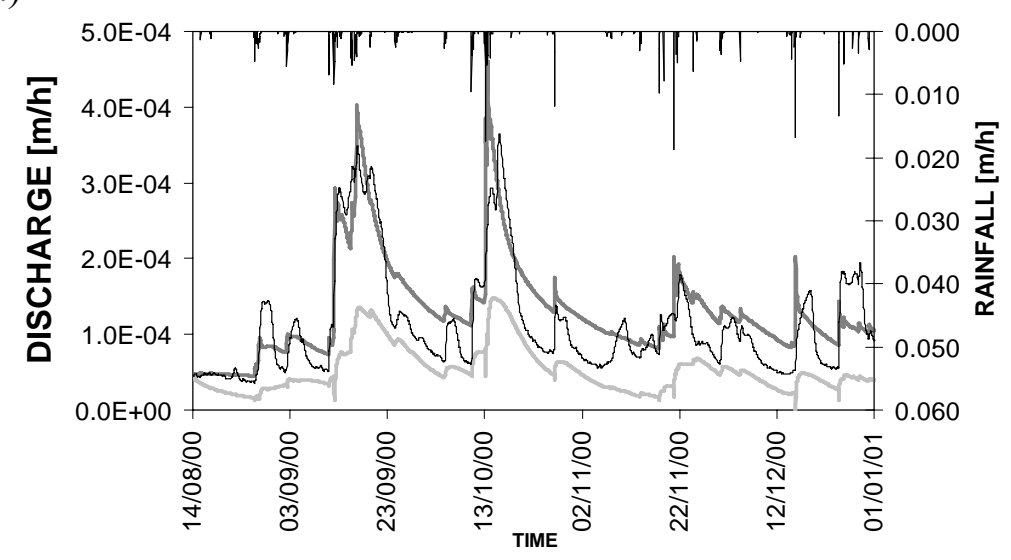

(b) $5 \%$ Bound - 95\% Bound - Observed Runoff - RAINFALL

Figure 3. Uncertainty bounds: (a) TOPMODEL and (b) HYCYMODEL.

The sum of the distances between the upper bound and the lower one is smaller for TOPMODEL $\left(2.43 \times 10^{-1} \mathrm{~mm} / \mathrm{h}\right)$ than for HYCYMODEL $\left(2.62 \times 10^{-1} \mathrm{~mm} / \mathrm{h}\right)$. That is normal because the GLUE method tries to identify the uncertainty related to model calibration and TOPMODEL had fewer parameters to be calibrated than HYCYMODEL. However, the variance of the uncertainty interval of TOPMODEL is $1.05 \times 10^{-8}$ which is larger than that of HYCYMODEL, i.e., $7.80 \times 10^{-9}$. It occurs because, even though the uncertainty limits of TOPMODEL are narrower in the hydrograph recession, they are wider in the hydrograph peaks. This might be due to a higher sensitivity of TOPMODEL to the parameters related to runoff generation $\left(m, \ln T o\right.$ and $\left.S R_{M A X}\right)$. It seems that, for this series, HYCYMODEL is more sensitive to the parameter related to potential evapotranspiration $I G$, which has little influence on the discharge peaks.

The best set of the parameters, which resulted the highest $E$ values, for TOPMODEL and HYCYMODEL are in Table 3 and 4, respectively. The $E$ values for the best simulation of TOPMODEL and HYCYMODEL were 0.83 and 0.82 , respectively. These values show that both models possessed a similar efficiency for the Pequeno River catchment. The hydrographs produced with the best set of parameters with TOPMODEL and HYCYMODEL are in Figure 4 and 5. 
Table 3. TOPMODEL best set of parameters.

\begin{tabular}{cc}
\hline Parameter & Value \\
\hline$m(\mathrm{~m})$ & 0.0301 \\
$\ln T_{0}\left(\ln \left(\mathrm{m}^{2} \mathrm{~h}^{-1}\right)\right)$ & 0.11 \\
$T_{D}\left(\mathrm{~h} \mathrm{~m}^{-1}\right)$ & 86.3 \\
$R V\left(\mathrm{~m} \mathrm{~h}^{-1}\right)$ & 316 \\
$S R_{\text {MAX }}(\mathrm{m})$ & 0.00242 \\
\hline
\end{tabular}

Table 4. HYCYMODEL best set of parameters.

\begin{tabular}{cccc}
\hline Parameter & Value & Parameter & Value \\
\hline$C$ & 0.092 & $a_{2}$ & 0.377 \\
$D_{16}(\mathrm{~mm})$ & 28.5 & $S_{1}(\mathrm{~mm})$ & 1.265 \\
$D_{50}(\mathrm{~mm})$ & 79.8 & $S_{2}(\mathrm{~mm})$ & 0.845 \\
$K_{c}\left(\mathrm{~mm}^{2 / 5} \mathrm{~h}^{3 / 5}\right)$ & 51.2 & $E V I(\mathrm{~mm} / \mathrm{h})$ & 0.145 \\
$K_{h}\left(\mathrm{~mm}^{2 / 5} \mathrm{~h}^{3 / 5}\right)$ & 199.8 & $P_{t a}(\mathrm{~mm})$ & 24.66 \\
$K_{u}(\mathrm{~h})$ & 38.9 & $P_{t b}(\mathrm{~mm})$ & 38.24 \\
$K_{b}\left(\mathrm{~mm}^{9 / 10} \mathrm{~h}^{1 / 10}\right)$ & 266.7 & $I G$ & 13 \\
$a_{1}$ & 0.829 & $Q_{b c}(\mathrm{~mm} /$ day $)$ & 0.7 \\
\hline
\end{tabular}

The ratio between total runoff and total precipitation for this series was $0.79,0.81$ and 0.74 for the observed data, and the ones calculated with TOPMODEL and HYCYMODEL, respectively. Figure 4 shows the hydrograph separation with TOPMODEL. The contribution of baseflow to the total runoff is $77.7 \%$. In the hydrograph peaks, there is a large influence of surface flow and in the recession there is almost only baseflow. This occurs because the surface flow generation process is based on the soil saturation. According to Equation 4, the baseflow rises exponentially with the increase of the catchment saturation. The surface flow is calculated based on the rain that falls over the saturated area. Therefore, after the end of the precipitation event plus the contribution time of the entire saturated area, there is only a baseflow contributing for the total runoff plus the return flow from river channels.

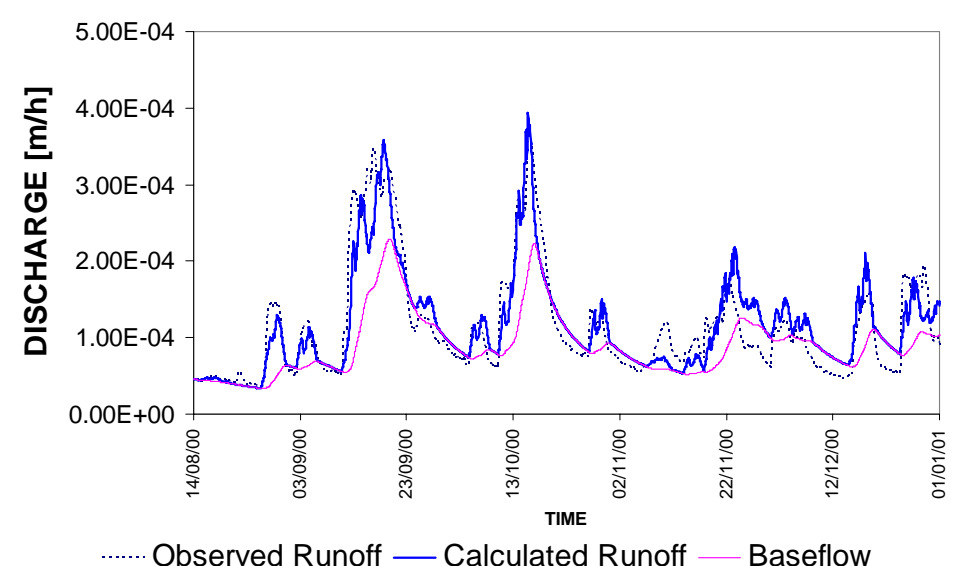

Figure 4. Hydrograph calculated with TOPMODEL. 
The hydrograph separation with HYCYMODEL is shown in Figure 5. The contribution of baseflow to the total runoff is $84.5 \%$. Different from the result with TOPMODEL, the simulation showed a larger contribution of baseflow in the hydrograph rising and the first declining part was composed by surface flow and baseflow. The surface flow generation process in HYCYMODEL is dependent not only on saturation but also on storage in two tanks. That is why there might be contribution of surface flow to the first declining part of the hydrograph.

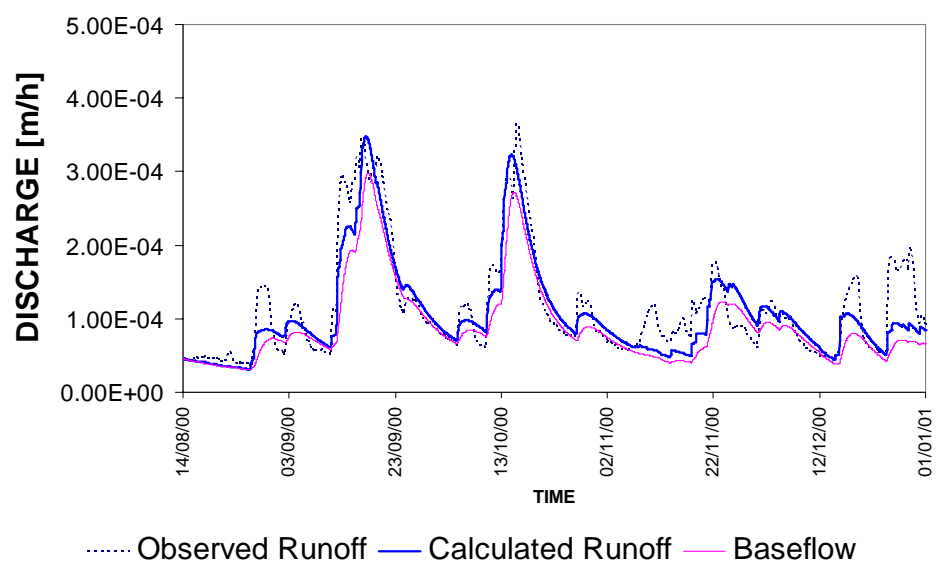

Figure 5. Hydrograph calculated with HYCYMODEL.

Both models simulated a large quantity of the baseflow to the total runoff and confirmed field observation results in different catchments such as reported by Sklash (1990). But there is a significant difference of these estimated quantities between the models. This difference is related to how they modeled the saturation process in the catchment. HYCYMODEL simulated a contribution of surface flow throughout all the declining parts of the hydrograph. The saturation and drainage processes (velocity and area) in catchment occur more quickly with TOPMODEL than HYCYMODEL (Figure 6).

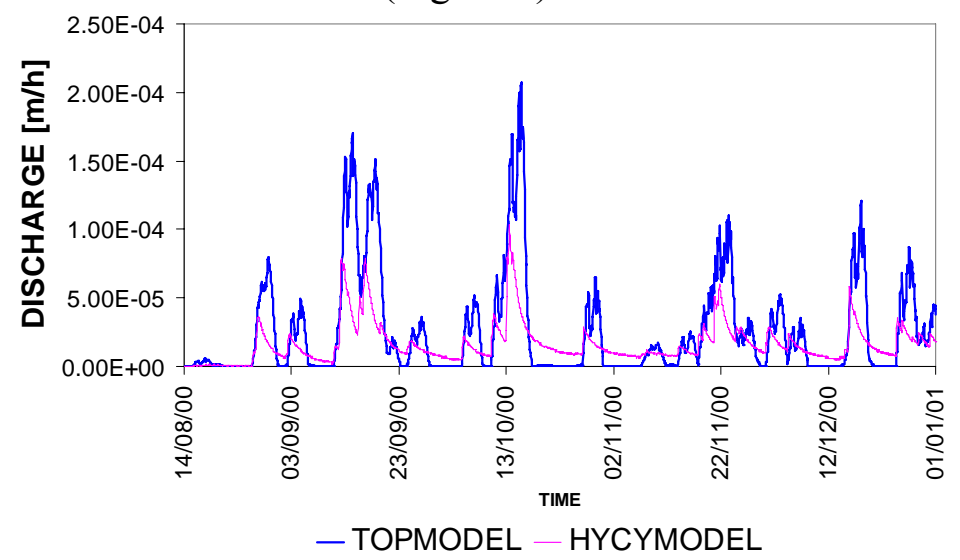

Figure 6. Surface Runoff calculated with TOPMODEL and HYCYMODEL.

\section{CONCLUSIONS}

This paper analyzed the rainfall-runoff process of the Pequeno River catchment with two different models, TOPMODEL and HYCYMODEL. The models were applied to a series of 3360 hourly observed data. The GLUE method was applied in order to determine uncertainty due to model calibration, and the uncertainty bounds of $5 \%$ and $95 \%$ were calculated for each model using the behavioral simulations $(E \geq 0.3)$. The uncertainty intervals are wider at the 
hydrograph peaks but narrower in the declining part with TOPMODEL than HYCYMODEL. It is probably due to a higher sensitivity of TOPMODEL to the parameters related to runoff generation.

For the hydrograph generation, TOPMODEL and HYCYMODEL presented a satisfactory and similar efficiency for the Pequeno River catchment with $E$ values equal to 0.83 and 0.82 respectively. Although the distributed model has some advantages such as saturated area mapping, the use of the lumped one is feasible to this catchment for hydrograph generation purposes

The total runoff ratio for the observed data, calculated with TOPMODEL and HYCYMODEL are $0.79,0.81$ and 0.74 , respectively. Compared to the observed data, HYCYMODEL seems to be overestimating water losses within this catchment.

In terms of hydrograph separation, both models simulated a large contribution of baseflow to the total runoff. However, there is a significant difference of these quantities between the models. TOPMODEL considered the catchment to saturate and drain faster than HYCYMODEL. It is hard to determine which model more accurately represents a real process of hydrograph separation in this catchment using only rainfall-runoff data. Hence, the use of tracer hydrograph separation should be realized to validate and improve the models.

\section{ACKNOWLEDGEMENTS}

The authors thank the CNPq for scholarship and Mr. Irani dos Santos (Federal University of Paraná) for hydrological database support.

\section{REFERENCES}

BEVEN, K. J.; BINLEY, A. The future of distributed models: model calibration and uncertainty prediction. Hydrological Processes, Chichester, v. 26, p. 279-298, 1992.

BEVEN, K. J.; KIRKBY, M. J. A physically based, variable contributing area model of basin hydrology. Hydrological Sciences Bulletin, Wallingford, v. 24, p. 43-69, 1979.

BEVEN, K. J.; LAMB, R.; QUINN, P.; ROMANOWICZ, R.; FREER, J. Topmodel. In: Computer Models of Watershed. Highlands Ranch: Water Resources Publication, 1995.p. $627-668$.

DOORENBOS, J.; PRUIT, W. O. Crop water requirements. Rome: FAO, 1977. p. 144.

DUNNE, T.; BLACK, R. D. Partial-area contributions to storm runoff in a small New England watershed. Water Resources Research, Washington, v.6, p. 1296-1311, 1970.

FUKUSHIMA, Y. A model of river flow forecasting for small forested mountain catchment. Hydrological Processes, Chichester, v. 2, p. 167-185, 1988.

FUKUSHIMA, Y.; SUZUKI, M. Hydrological cycle model for mountain watersheds and its applicatioin to the continuous 10 years recrds at intervals of both a day and an hour of Kiryu Watershed, Shiga Prefecture. Buletim University Forest-Kyoto Univ., v. 57, p. 162-185, 1986.

KOBIYAMA, M.; CHAFFE, P. L. B. Water balance in Cubatão-Sul river catchment, Santa Catarina, Brazil. Ambi-Água, Taubaté, v. 3, n. 1, p. 5-17, 2008. 
KOBIYAMA, M.; CHAFFE, P. L. B.; ROCHA, H. L.; CORSEUIL, C. W.; MALUTTA, S.; GIGLIO, J. N.; MOTA, A. A.; SANTOS, I.; RIBAS JUNIOR, U.; LANGA, R. Implementation of school catchments network for water resources management of the Upper Negro River region, southern Brazil. In: MAKOTO TANIGUCHI; WILIAM C. BURNETT; YOSHINORI FUKUSHIMA; MARTIN HAIGH; YU UMEZAWA. (ORG.). From Headwater to the Ocean: Hydrological changes and watershed management. London: Taylor \& Francis, 2009. In press. p. 151-157.

NASH, J. E.; SUTCLIFFE, J. V. River flow forecasting through conceptual models I: A discussion of principles. Journal of Hydrology, Amsterdam, v. 10, p. 282-290, 1970.

SANTOS, I. Modelagem geobiohidrológica como ferramenta no planejamento ambiental: estudo da bacia hidrográfica do Rio Pequeno, São José dos Pinhais - PR. 2001. 92f. Master's thesis (Soil Sciences) - Universidade Federal do Paraná, Curitiba, 2001.

SANTOS, I.; KOBIYAMA, M. Aplicação do TOPMODEL para determinação de áreas saturadas da bacia do Rio Pequeno, São José dos Pinhais, PR, Brasil. Ambi-Água, Taubaté, v. 3, n. 2, p. 77-79, 2008.

SILVA, R. V.; KOBIYAMA, M. Estudo comparativo de três formulações do TOPMODEL na bacia do Rio Pequeno, São José dos Pinhais, PR. Revista Brasileira de Recursos Hídricos, Porto Alegre, v. 12, p. 93-105, 2007.

SKLASH, M. G. Environmental isotope studies of storm and snowmelt generation. In: Process studies in Hillslope Hydrology. Chichester: John Wiley, 1990. p. 401-435.

SUZUKI, M.; KATO, H.; TANI, M.; FUKUSHIMA, Y. Throughfall, stemflow and rainfall interception in Kiryu experimental catchment (1) Throughfall and stemflow. J. Jap. For. Soc., Tokyo, v. 61, p. 202-210, 1979. 


ISSN = 1980-993X-doi:10.4136/1980-993X
www.agro.unitau.br/ambi-agua
E-mail: ambi-agua@agro.unitau.br
Tel.: (12) 3625-4116

\title{
Studies on contaminant transport at an industrial waste dumpsite of Bangalore, India (doi:10.4136/ambi-agua.61)
}

\author{
Syed Abu Sayeed Mohammed ${ }^{1}$; Maya Naik² ${ }^{2}$ Sanaulla Pathapalya Fakruddin³; \\ Zulfiqar Ahmed Mohammed Nazeer ${ }^{3}$ \\ ${ }^{1}$ Faculty of Civil Engineering, HKBK College of Engineering, \\ \#22/1, Nagawara, Bangalore 560045, India \\ Email: abubms@rediffmail.com \\ ${ }^{2}$ Faculty of Civil Engineering, BMS College of Engineering, \\ Bull Temple Road, Bangalore 560019, India \\ Email: snmcvbms@gmail.com \\ ${ }^{3}$ Faculty of Engineering Chemistry, HKBK College of Engineering, \\ \#22/1, Nagawara, Bangalore 560045, India \\ Email: sanahkbk@rediffmail.com,zulfi_chem@yahoo.com
}

\begin{abstract}
Industrialization and urbanization has produced various types of wastes that sometimes are dumped in low-lying areas without proper treatment and engineering controls. Bangalore district has more than 60 illegal dumpsites consisting of either municipal or industrial waste. Government records indicate that more than 1,500 industries are working at various industrial areas and other locations around the city. In the present study an attempt has been made to characterize the Bommasandra industrial area dump site located at the south of Bangalore. This dump site is 15 to 20 years old and spreads on an area of 12.7 acres. Around 60 to 70 industries of all nature are located around this dump site. A large number of soil samples were collected and after site characterization of soil properties, an attempt has been made to predict the transport behavior of selected chemical species using available mathematical models and a program based on MATLAB- 7 to study the migration properties of these selected chemical species as a function of time. Also a model provided by USEPA DRASTIC has been used. The DRASTIC Index found for this dumpsite was 146; therefore, one can conclude that the studied dumpsite is moderately vulnerable to pollutants. The migrating behavior of cations such as sodium, calcium and anions such as sulphate, chloride were considered. It was observed that cations are better retarded in comparison to anions. This was attributed to exchangeable chemical reactions.
\end{abstract}

Keywords: Dump site; industrial waste; municipal waste; diffusion; advection; retardation; modeling; MATLAB.

\section{Estudos de transporte de contaminantes em um depósito de lixo industrial em Bangalore, Índia}

\section{RESUMO}

A industrialização e urbanização têm produzido vários rejeitos que muitas vezes são despejados em áreas baixas sem tratamento adequado e sem engenharia de controle. $\mathrm{O}$ distrito de Bangalore tem mais de 60 lixões ilegais resultantes de rejeitos industriais ou municipais. Registros do governo apontam mais de 1.500 indústrias instaladas em diversos setores 
industriais e outros locais em torno da cidade. No presente estudo foi feita uma tentativa de caracterização do lixão da área industrial de Bommasandra, localizada no sul de Bangalore. Esse local de entulho tem de 15 a 20 anos e ocupa uma área de 12,7 acres. Cerca de 60 a 70 indústrias de diversas naturezas se localizam ao redor desse local de entulho. Um grande número de amostras de solo foi coletado para a caracterização do local e, após o conhecimento das propriedades do solo, foi feita uma tentativa de previsão do comportamento do transporte das espécies químicas selecionadas com base em modelos matemáticos disponíveis e em um aplicativo com base no MATLAB - 7 para modelar o processo de migração dessas espécies em função do tempo. Também um modelo disponibilizado pela USEPA DRASTIC foi usado. O Índice DRASTIC calculado para esse lixão foi 146; portanto, pode-se concluir que esse local de entulho é moderadamente vulnerável a poluentes. $\mathrm{O}$ comportamento de migração de cátions como sódio, cálcio e anions como sulfato, cloreto foi analisado. Foi observado que os cátions são mais retardados quando comparados aos anions. Isto foi atribuído às reações químicas desses elementos.

Palavras-chave: Lixão; rejeito industrial; lixo municipal; difusão; advecção; retardamento; modelagem; MATLAB.

\section{INTRODUCTION}

Nowadays, human kind's increasing mastery of natural law has at no doubt brought an increased life expectancy and a higher quality of life for more people than ever before. It has also brought the risk of global calamity and impairment of human health. Many of the environmental problems we are dealing with today are an accumulation of more than 200 years of managing residuals of our domestic and industrial output in ways we now know to be inappropriate. Past practices have resulted in a number of contaminated sites in proportion to the industrial output. We are now facing the cost of dealing with current and future production and use of products in such a way that they do not impair the environment or human health now or in the future (Wentz, 1995).

\subsection{Sources of ground water contamination}

The sources of ground water contamination can be from diffuse sources like deep percolation from intensively farmed fields or from point sources like septic tanks, garbage disposal sites, cemeteries, mine spoils and oil spills or other accidental entry of pollutants into the underground environment and also from line sources of poor quality water, like seepage from polluted streams or intrusion of salt water from oceans. Contaminant transport through compacted soil media is controlled by a variety of physical, chemical and biological processes. The physical processes include diffusion, advection and dispersion. The chemical process usually includes sorption, dissolution/precipitation, complexation, hydrolysis/substitution and oxidation. The biological process includes decay, etc.. Even with the implementation of waste reduction, recycling and transformation technologies, disposal of solid waste in landfills remains an important component of solid waste management strategy.

\subsection{Pollution vulnerability assessment using DRASTIC model}

Groundwater is one of the most valuable natural resources. During the last two decades groundwater quality has emerged as one of the most important environmental issues confronting much of the world's populace. Increasing evidence of groundwater contamination in recent years, coupled with uncertainties regarding long-term human health effects, has heightened pressure on public agencies to better manage groundwater resources. There is an 
urgent need for rapid surveys of groundwater utilization, aquifer pollution vulnerability and subsurface contaminant load.

\subsection{DRASTIC model parameters}

DRASTIC model is a groundwater pollution vulnerability assessment spatial deterministic model. This model consists of seven hydro geologic key parameters to classify vulnerability or pollution potential of an aquifer. The parameters are weighted with respect to their relative importance to the pollution potential of the aquifer.

The DRASTIC model acronym is taken from the parameters:
D Depth to water table
R Recharge
A Aquifer media
S Soil media
$\mathrm{T}$ Topography (slope)
I Impact of vadose zone
C Hydraulic conductivity of the aquifer material

This work envisages the use of hydrogeologic parameters, with proper ranking and weightage to yield suitable indices known as DRASTIC indices, a concept developed by USEPA (Gajendragad et al., 1990). DRASTIC is a numerical ranking system to assess groundwater pollution potential in any hydro geologic setting, which has been derived using DRASTIC factors. Each factor has been evaluated with respect to the other to determine the relative importance of each factor. The system consists of three significant parts namely weight, ranges and ratings.

\subsection{DRASTIC Index}

The DRASTIC Index is given by:

$$
\mathrm{DI}=\mathrm{D}_{\mathrm{r}} \mathrm{D}_{\mathrm{w}}+\mathrm{R}_{\mathrm{r}} \mathrm{R}_{\mathrm{w}}+\mathrm{A}_{\mathrm{r}} \mathrm{A}_{\mathrm{w}}+\mathrm{S}_{\mathrm{r}} \mathrm{S}_{\mathrm{w}}+\mathrm{T}_{\mathrm{r}} \mathrm{T}_{\mathrm{w}}+\mathrm{I}_{\mathrm{r}} \mathrm{I}_{\mathrm{w}}+\mathrm{C}_{\mathrm{r}} \mathrm{C}_{\mathrm{w}}
$$

where, $\mathrm{r}$ - rating and $\mathrm{w}$ - weight assigned. Once DRASTIC index is computed, it is possible to identify areas, which are more likely to be susceptible to ground water contamination relative to others.

Table 1. DRASTIC Index Number.

\begin{tabular}{ccccc}
\hline Drastic Index & Low & Moderate & High & Very High \\
\hline Values & $1-140$ & $141-180$ & $181-230$ & $>230$ \\
\hline
\end{tabular}

The higher the DRASTIC index, the greater the relative pollution potential. The DRASTIC index can be further divided into four categories: low, moderate, high, and very high. The sites with high and very high categories are more vulnerable to contamination and consequently need to be managed more closely. The weights assigned are relative, therefore a site with a low pollution potential may still be susceptible to groundwater contamination (Gajendragad et al. 1990). 


\subsection{Modeling}

Predicting the movement of fluids and contaminants in geologic systems is often carried out using theoretical models. In this approach, the processes under examination are simulated by a set of governing equations that are solved by analytical or numerical methods. At present, it is exceedingly difficult to obtain accurate field data that quantitatively describe contaminant transport and fate variables. Under these circumstances, model validation, a necessary precursor to routine model use, is problematic. For this reason, experimental data obtained under well defined conditions are fundamental for (i) assessing the predictive capabilities of existing theoretical models; and (ii) guiding the formulation, and parameterization, of improved predictive models. Ground water models are used to predict the migration pathway and concentrations of contaminants in groundwater (Shakelford and Daniel, 1991).

\subsection{Breakthrough curves}

Break through curves represent temporal variation in the concentration of a solute at the effluent end of a column of porous material. Using the experimental data breakthrough curves (i.e., a plot of the effluent liquid concentration $\mathrm{C}$ divided by the influent concentration $\mathrm{C}_{\mathrm{O}}$ as a function of pore volumes of flow or time) can be plotted. One pore volume of flow is equal to the volume of the void space in the soil. By measuring a breakthrough curve, the effective porosity of the soil is determined.

It can be expected that as the leachate invades the soil, none of the waste chemical will appear in the effluent at first. Then at some point, the invading leachate will make its way downstream through the soil column, and come out in more or less full strength. An instantaneous breakthrough of the waste liquid never occurs. The breakthrough is always gradual because the invading leachate mixes with the remnant soil water through a process called mechanical dispersion.

Many of the waste constituents in the leachate are attenuated or retarded by the soil. For example, with no retardation or attenuation, breakthroughs would occur at $\mathrm{C} / \mathrm{C}_{\mathrm{o}}$ of 0.5 at 1 pore volume of flow and below. Accordingly, if $\mathrm{C} / \mathrm{C}_{0}$ of 0.5 occurs at 1 pore volume of flow then the effective and total porosity would be equal (i.e., $n=n_{e}$ ). However, if $\mathrm{C} / \mathrm{C}_{\mathrm{o}}$ of 0.5 occurs at less than 1-pore volume of flow then the effective porosity would be reduced by the same percentage of total porosity (Daniel, 1993).

\subsection{Analytical solution to one dimensional contaminant transport equations}

Analytical methods are widely used for calculating the contaminant migration. The best known analytical solution for concentration $\mathrm{C}$ at time $\mathrm{t}$ and depth $\mathrm{z}$ beneath the surface of a barrier, which is assumed to be infinitely deep and subject to a constant surface concentration $\mathrm{C}_{\mathrm{o}}$ (Ogata and Banks, 1961).

The one dimensional approximate Ogata-Banks equation can be rearranged as:

$$
\frac{C}{C}-\frac{1}{2}\left[\operatorname{erfec}\left(\frac{1-D}{2 \sqrt{U D . / F L}}\right)\right]
$$

where, erfc $=1-\operatorname{erf}(\mathrm{x})$; erfc is the complimentary error function and $\operatorname{erf}(\mathrm{x})$ is the error function of the argument $x$ (Freeze and Cherry, 1979).

$\mathrm{v}=$ Darcy velocity in $\mathrm{cm} / \mathrm{sec}$

$\mathrm{L}=$ Length as in Equation 3

$\mathrm{C}=$ Effluent concentration in $\mathrm{mg} / \mathrm{l}$ 
$\mathrm{C}_{\mathrm{o}}=$ Influent concentration in $\mathrm{mg} / \mathrm{l}$

$\mathrm{x}=$ depth

$\mathrm{R}_{\mathrm{f}}=$ Retardation factor, where $\mathrm{R}$ is given by equation $\mathrm{R}_{\mathrm{f}}=\mathrm{v}_{\mathrm{gw}} / \mathrm{v}_{\mathrm{sp}} ; \mathrm{v}_{\mathrm{gw}}$ is velocity of ground water and; $\mathrm{v}_{\mathrm{sp}}$ is velocity of reactive species of concern.

However, for predicting the effective diffusion coefficient of ionic species of interest using column experiments, a modified form of the above equation is used. The column experiment results are commonly reported in terms of number of pore volume that have passed through packed soil column wherein one pore volume, is the cross sectional area of the column (A) times its length (L) times the porosity (n) i.e., ALn (Equation 3).

Total number of pore volume $\mathrm{U}$ is total discharge divided by value of one pore volume:

$$
\begin{aligned}
& \mathrm{U}=\mathrm{vnAt} / \mathrm{ALn}=\mathrm{vt} / \mathrm{L} \\
& \mathrm{J}_{0.84}=\left[(\mathrm{U}-1) / \mathrm{U}^{1 / 2}\right] \text { when } \mathrm{C} / \mathrm{C}_{\mathrm{o}}=0.84 \\
& \mathrm{~J}_{0.16}=\left[(\mathrm{U}-1) / \mathrm{U}^{1 / 2}\right] \text { when } \mathrm{C} / \mathrm{C}_{\mathrm{o}}=0.16
\end{aligned}
$$

where $\mathrm{J}_{0.84}, \mathrm{~J}_{0.16}$ are factors for simplification at 0.84 and 0.16 break through and Equation 2 is simplified and used as shown in Equation 6.

from which,

$$
\begin{gathered}
\mathrm{D}_{\mathrm{e}}=\mathrm{vL} / 8\left[\mathrm{~J}_{0.84}-\mathrm{J}_{0.16}\right]^{2} \\
\mathrm{D}_{\mathrm{e}}=\text { Effective diffusion co-efficient (units } \mathrm{cm}^{2} / \mathrm{sec} \text { ) }
\end{gathered}
$$

In addition to the above modified Ogata \& Bank's equation another expression for calculating the effective diffusion coefficient of ionic species of interest are given by Fried and Combarnous (1971) as follows:

$$
D_{e}=\frac{1}{8}\left[\frac{x-v t_{0.16}}{\sqrt{t_{0.16}}}-\frac{x-v t_{0.84}}{\sqrt{t_{0.84}}}\right]^{2}
$$

where $\mathrm{t}_{0.16}=$ time at $\mathrm{C} / \mathrm{C}_{\mathrm{o}}=0.16$ and $\mathrm{t}_{0.84}=$ time at $\mathrm{C} / \mathrm{C}_{\mathrm{o}}=0.84$.

The main objective of this work is to predict the vulnerability of the dumpsite using DRASTIC Model and with the available experimental data theoretical models are used to evaluate the behavior of some pollutants to similar soils.

\section{MATERIAL AND METHODS}

Bangalore district is situated in the heart of South Deccan of peninsular India, it is on a ridge top running through the middle of the Mysore plateau from west to east at an average elevation of 900 meters above sea level. Soil Samples were collected from the dumpsite located at Bommasandra industrial area on Hosur Road, Bangalore. Four soil samples were collected from four different stations. The soil samples were collected by open excavation from a depth of one meter from the natural ground. The area has a distinct red soil and the underlying geology is mostly granite and gneiss. The soil was dried and passed through the IS sieve size of 425 microns. The cation exchange capacity of the soil ranges from 18.5 meq/100g to $19.06 \mathrm{meq} / 100$ by Ammonium Acetate extraction method. Specific gravity test 
was conducted using a specific gravity bottle as per IS 2720 (Part III sec I) (Indian..., 1980). The liquid limit test of soil was determined by cone penetrometer method as per IS 2720 (Part V) (Indian... 1985a). Liquid limit of a soil is taken as the water content corresponding to 20 $\mathrm{mm}$ penetration, from a line drawn with respect to water content and penetration. The plastic limits of the soils were obtained as per standard method IS 2720 (Part V) (Indian... 1985a). Shrinkage limit test is conducted as per IS 2720-1972 (Part VI) (Indian... 1972). Grain-size distribution: The percentage of various sizes of particles in a given dry soil sample is found by a particle size analysis or mechanical analysis. The mechanical analysis is performed in two stages: sieve analysis and sedimentation analysis (Bureau of Indian Standards (BIS) which is a regulatory body established by the Government of India to standardize all testing methods and standard practices in the form of design codes. These standards are consistent with ASTM (American standard testing methods) and British standards. It takes into consideration Indian conditions which are unique due to geographical and climatic conditions). Chemical analyses of ground water were done according to standards methods for the examination of water and waste water. DRASTIC Index for the given dumpsite was calculated as enumerated above.

Applied Contaminant Transport Modeling is the first complete resource designed to provide clear coverage of the basic principles of solute transport simulation including the theory behind the most common numerical techniques for solving transport equations, and step-by-step guidance on the development and use of field-scale models. Analysis of contaminant transport has the application in the design of secure waste storage facilities, in the assessment of the effects of a wide range of industrial and mining activities on the groundwater system and evaluation of remedial works carried out to rectify ground water contamination.

To get an overview of the behavior of contaminants at the dumpsite for similar soil, disturbed samples have been used for column study (Maya , 2003). Column experiments were carried out in the Department of Civil Engineering of the Indian Institute of Science for various soils and for different chemical species. The diffusion coefficients used are literature diffusion coefficients given by Freeze and Cherry (1979) and experimental diffusion coefficients obtained from earlier work of these authors.

The column assembly consists of plexiglass of $32 \mathrm{~cm}$ length, $9.2 \mathrm{~cm}$ inner diameter, and $0.5 \mathrm{~cm}$ thick. The plexiglass is attached to the base plate which houses a filter paper and a porous stone. The soil specimen is pressed into plexiglass cylinder using a screw jack to ensure uniform compaction for the entire specimen. Once the soil sample was in place one or more set of porous stone and filter paper are placed at the top and capped with top plate. The influent line is connected at the bottom of the column assembly and effluent line at the top to collect the effluent. Contaminants of known concentration were passed through the column assembly and the effluent was collected and analyzed for their concentration, this was continued till breakthrough occurred.

The diffusion coefficients presented are expected to take into consideration not only tortuosity of soils but also various attenuation processes that occur while the ions migrate through soil. To verify the extent to which they represent various processes that occur through the soil, it is proposed to predict the breakthrough curves using these diffusion coefficients and soil properties and compare with actual breakthrough curves obtained experimentally. Literature and experimental curves are obtained considering both advection and diffusion as main processes for contaminant migration Freeze and Cherry (1979).

In the present study diffusion coefficient obtained by Ogata \& Bank's method is adopted and the contaminant transport behavior is studied by developing a computer program using MATLAB-7. 


\section{RESULTS AND DISCUSSION}

In the present study, an attempt is made to carry out characterization of contaminated dump site in Bommasandra industrial area, Bangalore. Analysis of both water and soil samples shows that the concentration of Sodium, Sulphate, Calcium and Chloride ions are found abundantly. Water samples collected from the nearby bore wells were analyzed for various water quality parameters. Results of the analysis show that many of the water quality parameters such as total hardness, chloride content, fluoride content, alkalinity, BOD, COD, $\mathrm{pH}$ are beyond the permissible limit. In almost all the water samples hardness is found to be in the range of 160 to $354 \mathrm{mg} / \mathrm{l}$ and this is attributed to presence of dissolved minerals such as Carbonates and bicarbonates of calcium, magnesium and also chloride, sulphate of calcium and sodium. The iron content is in the range of 0.78 to $0.90 \mathrm{mg} / 1$ which is higher than the prescribed limit; see details in Table 2, Table 3 and Table 4.

The DRASTIC Index of selected dumpsite is 146. The higher the DRASTIC index means the greater the groundwater pollution potential. The index number is a relative numerical value and is of value only with respect to other numbers generated by the same DRASTIC Index. Thus from the Drastic index number shown in Table 1 and calculated shown in Table 5 it can conclude that the selected dump site is moderately vulnerable to pollutants.

To model the transport of contaminants, mathematical models are available and can be used. In the present study an attempt was made to predict the migrating behavior of selected chemical species, which are abundantly available in both soil and water.

For design of soil liners compacted soil liners are always preferred. The permeability shall be less than $1.0 \mathrm{e}-7 \mathrm{~cm} / \mathrm{s}$. Hence based on extensive literature references, values of velocity are selected in the given range. For plotting the variation of relative concentration $(\mathrm{C} / \mathrm{C} 0)$ with time, experimental and literature values of diffusion coefficients, velocity $(\mathrm{v})$ are substituted for the ions considering thickness of the soil column and a computer program developed using MATLAB-7. From this program the variation of $\mathrm{C} / \mathrm{C} 0$ with time and the depth of migration with time are plotted using literature and experimental data for different chemical species. Also the comparison graphs are plotted between literature and experimental values as shown in Figure 1, Figure 2, and Figure 3. The migrating behavior of selected chemical species namely sodium, sulphate, calcium and chloride shows that sodium ions are retarded better when compared to other anions such as chloride and sulphate. This might be due to retention of sodium in place of exchangeable calcium present in the soil. Normally, sodium cannot be replaced by calcium. But in the presence of sulphate ion, calcium can form insoluble salt and is removed from ion complex of the clay. Then the sodium occupies the exchangeable position and hence it is retained.

The breakthrough curves, obtained by modeling, clearly show that the time required for sodium to reach relative concentration $(\mathrm{C} / \mathrm{C} 0=0.5)$ of 0.5 is 40 years without retardation and 48 years with retardation. For chloride it is observed that the breakthrough curve with retardation factor takes 44 years as compared to 38 years without retardation. Similarly for sulphate the curve with retardation factor takes more time to reach the breakthrough time of 48 years as compared to 37 years without retardation for sulphate. Hence, the effect of retardation factor and diffusion coefficient plays a vital role in the contaminant transport processes. 
Table 2. Results of grain size analysis.

\begin{tabular}{ccccc}
\hline $\begin{array}{c}\text { Station } \\
\mathbf{n}^{\mathbf{0}}\end{array}$ & $\begin{array}{c}\text { Clay } \\
\mathbf{( \% )}\end{array}$ & $\begin{array}{c}\text { Silt } \\
\mathbf{( \% )}\end{array}$ & $\begin{array}{c}\text { Sand } \\
\mathbf{( \% )}\end{array}$ & $\begin{array}{c}\text { Gravel } \\
\mathbf{( \% )}\end{array}$ \\
\hline 1 & 16 & 48 & 32 & 4 \\
2 & 18 & 55 & 26 & 1 \\
3 & 18 & 57 & 24 & 1 \\
4 & 18 & 52 & 29 & 1 \\
\hline
\end{tabular}

Table 3. The Physico-chemical properties of the soils used in the study.

\begin{tabular}{lrrrr}
\hline \multicolumn{1}{c}{ Property } & Station $\mathbf{1}$ & Station $\mathbf{2}$ & Station $\mathbf{3}$ & Station $\mathbf{4}$ \\
\hline Specific gravity (no units) & 2.51 & 2.53 & 2.51 & 2.54 \\
Liquid Limit (\%) & 35.75 & 35.88 & 35.30 & 35.70 \\
Plastic Limit (\%) & 22.01 & 20.23 & 21.0 & 21.65 \\
Shrinkage Limit (\%) & 15.49 & 15.19 & 16.69 & 16.55 \\
Max dry density $\left(\mathrm{g} / \mathrm{cm}^{3}\right)$ & 1.74 & 1.74 & 1.72 & 1.70 \\
Optimum moisture content (\%) & 27.1 & 27.6 & 28.1 & 27.3 \\
Cation exchange capacity (meq/100g) & 19.06 & 18.8 & 18.5 & 18.5 \\
Specific surface area $\left(\mathrm{m}^{2} / \mathrm{g}\right)$ & 48 & 50 & 44 & 44 \\
$\mathrm{pH}(\mathrm{no}$ units) & 5.64 & 5.16 & 5.53 & 5.21 \\
$\mathrm{EC}(\mathrm{dS} / \mathrm{m}) 1: 10$ & 0.083 & 0.094 & 0.092 & 0.089 \\
$\mathrm{OC}(\%)$ & 0.62 & 0.28 & 0.73 & 0.29 \\
$\mathrm{~K} \mathrm{~K}_{2} \mathrm{O}(\mathrm{Kg} / \mathrm{ha})$ & 74.55 & 21.30 & 79.88 & 73.98 \\
$\mathrm{Na}(\mathrm{ppm})$ & 29.0 & 31.0 & 23.0 & 33.0 \\
$\mathrm{~S}(\mathrm{ppm})$ & 06 & 08 & 07 & 05 \\
$\mathrm{Ca}(\mathrm{meq} / 100 \mathrm{~g})$ & 1.15 & 1.09 & 1.26 & 1.05 \\
$\mathrm{Mg}(\mathrm{meq} / 100 \mathrm{~g})$ & 1.02 & 0.97 & 0.98 & 0.86 \\
\hline
\end{tabular}

Table 4. Chemical analysis of ground water.

\begin{tabular}{lrrrrrr}
\hline \multicolumn{1}{c}{ Parameter } & Station 1 & Station 2 & Station 3 & Station 4 & Station 5 & Station 6 \\
\hline $\mathrm{pH}$ & 8.4 & 8.2 & 7.6 & 8.8 & 8.5 & 8.1 \\
Total Hardness (mg/l) & 160.0 & 314.0 & 248.0 & 268.0 & 173.0 & 354.0 \\
Calcium (mg/l) & 98.0 & 182.0 & 182.0 & 196.0 & 87.0 & 182.0 \\
Magnesium (mg/l) & 62.0 & 132.0 & 66.0 & 72.0 & 86.0 & 172.0 \\
Total Alkalinity (mg/l) & 184.0 & 140.0 & 139.0 & 159.0 & 167.0 & 134.0 \\
Chloride (mg/l) & 747.5 & 184.0 & 390.0 & 349.9 & 752.3 & 184.0 \\
Dissolved Oxygen & 9.9 & 7.6 & 7.7 & 8.3 & 9.7 & 7.5 \\
(mg/l) & & & & & & \\
Nitrate (mg/l) & 15.0 & 25.0 & 23.5 & 27.0 & 19.0 & 25.0 \\
Sodium (mg/l) & 53.0 & 65.0 & 68.0 & 74.0 & 58.0 & 69.0 \\
Potassium (mg/l) & 3.0 & 2.0 & 10.0 & 8.0 & 5.0 & 2.0 \\
Iron (mg/l) & 0.8 & 0.8 & 0.8 & 0.8 & 0.9 & 0.9 \\
Flouride (mg/l) & 0.7 & 0.7 & 0.6 & 0.8 & 0.8 & 0.6 \\
DO (mg/l) & 7.4 & 7.8 & 7.5 & 7.4 & 7.7 & 7.6 \\
BOD (mg/l) & 176.0 & 80.0 & 48.0 & 56.0 & 178.0 & 90.0 \\
COD $(\mathrm{mg} / \mathrm{l})$ & 367.2 & 412.4 & 357.9 & 447.8 & 381.3 & 422.6 \\
EC $(\mathrm{mS} / \mathrm{cm})$ & 1.80 & 2.09 & 2.17 & 2.12 & 1.85 & 2.02 \\
\hline
\end{tabular}


MOHAMMED, S. A. S.; NAIK, M.; SANAUlLA, P. F.; ZULFIQAR, A. M. N. Studies on contaminant transport, at an industrial waste dumpsite of Bangalore, India. Ambi-Agua, Taubaté, v. 3, n. 3, p. 55-66, 2008. (doi:10.4136/ambi-agua.61)

Table 5. DRASTIC Index number calculations.

\begin{tabular}{lcccc}
\hline Parameter & Range & Rating & Weight & Score \\
\hline Depth to water & $16-20 \mathrm{~m}$ & 3 & 5 & 15 \\
net Recharge & $41-60 \mathrm{~mm}$ & 6 & 4 & 24 \\
Aquifer media & Sand \& gravel & 8 & 3 & 24 \\
Soil media & Loam & 5 & 5 & 25 \\
Topography & $1 \%$ & 10 & 3 & 30 \\
Impact of Vadose zone & Silt and clay & 3 & 4 & 12 \\
Conductivity & $10-25 \mathrm{~m} /$ day & 8 & 2 & 16 \\
\hline Total & & & & 146
\end{tabular}

Table 6. Diffusion coefficients and retardation factors for different ions.

\begin{tabular}{lccc}
\hline Ions & $\begin{array}{c}\text { Diffusioncoefficients } \\
\text { (literature) in } \mathbf{c m}^{2} \text { / sec }\end{array}$ & $\begin{array}{c}\text { Diffusion coefficients } \\
\text { (experimental)in } \\
\mathbf{c m}^{2} / \mathbf{s e c}\end{array}$ & $\begin{array}{c}\text { Retardation } \\
\text { factors, no units } \\
\text { (experimental) }\end{array}$ \\
\hline Sodium & $4.6 \mathrm{e}-6$ & $7.995 \mathrm{e}-6$ & 1.3 \\
Sulphate & $2.0 \mathrm{e}-6$ & $4.136 \mathrm{e}-6$ & 0.5 \\
Sodium & $4.6 \mathrm{e}-6$ & $5.47 \mathrm{e}-5$ & 1.35 \\
Chloride & $5.9 \mathrm{e}-6$ & $4.872 \mathrm{e}-5$ & 1.4 \\
\hline
\end{tabular}

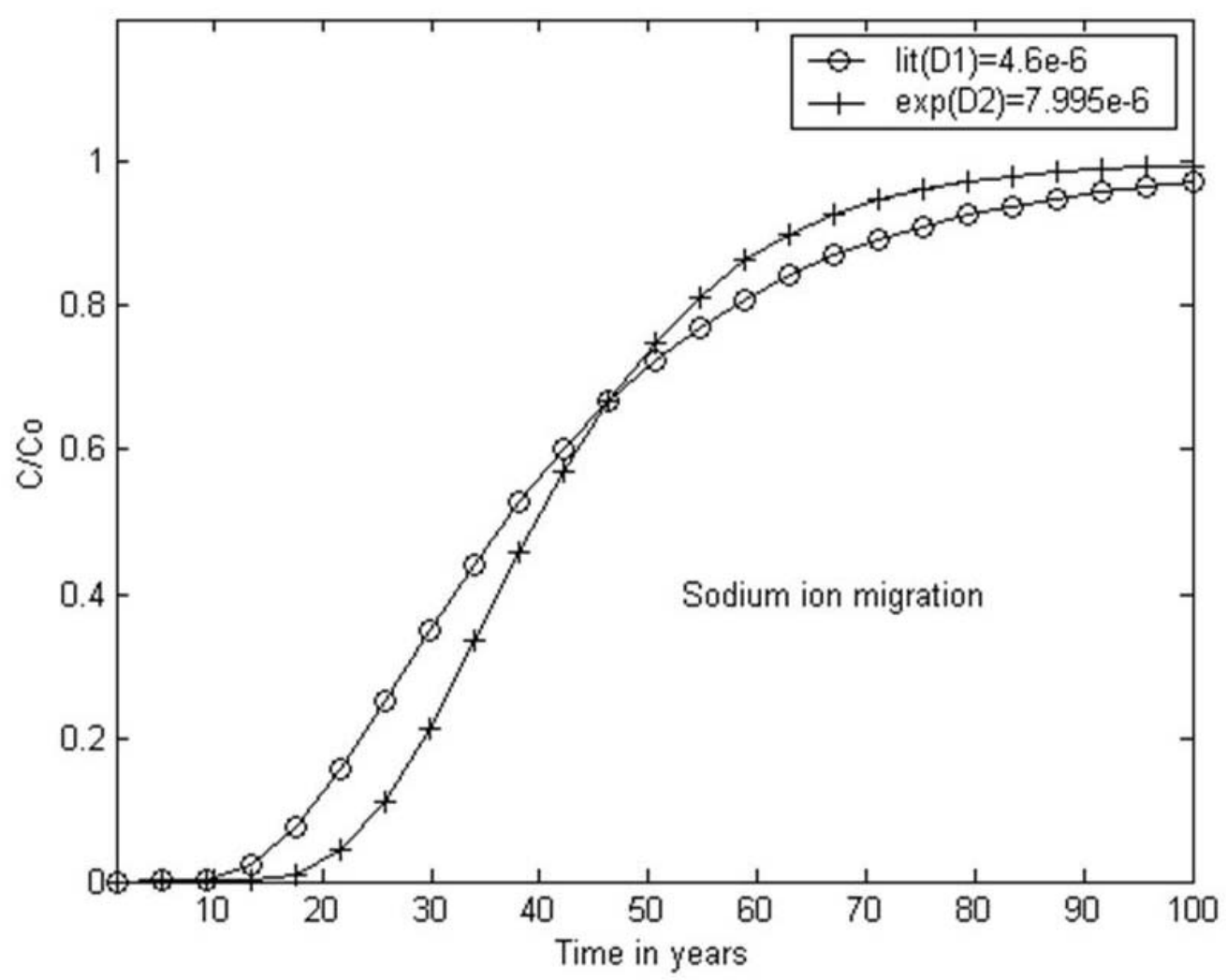

Figure 1. Variation of relative concentration of sodium ion with time for literature and experimental data. 
MOHAMMED, S. A. S.; NAIK, M.; SANAUlLA, P. F.; ZULFIQAR, A. M. N. Studies on contaminant transport, at an industrial waste dumpsite of Bangalore, India. Ambi-Agua, Taubaté, v. 3, n. 3, p. 55-66, 2008. (doi:10.4136/ambi-agua.61)

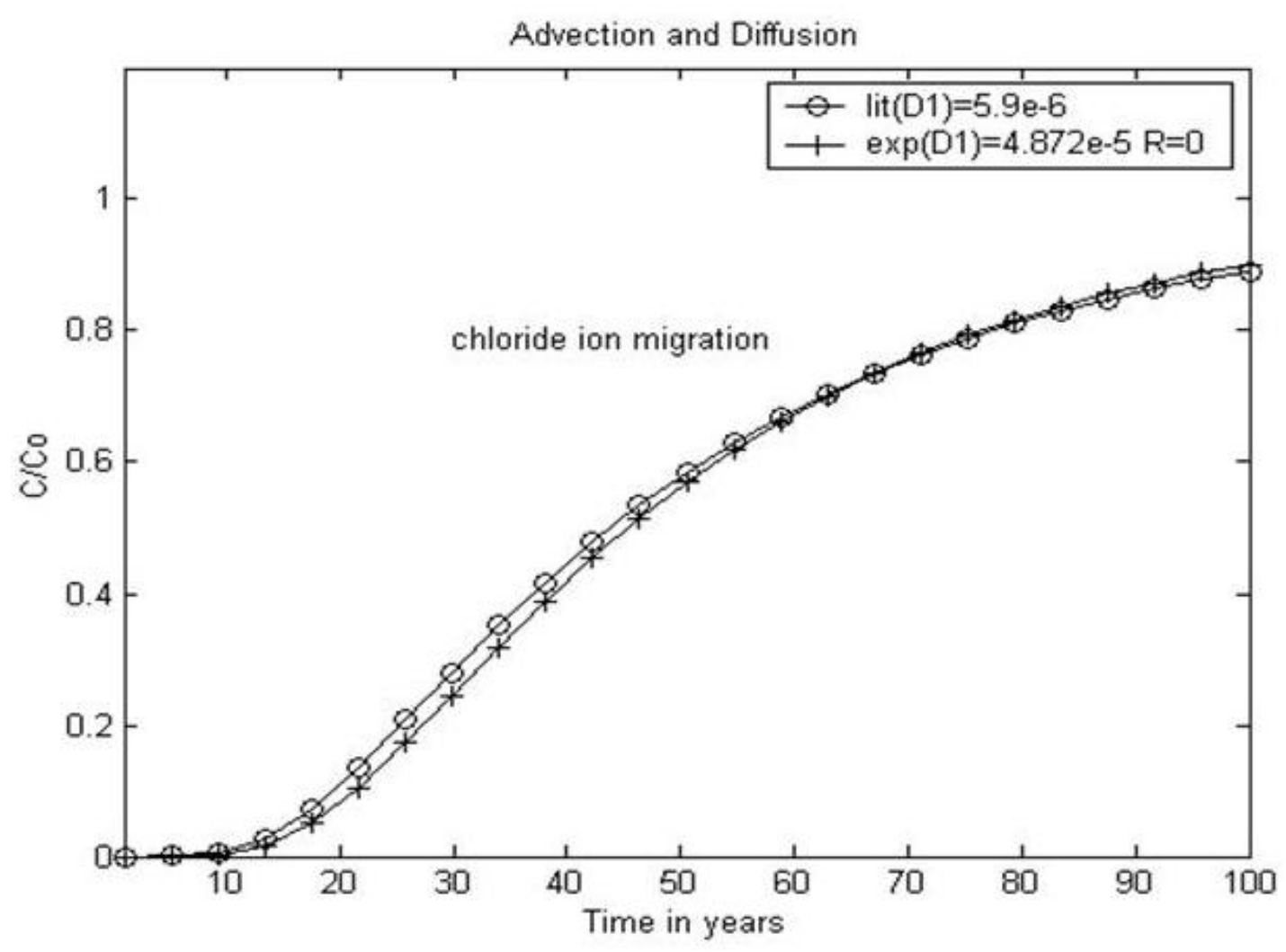

Figure 2. Variation of relative concentration of chloride with time for literature and experimental data.

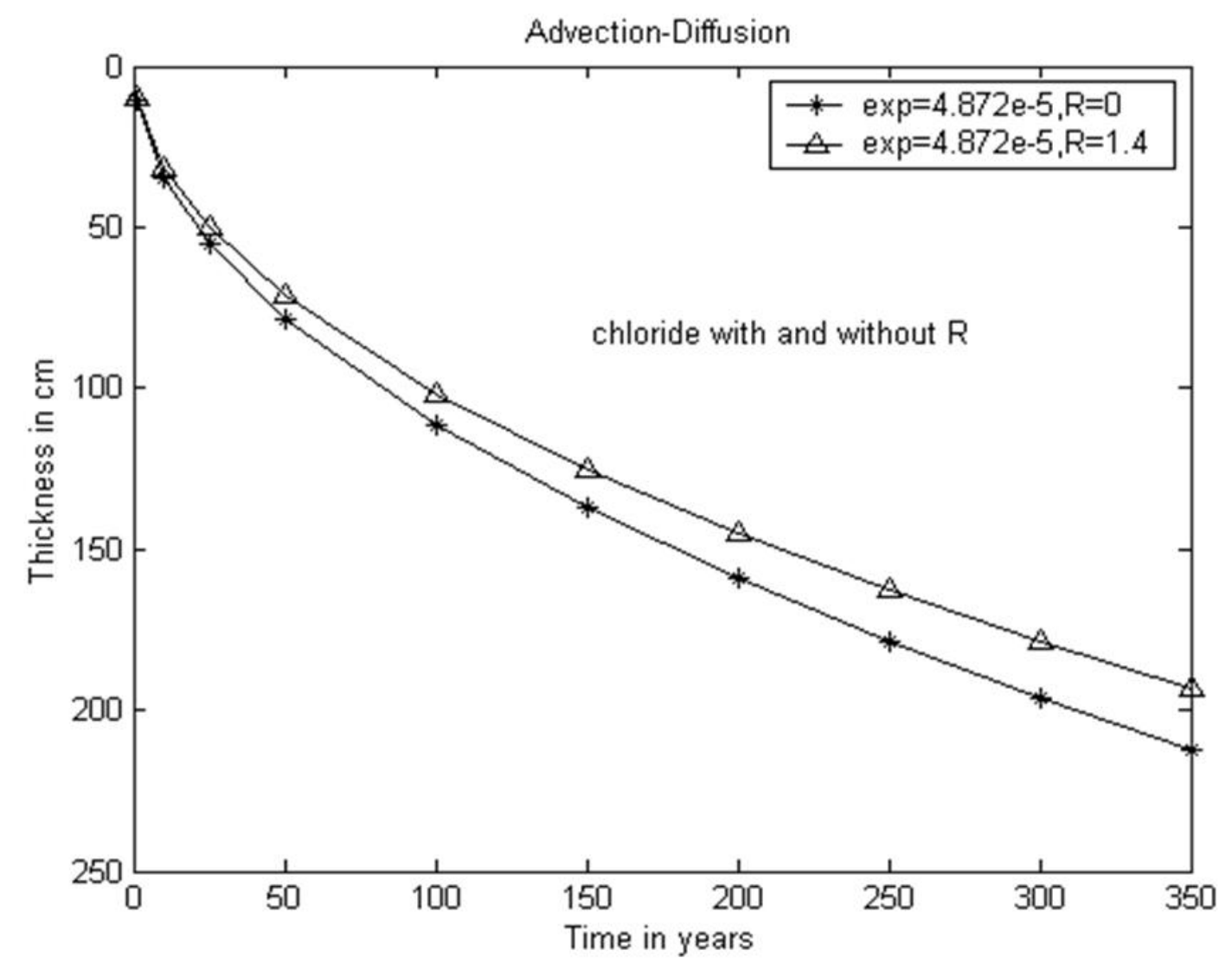

Figure 3. Depth of migration of chloride ion with time using experimental data with $\left(^{*}\right)$ and without retardation $(\Delta)$. 


\section{CONCLUSIONS}

In the present study, characterization of Bommasandra industrial area dumpsite has been carried out. The soil samples were collected from the contaminated site and analyzed for various parameters, the contaminant transport behavior was studied by developing a computer program using MATLAB-7. Based on the work carried out, and the following major conclusions are drawn:

A physico-chemical property of soil clearly shows that the major cations and anions present are sodium, calcium, chloride and sulphate ions, respectively. The concentrations of the above ions are found to be above the permissible limit.

The DRASTIC Index of selected dumpsite was 146, therefore, it can be concluded that the selected dump site is moderately vulnerable to pollutants.

The breakthrough curves obtained by modeling clearly show that the time required for sodium to reach relative concentration $(\mathrm{C} / \mathrm{C} 0=0.5)$ of 0.5 is 40 years without retardation and 48 years with retardation. For chloride it is observed that the breakthrough curve with retardation factor takes 44 years as compared to 38 years without retardation. Similarly for sulphate the curve with retardation factor takes more time to reach the breakthrough time of 48 years as compared to 37 years without retardation for sulphate. Hence, the effect of retardation factor and diffusion coefficient plays a vital role in the contaminant transport processes.

It has been found that the given dumpsite is moderately vulnerable to pollution presently, also by observing the theoretical model with the present state it can fairly predictable the fate of these contaminants in the future. The DRASTIC Index quantifies the present state of dumpsite and the model gives a picture of future to decision makers.

\subsection{Further scope of the study}

Since the site comes under moderately vulnerable to pollution potential, there is a possibility that pollutants are likely to be released from dumpsite and these migrate downwards through unsaturated zone to the water table and then laterally in the direction of the hydraulic gradient in the saturated zone. During the course of migration of pollutants the transport process is controlled by the variety of physical, chemical and biological processes. The contaminant transport process can be studied by conducting pilot plant studies at the contaminated site. A detailed study on characterization of contaminated dumpsite is a must because the nature of contaminants and nature of soil changes periodically. Hence there is a need for continuous monitoring of the quality of water from existent wells.

\section{ACKNOWLEDGEMENTS}

We would like to thank Prof. P.V. Sivapullaiah, Professor of Civil Engineering, Indian Institute of Science (IISc), Bangalore, Mr. B.T .Shivendra and Mrs. Indira R. for their help rendered in carrying out this work. We are highly indebted to the encouragement offered by our Honorable Administrator, Mr. Abdul Hameed S. A., and Principal, Dr. Chaitanya Kumar M.V. of HKBK College of Engineering. 


\section{REFERENCES}

DANIEL D. E. Geotechnical practices for waste disposal. London: Chapman and Hall, 1993.

FREEZE, R. A.; CHERRY, J. A. Groundwater. Englewood Cliffs: Prentice Hall, 1979. 604 p.

FRIED, J. J.; COMBARNOUS, M. A. Dispersion in porous media. Advances Hydroscience, v. 7, p. 169-282, 1971.

GAJENDRAGAD, M. R.; CHANDRAKANTA, R.; NYAMATHI, S. J. Assessment of ground water pollution susceptibility through drastic factor principle- a case study in west coast of India. International Conference on Calibration and Reliability in Groundwater Modelling, The Hague, P 220 -225, September 1990.

INDIAN STANDARDS INSTITUTION. Indian Standard Methods for Testing of Soils IS 2720: part 6, determination of shrinkage factors. New Delhi: Indian Standards Institution, 1972. p. $118-122$.

INDIAN STANDARDS INSTITUTION. Indian Standard Methods for Testing of Soils IS 2720: part 3, determination of specific gravity, section 1, fine grained soils. New Delhi: Indian Standards Institution, 1980. p. $65-69$.

INDIAN STANDARDS INSTITUTION. Indian Standard Methods for Testing of Soils IS 2720: part 5, determination of liquid limit and plastic limit. New Delhi: Indian Standards Institution, 1985a. p. $109-144$.

INDIAN STANDARDS INSTITUTION. Indian Standard Methods for Testing of Soils IS 2720: part 4, grain size analysis. New Delhi: Indian Standards Institution, 1985b. p. $73-91$.

JACKSON, M. L. Soil chemical analysis. New Delhi: Prentice Hall, 1967.

MAYA, N. Influence of diffusion coefficient and retardation factor in contaminant transport through soil liners. 2003. Thesis (Doctoral Degree in Civil Engineering) Indian Institute of Science, Bangalore, 2003.

OGATA, A.; BANKS, A. Solution of the differential equation of longitudinal dispersion in porous media. Fort Collins: US Geological Survey Professions, 1961. Paper 411 -A.

SHAKELFORD, C. D.; DANIEL, D. E. Diffusion in saturated soil: 1 Background, ASCE. Journal of Geotechnical Engineering, v. 177, n. 3, p. 467 - 484, 1991.

WENTZ, C. A. Hazardous waste management. New York: McGraw Hill, 1995. 


\begin{tabular}{|c|c|c|c|}
\hline & & $\begin{array}{c}\text { ISSN = } 1980-993 X-\text { doi:10.4136/1980-993X } \\
\text { www.agro.unitau.br/ambi-agua } \\
\text { E-mail: ambi-agua@agro.unitau.br } \\
\text { Tel.: (12) 3625-4116 }\end{array}$ & \\
\hline
\end{tabular}

\title{
Variabilidade espacial de vazão e pressão em subunidade de microaspersão com emissores usados e novos
}

(doi:10.4136/ambi-agua.62)

\author{
Wagner Walker de Albuquerque Alves ${ }^{1}$; José Dantas Neto²; José de Arimatea de \\ Matos $^{3}$; Carlos Alberto Vieira de Azevedo²; Vera Lúcia Antunes de Lima ${ }^{2}$ \\ ${ }^{1}$ Bolsista Pós-Doutorado-CNPq, UFCG/CTRN, Departamento de Engenharia Agrícola \\ E-mail: wagnerwaa@gmail.com \\ ${ }^{2}$ Professores do Departamento de Engenharia agrícola da UFCG \\ E-mail: \{cazevedo, zedantas, antunes\}@deag.ufcg.edu.br \\ ${ }^{3}$ Professor do Departamento de Ciências Ambientais, UFERSA \\ E-mail: jamatos@ufersa.edu.br
}

\section{RESUMO}

Este trabalho estudou em campo a distribuição espacial de vazão e pressão em subunidade irrigada por microaspersão, considerando emissores usados e novos. Os dados foram coletados em 28 pontos de emissão espaçados em $10 \times 18 \mathrm{~m}$. Os valores médios foram submetidos a teste de normalidade e também a uma análise geoestatística; a verificação da dependência espacial e da interpolação foi realizada pelo método da krigagem e as continuidades espaciais foram estudadas, construindo-se semivariogramas para as vazões e pressões da subunidade com microaspersores novos e usados. Verifica-se que os modelos variaram se o emissor era novo ou usado. O modelo matemático que melhor se ajustou à vazão dos microaspersores novos e usados foi, respectivamente, o exponencial e esférico; para a pressão o modelo foi o inverso da vazão, ou seja, esférico para os novos e exponencial para os usados. Os valores para os emissores usados do efeito pepita $(\mathrm{Co})$, patamar $(\mathrm{Co}+\mathrm{Cl}) \mathrm{e}$ alcance (Ao) foram de $1,0 \mathrm{~L} \mathrm{~h}^{-1}, 33 \mathrm{~L} \mathrm{~h}^{-1}$ e $218 \mathrm{~m}$ e de $0,43,137 \mathrm{kPa}$ e $58 \mathrm{~m}$, para vazão e pressão, respectivamente. O coeficiente de uniformidade de irrigação, o coeficiente de uniformidade do sistema e a eficiência de aplicação d’água aumentaram, respectivamente, em $11,9,10,58$ e 10,75\%, quando os emissores usados foram substituídos por novos. A distância máxima (alcance) onde os dados estimados de vazão e pressão se correlacionam espacialmente extrapolou o comprimento da linha de derivação para a vazão com microaspersores novos e usados e para a pressão só com microaspersores novos. O efeito pepita para a pressão no sistema foi menor quando se trocou os microaspersores usados por novos, acontecendo o inverso para a vazão. Houve um aumento tanto da pressão como da vazão quando se trocou os microaspersores usados por novos.

Palavras-chave: microaspersor; geoestatística; avaliação.

\section{Spatial variability of discharge and pressure in subunit of microsprinkler irrigation with used and new emitters}

\begin{abstract}
This work studied in field the spatial distribution of discharge and pressure in subunit irrigated by microsprinkler, considering used and new emitters. The data were collected in 28 emission points spaced in $10 \times 18 \mathrm{~m}$. The mean values were submitted to normality test and
\end{abstract}


also to a geostatistical analysis; the verification of the spatial dependence and of the interpolation was accomplished by the method of krigagem and the spatial continuities were studied by means of semivariograms for the discharges and pressures of the subunit with new and used microsprinklers. It is verified that the models varied if the emitter was new or used. The mathematical model that better adjusted to the discharge of the new and used emitters was, respectively, exponential and spherical; for the pressure, the model was the inverse of the discharge, that is, spherical for new emitters and exponential for used ones. The values for the used emitters of the nugget effect $(\mathrm{Co})$, landing $(\mathrm{Co}+\mathrm{Cl})$ and reach $(\mathrm{Ao})$ were of $1.0 \mathrm{~L} \mathrm{~h}^{-1}$, $33 \mathrm{~L} \mathrm{~h}^{-1}$ and $218 \mathrm{~m}$ and of $0.43,137 \mathrm{kPa}$ and $58 \mathrm{~m}$, for discharge and pressure, respectively. The coefficient of irrigation uniformity, the coefficient of uniformity of the system and the water application efficiency increased, respectively, in 11.9, 10.58 and $10.75 \%$, when the used emitters were substituted by new ones. The maximum distance (reach) where the estimated data of discharge and pressure are spatially correlated extrapolated the length of the derivation line for the discharge with new and used microsprinklers and for the pressure only with new microsprinklers. The nugget effect for the pressure in the system was smaller when it was changed the used microasprinklers by new ones, the inverse was observed for the discharge. There was an increase in pressure as well as in discharge when the used microsprinklers were changed by new ones.

Keywords: microsprinkler; geostatistics; evaluation.

\section{INTRODUÇÃO}

Após a implantação de um projeto de irrigação, o produtor rural deve ser orientado para que possa obter o máximo de rendimento do sistema em uso. Isso implica não apenas estabelecer a adequação do momento de se efetuar as irrigações e da lâmina de água a ser aplicada, mas, também, uma uniformidade na aplicação da água desejável. Keller e Bliesner (1990) comentam que é recomendável, após a instalação de um sistema de irrigação, procederam-se testes de campo no intuito de se verificar a adequação da irrigação que foi projetada, para recomendar, caso haja necessidade, ajuste no manejo. Esses procedimentos visam maximizar a eficiência do sistema de irrigação.

De acordo com Keller e Karmeli (1974), apesar das inúmeras vantagens apresentadas, existem problemas na irrigação localizada, dentre os quais se destaca a obstrução dos emissores. Ela é causada por materiais orgânicos em suspensão, por deposição química e por partículas minerais. Essa obstrução afeta a uniformidade de aplicação d’água, que depende fundamentalmente das vazões dos emissores do sistema. À medida que se prolonga o tempo de uso dos equipamentos de um sistema de irrigação no decorrer do ciclo da cultura, aumenta a possibilidade de obstrução dos orifícios, diminuindo, conseqüentemente, a uniformidade com que a água é distribuída no campo, o que afeta o rendimento da cultura; necessita-se, então, de uma avaliação periódica da uniformidade de distribuição da água.

A uniformidade da irrigação tem efeito no rendimento das culturas, sendo considerada um dos fatores mais importantes no dimensionamento e na operação de sistemas de irrigação. Baixa uniformidade resulta em alto consumo de água e energia. As causas da desuniformidade de aplicação de água nos sistemas de irrigação localizados são as seguintes: diferenças de pressão que se produzem na rede devido às perdas de carga e à irregularidade da topografia do terreno; insatisfatória uniformidade de fabricação dos emissores, devido ao inadequado controle de qualidade; número de emissores por planta; variação das características hidráulicas do emissor, ao longo do tempo, devido a possíveis obstruções e/ou 
envelhecimento; temperatura da água; efeito do vento; e variação de fabricação dos reguladores de pressão, quando existirem (Abreu et al., 1987). A utilização de sistemas de irrigação mais eficientes é uma busca constante na agricultura irrigada, pois existe tendência de aumento no custo da energia e de redução da disponibilidade hídrica dos mananciais (Barreto Filho et al., 2000).

Segundo Boman (1989), a uniformidade é um indicador da igualdade (ou desigualdade) das taxas de aplicação da água. Uniformidade alta é importante para irrigação em terras arenosas, onde a redistribuição lateral da água é limitada. Excessos de aplicação de água nesses solos resultam freqüentemente em lâmina percolada e lixiviação de nutrientes para fora da zona radicular. A uniformidade elevada pode ser especialmente desejável para fertirrigação ou quimigação, visto que as aplicações de nutrientes ou outros produtos químicos não serão mais uniformes do que a distribuição de água.

Em agricultura irrigada, os parâmetros envolvidos, sejam relativos à água, ao solo, à planta ou à atmosfera, exibem um comportamento variável no espaço e no tempo, requerendo uma boa análise estatística para interpretação dos dados. Uma análise exploratória adequada dos dados constitui o ponto de partida para observar o comportamento das variáveis de interesse, o que pode ser feito por meio de técnicas estatísticas descritivas gerais e espaciais. Essa análise servirá de base para orientar na decisão de se assumir algum tipo de correlação espacial dos dados, o que é de fundamental importância nas análises geoestatísticas (Queiroz et al., 1997).

Ante o exposto, o objetivo deste trabalho foi avaliar a variabilidade espacial da vazão e pressão em uma subunidade de irrigação por microaspersão com emissores novos e usados, empregando técnicas da estatística clássica e da geoestatística na área irrigada.

\section{MATERIAL E MÉTODOS}

O trabalho foi realizado numa área cultivada com graviola (Annona muricata L.), do perímetro irrigado de São Gonçalo, no município de Sousa, PB, cujo clima é do tipo BSh, semi-árido quente. A temperatura média anual é de $27,8^{\circ} \mathrm{C}$, com precipitação média anual de $894 \mathrm{~mm}$, concentrada nos meses de janeiro a maio. A umidade relativa média do ar é de $58 \%$, e a velocidade média do vento é de $2,5 \mathrm{~m} \mathrm{~s}^{-1}$.

Num sistema de irrigação por microaspersão, instalado há dois anos com a cultura da graviola, com um espaçamento de $6,0 \times 5,0 \mathrm{~m}$, utilizando-se um microaspersor por planta, avaliou-se a subunidade com linha terciária em PVC de $144 \mathrm{~m}$ na qual eram conectadas as laterais de polietileno com $30 \mathrm{~m}$, possuindo 7 microaspersores espaçados em $5 \mathrm{~m}$ numa área irrigada de $4320 \mathrm{~m}^{2}$. O microaspersor autocompensante usado era da marca EINDOR 86, e de acordo com as especificações do fabricante, possuía uma vazão de $50 \mathrm{~L} \mathrm{~h}^{-1}$ a uma pressão de serviço entre 150 a $200 \mathrm{kPa}$. Foram escolhidos 28 microaspersores, dentro da subunidade de irrigação, sendo espaçados na direção da tubulação lateral em 10 m e na direção da terciária em 18 m (Figura 1), onde se determinou a vazão e a pressão de cada emissor em campo, utilizando para isso uma proveta de $1000 \mathrm{~mL}$, como coletor da água, um cronômetro e um manômetro digital. Durante um período de 2 horas, o sistema de irrigação era mantido ligado, e a coleta d'água era feita por um tempo de $30 \mathrm{~s}$, obtendo-se médias de três repetições para cada ponto. Após a coleta dos dados com os microaspersores usados, permutou-se por novos, realizando-se outro ensaio. 


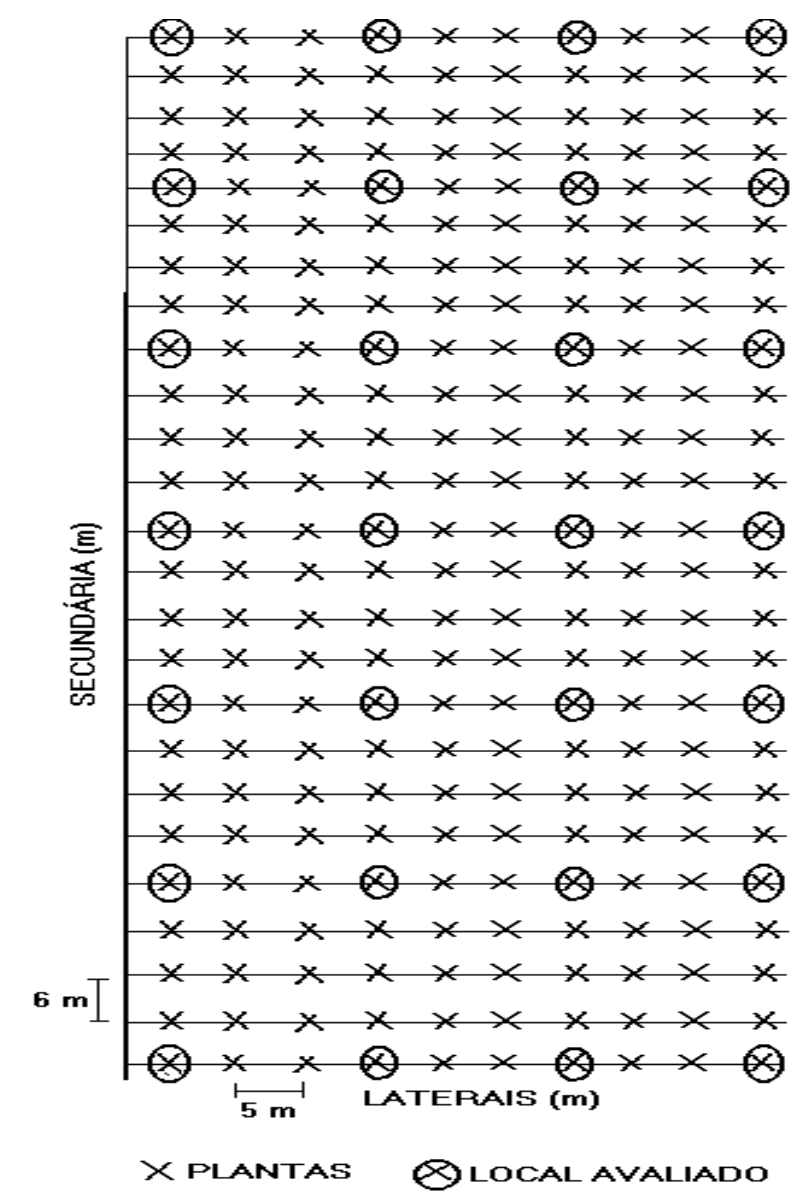

Figura 1. Esquema dos pontos de coleta de dados na subunidade de irrigação.

A partir dos resultados obtidos na subunidade, determinou-se a uniformidade de emissão, segundo as metodologias de Merrian e Keller (1978) e ASAE (1996). Determinou-se a variação de pressão e vazão ao longo das linhas laterais e das secundárias, utilizando-se as seguintes equações:

$$
\begin{aligned}
& \Delta Q=\frac{\text { Qmáx }- \text { Qmín }}{\text { Qmáx }} * 100 \\
& \Delta P=\frac{\text { Pmáx }- \text { Pmín }}{\text { Pmáx }} * 100
\end{aligned}
$$

em que:

$\Delta \mathrm{P} \quad$ - variação de pressão, $\%$

Pmáx - valor máximo de pressão, $\mathrm{kPa}$

Pmín - valor mínimo de pressão, $\mathrm{kPa}$

$\Delta \mathrm{Q}$ - variação de vazão na lateral, \%

Qmáx - valor máximo de vazão, $\mathrm{L} \mathrm{h}^{-1}$

Qmín - valor mínimo de vazão, $\mathrm{L} \mathrm{h}^{-1}$ 
A partir dos valores de vazão e de pressão encontrados na subunidade, determinou-se a uniformidade de irrigação, segundo as metodologias:

\subsection{Metodologia de Merrian e Keller (1978)}

$$
C U=100\left(\frac{q_{25 \%}}{q_{\text {med }}}\right)
$$

em que:

CU - coeficiente de uniformidade de irrigação da subunidade avaliada em campo, \%

$\mathrm{q}_{25 \%}$ - média de $25 \%$ do total de microaspersores com as menores vazões $\left(\mathrm{L} \mathrm{h}^{-1}\right)$

$\mathrm{q}_{\text {med }}$ - média das vazões coletadas nos microaspersores na subunidade $\left(\mathrm{L} \mathrm{h}^{-1}\right)$

$$
C U p=100 *\left(\frac{P_{25 \%}}{P M}\right)^{X}
$$

em que:

CUp - coeficiente de uniformidade de pressão, \%

$\mathrm{PM}$ - pressão média da subunidade $(\mathrm{kPa})$

$\mathrm{P}_{25 \%}$ - pressão média de $25 \%$ das pressões mais baixas dentro da subunidade avaliada, $\mathrm{kPa}$

$\mathrm{x}$ - expoente de descarga do emissor, calculado pela Eq. 5:

$$
x=\frac{\log \left(\bar{q}_{1} / \bar{q}_{2}\right)}{\log \left(h_{1} / h_{2}\right)}
$$

em que:

$\mathrm{q}_{1}$ - média da vazão de quatro emissores obtida com a menor pressão, $\mathrm{h}_{1}$

$\mathrm{q}_{2}$ - média da vazão de quatro emissores obtida com a maior pressão, $\mathrm{h}_{2}$

O fator de correção das vazões foi determinado mediante a seguinte equação:

$$
F C V=\left(\frac{P_{25 \%}}{P M_{\text {mín }}}\right)^{X}
$$

em que:

FCV - fator de correção das vazões

$\mathrm{PM}_{\text {min }}$ - média de todas as pressões mínimas da subunidade, $\mathrm{kPa}$

$\mathrm{P}_{25 \%}$ - pressão média de $25 \%$ das pressões mais baixas da subunidade, $\mathrm{kPa}$

$\mathrm{x}$ - expoente de descarga do emissor

A uniformidade de irrigação do sistema (CUS) foi dada pela Eq. 7:

$$
C U S=C U^{*} F C V
$$

A eficiência de aplicação (EA) sob irrigação completa, segundo Merrian e Keller (1978), foi estimada por:

$$
E A=0,9 * C U
$$




\subsection{Metodologia da ASAE (1996)}

A avaliação da uniformidade de irrigação, segundo a ASAE (1996), é baseada no método de estimação de uniformidade em campo, proposto por Bralts e Kesner (1983), fundamentado no coeficiente de uniformidade estatístico. Selecionou-se uma subunidade de irrigação que estava funcionando em concordância com as condições normais de trabalho e avaliou-se a uniformidade de aplicação de água dentro da subunidade a partir da Eq. 9:

$$
C U E=(1-C V T) * 100
$$

em que:

CUE - coeficiente de uniformidade estatístico de irrigação

CVT - coeficiente de variação total de vazão na subunidade

Para a determinação do coeficiente de variação de vazão total (CVT) para a subunidade, foi usada a seguinte equação:

$$
C V T=\frac{S_{q}}{q_{\text {med }}}
$$

em que:

$\mathrm{S}_{\mathrm{q}} \quad$ - desvio padrão da vazão dos emissores $\left(\mathrm{L} \mathrm{h}^{-1}\right)$

$\mathrm{q}_{\text {med }}$ - vazão média dos emissores na subunidade $\left(\mathrm{L} \mathrm{h}^{-1}\right)$

Com as pressões medidas na subunidade, obteve-se um coeficiente de variação da vazão por causas hidráulicas $(\mathrm{CVH})$, pela expressão:

$$
C V H=\frac{S_{h}}{h_{\text {med }}}
$$

em que:

$\mathrm{S}_{\mathrm{h}}$ - desvio padrão das pressões medidas $(\mathrm{kPa})$

$\mathrm{h}_{\text {med }}$ - pressão média dos emissores na subunidade $(\mathrm{kPa})$

O coeficiente da variação do desempenho dos emissores (CVE) foi dado por:

$$
C V E=\sqrt{C V T^{2}-x^{2} * C V H^{2}}
$$

Por meio da estatística descritiva determinaram-se medidas de posição: média aritmética e a mediana amostral e as medidas de dispersão, variância, desvio-padrão amostral e coeficiente de variação. Esse procedimento foi importante para o conhecimento preliminar da distribuição da vazão e pressão no sistema de irrigação. Com um total de 28 pontos amostrais do conteúdo de água no solo, analisaram-se a estrutura e a dependência espacial, pela análise geoestatística e pelos semivariogramas experimentais (Andrade, 2002), em que a dependência espacial é definida pelo alcance (Ao), o erro cometido devido à distância de amostragem é definido pelo efeito pepita (Co), o ponto onde toda semivariância da amostra dos dados é de influência aleatória é medido pela variância estrutural ou espacial $(\mathrm{Cl})$, e o patamar $(\mathbf{C})$ que corresponde, aproximadamente, ao valor da variância total da variável em estudo, é obtido por $\mathrm{C}=(\mathrm{Co}+\mathrm{Cl})$. A dependência espacial entre as observações pode ser expressa pelo semivariograma, estimado pela seguinte expressão. 


$$
\bar{y}(h)=\frac{1}{2 N(h)} \sum_{i=1}^{N(h)}\left[z\left(x_{i}\right)-z\left(x_{i}+h\right)\right]^{2}
$$

em que:

$\bar{y}(h)$ - valor da semivariância estimado para a distância de separação (h) entre as medidas.

$\mathrm{Z}\left(\mathrm{x}_{\mathrm{i}}\right)$ - valor da variável para a posição xi não estimado (verdadeiro).

$\mathrm{Z}\left(\mathrm{x}_{\mathrm{i}}+\mathrm{h}\right)$ - valor da mesma variável na posição $\mathrm{x}_{\mathrm{i}}+\mathrm{h}$ em qualquer direção.

$\mathrm{h}$ - distância de separação entre as medidas.

$\mathrm{N}(\mathrm{h})$ - número de pares experimentais de dados medidos de $\mathrm{Z}\left(\mathrm{x}_{\mathrm{i}}\right)$ e $\mathrm{Z}\left(\mathrm{x}_{\mathrm{i}}+\mathrm{h}\right)$.

O gráfico de $\bar{y}(h)$ versus os valores correspondentes de h é chamado semivariograma, sendo, então, uma função do vetor $\mathrm{h}$, e, portanto depende tanto de sua magnitude como da direção de h. Modelos matemáticos devem ser ajustados aos semivariogramas, os quais permitem visualizar a natureza da variação espacial da vazão e pressão no sistema de irrigação, além de serem necessários para outras aplicações, como, por exemplo, krigagem. Para se analisar o grau de dependência espacial das variáveis em estudo, utilizou-se à classificação de Cambardella et al. (1994) em que são considerados de dependência espacial forte os semivariogramas que têm efeito pepita $\leq 25 \%$ do patamar, de dependência espacial moderada quando o efeito pepita está entre 25 a $75 \%$ e de dependência espacial fraca, quando o efeito pepita é $>75 \%$.

Foi construído o semivariograma experimental e definido o modelo de ajuste, de modo que a curva que melhor se ajustou aos pontos obtidos representa a magnitude, alcance e a intensidade da variabilidade espacial da vazão e pressão no sistema de irrigação. A decisão pelo melhor modelo e respectivos coeficientes foi tomada com base na validação cruzada.

Existindo a dependência espacial, as estimativas para pontos não observados são obtidas pela técnica da krigagem. Essa é uma técnica de interpolação não tendenciosa, que possui variância mínima, sendo cada estimativa obtida pelo cálculo de uma média ponderada de um conjunto de observações ao redor de uma vizinhança (Andrade, 2002) em que o valor de $\bar{Z}\left(x_{0}\right)$, associado à posição $\mathrm{x}_{0}$, pode ser obtido pela expressão.

$$
\bar{Z}\left(x_{0}\right)=\sum_{i=1}^{N} \lambda_{i} Z\left(x_{i}\right)
$$

Sendo: $\bar{Z}\left(x_{0}\right)$ valores estimados da variável em estudo, $\mathrm{x}_{0}$ o ponto a ser estimado, $\mathrm{N}$ o número de vizinhos utilizado na estimativa $\bar{Z}\left(x_{0}\right), \lambda_{\mathrm{i} \text { os }}$ pesos ponderados associados a cada valor medido de $\bar{Z}\left(x_{0}\right)$.

Por meio de técnicas de interpolação da krigagem foram construídos os mapas de isolinhas e de superfície em três dimensões (3D) representativos da distribuição espacial da vazão e pressão nos emissores, com o auxilio do programa Surfer 7.0 (Golden Software, 2001) e dos parâmetros de cada modelo de semivariogramas ajustados aos dados de vazão e pressão nos emissores, utilizando-se o software GS+ "Geoestatístics for Environmental Sciences" (GS+, 2000). 


\section{RESULTADOS E DISCUSSÃO}

De acordo com os resultados da avaliação de campo (Tabela 1), a subunidade com microaspersores usados apresentou uma baixa uniformidade de distribuição de água e, conseqüentemente, uma baixa eficiência de irrigação, devido à baixa pressão observada no sistema, provocando uma grande variação de vazão nos emissores ao longo das linhas laterais. $\mathrm{Na}$ permuta de emissores usados por novos, foi possível observar que o valor de pressão média aumentou, passando de 112 para $122 \mathrm{kPa}$, proporcionando também um aumento de vazão de 32,9 para $36,9 \mathrm{~L} \mathrm{~h}^{-1}$, mesmo assim permanecendo baixos os valores de pressão e vazão da subunidade. As variações de pressão e vazão na subunidade foram de 28,24 e $36,36 \%$, respectivamente, sendo inferiores as variações com microaspersores novos, porém elevadas comparando-se com valores apresentados por Keller e Karmeli (1974), que recomendam uma variação máxima de pressão de $20 \%$ e de vazão de $10 \%$ na subunidade.

Tabela 1. Valores das variáveis avaliadas na subunidade de irrigação em condições reais de campo, para microaspersores novos e usados.

\begin{tabular}{lrr}
\hline \multirow{2}{*}{ Variáveis } & \multicolumn{2}{c}{ Emissores } \\
\cline { 2 - 3 } & Usados & Novos \\
\hline Vazão Média $\left(\mathrm{L} \mathrm{h}^{-1}\right)$ & 32,9 & 36,9 \\
Vazão Máxima $\left(\mathrm{L} \mathrm{h}^{-1}\right)$ & 40 & 47 \\
Vazão Mínima $\left(\mathrm{L} \mathrm{h}^{-1}\right)$ & 25 & 26 \\
Vazão 25\% Mínima $\left(\mathrm{L} \mathrm{h}^{-1}\right)$ & 27,9 & 35,6 \\
Desvio Padrão de vazão $\left(\mathrm{L} \mathrm{h}^{-1}\right)$ & 3,7 & 4,44 \\
Variação de Vazão (\%) & 36,36 & 43,59 \\
Pressão Média (kPa) & 112 & 122 \\
Pressão Máxima (kPa) & 131 & 148 \\
Pressão Mínima (kPa) & 94 & 96 \\
Pressão 25\% Mínima (kPa) & 100 & 107 \\
Desvio Padrão de Pressão (kPa) & 9,8 & 12,4 \\
Variação de Pressão (\%) & 28,24 & 35,14 \\
Expoente de Descarga do Emissor - x & 0,87 & 0,64 \\
Coefic. de Unifor. de Irrigação (\%) - CU & 84,69 & 96,5 \\
Coefic. de Unifor. de Pressão (\%) - CUP & 89,59 & 87,8 \\
Fator de Correção das Vazões - FCV & 1,05 & 1,07 \\
Coefic. de Unifor. do Sistema (\%) - CUS & 89,25 & 100 \\
Eficiência de Aplicação (\%) - EA & 76,22 & 86,86 \\
Coefic. de Variação Total de Vazão (\%) - CVT & 0,11 & 0,12 \\
Coefic. de Unifor. Estatístico. (\%) - CUE & 88,82 & 88,0 \\
Coefic. de Variação da Vazão (\%) - CVH & 0,09 & 0,10 \\
Coefic. de Variação Estat. da Vazão (\%) - CVE & 0,01 & 0,01 \\
\hline
\end{tabular}

O coeficiente de variação da vazão $(\mathrm{CVH})$ e o coeficiente de variação total de vazão (CVT), respectivamente, de 0,10 e 0,12 foram altos, no entanto, sem diferença em relação aos valores com os microaspersores usados, próximo do encontrado por Zanini et al. (1998) que avaliando um sistema de irrigação por microaspersão, encontraram coeficientes de variação de vazão total variando de 0,85 a 0,11 . O coeficiente de variação estatístico da vazão (CVE) de 0,01 , que indica a variação da vazão devido a causas hidráulicas, não variou entre as duas avaliações realizadas, e foi considerado baixo, caracterizando como bom o coeficiente de 
variação de fabricação dos emissores analisados, indicando que parte da variação da vazão foi devido a diferentes causas como: obstrução do emissor, tempo de uso e da sustentabilidade de variação da vazão com o tempo; no entanto, pode-se dizer que, na subunidade avaliada com microaspersores novos, a variação de vazão foi devida, principalmente à variação de pressão.

O coeficiente de uniformidade de irrigação (CU) de 84,69\%, classificado como bom, foi para $96,5 \%$ com a troca dos microaspersores passando assim para excelente; para o coeficiente de uniformidade estatístico (CUE) não houve diferença considerável com a troca, o qual baixou de 88,82 para $88,0 \%$, permanecendo como bom, de acordo com a ASAE (1996).

O coeficiente de variação de pressão $\left(\mathrm{CU}_{\mathrm{P}}\right)$ de $87,8 \%$ baixou em relação à avaliação com os microaspersores usados, mas ainda não chegando a um valor satisfatório, de acordo com Keller e Bliesner (1990), que recomendam valores mínimos em torno de $80 \%$ como valor satisfatório. A eficiência de aplicação (EA) teve um aumento considerável de 10,64\% com a troca dos microaspersores, constatando-se que houve um ganho de eficiência na aplicação de água com os microaspersores novos, possivelmente devido às mudanças da área de passagem de fluxo, causando uma melhor uniformidade.

O expoente de descarga (x) dos emissores usados de 0,87 baixou para 0,64 com a troca por novos, verificando-se, então, que houve perda de qualidade com o tempo de uso, causando mais variação de vazão do que de pressão.

Os dados dos principais parâmetros estatísticos da vazão e da pressão da subunidade são apresentados na Tabela 2. Os resultados mostram valores máximo e mínimo de vazão de 40 e $25 \mathrm{~L} \mathrm{~h}^{-1}$ dos 28 microaspersores com três anos de uso, avaliados em condições reais de uso, com coeficiente de variação de $11,39 \%$. A vazão média foi de $32,93 \mathrm{~L} \mathrm{~h}^{-1}$, sendo menor que a média do valor obtido em laboratório de $39,39 \mathrm{~L} \mathrm{~h}^{-1}$ com o microaspersor submetido a uma pressão de $150 \mathrm{kPa}$. Quando se trocou os microaspersores usados por novos, o valor de vazão máxima foi de 46,80 $\mathrm{L} \mathrm{h}^{-1}$, havendo um aumento de $3,93 \mathrm{~L} \mathrm{~h}^{-1}$ na vazão média e um coeficiente de variação de $12,05 \%$.

Tabela 2. Valores dos parâmetros estatísticos e teste de KomolgorovSminov (KS), para a vazão e pressão de microaspersores usados e novos na subunidade de irrigação.

\begin{tabular}{lcccc}
\hline \multirow{2}{*}{ Parâmetros } & \multicolumn{2}{c}{ Vazão $\left(\mathbf{L ~ h ~}^{\mathbf{- 1}}\right)$} & \multicolumn{2}{c}{ Pressão (kPa) } \\
\cline { 2 - 5 } & Usado & Novo & Usado & Novo \\
\hline Média & 32,93 & 36,86 & 112 & 122 \\
Mediana & 34,00 & 36,00 & 115 & 122 \\
Desvio Padrão & 3,7 & 4,44 & 10 & 12 \\
Coeficiente de & 11,39 & 12,05 & 8,76 & 10,14 \\
Variação & 14,07 & 19,72 & 95,84 & 154,02 \\
Variância & 25,00 & 26,40 & 94 & 96 \\
Mínimo & 40,00 & 46,80 & 131 & 148 \\
Máximo & $0,257^{* *}$ & $0,218^{* *}$ & $0,133^{* *}$ & $0,159^{* *}$ \\
\hline Teste KS & & \multicolumn{3}{c}{}
\end{tabular}

** significativo a $1 \%$ de probabilidade.

Para os valores de pressão na subunidade, foi constatado que, para os microaspersores usados, a máxima pressão medida foi de $131 \mathrm{kPa}$, com um valor médio de $112 \mathrm{kPa}$; realizada a troca pelos microaspersores novos, a pressão teve um aumento médio de $10 \mathrm{kPa}$. 
A uniformidade da irrigação de um sistema de irrigação localizada pode ser melhorada se a redistribuição de água no solo for considerada. Para tanto é necessário descrever a distribuição espacial do armazenamento de água no solo, uma vez que mesmo em um solo considerado homogêneo, a variabilidade das propriedades físico-hídricas pode ser grande. Hamlett et al. (1986) afirmam que análises espaciais de dados têm sido cada vez mais empregadas, sendo baseadas na geoestatística, a qual considera as características estruturais e aleatórias de uma variável espacialmente distribuída.

São apresentados na Tabela 3 os valores dos parâmetros dos semivariogramas analisados de vazão e pressão da subunidade com microaspersores novos e usados, em que se pode verificar que o modelo matemático que melhor se ajustou à vazão dos microaspersores novos e usados, foi, respectivamente, o exponencial e esférico; para a pressão o modelo foi o inverso da vazão, ou seja, esférico para os novos e exponencial para os usados. Observa-se que quando o modelo foi esférico, ocorreram as menores variações não explicadas (efeito pepita) na vazão e na pressão; também é possível verificar que o alcance aumentou com o modelo esférico para a vazão e pressão. Pelos valores do patamar se constata que com a troca dos microaspersores os valores de vazão teriam de aumentar para se conseguir uma estabilidade.

Tabela 3. Estimativa dos parâmetros dos modelos ajustados aos semivariogramas para os valores de vazão e pressão na subunidade com microaspersores novos e usados.

\begin{tabular}{|c|c|c|c|c|c|c|}
\hline \multicolumn{2}{|c|}{ Parâmetros } & \multirow{2}{*}{$\begin{array}{r}\text { Efeito } \\
\text { Pepita } \\
\text { Co }\end{array}$} & \multirow{2}{*}{$\begin{array}{r}\text { Patamar } \\
\mathrm{Co}+\mathrm{Cl}\end{array}$} & \multirow{2}{*}{$\begin{array}{r}\begin{array}{c}\text { Alcance } \\
\text { (m) }\end{array} \\
\text { Ao }\end{array}$} & \multirow{2}{*}{$\begin{array}{c}\begin{array}{c}\text { Dependência } \\
\text { Espacial (\%) }\end{array} \\
(\mathrm{Co} /(\mathrm{Co}+\mathrm{Cl})) \\
100\end{array}$} & \multirow{2}{*}{$\begin{array}{l}\text { Aleatoriedade } \\
E=(\mathrm{Co} / \mathrm{Cl})\end{array}$} \\
\hline Variáveis & Modelo & & & & & \\
\hline $\begin{array}{l}\text { Vazão - } \\
\text { Novo }\end{array}$ & Exponencial & 5 & 35 & 212 & $14,2 \mathrm{ft}$ & $0,16 \mathrm{~s}$ \\
\hline $\begin{array}{l}\text { Vazão - } \\
\text { Usado }\end{array}$ & Esférico & 1 & 33 & 218 & $3,0 \mathrm{ft}$ & $0,031 \mathrm{~s}$ \\
\hline $\begin{array}{l}\text { Pressão - } \\
\text { Novo }\end{array}$ & Esférico & 12 & 334 & 225 & $3,6 \mathrm{ft}$ & $0,54 \mathrm{~ms}$ \\
\hline $\begin{array}{l}\text { Pressão - } \\
\text { Usado }\end{array}$ & Exponencial & 43 & 137 & 58 & $31,38 \mathrm{ft}$ & $0,45 \mathrm{~ms}$ \\
\hline
\end{tabular}

$\mathrm{ft}$ - forte; $\mathrm{s}$ - significativo; $\mathrm{ms}$ - muito significativo.

A Figura 2 apresenta o semivariograma da vazão e da pressão dos microaspersores usados e novos. Para o semivariograma da vazão com microaspersores usados (Figura 2A), o modelo foi esférico com uma variância de vazão em função da distância dos emissores, há três anos no campo, que apresenta efeito pepita de $1 \mathrm{~L} \mathrm{~h}^{-1}$, valor menor se comparado com os novos (Figura 2B), patamar de $33 \mathrm{~L} \mathrm{~h}^{-1}$, alcance de $218 \mathrm{~m}$, com uma dependência espacial menor de 3\%, classificada como forte de acordo com a classificação de Cambardella et al. (1994), e um grau de aleatoriedade significativo de 0,031. Para o semivariograma da vazão para os emissores novos (Figura 2B), o modelo foi exponencial, exibindo um efeito pepita de $5 \mathrm{~L} \mathrm{~h}^{-1}$, um patamar de $35 \mathrm{~L} \mathrm{~h}^{-1}$ e um alcance em que existe uma influência de uma amostra sobre a outra de $212 \mathrm{~m}$. A dependência espacial entre os emissores novos foi de $14,28 \%$ considerada como forte, de acordo com a classificação de Cambardella et al. (1994), sendo essa forte dependência justificada por se tratar de um sistema que está interligado; no entanto, 
os valores de vazão dependem do estado do emissor como mostra a aleatoriedade muito significativa de 0,16 entre esses valores.

A.

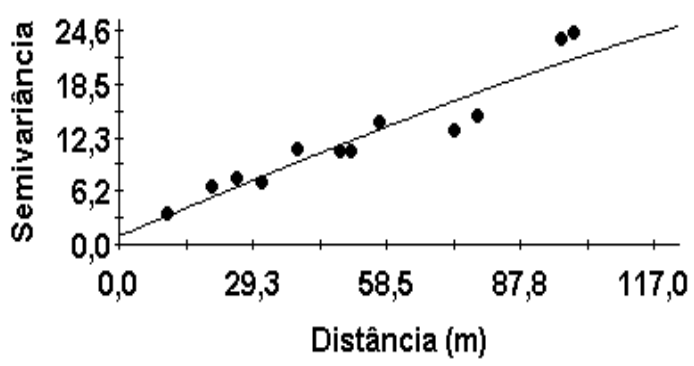

C.

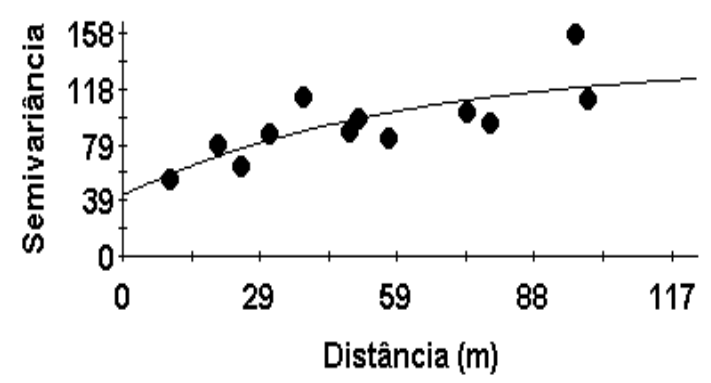

B.

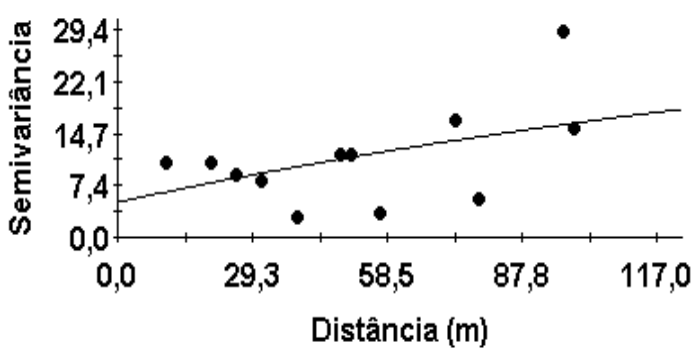

D.

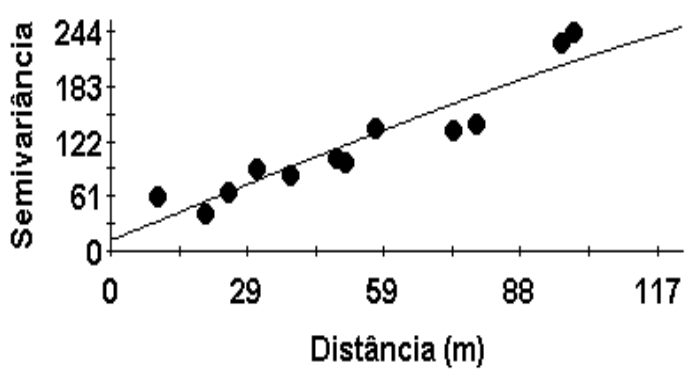

Figu999ra 2. Semivariogramas de vazão, para microaspersores usados (A) e novos (B), e de pressão, para microaspersores usados $(\mathrm{C})$ e novos (D), na subunidade de irrigação, mostrando o modelo ajustado aos dados em função da distância.

No semivariograma da pressão para os microaspersores usados (Figura 2C), o modelo foi exponencial, com um efeito pepita também baixo de $43 \mathrm{kPa}$, e o patamar de $137 \mathrm{kPa}$, expressando que a estabilidade seria atingida com essa pressão, sendo esperado esse resultado, pois com os emissores novos a pressão do sistema aumentou. $\mathrm{O}$ alcance foi de 58 $\mathrm{m}$, mostrando uma dependência espacial forte de 31,38\% e um grau de aleatoriedade muito significativo de 0,45 . O semivariograma da pressão com os microaspersores novos (Figura 2D), apresenta um modelo esférico, com um efeito pepita muito baixo de $12 \mathrm{kPa}$, patamar igual a $334 \mathrm{kPa}$ e um alcance de $225 \mathrm{~m}$, observando-se uma dependência espacial de 3,6\%, classificada novamente como forte, e um grau de aleatoriedade de 0,037 classificado como pouco significativo.

A Figura 3 exibe os mapas de isolinhas da vazão e da pressão, sendo a coordenada $\mathrm{x}$ a direção da linha de derivação e a coordenada y a direção das laterais. Observa-se que para os microaspersores usados (Figura 3A) não ocorreu muita variação na vazão, com uma média de $32,93 \mathrm{~L} \mathrm{~h}^{-1}$, ocorrendo no início da área, vazões maiores nos pontos de emissão e valores mínimos de $25 \mathrm{~L} \mathrm{~h}^{-1}$ no final. Já com os microaspersores trocados por novos (Figura 3B), a média aumentou para $36,86 \mathrm{~L} \mathrm{~h}^{-1}$, chegando a $46 \mathrm{~L} \mathrm{~h}^{-1}$ no início em que a vazão foi maior, diminuindo em direção ao final da tubulação secundária, com um valor mínimo de $26,40 \mathrm{~L} \mathrm{~h}^{-}$ 1. Observa-se que entre as causas dessa diminuição de vazão, uma delas foi a pressão do 
sistema, que quando comparado com os mesmos microaspersores testados em laboratório a uma pressão de $150 \mathrm{kPa}$, em que o coeficiente de variação de fabricação foi de apenas $0,01 \%$, a vazão média foi de $39,39 \mathrm{~L} \mathrm{~h}^{-1}$.

A.

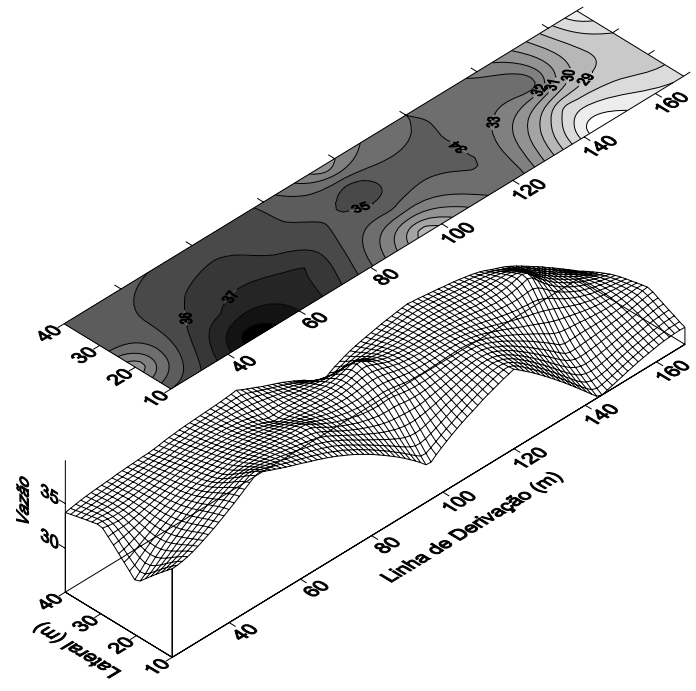

C.
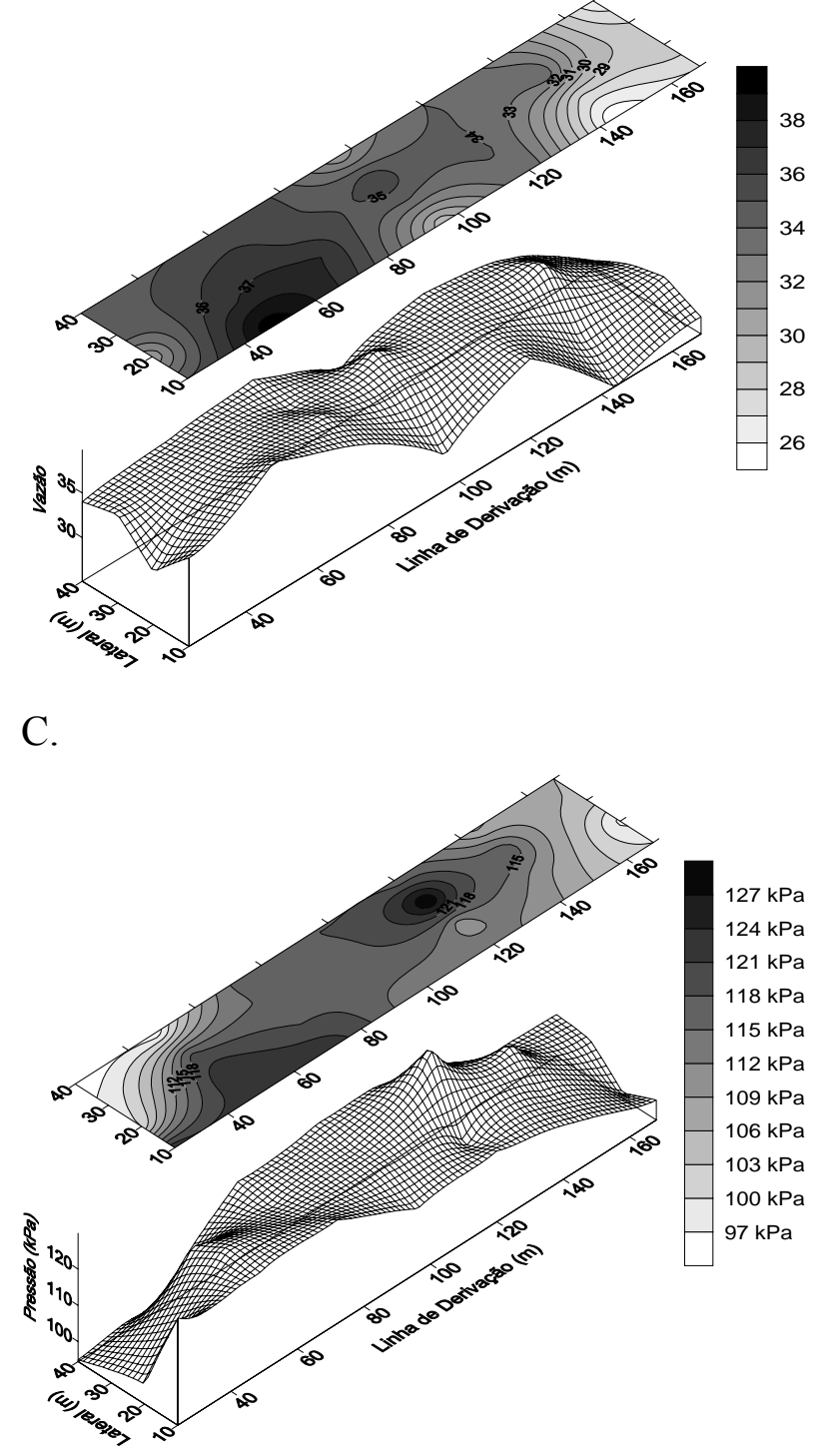

B.

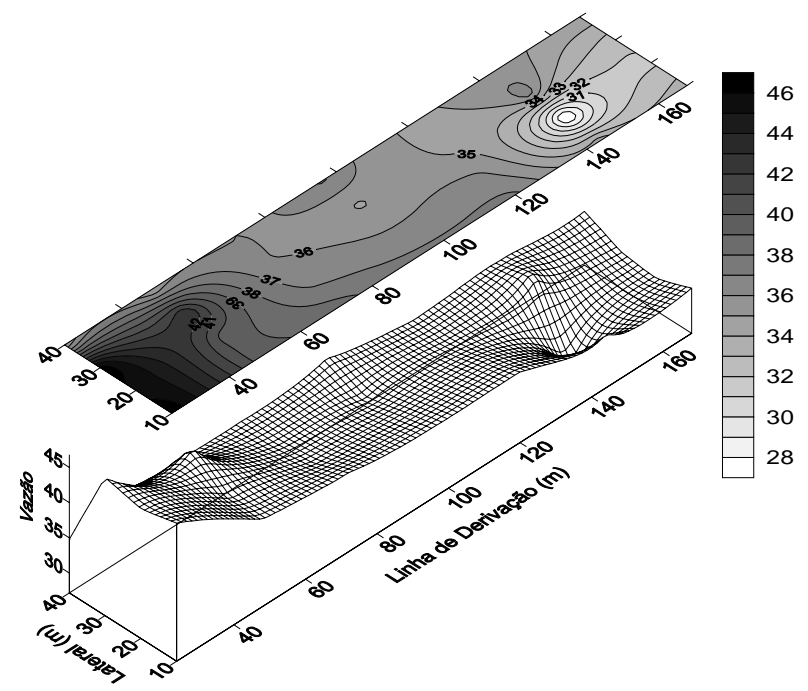

D.

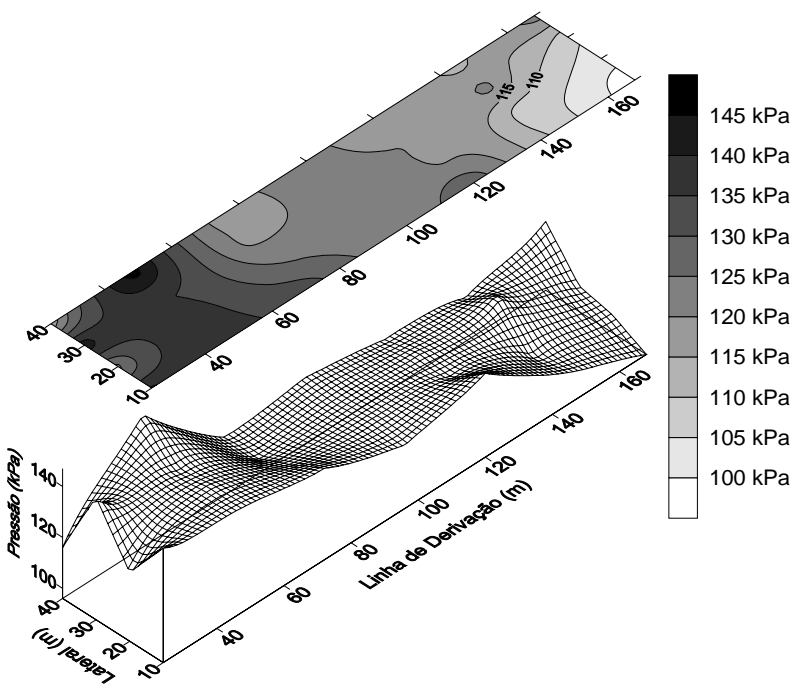

Figura 3. Mapas de isolinhas da vazão, para microaspersores novos (A) e usados (B) e da pressão, para microaspersores usados (C) e novos (D) na subunidade de irrigação.

O mapa de isolinhas da pressão para microaspersores usados (Figura 3C), gerado a partir de um modelo exponencial, apresenta valores mínimo e máximo de 94 e $131 \mathrm{kPa}$, respectivamente, em que é possível observar que os maiores valores estão no início da malha instalada na subunidade. Com as medidas de pressão nos pontos de emissão, tendo os microaspersores sido trocados por novos, pode-se observar pelo mapa de isolinhas (Figura 3D), que a média de $122 \mathrm{kPa}$ foi maior que na avaliação anterior, ou seja, para os microaspersores usados, mas apresentando uma variação de pressão maior de $52 \mathrm{kPa}$ entre os valores máximo e mínimo. 


\section{CONCLUSÕES}

Quando se trocaram em campo os emissores usados por novos, o coeficiente de uniformidade de irrigação, o coeficiente de uniformidade do sistema e a eficiência de aplicação d'água aumentaram em 11,9, 10,58 e 10,75\%, respectivamente.

A distância máxima (alcance) onde os dados estimados de vazão e pressão se correlacionam espacialmente extrapolou o comprimento da linha de derivação para a vazão com microaspersores novos e usados e para a pressão só com microaspersores novos.

O efeito pepita para pressão no sistema foi menor quando se trocaram os microaspersores usados por novos, ocorrendo o inverso para a vazão.

Houve um aumento tanto da pressão como da vazão quando se trocaram os microaspersores usados por novos.

\section{AGRADECIMENTOS}

Os autores agradecem ao Conselho Nacional de Desenvolvimento Científico e Tecnológico, CNPq, pelo suporte financeiro, fundamental ao desenvolvimento desta pesquisa.

\section{REFERÊNCIAS}

ANDRADE A. R. S. de; Aplicação da teoria fractal e da geoestatística na estimativa da condutividade hidráulica saturada e do espaçamento entre drenos em solos de vázea.. 2002. 181f. Tese (Doutorado em Irrigação e Drenagem) - UNESP, Botucatu, 2002.

ABREU, J. M. H.; LOPEZ, J. R.; REGALADO, A. P.; HERNANDEZ, J. F. G. El riego localizado. Madrid: Instituto Nacional de Investigaciones Agrarias, 1987. 317p.

AMERICAN SOCIETY OF AGRICULTURAL ENGINEERS - ASAE. Field evaluation of micro irrigation systems. EP458. St. Joseph: ASAE, 1996. p.792-797.

BARRETO FILHO, A. A.; DANTAS NETO, J.; MATOS, J. A.; GOMES, E. M. Desempenho de um sistema de irrigação por microaspersão, instalado em campo, Revista Brasileira de Engenharia agrícola e ambiental, Campina Grande, v. 4, n. 3, p. 309-314, 2000.

BOMAN, B. J. Distribution patterns of micro irrigations spinner and spray emitters. Applied Engineering Agriculture, St. Joseph, v. 5, n. 2, p. 50-60, 1989.

BRALTS, V. F.; KESNER, C. Drip irrigation field uniformity estimation. Transactions of the ASAE, St. Joseph, v. 24, n. 5, p. 1369-1374, 1983.

CAMBARDELLA, C. A.; MOORMAN, T. B.; NOVACK, J. M.; PARKIN, T. B.; KARLEN, D. L.; TURCO R. F.; KNOPKA, A. E. Field-scale variability of soil proprieties in central Iowa soil. Soil Science, v. 58, p. 1240-1248, 1994.

G+: Geostatistics for Environmental Science. Version 5.0. Michigan: Gamma Design Software, 2000.

GOLDEN SOFTWARE: surfer for Windows. Surface mapping system. New York, Version 7, 2001. 
HAMLETT, J. M.; HORTON, R.; CRESSIE, N. A. C. Resistant and exploratory techniques for use in semivariogram analyses. Soil Science Society of America Journal, v. 50 p. 868-875, 1986.

KELLER, J.; BLIESNER, R. D. Sprinkler and trickle irrigation. New York: Van Nostrand Reinhold, 1990. 652p.

KELLER, J.; KARMELI, D. Trickle irrigation design parameters. Transactions of the ASAE, St. Joseph, v. 17, n. 4, p. 678-684, 1974.

MERRIAN, J. L.; KELLER, J. Farm irrigation system evaluation: a guide for management. Logan: Utah State University, Agricultural and Irrigation Engineering Department, 1978. 271p.

QUEIROZ, J. E.; GONÇALVES, A. C.; SOUTO, J. S.; FOLEGATTI, M. V. Avaliação e monitoramento da salinidade do solo. In: GHEIY, H. R.; QUEIROZ, J. E.; MEDEIROS, J. F. Manejo e controle da salinidade na agricultura irrigada. Campina Grande: UFPB/SBEA, p. 69-111, 1997. Cap. 3.

ZANINI, J. R.; PAVANI, L. C.; TAROZZO, M. Avaliação da vazão de um sistema de irrigação por microaspersão em cultura de bananeira. In: CONGRESSO BRASILEIRO DE ENGENHARIA AGRÍCOLA, 27, 1998, Poços de Caldas. Resumos... Poços de Caldas: SBEA, 1998, v. 2, p.290-292. 


ISSN = 1980-993X-doi:10.4136/1980-993X
www.agro.unitau.br/ambi-agua
E-mail: ambi-agua@agro.unitau.br
Tel.: (12) 3625-4116

\title{
Disposição no solo de efluentes de esgoto tratado visando à redução de coliformes termotolerantes \\ (doi:10.4136/ambi-agua.63)
}

\author{
Teresa Blandina Castro Ribas ${ }^{1}$; Paulo Fortes Neto ${ }^{2}$ \\ ${ }^{1}$ Bióloga, M. Sc. em Ciências Ambientais da Universidade de Taubaté, SP \\ E-mail: teresaribas.castro@gmail.com \\ ${ }^{2}$ Eng. Agrônomo, Dr. Professor do Curso de Pós-Graduação em Ciências Ambientais da Universidade de \\ Taubaté, SP \\ E-mail: paulofortes.neto@gmail.com
}

\section{RESUMO}

O lançamento indiscriminado nos corpos d’água de esgotos domésticos sem tratamento, ou mesmo tratados, mas sem desinfecção apropriada, contribui com quantidade significativa de organismos do chamado "grupo coliforme", entre os quais agentes específicos de doenças de veiculação hídrica podem estar presentes. A aplicação no solo de efluentes de esgotos domésticos devidamente tratados, em vez de sua disposição direta em cursos d'água, além de ser uma maneira alternativa para disposição de resíduos e controle biológico de poluentes, constitui um modo adequado de fornecimento de nutrientes ao solo e às plantas. Este trabalho teve como objetivo avaliar a redução de coliformes termotolerantes após aplicações no solo de efluente de esgoto doméstico tratado por um período de 60 dias, associando os valores obtidos ao adensamento de rizobactérias Pseudomonas fluorescens e Bacillus spp. presentes nas rizosferas de diferentes culturas. O experimento foi desenvolvido em área da Fazenda Piloto do Departamento de Ciências Agrárias da Universidade de Taubaté e o Delineamento Experimental constou de blocos casualizados com cinco tratamentos envolvendo o cultivo de aveia, cevada, triticale, feijão preto e solo sem cultivo (Testemunha), totalizando 20 parcelas de solo classificado como Latossolo Vermelho Amarelo Distrófico. Os resultados obtidos por meio de análises microbiológicas de amostras de solo rizosférico e não rizosférico apresentaram um maior adensamento de rizobactérias na rizosfera da aveia. Entretanto, a maior eficiência obtida na redução de coliformes termotolerantes foi alcançada nos tratamentos envolvendo feijão preto e solo sem cultivo.

Palavras-chave: disposição no solo; fitorremediação; esgoto; coliformes; Pseudomonas; Bacillus.

\section{Controlled disposal of domestic effluent sewage in the ground to reduce fecal coliforms}

\begin{abstract}
The indiscriminate launching in water bodies of domestic sewage without treatment, or even treated, but without appropriate disinfection, contributes with significant amount of organisms of the called "coliform group" that can carry specific illnesses agents propagated through the water. The application of effluent in the ground, instead of direct disposal in water courses, in addition to being an alternative way for the disposal of residues and biological control of pollutants, constitutes an adequate way of nutrients supply to the soil and
\end{abstract}


plants. So, this work had as objective the evaluation of the reduction of fecal coliforms, after controlled applications of 60 days treated effluent in cultivated soil, by analyzing the increase of fluorescent rhizobacterias Pseudomonas fluorescens and Bacillus spp. present in the rhizospheres of different crops. The experiment was developed in field conditions in the Experimental Farm of Department of Agrarian Sciences of the University of Taubaté, municipality of Taubaté, SP. The Experimental design consisted of random blocks, with five treatments including annual crops (Oats, Barley, Triticale - a cross between wheat and rye, Black Beans and non-cultivated soil as witness - blank reference) and four repetitions, totalizing 20 ground plots with area of $2 \mathrm{~m} \mathrm{x} 1 \mathrm{~m}$ with $50 \mathrm{~cm}$ space among plots on a Dystrophic Red-Yellow Latossol. Results from the microbial analyses of rhizosphere and non-rhizosphere soil indicated that the rhizosphere of oats had denser rhizobacterias than the other crops. However, the greatest efficiency was found in the reduction of thermo-tolerant coliforms for both black beans and non-cultivated soil.

Keywords: application in the ground; sewage; wastewater; coliforms; rhizobacterias.

\section{INTRODUÇÃO}

O efluente doméstico, por ser um resíduo altamente poluidor, tem nos últimos anos demandado pesquisas com ênfase no desenvolvimento de tecnologias adequadas e de baixo custo para o tratamento e disposição de águas residuárias.

O lançamento indiscriminado nos corpos d'água de esgotos domésticos sem tratamento, ou mesmo tratados, mas sem desinfecção apropriada, contribui com quantidade significativa de organismos do chamado "grupo coliforme", entre os quais agentes específicos de doenças de veiculação hídrica podem estar presentes.

A aplicação do efluente no solo, em vez de sua disposição direta em cursos d'água, além de ser uma maneira alternativa para disposição de resíduos e controle biológico de poluentes, constitui um modo adequado de fornecimento de nutrientes ao solo (Fonseca, 2000).

Ao entender o solo como um elemento depurador e o sistema solo-planta como um reator renovável, reator este regido pelas leis da natureza, pode-se entender também, nesse contexto, os esgotos como fonte de energia, e não como um grande problema ambiental.

O solo é o habitat natural para uma grande variedade de organismos, tanto microrganismos, quanto animais invertebrados. Esse conjunto que vive e é responsável por inúmeras funções do solo é chamado de microbiota do solo e apresenta uma grande variedade de tamanhos e metabolismos.

Os microrganismos são extremamente diversos com várias centenas de espécies de fungos e uma grande diversidade de tipos de bactérias com populações que variam de $10^{6}$ a $10^{9}$ células por centímetro cúbico (Swift et al., 1979).

Uma das tecnologias para tratamento de efluentes sanitários empregada, embora não seja nova, mas que tomou impulso nos últimos dez anos, é a Fitorremediação, uma vez que a zona radicular das plantas, chamada de rizosfera, apresenta uma capacidade de transformar moléculas orgânicas exógenas em fontes de nutrientes para os diversos microrganismos que habitam nessa região (Dinardi et al., 2007). Trata-se de uma estratégia in situ que envolve o emprego de espécies vegetais adequadas e microrganismos a elas associados com o fim de degradar, reter e remover poluentes orgânicos e inorgânicos do solo e água.

A colonização da rizosfera - área ao redor das raízes - deve-se a uma maior disponibilidade de nutrientes em relação ao solo não-rizosférico.

Bactérias do grupo fluorescente do gênero Pseudomonas e gênero Bacillus spp. caracterizam-se por serem os dois mais abundantes gêneros de microrganismos presentes nos 
solos, sendo considerados importantes agentes de controle biológico, pois podem suprimir patógenos da rizosfera, por meio de mecanismos de inibição que incluem predação, competição por espaço e nutrientes, produção de antibióticos, ácido cianídrico e sideróforos, que são compostos de baixo peso molecular, quelantes de ferro, produzidos pela maioria das bactérias sob condições limitantes desse elemento. Podem ainda atuar como biorremediadores de áreas contaminadas, por degradarem substâncias xenobióticas.

$\mathrm{Na}$ variedade de microrganismos conhecidos que sintetizam sideróforos além das bactérias já mencionadas do gênero Pseudomonas e Bascillus spp., estão incluídas, também, várias bactérias entéricas; bactérias patogênicas de humanos do sub-grupo coliformes termotolerantes, dentre elas Escherichia coli, Salmonella typhimurim e Aerobacter aerogenes (Benite e Machado, 2002).

Sendo assim, dada a relevância e atualidade da problemática da contaminação dos recursos naturais pela prática de descarte de efluentes domésticos no solo, o objetivo deste trabalho foi verificar se a disposição no solo de efluentes de esgoto doméstico tratado favorece o adensamento de rizobactérias do gênero Pseudomonas do grupo fluorescente e do gênero Bacillus spp., associando os valores obtidos com a redução de coliformes termotolerantes presentes no efluente tratado.

\section{MATERIAL E MÉTODOS}

\subsection{Localização e instalação do experimento}

O experimento foi conduzido em condições de campo na Fazenda-Piloto do Departamento de Ciências Agrárias da Universidade de Taubaté, Município de Taubaté, Estado de São Paulo. Localizado nas Coordenadas Geográficas 2302'34”S e 45³1'02”W, com altitude média de 577 m e distante 140 km da cidade de São Paulo.

O clima local de acordo com a Classificação de Köpen (1948) é do tipo Cwa (Subtropical), com chuvas de verão e com uma precipitação média anual de $1300 \mathrm{~mm}$.

O solo da área experimental é classificado como Latossolo Vermelho-Amarelo distrófico, de textura argilo-arenosa, constituído por perfil não hidromórfico, profundo, de fertilidade natural baixa, cuja característica química determinada na camada de 0-20 cm de profundidade está apresentada na Tabela 1:

Tabela 1. Característica Química Natural do solo da área experimental.

\begin{tabular}{|c|c|c|c|c|c|c|c|c|c|c|c|c|c|}
\hline $\mathrm{pH}$ & $\begin{array}{l}\text { MO } \\
\text { (a) } \\
\mathrm{g} / \mathrm{dm}^{3}\end{array}$ & $\begin{array}{c}\mathrm{P} \\
\mathrm{mg} / \mathrm{dm}^{3}\end{array}$ & K & Ca & $\mathrm{Mg}$ & $\mathrm{H}+\mathrm{Al}$ & $\begin{array}{l}\text { SB } \\
\text { (D) }\end{array}$ & $\begin{array}{l}\text { CTC } \\
\text { (c) }\end{array}$ & B & $\mathrm{Cu}$ & $\mathrm{Fe}$ & $\mathrm{Mn}$ & $\mathrm{Zn}$ \\
\hline 7,1 & 15 & 8 & 1,4 & 95 & 12 & 11 & 108,4 & 119,4 & 0,13 & 0,8 & 25 & 6,0 & 1,4 \\
\hline
\end{tabular}

Fonte: Laboratório de Análises de Solos e Plantas - Depto. de Ciências Agrárias da UNITAU.

(a) MO = Matéria Orgânica; (b) SB = Soma de bases; (c) CTC = Capacidade de troca catiônica.

O delineamento experimental foi composto por blocos casualizados, com cinco tratamentos e quatro repetições (Figura 1), perfazendo assim um total de 20 parcelas. As parcelas de 2 x $1 \mathrm{~m}$ foram construídas com $50 \mathrm{~cm}$ de distância entre si e os blocos separados com distância de $1 \mathrm{~m}$.

Os estudos foram iniciados em maio de 2007, com a demarcação das 20 parcelas e coletas de amostras de solo na camada de $0-20 \mathrm{~cm}$ em todas as parcelas para realização de análise de propriedades químicas antes da aplicação do efluente. A semeadura foi realizada em junho com o cultivo de quatro culturas. 
Das quatro culturas utilizadas no experimento, três espécies foram da família das Gramíneas, a aveia (Avena fafua) - Tratamento 1; a cevada (Hordum vulgar) - Tratamento 2 e o triticale (Triticosecale Wittmack) - Tratamento 4. A quarta espécie utilizada foi da família das Leguminosas, o feijão preto (Phaseolus vulgaris L.), Tratamento 3. Como Testemunha foi utilizado solo sem cultivo - Tratamento 5.

O espaçamento utilizado para cultivo das gramíneas dentro de cada parcela foi de $20 \mathrm{~cm}$ e para a leguminosa o espaçamento foi de $40 \mathrm{~cm}$. A irrigação das culturas com água encanada foi realizada duas vezes por semana, teve como objetivo favorecer a germinação das sementes e, posteriormente, manutenção das plantas. A aplicação do efluente de esgoto tratado, seguindo a técnica de irrigação superficial, foi realizada com periodicidade de 60 dias e com intervalos de vinte dias entre cada aplicação, totalizando três aplicações. A primeira aplicação ocorreu 30 dias após a semeadura.

O efluente de esgoto utilizado no experimento foi proveniente do sistema de tratamento por leito cultivado implantado no Departamento de Ciências Agrárias - UNITAU, o qual trata o esgoto dos sanitários, laboratórios e cozinha existentes no prédio central do Departamento. A composição do efluente é basicamente advinda da higiene humana, tendo pouca contribuição de produtos químicos das atividades laboratoriais. Apresentou $\mathrm{pH}$ de 7,2 e Demanda Química de Oxigênio (DQO) de 324 mg.L ${ }^{-1}$.

O Sistema de tratamento de esgoto por leito cultivado estruturalmente é composto por um tanque séptico (Tratamento primário), construído em concreto armado e com $30 \mathrm{~m}^{3}$ de capacidade, dois filtros anaeróbios compartimentados, instalados em duas caixas d'água de cimento amianto de $1 \mathrm{~m}^{3}$ cada e preenchidos com brita $\mathrm{n}^{\circ} 2$. Sendo o primeiro filtro de fluxo descendente seguido do segundo por fluxo ascendente (Tratamento secundário) e o leito cultivado (Tratamento secundário), construído em concreto armado, preenchido com brita $\mathrm{n}^{\circ}$ 2 e capacidade de $15 \mathrm{~m}^{3}$.

A espécie vegetal utilizada para compor o leito e cultivada diretamente sobre a brita foi a Zantedeschia aethiopica, conhecida popularmente como Copo-de-leite.

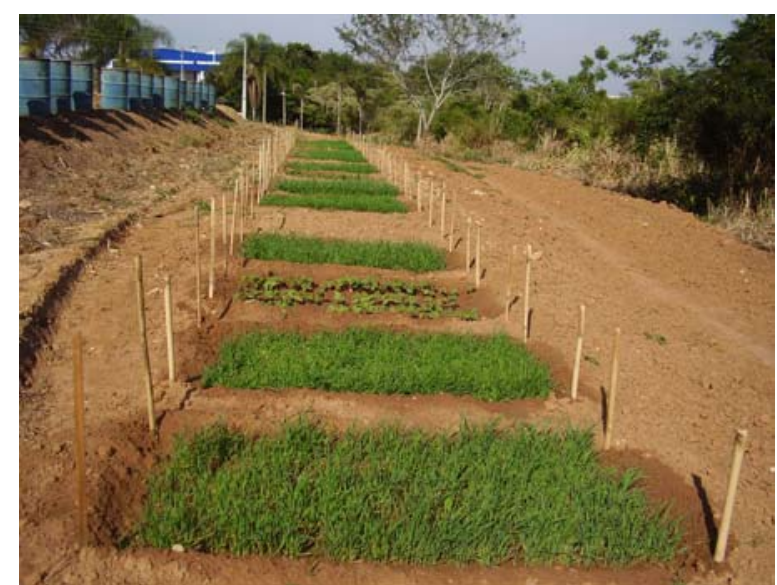

Figura 1. Vista do experimento, composto por cinco tratamentos com quatro repetições. Sendo quatro tratamentos com solo cultivado (aveia, cevada, triticale e feijão preto) e um tratamento sem cultivo (Testemunha).

O volume de efluente de esgoto tratado aplicado em cada tratamento foi de 170 litros por parcela de solo. Utilizou-se uma mangueira de $3 / 4$ " conectada a saída do leito cultivado para o enchimento de 20 tambores de 200 litros, posicionados a frente de cada uma das parcelas, dos tambores o efluente foi distribuído superficialmente por meio de mangueiras de $1 / 2$ ”. 


\subsection{Monitoramento/ Procedimentos para amostragens e Análises microbiológicas}

\subsubsection{Solo}

Para coletas de amostras de solos rizosféricos, foram retiradas de cada parcela cultivada 6 plantas com torrão de solo aderido às raízes, acondicionadas em sacos plásticos identificados e levadas ao Laboratório de Microbiologia Agrícola e Fitopatologia do Depto. de Ciências Agrárias da UNITAU.

As raízes de cada uma das 6 amostras por parcela foram agitadas vigorosamente para desprender o solo que estava aderido e homogeneizadas, formando uma amostra composta por parcela. Das parcelas não cultivadas, foram retiradas amostras de solo na camada de 0-20 $\mathrm{cm}$ e realizados os mesmos procedimentos descritos acima.

Foram pesadas $10 \mathrm{~g}$ de cada amostra composta e colocadas em frascos com capacidade de $90 \pm 2 \mathrm{~mL}$ com tampa de rosca, contendo solução salina esterilizada (solução tampão de Fosfato Monopotássico e Cloreto de Magnésio). A partir daí prepararam-se diluições em série de fator 10 da suspensão de solo obtida para análises de bactérias dos gêneros Pseudomonas spp., Bacillus spp. e Coliformes termotolerantes (Escherichia coli).

Para análise química do solo, foram pesadas novamente $10 \mathrm{~g}$ de cada amostra de solo, acondicionadas em sacos plásticos identificados e levadas ao Laboratório de Análises de Solo e Plantas do Depto de Ciências Agrárias da UNITAU para realização da avaliação das características químicas do solo após aplicação do efluente.

\subsubsection{Contagem de bactérias do grupo fluorescente do gênero Pseudomonas}

Alíquotas de $0,1 \mathrm{~mL}$ de cada diluição $10^{-2}, 10^{-3}$ e $10^{-4}$, foram transferidas para as placas de Petri contendo meio de cultura B de King (King et al., 1954) e espalhadas com alça de Drigalski em triplicata. As placas foram mantidas a $28^{\circ} \mathrm{C} \pm 2^{\circ} \mathrm{C}$ por 72 horas. Após o período de incubação as colônias foram observadas sob incidência de luz ultravioleta no interior da câmera negra, para avaliação da presença ou não de um halo esverdeado fluorescente, característico das Pseudomonas fluorescens. Na Figura 2, é mostrada uma placa de Petri contendo três colônias de bactérias do grupo fluorescente do gênero Pseudomonas com halos esverdeados fluorescentes.

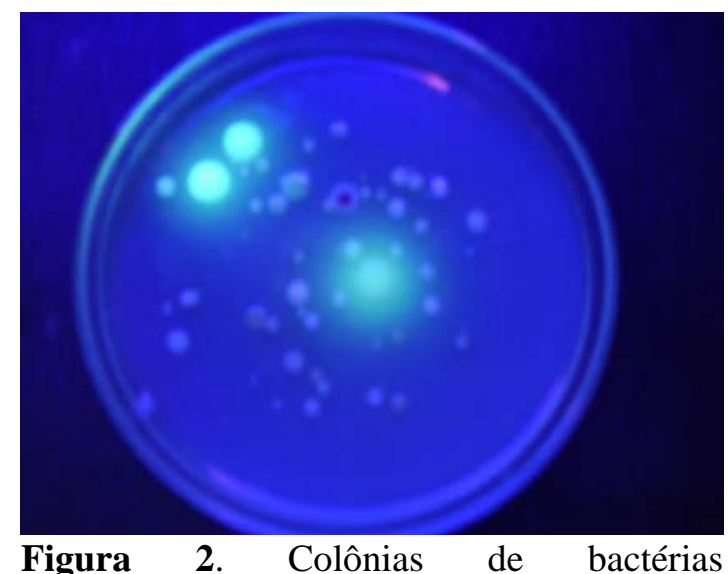

Figura 2. Colônias de bactérias Pseudomonas fluorescens observadas sob incidência de luz ultravioleta - Laboratório de Microbiologia Agrícola e Fitopatologia UNITAU. 


\subsubsection{Contagem de bactérias do gênero Bacillus}

O procedimento utilizado para contagem de Bacillus spp. foi semelhante ao descrito no item 2.2.1.1 para contagem de Pseudomonas, só que as diluições em série foram colocadas em banho maria a $\pm 80^{\circ} \mathrm{C}$ por 20 minutos e resfriadas a temperatura ambiente antes de serem transferidas para as placas de Petri.

Alíquotas de $0,1 \mathrm{~mL}$ das diluições $10^{-3}, 10^{-4}$ e $10^{-5}$, com três repetições, foram transferidas para placas de Petri contendo meio de cultura BDA (Batata Dextrose Agar). A contagem de colônias que cresceram em meio de cultura BDA foi feita após incubação a $\pm 28^{\circ} \mathrm{C}$ por 72 horas. Os resultados estão expressos em unidades formadoras de colônias por grama de solo seco (UFC/g solo seco).

\subsubsection{Contagem de Coliformes termotolerantes}

A metodologia empregada para a contagem do número mais provável (NMP) de Coliformes termotolerantes seguiu o preconizado no Standard Methods for the Examination of Water and Wastwater. (APHA, 2000), utilizando-se a Técnica de Tubos Múltiplos (TTM).

Para o Teste Presuntivo para contagem de bactérias do grupo coliformes, utilizou-se meio de cultura Caldo Lactosado e para o Teste Confirmativo para Coliformes termotolerantes, especificamente para Escherichia coli, o meio E.C..

Alíquotas de $1 \mathrm{~mL}$ dos frascos contendo amostras de solo dos 20 tratamentos diluídas em solução salina nas séries $10^{-1}, 10^{-2}, 10^{-3}, 10^{-4}, 10^{-5}$ e $10^{-6}$, foram inoculadas na série de 5 tubos para cada diluição contendo meio caldo lactosado. Foi efetuada a incubação à $35^{\circ} \mathrm{C} \pm 0,5^{\circ} \mathrm{C}$ durante 24/48 horas e ao final feita a $1^{\text {a }}$ leitura ainda do ensaio presuntivo.

Considera-se o resultado positivo à fermentação do meio evidenciada pela produção do gás. Com o uso de alça de platina, fez-se a inoculação do material dos tubos positivos para cada tubo correspondente do meio E.C. Após a transferência, os tubos contendo amostras positivas em meio E.C. foram transferidos para incubadora a $44,5^{\circ} \mathrm{C} \pm 0,5$ por um período adicional de $24 \pm 2$ horas.

A densidade de coliformes foi expressa em N.M.P. de coliformes termotolerantes por 100 mL de água, o qual é obtido por meio de tabela no Standard Methods (APHA, 2000).

\subsubsection{Efluente de esgoto tratado}

Para amostragem de efluente proveniente da ETE por leito cultivado, procedeu-se à coleta de $100 \mathrm{~mL}$ de água residuária em frasco com tampa esterilizado na saída do sistema. A amostra foi levada ao Laboratório de Microbiologia Agrícola e Fitopatologia para realização dos procedimentos para as análises microbiológicas para contagem de unidades formadoras de colônias de rizobactérias Pseudomonas fluorescens, Bacillus spp. e o número mais provável de coliformes termotolerantes.

A realização das análises microbiológicas do efluente de esgoto tratado seguiram os mesmos procedimentos e técnicas descritos nos itens acima para análises microbiológicas de solo.

\section{RESULTADOS E DISCUSSÃO}

A temperatura média e umidade relativa do ar registradas durante o período de desenvolvimento do experimento foram de $32^{\circ} \mathrm{C}$ e $28 \%$, respectivamente. Esses valores indicam a predominância de dias quentes e baixa umidade do ar durante o desenvolvimento do projeto. Não houve ocorrência de chuvas na época de coletas de amostras de solo para análises microbiológicas do solo nos 20 e 40 dias após o início das aplicações de efluente. 
Entretanto, na época de realização da coleta de amostras de solo, 60 dias após a primeira irrigação foram registradas chuvas de baixa intensidade.

Esses fatores físicos, como elevada temperatura ambiente, baixa umidade do ar e baixa precipitação pluviométrica podem ter interferido significativamente na sobrevivência de coliformes termotolerantes no solo, inviabilizando condições favoráveis ao seu crescimento. Já a ocorrência de chuvas aumentando a umidade do solo associada à matéria orgânica proveniente do efluente pode ter criado condições favoráveis à sobrevivência de coliformes termotolerantes, inclusive, possibilitando o aumento de sua concentração.

Os resultados da densidade de colônias de Pseudomonas fluorescens e Bacillus spp. em unidades formadoras de colônias por grama de solo seco (UFC.g ${ }^{-1}$ ) e do número mais provável de coliformes termotolerantes por grama de solo seco (NMP.g ${ }^{-1}$ ), obtidos em cada tratamento foram submetidos ao Teste de Duncan a 5\% de probabilidade e são apresentados a seguir nas Figuras 3, 4, 5, 6 e 7, e discutidos ao longo deste capítulo.

As análises microbiológicas do efluente de esgoto tratado realizadas antecedendo as amostragens de solo, respectivamente aos 20, 40 e 60 dias apresentaram valor médio de concentração de coliformes termotolerantes de 1 x $10^{6} \mathrm{NMP} / 100 \mathrm{~mL}$ de efluente.

A Figura 3 apresenta a concentração de coliformes termotolerantes verificada em cada um dos tratamentos, após a terceira aplicação de efluente, o que corresponde a 60 dias após a primeira aplicação e período de 120 dias do ciclo vegetativo das culturas.

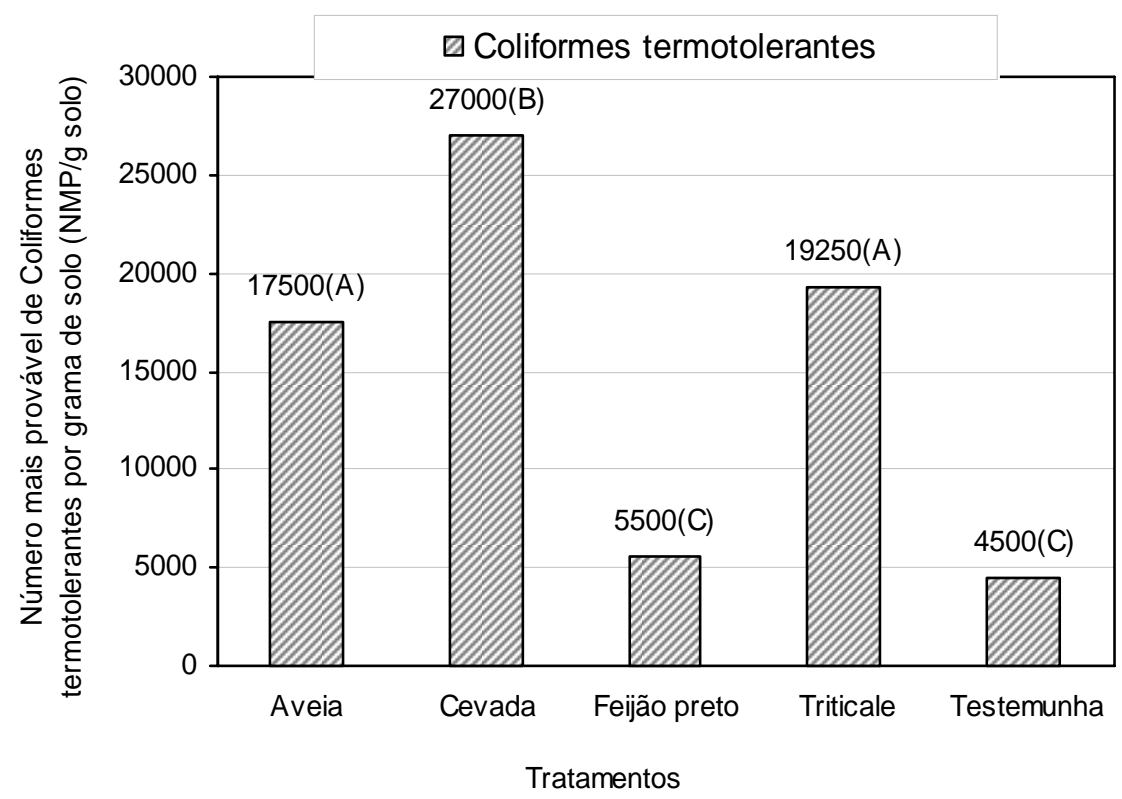

Figura 3. Valores Médios do Número Mais Provável de coliformes termotolerantes na camada de $0-20 \mathrm{~cm}$ de profundidade de solo cultivado com diferentes culturas e testemunha, tratado com aplicações de efluente de esgoto doméstico, 60 dias após a primeira aplicação. Médias seguidas de letras maiúsculas iguais, não diferem significativamente entre si pelo teste de Duncan a $5 \%$ de probabilidade.

Nas análises microbiológicas de amostras de solo realizadas 20 e 40 dias após a primeira aplicação de efluente não foi constatada a existência de coliformes termotolerantes no solo em todos os tratamentos, o que pode ser entendido como resultado da atuação das rizobactérias Pseudomonas fluorescens e Bacillus spp., entre outros microrganismos presentes não avaliados neste trabalho, por meio de mecanismos antagonistas, predação, competição, 
antibiose e produção de sideróforos, visto o teor de ferro presente no solo no local do experimento ser de $25 \mathrm{mg} / \mathrm{dm}^{3}$, considerado pelo Sistema IAC como baixo teor.

A reduzida concentração de matéria orgânica no solo variando de 15 a $19 \mathrm{mg} / \mathrm{dm}^{3}$, pode ser considerada como fator de competição por nutrientes entre a população de rizobactérias e coliformes. Assim, como investigado por Butler et al. (1954) ao aplicarem esgoto sanitário tratado na superfície de um solo argilo-arenoso e verificaram que, a partir de $3 \mathrm{~m}$ no perfil do solo, os coliformes fecais não conseguem sobreviver, provavelmente em razão da ausência do material orgânico, fundamental para a sua sobrevivência.

Entretanto, nas análises microbiológicas 60 dias após as três aplicações verificou-se que os tratamentos envolvendo a aveia e o triticale apresentaram valores de coliformes termotolerantes entre $17,5 \times 10^{3}$ e 19,0 x10³ NMP/100 ml de água residuária, o que resultou numa eficiência de $98,0 \%$ na redução de coliformes termotolerantes; a cevada apresentou valor de 27 x10 $\mathrm{NMP} / 100 \mathrm{~mL}$ de água, o que corresponde a uma eficiência na redução de coliformes termotolerantes de $97,0 \%$; e o feijão preto e testemunha apresentaram valores entre $6,0 \times 10^{3}$ e 9,0 x10 $\mathrm{NMP} / 100 \mathrm{~mL}$ registrando uma eficiência de 99,4\% na redução de coliformes termotolerantes. As diferenças de valores obtidos nos tratamentos aveia e triticale não foram significativos, já a cevada mostrou a menor eficiência e os melhores resultados na redução de coliformes termotolerantes foram obtidos nos tratamentos com feijão preto e solo sem cultivo.

Observa-se que os melhores resultados na redução de coliformes termotolerantes foram obtidos até 40 dias após as aplicações de efluente, coincidindo com o pleno desenvolvimento vegetativo das culturas utilizadas, ou seja, 90 dias, em que há a maior produção de exsudados pelas raízes das plantas e, conseqüentemente, maior adensamento de microrganismos nas rizosferas e no solo.

Esses resultados estão de acordo com estudos de Zavaleta-Mejia e Van Gundy (1982); Becker et al. (1988), os quais mostram que as bactérias são os organismos mais abundantes na rizosfera das plantas e podem apresentar efeito antagônico a vários patógenos.

Resultados similares foram obtidos por McGauher e Krone (1967) ao estudarem a remoção de coliformes fecais durante a percolação de água residuária por meio do perfil do solo, identificando confinamento das bactérias na camada de 0,0 a 0,9 m e a redução de $64 \%$ no nível populacional, após 12 dias.

Já a constatação de coliformes após 60 dias coincide com o término do ciclo, no qual o número de colônias de bactérias nas rizosferas se encontrava muito reduzido. Nesse período a maior eficiência na redução de coliformes foi alcançada nos tratamentos envolvendo feijão preto, o qual apresenta ciclo vegetativo de 90 dias em relação à aveia, à cevada e ao triticale que é de 120 dias e testemunha.

Em concordância com Chernicharo (1997), o qual menciona sobre a atuação de fatores físicos, tais como: umidade, $\mathrm{pH}$, radiação solar, temperatura e concentração de matéria orgânica influenciando no tempo de sobrevivência dos coliformes no ambiente, acredita-se que os resultados obtidos neste experimento estejam também relacionados a fatores físicos, como temperatura e umidade. Já que a arquitetura da planta do feijão confere menor sombreamento, assim como, o solo sem cobertura vegetal (testemunha) propiciam maior exposição solar, elevando a temperatura e reduzindo a umidade no solo, resultando em condições desfavoráveis à sobrevivência e ao desenvolvimento de coliformes termotolerantes.

O controle biológico de nematóides não é restrito apenas às interações entre esses fitopatógenos e seus antagonistas, mas ambos são influenciados pela planta, pelo ambiente físico e pelas microflora e microfauna do solo (Stirling, 1991).

Uma rizobactéria do grupo das fluorescentes, três Pseudomonas não fluorescentes e uma Bacillus spp. reduziram em até 53\% o número de galhas de $M$. incógnita em tomateiros, sendo as mais eficientes entre as 156 testadas por Habte e Byappanahalliu (1994). 
Rizobactérias do gênero Bacillus também estão freqüentemente associadas ao controle de nematóides, mas outros gêneros também se mostram promissores (Sikora, 1992).

A Figura 4 apresenta os valores médios obtidos em quatro repetições dos cinco tratamentos da quantidade de colônias de Pseudomonas fluorescens e Bacillus spp. presentes nas rizosferas das culturas e testemunha, antes da primeira irrigação.

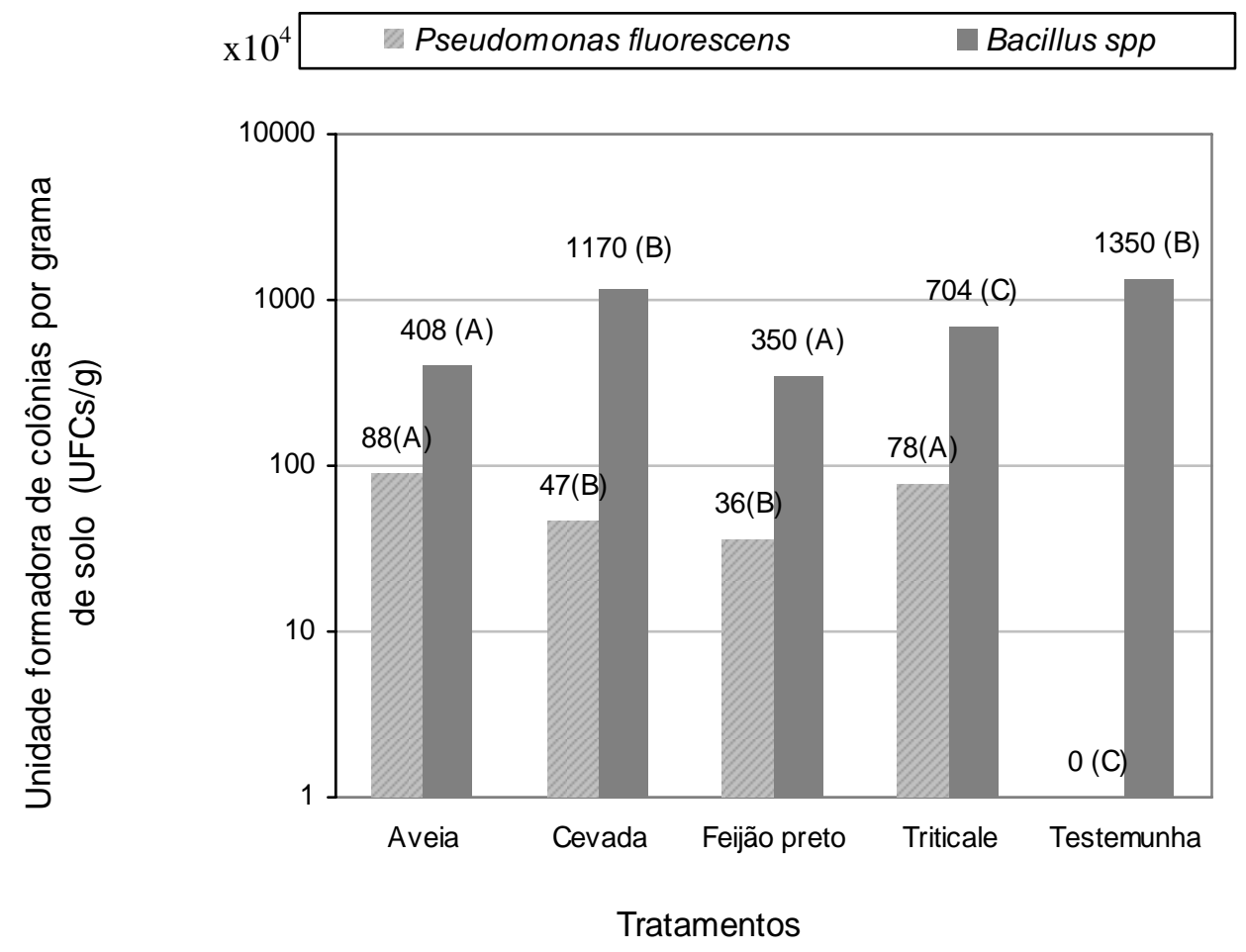

Figura 4. Valores médios de Unidades formadoras de colônias de Pseudomonas fluorescens e Bacillus spp. na camada de 0-20 cm de profundidade de solo cultivado com diferentes culturas e testemunha, antes da aplicação de efluente doméstico tratado. Médias seguidas de letras maiúsculas iguais não diferem significativamente entre si pelo teste de Duncan a 5\% de probabilidade.

Antecedendo a aplicação de efluente tratado no solo, verificou-se a inexistência de colônias de Pseudomonas fluorescens no tratamento testemunha. Contrariamente, a quantidade de Bacillus spp. presente foi a maior em relação aos demais tratamentos envolvendo solos cultivado.

Nos tratamentos com aveia e triticale, registraram-se os maiores valores entre $78 \times 10^{4} \mathrm{e}$ $88 \times 10^{4}$ unidades formadoras de colônias por grama de solo seco (UFCs. ${ }^{-1}$ ) de Pseudomonas fluorescens; nos tratamentos com cevada e feijão preto registraram-se quantidades menores entre $36 \times 10^{4}$ e $47 \times 10^{4}$ UFCs.g $^{-1}$. Esses resultados indicam que as rizosferas da aveia e triticale possibilitam uma maior colonização de rizobactérias Pseudomonas fluorescens, o que possivelmente esteja relacionado às substâncias exsudadas por suas raízes.

Em relação à quantidade de Bacillus spp., observou-se uma maior quantidade populacional na rizosfera da Cevada com valores médios próximos dos valores médios da testemunha. Os demais tratamentos apresentaram valores médios aproximados.

De qualquer forma, em todos os tratamentos, verificou-se que a quantidade de colônias de Bacillus spp. antes mesmo da aplicação de efluente já era superior ao número de colônias de Pseudomonas. Esses dados estão de acordo com Stainer et al. (1966), de que os Bacillus spp. são resistentes ao calor e a outros agentes destrutivos devido a sua característica de 
formar endósporos. A maioria deles tem exigências nutricionais simples, requerendo no máximo alguns aminoácidos ou vitaminas B como fatores de crescimento.

$\mathrm{Na}$ Figura 5, verificam-se os valores médios do adensamento de colônias de Pseudomonas fluorescens e Bacillus spp. por tratamento, 20 dias após a primeira irrigação com o efluente e com 80 dias de ciclo vegetativo das culturas.

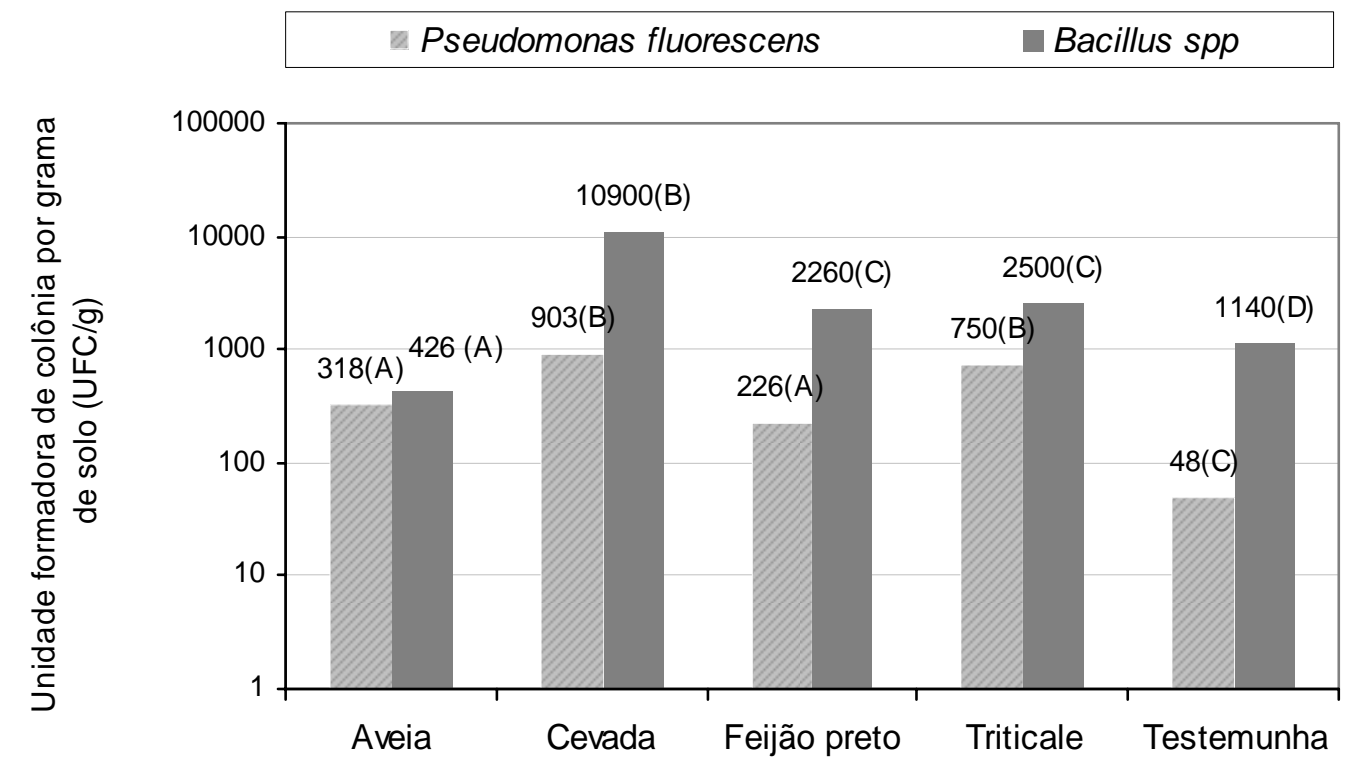

Tratamentos

Figura 5. Valores médios de Unidades formadoras de colônias de Pseudomonas fluorescens e Bacillus spp. na camada de $0-20 \mathrm{~cm}$ de profundidade de solo cultivado com diferentes culturas e testemunha, 20 dias após a primeira aplicação de efluente de esgoto doméstico tratado. Médias seguidas de letras maiúsculas iguais não diferem significativamente entre si pelo teste de Duncan a 5\% de probabilidade.

Os resultados obtidos mostraram um adensamento significativo de $P$. fluorescens em todos os tratamentos, inclusive o surgimento de colônias na testemunha de $48 \times 10^{4}$ unidades formadoras de colônias por grama de solo (UFCs.g ${ }^{-1}$ ). A cevada apresentou uma quantidade de $903 \times 10^{4}\left(\mathrm{UFC}^{-1}\right)^{-}$e o triticale de $750 \times 10^{4} \mathrm{UFC}^{-1}$; a aveia e o feijão preto apresentaram valores médios aproximados de 318 x10 ${ }^{4}$ UFC. g ${ }^{-1}$ e 226 x10 ${ }^{4}$ UFC.g $^{-1}$, respectivamente. Acredita-se que os adensamentos verificados em todos os tratamentos estejam relacionados ao aporte de matéria orgânica ao solo após a irrigação com o efluente de esgoto, além da liberação de grande quantidade de exsudados pelas rizosferas das plantas durante o desenvolvimento de seus ciclos vegetativos.

Esses resultados confirmam a afirmação de Stirling (1991), de que dentre as rizobactérias, o grupo das Pseudomonas fluorescentes é o mais consistentemente isolado, principalmente durante os períodos de grande produção de exsudados radiculares.

Em relação ao adensamento de Bacillus spp., verificou-se um notável crescimento do número de colônias nos tratamentos envolvendo solos cultivados, o que não ocorreu na testemunha. Uma possível hipótese para entendimento desse resultado é a de que o surgimento de colônias e $P$. fluorescens no solo sem cultivo tenha promovido uma competição, já anteriormente descrita, não somente entre P.fluorescens e Bacillus spp. e coliformes termotolerantes, como também, entre os dois gêneros de rizobactérias.

A Figura 6 mostra os valores médios de unidades formadoras de colônias de Pseudomonas fluorescens e Bacillus spp., obtidos 40 dias após a primeira irrigação com o 
efluente de esgoto tratado e com desenvolvimento de 100 dias de ciclo vegetativo das culturas.

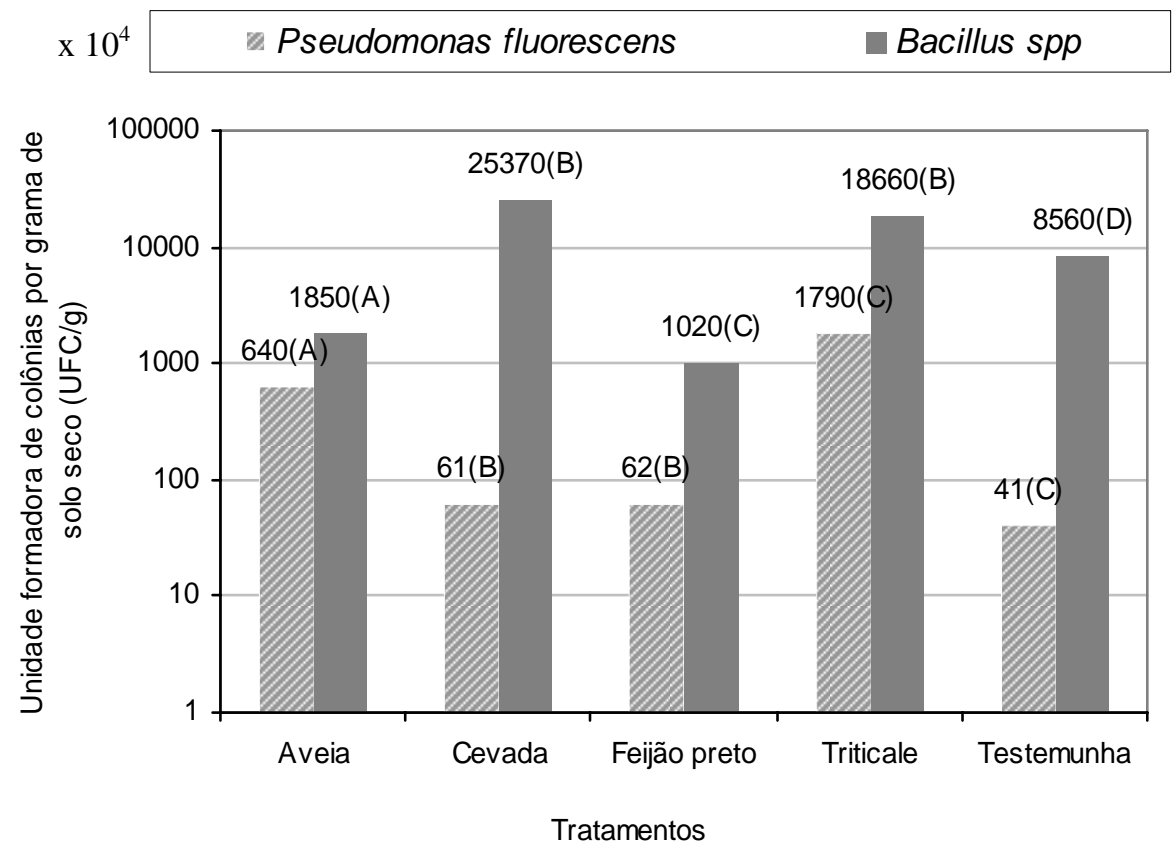

Figura 6. Valores médios de Unidades formadoras de colônias de Pseudomonas fluorescens e Bacillus spp. na camada de $0-20 \mathrm{~cm}$ de profundidade de solo cultivado com diferentes culturas e testemunha, 40 dias após a primeira aplicação de efluente de esgoto doméstico tratado. Médias seguidas de letras maiúsculas iguais não diferem significativamente entre si pelo teste de Duncan a 5\% de probabilidade.

Os resultados obtidos 40 dias após a primeira irrigação, equivalente a vinte dias após a segunda aplicação de efluente, mostraram que os tratamentos envolvendo a aveia e o triticale continuaram apresentando um aumento no adensamento de colônias de $P$. fluorescens, enquanto as rizosferas da aveia e feijão preto tiveram seu número de colônias significativamente reduzido, sendo de $903 \times 10^{4}$ para $61 \times 10^{4} \mathrm{UFc}^{-1}{ }^{-1}$ solo para a aveia e de $226 \times 10^{4}$ para $62 \times 10^{4}$ UFC.g ${ }^{-1}$ solo para o feijão preto. Na testemunha não ocorreu alteração significativa de valores médios.

Uma das hipóteses para a interpretação desses resultados seja a de que as análises realizadas 40 dias após a primeira aplicação coincidiram com 100 dias do ciclo vegetativo das culturas empregadas no experimento, visto que a família das gramíneas possui um ciclo de 120 dias e as leguminosas de 90 dias. Sendo assim, o feijão preto já se encontrava-se com seu ciclo vegetativo encerrado, enquanto a aveia, a cevada e o triticale ainda se encontravam na fase de amadurecimento. Entretanto, os resultados obtidos com a cevada, apesar de espécie vegetal da família das gramíneas, deve ter relação com uma redução acentuada e antecipada na produção de exsudados em relação à aveia e ao triticale.

Estes resultados atendem ao descrito por Clays-Josserand et al. (1995) de que o favorecimento de uma determinada espécie fluorescente de Pseudomonas spp. depende das características do solo e da espécie da planta e que seu desenvolvimento é maior na região das rizosferas do que em solos sem cultivo.

Coelho. (2006) detectaram que a rizosfera da alface favoreceu o crescimento de bactérias fluorescentes do gênero Pseudomonas, em comparação com o crescimento de Bacillus spp., que não foi beneficiado. Esse favorecimento foi detectado por comparação da rizosfera da alface com a da chicória (Cicorium endiva), rúcula (Eruca sativa), salsa (Petrosolium 
sativum) e tirica (Cyperus rotundus). Apenas a rizosfera da alface teve esse favorecimento. No entanto, a diversidade tanto de Bacillus spp. quanto de Pseudomonas spp. é influenciada pela rizosfera em que se desenvolvem (Coelho, 2006). A mesma conclusão chegaram Freitas e Vildoso (2004), em trabalho com três espécies cítricas (Citrus spp.).

Em relação ao Bacillus spp. manteve-se o adensamento em quase todos os tratamentos, após aplicação do efluente no solo, excluindo-se o feijão preto que apresentou uma redução de 50\% no valor médio de quantidade e colônias. Para esse resultado ainda não temos uma interpretação.

Acredita-se que a maior quantidade de rizobactérias Bacillus spp. verificada mesmo após o encerramento do ciclo das plantas, é uma resposta direta a maior resistência desse gênero formação de endósporos - à exposição aos raios solares.

Na Figura 7 são apresentados os resultados dos valores médios de unidades formadoras de colônias por grama de solo, obtidos nas análises microbiológicas de amostras de solo, 60 dias após a primeira irrigação com o efluente e com desenvolvimento de 120 dias de ciclo vegetativo das culturas.

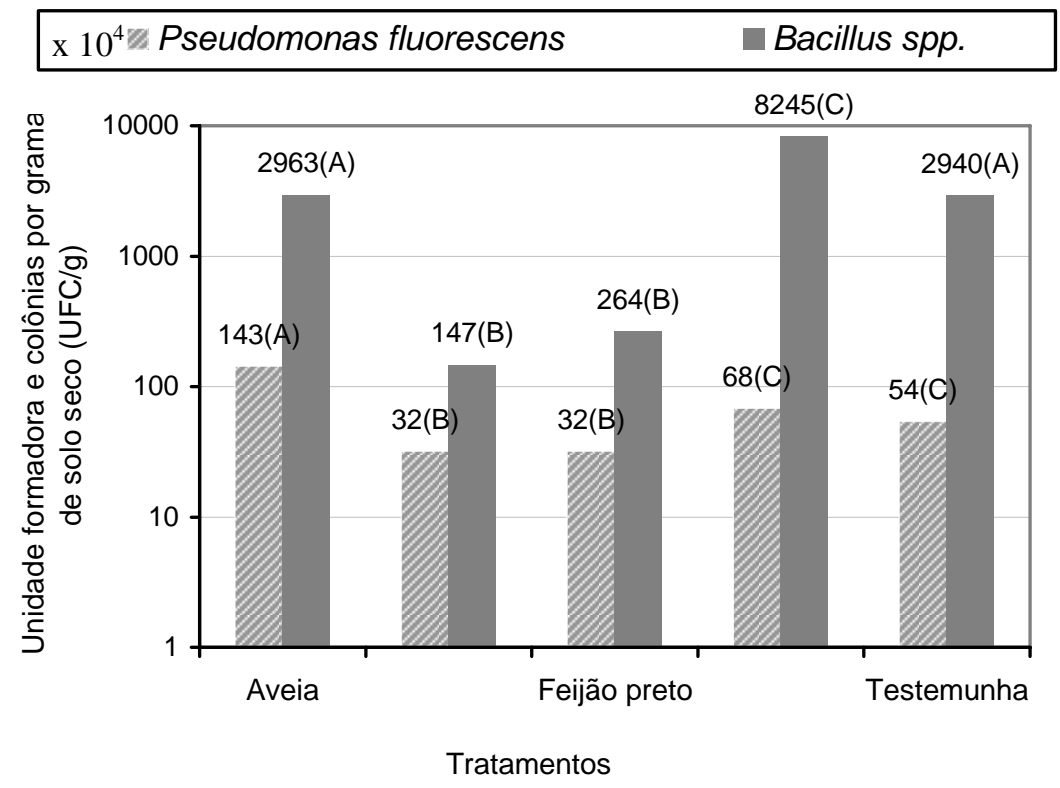

Figura 7. Valores médios de Unidades formadoras de colônias de Pseudomonas fluorescens e Bacillus spp. na camada de 0-20 cm de profundidade de solo cultivado com diferentes culturas e testemunha, 60 dias após a primeira aplicação de efluente de esgoto doméstico tratado. Médias seguidas de letras maiúsculas iguais não diferem significativamente entre si pelo teste de Duncan a 5\% de probabilidade.

Os resultados obtidos 60 dias após a primeira irrigação, ou seja, vinte dias após a terceira aplicação de efluente, indicaram uma notável redução no número de colônias de Pseudomonas fluorescens em quase todos os tratamentos, excluindo-se o tratamento testemunha, o qual não apresentou alterações significativas. Nessa época, todas as culturas já haviam encerrado seu ciclo vegetativo de 120 dias, portanto, estavam prontas para a colheita.

De acordo com estudos de Gamliel e Katan, (1991) a solarização do solo em campo reduziu significativamente populações de Pseudomonas fluorescens, entretanto, após o semeio de tomateiros em solos solarizados, a bactéria rapidamente colonizou a rizosfera e as raízes das plantas. Dessa forma, pode-se deduzir que a seção de produção de exsudados pelas rizosferas aliada à redução do sombreamento causado pelo secamento da plantas possibilitou 
uma maior exposição de área de solo à radiação solar, elevando a temperatura e colaborando para a redução de P.fluorescens.

Em relação à quantidade de Bacillus spp., assim como aconteceu com Pseudomonas fluorescens, verificou-se uma elevada redução de unidades formadoras de colônias nos tratamentos, excluindo-se a aveia, na qual se registrou um acréscimo de $1.8 \times 10^{4}$ para 2,9 $\mathrm{x} 10^{4} \mathrm{UFC}^{-1} \mathrm{~g}^{-1}$. Esse resultado também exige maior investigação para se chegar a uma interpretação conclusiva.

\section{CONCLUSÕES}

Concluiu-se com este experimento que o adensamento das rizobactérias Pseudomonas fluorescens e Bacillus spp. em unidades formadoras de colônias por grama de solo (UFCs.g ${ }^{-1}$ ) está diretamente relacionado à aplicação do efluente de esgoto tratado e, também, ao ciclo vegetativo das plantas.

A eficiência alcançada na redução da concentração de coliformes termotolerantes em número mais provável por $100 \mathrm{~mL}$ de água residuária (NMP.100 $\mathrm{mL}^{-1}$ ), após aplicação do efluente de esgoto no solo, pode estar relacionada à atuação das rizobactérias, por meio de predação, competição por espaço e nutrientes e atuação de sideróforos; pode também estar relacionada às substâncias exsudadas pelas rizosferas de diferentes culturas e, ainda, estar relacionada à influência de fatores físicos externos, principalmente, temperatura ambiente elevada e baixa umidade do solo.

\section{REFERÊNCIAS}

AMERICAN PUBLIC HEALTH ASSOCIATION (APHA). Standard methods for the examination of water and wastewater. 20. ed. Washington: APHA. AWWA. WEF, 2000 .

BECKER, J. O.; ZAVALETA-MEJIA, E.; COLBERT, S. F.; SCHROTH, M. N.; WEINHOLD, A. R.; HANDOCK, J. C.; VAN GUNDY, S. D. Effect of rhizobacteria on root-knot nematodes and gall formation. Annual Review of Phytopatholy, v. 78, p. 1466-1469, 1988.

BENITE, A. M. C.; MACHADO, S. P. Sideróforos: uma resposta dos microrganismos. Química Nova, Rio de Janeiro, v. 25, n. 6B, p. 1155-1164, 2002.

BUTLER, R. G.; ORLOB, G. T.; McGAUHEY, P. H. Underground movement of bacterial and chemical pollutants. Journal of the American Water Works, v. 46, p. 97-111, 1954.

CHERNICHARO, C. A. L. Princípios do tratamento biológico de águas residuárias: tratamentos anaeróbios. Belo Horizonte: Departamento de Engenharia Sanitária/UFMG, 1997. 246p. Vol. 5.

CLAYS-JOSSERAND, A.; LEMANCEAU, P.; PHILIPPOT, L.; LENSI, R. Influence of two plant species (flax and tomato) on the distribution of nitrogen dissimilative abilities within fluorescent Pseudomonas spp. Applied and Environmental Microbiology, v. 61, n. 5, p. 1745-1749, 1995.

COELHO, L. F. Interação de Pseudomonas spp. e de Bacillus spp. com diferentes rizosferas. 2006. 60f. Dissertação (Mestrado em Agricultura Tropical e Subtropical) Instituto Agronômico de Campinas IAC, Campinas, 2006. 
DINARDI, A. L. Fitorremediação: o uso de plantas na melhoria da qualidade ambiental. São Paulo: Oficina de Textos, 2007. p. 14.

FONSECA, M. C. C. Isolamento e caracterização morfológica de pseudomonas spp. Fluorescentes nativas em sistemas de produção agrícola. Seropédica: EMBRAPA Agrobiologia, 2000. Comunicado Técnico n. 43. p. l-4.

FREITAS, S. S.; VILDOSO, C. I. A. Rizobactérias e promoção do crescimento de plantas cítricas. Revista Brasileira de Ciência do Solo, v. 28, p. 987-994, 2004.

FREITAS, S. S.; SILVEIRA, A. P. D. Microbiota do solo e qualidade ambiental. Campinas: Instituto Agronômico de Campinas - IAC, 2007. 317p.

GAMLIEL, A.; KATAN, J. Involvement of fluorescent pseudomonads and other microorganisms in increases growth response of plants in solarizes soils. Annual Review of Phytopathology, v. 81, p. 494-502, 1991.

HABTE, M.; BYAPPANAHALLIU, M. N. Dependency of cassava. (Manihot sculenta Crantz) an vesicular-arbuscular mycorrhizal fungi. Mycorrhiza, v. 4, p. 241-245, 1994.

KÖPEN, W. Climatologia. México: Fondo de Cultura Económica, 1948.

McGAUHEY, P. H.; KRONE, R. B. Soil mantle as a wastewater treatment system. Sanitary Engineering Research Laboratory. Berkeley: University of California, 1967. Report n. 67-11.

SIKORA, R. A. Interrelationship between plant health promoting rhizobacteria, plant parasitic nematodes and soil microorganisms. Med. Fac. Kandbouww. Rijksuniv. Gent, v. 53, n. 2b, p. 867-878, 1992.

STAINER, R. Y.; PALLERONI, N. J.; DOUDOROFF, M. The aerobic Pseudomonads: a toxic study. Journal of General Microbiology, v. 43, p. 159-271, 1966.

SWIFT, M. J.; HEAL, O. W.; ANDERSON, J. M. Decomposition in terrestrial ecosystems. Oxford: Blacwell, 1979. 372p.

STIRLING, G. R. Biological control of plant parasitic nematodes: progress, problems and prospects. Wallingford: Oxon, 1991.

ZAVALETA-MEJIA, E.;VAN GUNDY, S. D. Effects of rhizobacteria on Meloidogyne infection. Journal of Nematology, n. 14, p. 475-476, 1982. 


ISSN = 1980-993X - doi:10.4136/1980-993X
www.agro.unitau.br/ambi-agua
E-mail: ambi-agua@agro.unitau.br
Tel.: (12) 3625-4116

\title{
Determinação de trechos de importância em sistemas de distribuição de água usando a vulnerabilidade hidráulica \\ (doi:10.4136/ambi-agua.64)
}

\section{Zacarías Navarro-Roa ${ }^{1}$; Maurício Luiz Sens²; Ramon Lucas Dalsasso ${ }^{3}$; Bruno Segalla Pizzolatti ${ }^{4}$}

\author{
Laboratório de Potabilização de Águas, Departamento de Engenharia Sanitária e Ambiental, \\ Universidade Federal de Santa Catarina \\ Caixa Postal 476, Florianópolis-SC, CEP88040-900, Brasil \\ E-mail: ${ }^{2}$ znavarroa1@hotmail.com; ${ }^{2} \mathrm{mls@ens.ufsc.br;}{ }^{3}$ dalsasso@ens.ufsc.br; ${ }^{4}$ brunosegalla@hotmail.com
}

\section{RESUMO}

Os sistemas de abastecimento de água, por sua configuração, tendem a ser vulneráveis aos perigos internos e externos, que têm o potencial de causar instabilidade na distribuição de água. A avaliação da vulnerabilidade é uma ferramenta que está sendo utilizada para garantir o abastecimento de água em diferentes cenários de falhas, podendo contribuir na busca de alternativas para fornecer água em situações de emergência. $O$ principal objetivo deste trabalho é determinar os trechos importantes ou críticos para um desempenho adequado do sistema de abastecimento de água, quando existem condições emergenciais como, por exemplo, as provocadas por desastres naturais. O desempenho hidráulico do sistema foi avaliado por meio de simulações em EPANET 2.0. A determinação da vulnerabilidade foi realizada por meio de uma aplicação programada em Visual Basic 6.0 e integrada EPANET por meio do módulo ferramenta (Toolkit-EPANET). A vulnerabilidade do sistema foi determinada com a interrupção de um trecho por vez e, desse modo, foi possível calcular, de uma forma dinâmica, a importância dos trechos para o sistema, e comparar esses resultados com o índice de importância relativa por vazão. Os resultados mostraram que a utilização dos índices de Vulnerabilidade-Sistema e Vulnerabilidade-Nó foi mais adequada para estabelecer a importância de um trecho crítico com relação ao desempenho de uma rede.

Palavras-chave: confiabilidade; emergência; sistema de abastecimento de água; vulnerabilidade.

\section{Determination of important pipes segments in water distribution systems using the hydraulic vulnerability}

\begin{abstract}
Water supply systems, due to their configuration, tend to be vulnerable to internal and external threats, which can potentially cause instability in water distribution. The vulnerability assessment is a tool that has been used to ensure the water supply in different failure scenarios, and can assist in seeking alternatives for supplying water in emergency situations. This work aimed mainly at determining the most important or critical segments for an adequate performance of the water supply system when there are emergency conditions such as the ones caused by natural disasters. The system's hydraulic performance was evaluated based on simulations using EPANET 2.0. The vulnerability was determined by using an application written in Visual Basic 6.0 to customize EPANET using its
\end{abstract}


Programmer's Toolkit. The system vulnerability was determined with the interruption of one segment at a time to calculate, in a dynamic way, the importance of each segment to the system, and by comparison of these results to the index of relative importance by flow rate. The results showed that using the indices Vulnerability-System and Vulnerability-Node was adequate to establish the importance of a critical segment in the performance of a network.

Keywords: reliability; emergency; water supply system; vulnerability.

\section{INTRODUÇÃO}

Os sistemas de abastecimento de água por sua extensão e configuração são afetados por problemas técnicos internos e externos, como, por exemplo: as falhas de equipamentos e os perigos naturais, respectivamente. As análises dos danos provocadoos por eventos naturais em diferentes lugares demonstram que os sistemas de abastecimento de água são suscetíveis aos impactos de perigos ambientais (Agardy e Ray, 2001; ALA, 2001).

A avaliacão da vulnerabilidade em sistemas de abastecimento de água está baseada na determinacão da influência de determinados trechos no comportamento de uma rede. Isso é realizado considerando-se a importância dos trechos segundo o diâmetro destes, o qual tem sido a base para a determinacão da importância desses componentes. No entanto, o uso do diâmetro como base do cálculo pode levar a resultados falsos, com relação à importância de um trecho.

O objetivo deste trabalho é determinar os trechos importantes ou críticos para um desempenho adequado do sistema de abastecimento de água, por meio da vulnerabilidade hidráulica do sistema. Para estabelecer a importância dos trechos foram comparadas duas alternativas. A primeira é a sugerida por Goulter e Bouchart (1990), comumente utilizada nas análises de vulnerabilidade em sistemas de abastecimento de água. Já a segunda, é a proposta neste artigo, em que é utilizada a análise hidráulica para definir os trechos de maior influência no desempenho adequado do sistema.

Em zonas com alto risco de desastres ou em grandes cidades é imprescindível a realização da avaliação de vulnerabilidade para garantir um abastecimento adequado nos cenários mais críticos para a distribuição de água. Entre os termos utilizados na avaliaçâo de vulnerabilidade estão o de perigo, o de desastre e o de vulnerabilidade propriamente dito.

Os perigos ambientais são eventos naturais ou antropogênicos que podem provocar danos importantes em sistemas humanos ou ecossistemas. Os desastres acontecem quando os danos provocados pelos perigos alteram o desenvolvimento normal de um sistema, da sociedade ou de ecossistemas. Os desastres estão relacionados com a intensidade dos perigos e com a vulnerabilidade dos sistemas e infra-estruturas, e a vulnerabilidade é a capacidade do sistema de resistir o impacto de um determinado perigo.

$\mathrm{Na}$ projeção de sistemas de abastecimento de água, utiliza-se o conceito de confiabilidade, como medida do desempenho do sistema, em diferentes condições de falhas em um tempo determinado. A confiabilidade é a probabilidade de satisfazer a demanda com pressão adequada para cada nó de consumo em condições anormais de operação (Misirdali, 2003; Ostfeld, 2001; Bao e Mays, 1990; Goulter e Bouchart, 1990). São conhecidos dois tipos de confiabilidade, a mecânica e a hidráulica. Em termos gerais, a vulnerabilidade é o complemento da confiabilidade (Mays, 2004), mas a vulnerabilidade refere-se a perigos e componentes específicos. Da mesma forma que a confiabilidade, existe a vulnerabilidade mecânica e a hidráulica. A vulnerabilidade mecânica corresponde à resistência de um componente ou infra-estrutura frente a determinados perigos. A vulnerabilidade hidráulica ou Vulnerabilidade-Sistema é definida como a probabilidade que o sistema não forneça a vazão total demanda em todos os nós de consumo para o tempo de análise. 
Nos casos de interrupção de um ou vários trechos, as ações corretivas dependem das condições físicas e hidráulicas do sistema e da vazão remanescente que este possa suprir depois do impacto de um fenômeno. Dessa forma, se for possível prever a vulnerabilidade do sistema frente aos perigos a que está exposto, determinando a vazão, a pressão e a qualidade da água que será disponibilizada aos usuários, também será possível prever recursos e ações que permitam satisfazer a demanda em uma situação de emergência.

A determinação do desempenho de uma rede de água é realizada por meio do algoritmo proposto por Gupta e Bhave (1996) e Ostfeld et al., (2002), que permite calcular a confiabilidade (vulnerabilidade hidráulica) quando um trecho está interrompido. A vulnerabilidade é o indicador da importância dos diferentes trechos para o sistema e para os nós. Os resultados são comparados com a proposta de Goulter e Bouchart (1990) para determinar a importância relativa de um trecho.

Goulter e Bouchart (1990) estabelecem a Equação 1 para determinar a importância relativa de um trecho em uma rede de distribuição de água. A Importância Relativa do Trecho $\left(\mathrm{IR}_{\mathrm{L}}\right)$ é a relação entre a vazão no trecho $\left(\mathrm{Q}_{\mathrm{L}}\right)$ e a vazão total da rede $\left(\mathrm{Q}_{\text {total }}\right)$.

$$
\mathrm{IR}_{\mathrm{L}}=\mathrm{Q}_{\mathrm{L}} / \mathrm{Q}_{\text {total }}
$$

A Equação 1 é pouco aplicável em redes malhadas, pois não considera a existência de vias alternativas para abastecimento em um determinado nó, ou seja, a redundância do sistema. Para considerar a redundância é preciso utilizar simulações hidráulicas que permitam comparar a disponibilidade de água nos nós de consumo de uma maneira dinâmica.

Para avaliar o comportamento hidráulico da rede, foi utilizado o software EPANET, o qual foi desenvolvido por Water Supply and Water Resources Division da Agência de Proteção Ambiental dos Estados Unidos de América (USEPA). O EPANET permite realizar simulações hidráulicas em redes de distribuição de água e comparar diferentes cenários de operação do sistema.

No EPANET 2.0, a demanda disponível no nó é satisfeita em todo momento, mas a pressão depende das condições do sistema e da demanda dos nós (Demand-Driven Analyses). Entretanto, a vazão disponível no nó depende da pressão. Por essa razão, em casos de falhas do sistema, é preciso realizar as correções das vazões calculadas por meio do EPANET 2.0. A Equação 2, proposta por Wagner et al. (1988), permite calcular a demanda disponível nos nós, considerando a pressão e a demanda requerida nestes (Wagner et al., 1988; Ostfeld et al., 2002; Wu e Walski, 2006).

$$
\begin{aligned}
& \mathrm{q}_{\mathrm{n}}^{\text {disp }}=0 \text { quando } \mathrm{P}_{\mathrm{n}} \leq 0 \\
& \mathrm{q}_{\mathrm{n}}^{\text {disp }}=\mathrm{q}_{\mathrm{n}}^{\text {req }}\left(\mathrm{P}_{\mathrm{n}} / \mathrm{P}_{\mathrm{n}}^{\text {min }}\right)^{0,5} \text { quando } 0<\mathrm{P}_{\mathrm{n}}<\mathrm{P}_{\mathrm{n}}^{\text {min }} \\
& \mathrm{q}_{\mathrm{n}}^{\text {disp }}=\mathrm{q}_{\mathrm{n}}^{\text {req }} \text { quando } \mathrm{P}_{\mathrm{n}} \geq \mathrm{P}_{\mathrm{n}}^{\min }
\end{aligned}
$$

em que: Pn é a pressão calculada pela simulação em cada estado, $\mathrm{P}_{\mathrm{n}}^{\min }$ é a pressão mínima; $\mathrm{q}_{\mathrm{n}}^{\text {disp }}$ é a demanda disponível e $\mathrm{q}_{\mathrm{n}}^{\text {req }}$ a demanda requerida no nó $\mathrm{n}$.

As Equações 3, 4, 5, 6, 7 e 8 foram propostas por Gupta e Bhave (1996) para determinar a confiabilidade em sistemas de abastecimento de água. Em que, Rnn, é a confiabilidade em nós; ${ }^{\mathrm{q} n, \mathrm{t}}$, é a vazão disponível no nó no instante $\mathrm{t}$; ${ }^{\mathrm{q} n, \mathrm{t}}$ é a vazão demandada no nó para um instante t; $t$ é o instante de simulação; Tno é o total de nós; e Ttotal é o tempo total de simulação. Com a Equação 3 é determinada a confiabilidade nos nós $\left(\operatorname{Rn}_{n}\right)$ e estabelece a relação entre a quantidade de água fornecida e a requerida em cada nó. 


$$
\mathrm{Rn}_{\mathrm{n}}=\sum_{\mathrm{t}=\mathrm{o}}^{\text {Ttotal }} \mathrm{q}_{\mathrm{n}, \mathrm{t}}^{\text {disp }} / \sum_{\mathrm{t}=0}^{\text {Ttotal }} \mathrm{q}_{\mathrm{n}, \mathrm{t}}^{\text {req }}
$$

A Equação 4 determina $\mathrm{Rv}$, que representa o fator de confiabilidade para vazão total no sistema durante o período de análise. Essa é a relação freqüentemente utilizada para definir a confiabilidade e avalia todo o volume movimentado no sistema durante o ciclo de simulação.

$$
\mathrm{Rv}=\sum_{\mathrm{t}=0}^{\text {Ttotal }} \sum_{\mathrm{n}}^{\text {Tno }} \mathrm{q}_{\mathrm{n}, \mathrm{t}}^{\text {disp }} / \sum_{\mathrm{t}=0}^{\text {Ttotal }} \sum_{\mathrm{n}}^{\text {Tno }} \mathrm{q}_{\mathrm{n}, \mathrm{t}}^{\text {req }}
$$

$\mathrm{O}$ déficit de água no tempo é medido com o fator de tempo nó $\left(\mathrm{Ft}_{\mathrm{n}}\right)$, que estabelece a média de tempo e, aproximadamente, $50 \%$ da vazão requerida no nó é considerada satisfatória. A Equação 5 é utilizada para calcular esse fator. Em que $a_{n, t}$ é a disponibilidade aceitável, e $\mathrm{a}_{\mathrm{n}, \mathrm{t}}=1$ se $\mathrm{q}_{\mathrm{n}, \mathrm{t}}^{\text {disp }} / \mathrm{q}_{\mathrm{n}, \mathrm{t}}^{\text {req }} \geq 0,5$ e $\mathrm{a}_{\mathrm{n}, \mathrm{t}}=0$ se $\mathrm{q}_{\mathrm{n}, \mathrm{t}}^{\text {disp }} / \mathrm{q}_{\mathrm{n}, \mathrm{t}}^{\text {req }}<0,5$ (Gupta e Bhave, 1996).

$$
\mathrm{Ft}_{\mathrm{n}}=\left(\sum_{\mathrm{t}=0}^{\text {Ttotal }} \mathrm{a}_{\mathrm{n}, \mathrm{t}}\right) / \text { Ttotal }
$$

O fator de tempo para o sistema (Ft) é a média de tempo em que a vazão para cada nó e cada instante $t$ foi satisfatória. A Equação 6 é utilizada para determinar o fator de tempo para o sistema, em que: Ft é o fator de tempo para o sistema; Tno, é o total de nós; e n, é o nó avaliado no instante $\mathrm{t}$.

$$
\mathrm{Ft}=\sum_{\mathrm{n}}^{\mathrm{Tno}} \mathrm{Ft}_{\mathrm{n}} / \mathrm{Tno}
$$

Gupta e Bhave (1996) consideram o Fator de Nó (Fn), dado pela Equação 7. Em que Tno é o número total de nós, e; $n$, o nó avaliado. Devido a esse fator ser a média geométrica de confiabilidade da vazão para o nó, é sensível à mínima confiabilidade dos nós.

$$
\mathrm{Fn}=\left[\prod_{\mathrm{n}=1}^{\mathrm{Tno}} \mathrm{Rn}_{\mathrm{n}}\right]^{1 / \text { Tno }}
$$

A Equação 8 é utilizada para determinar a confiabilidade hidráulica no sistema (Rnw), com limites de $0 \leq$ Rnw $\leq 1$.

$$
\mathrm{Rnw}=\mathrm{Rv} * \mathrm{Ft} * \mathrm{Fn}
$$

A Vulnerabilidade-Nó ( $\left.\mathrm{Vul}_{\mathrm{no}}\right)$ e a Vulnerabilidade-Sistema $\left(\mathrm{Vul}_{\text {sist }}\right)$ são definidas como o complemento da confiabilidade hidráulica para o nó e para o sistema, respectivamente. Nesse cálculo não é considerado o fator de nó (Fn). O Fn na Equação 8, nos casos em que as condições de falhas provocam falta de água em um nó por todo o tempo da simulação, tem valor de zero. Por essa razão no cálculo da importância de trecho o fator Fn não é considerado.

A importância de um trecho depende da vulnerabilidade que o mesmo provoca quando está interrompido durante a simulação. A Vulnerabilidade-Nó, ou seja, a probabilidade de que o nó $n$ não receba a vazão demandada no tempo de análise, pode ser determinada pela Equação 9. A Equação 10 pode ser utilizada para calcular a Vulnerabilidade-Sistema (Vul sist$_{\text {) }}$.

$$
\begin{aligned}
& \mathrm{Vul}_{\mathrm{no}}=\left(1-\mathrm{Ft}_{\mathrm{n}} * \mathrm{Rn}_{\mathrm{n}}\right) \\
& \mathrm{Vul}_{\mathrm{sist}}=(1-\mathrm{Ft} * \mathrm{Rv})
\end{aligned}
$$




\section{METODOLOGIA}

O algoritmo apresentado na Figura 1, foi utilizado para realizar as análises de vulnerabilidade do sistema. A programação dele foi realizada em Visual Basic 6.0 e integrado ao EPANET 2.0 por meio do módulo Toolkit, proporcionado por EPANET (Rossman, 2000). Os modos de operação-falha e não-falha foram simulados interrompendo um trecho por vez.

A determinação da importância de um trecho está baseada na comparação do funcionamento do sistema em condição de falha (interrupção da vazão do trecho) e em condição normal. Nesse sentido, a pressão mínima $\left(\mathrm{P}_{\mathrm{n}}^{\min }\right)$ é igual á pressão esperada segundo a simulação para condição normal ( $\left.\mathrm{P}_{\mathrm{n}, \mathrm{t}}^{\mathrm{req}}\right)$. Dessa forma, é possível observar o quanto o sistema se desvia da normalidade.

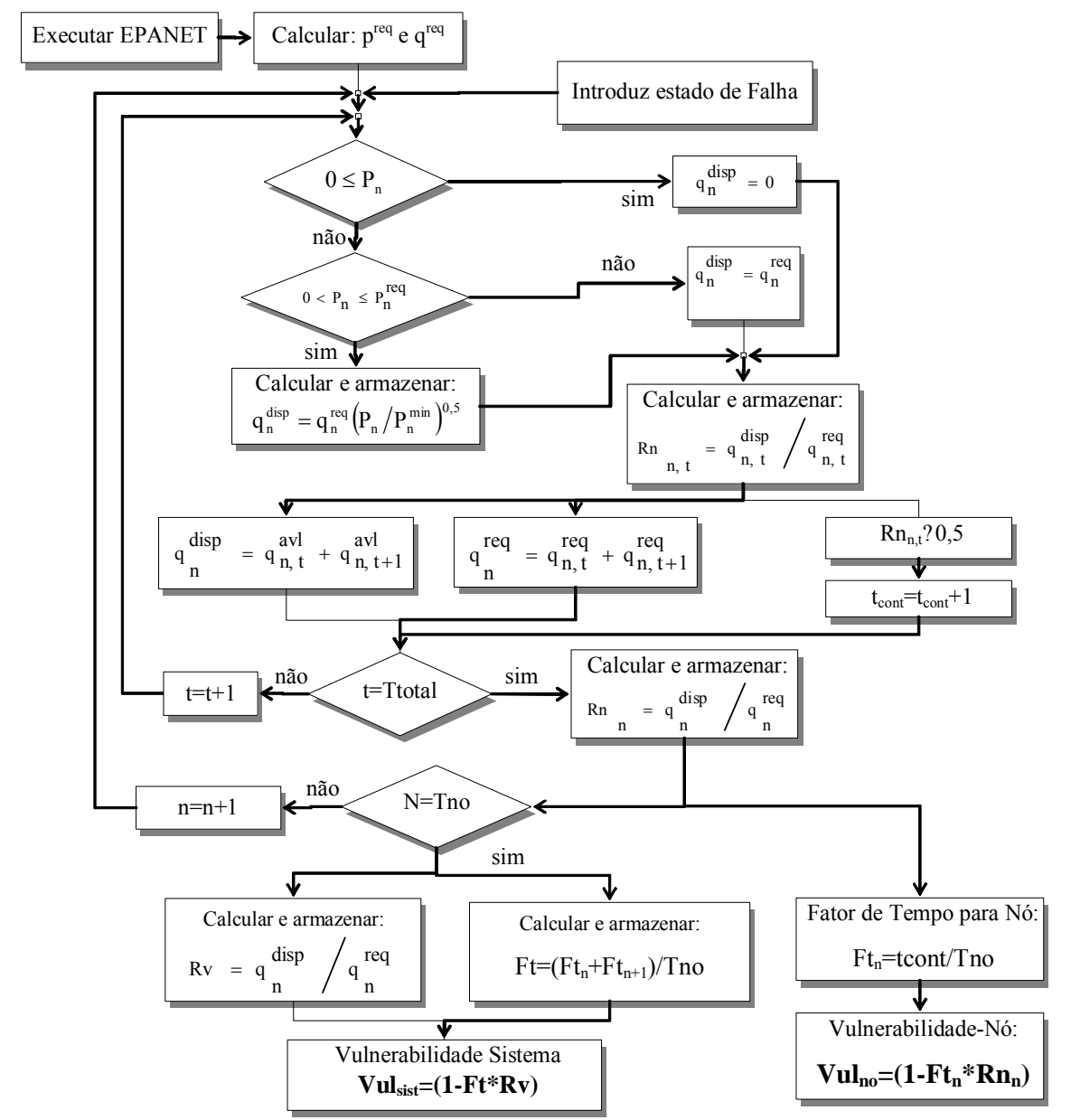

Figura 1. Algoritmo para determinar a vulnerabilidade de sistemas de água (adaptado de Ostfeld et al., 2002; Gupta e Bhave, 1996).

A vazão $\left(\mathrm{q}_{\mathrm{n}, \mathrm{t}}^{\mathrm{req}}\right)$ e a pressão $\left(\mathrm{P}_{\mathrm{n}, \mathrm{t}}^{\mathrm{req}}\right)$ requerida para cada nó em cada tempo foi calculada pela simulação em caso normal. A pressão disponível para cada nó em cada tempo $\left(\mathrm{P}_{\mathrm{n}, \mathrm{t}}^{\mathrm{disp}}\right)$ é determinada na simulação em estado de falha. A vazão disponível foi calculada utilizando-se a Equação 2, a partir da pressão disponível, a pressão requerida e a vazão requerida simuladas para cada hora em EPANET 2.0 com um trecho interrompido. 
Os trechos que provocam maior vulnerabilidade para um nó são os importantes para esse ponto de consumo. Entretanto, os que provocam maior vulnerabilidade para o sistema são os de maior importância para este.

Para determinar a vulnerabilidade de um sistema de água, foi utilizado o exemplo proposto por Rossman (2000), apresentado na Figura 2. Essa rede é simples e apresenta condições não necessariamente reais, no entanto, a configuração permite comparar facilmente os resultados.

\section{RESULTADOS E ANÁLISES}

O estudo avaliou a importância dos trechos para o desempenho do sistema em casos emergenciais. A Figura 2 representa o esquema e dados de entrada do exemplo proposto por Rossman (2000).

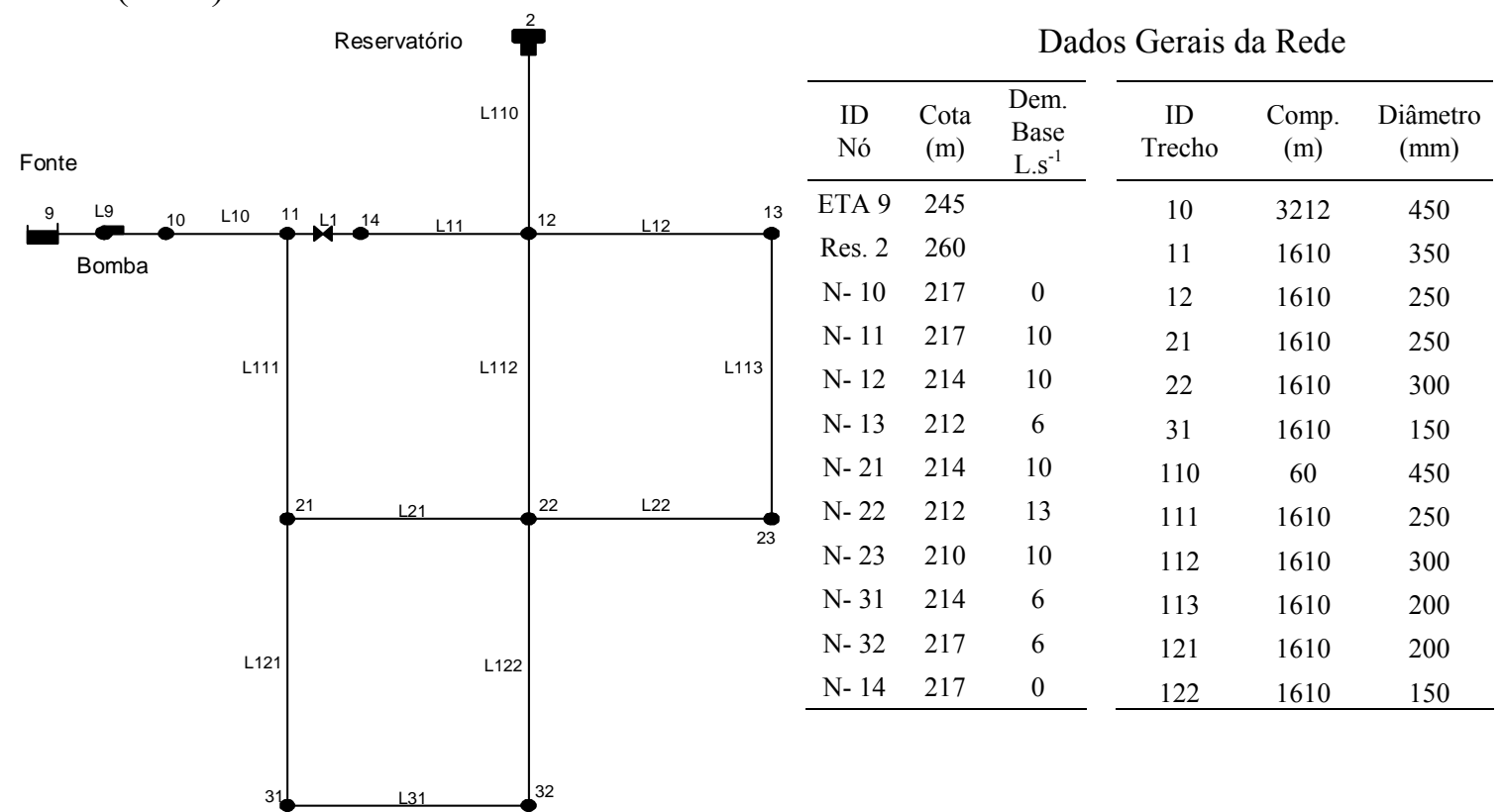

Figura 2. Esquema de rede de distribuição (Extraído de Rossman, 2000).

Na Tabela 1, observa-se o resultado da vulnerabilidade do sistema e dos nós para uma simulação de 5 dias (120 horas). Cada trecho permaneceu interrompido durante o tempo total de simulação. De acordo com a Vulnerabilidade-Sistema ( $\left.\mathrm{Vul}_{\text {sist }}\right)$, os 4 trechos mais importantes são: L-112, L-121, L-111 e L-11 com vulnerabilidade de 2,1\%, 1,9\%, 1,9\% e $0,7 \%$ respectivamente. Segundo IRL, os 4 trechos mais importantes são: L-11, L-111, L-112 e L-12 com importância de $21,5 \%, 10,7 \%, 10,1 \%$ e 5,3\%, no sistema. É preciso esclarecer que o trecho L-10 por ser a adutora era esperado uma alta vulnerabilidade, no entanto, não é considerado na análise de importância dos trechos. 
NAVARRO-ROA, Z.; SENS, M. L.; DALSASSO, R. L.; PIZZOLATTI, B. S. Determinação de trechos de importância em sistemas de distribuição de água usando a vulnerabilidade hidráulica. Ambi-Agua, Taubaté, v. 3, n. 3, p. 95-104, 2008. (doi:10.4136/ambi-agua.64)

Tabela 1. Vulnerabilidade-Nó, Vulnerabilidade-Sistema e $\mathrm{IR}_{\mathrm{L}}$.

\begin{tabular}{|c|c|c|c|c|c|c|c|c|c|c|c|}
\hline \multirow{2}{*}{$\begin{array}{c}\text { ID } \\
\text { Trecho }\end{array}$} & \multicolumn{8}{|c|}{ Vulnerabilidade-Nó $\left(\mathrm{Vul}_{\text {no }}\right)$} & \multirow{2}{*}{$\begin{array}{c}\text { Vul } \\
\text { Sist } \\
\%\end{array}$} & \multirow{2}{*}{$\begin{array}{c}\text { Vazão } \\
\text { Max } \\
\left(L . s^{-1}\right)\end{array}$} & \multirow[t]{2}{*}{$\begin{array}{c}\mathbf{I R}_{\mathbf{L}} \\
\%\end{array}$} \\
\hline & N-11 & $\mathrm{N}-12$ & $\mathrm{~N}-13$ & $\mathrm{~N}-21$ & $\mathrm{~N}-22$ & $\mathrm{~N}-23$ & $\mathrm{~N}-31$ & $\mathrm{~N}-32$ & & & \\
\hline L-10 & 99,80 & 99,80 & 99,80 & 99,80 & 99,80 & 99,80 & 99,80 & 99,80 & 99,80 & 120,08 & 37,20 \\
\hline L-11 & 0,21 & 1,33 & 1,14 & 0,12 & 0,88 & 0,93 & 0,12 & 0,54 & 0,68 & 69,51 & 21,50 \\
\hline L-12 & 0,15 & 0,10 & 1,23 & 0,32 & 0,36 & 0,61 & 0,34 & 0,37 & 0,40 & 16,97 & 5,30 \\
\hline L-21 & 0,18 & 0,38 & 0,43 & 0,03 & 0,51 & 0,49 & 0,06 & 0,21 & 0,30 & 4,86 & 1,50 \\
\hline L-22 & 0,04 & 0,06 & 0,53 & 0,02 & 0,02 & 1,41 & 0,03 & 0,03 & 0,27 & 9,43 & 2,90 \\
\hline L-31 & 0,05 & 0,06 & 0,06 & 0,05 & 0,07 & 0,07 & 0,01 & 1,24 & 0,16 & 3,31 & 1,00 \\
\hline L-110 & 0,00 & 0,00 & 0,00 & 0,00 & 0,00 & 0,00 & 0,00 & 0,00 & 0,00 & 4,08 & 1,30 \\
\hline L-111 & 0,16 & 0,92 & 1,32 & 3,22 & 2,07 & 1,97 & 3,05 & 2,96 & 1,89 & 34,57 & 10,70 \\
\hline L-112 & 1,10 & 0,67 & 1,28 & 2,51 & 2,93 & 2,80 & 2,69 & 2,97 & 2,12 & 32,46 & 10,10 \\
\hline L-113 & 0,09 & 0,05 & 0,03 & 0,14 & 0,15 & 0,20 & 0,15 & 0,17 & 0,12 & 6,57 & 2,00 \\
\hline L-121 & 0,20 & 0,24 & 0,25 & 0,06 & 0,28 & 0,27 & 10,77 & 8,41 & 1,90 & 13,71 & 4,20 \\
\hline L-122 & 0,09 & 0,06 & 0,05 & 0,11 & 0,05 & 0,05 & 1,01 & 3,06 & 0,42 & 7,09 & 2,20 \\
\hline
\end{tabular}

A Figura 3 (a) ilustra o comportamento da pressão e da demanda disponível e requerida para o nó N-32 com a interrupção do trecho L-121 durante o tempo total de simulação. A pressão disponível evidencia uma redução substancial, no momento mais crítico, em que a pressão disponível foi de $57 \mathrm{~m}$, reduzindo a vazão disponível em aproximadamente $15 \%$.

A Figura 3 (b) apresenta o comportamento da vazão e da pressão no nó N-31 quando L121 encontra-se interrompido. Para esse nó, o trecho L-121 se mostra muito importante, a maior Vunerabilidade-Nó ocorre nesse cenário de falha, com aproximadamente $11 \%$. A pressão disponível mínima no nó foi de $52 \mathrm{~m}$, reduzindo a vazão disponível em aproximadamente $20 \%$.

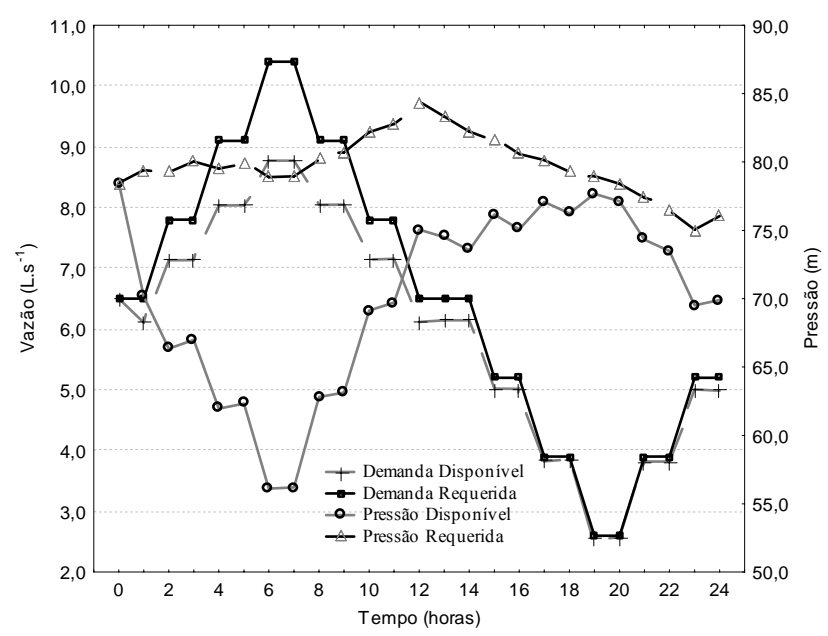

(a)

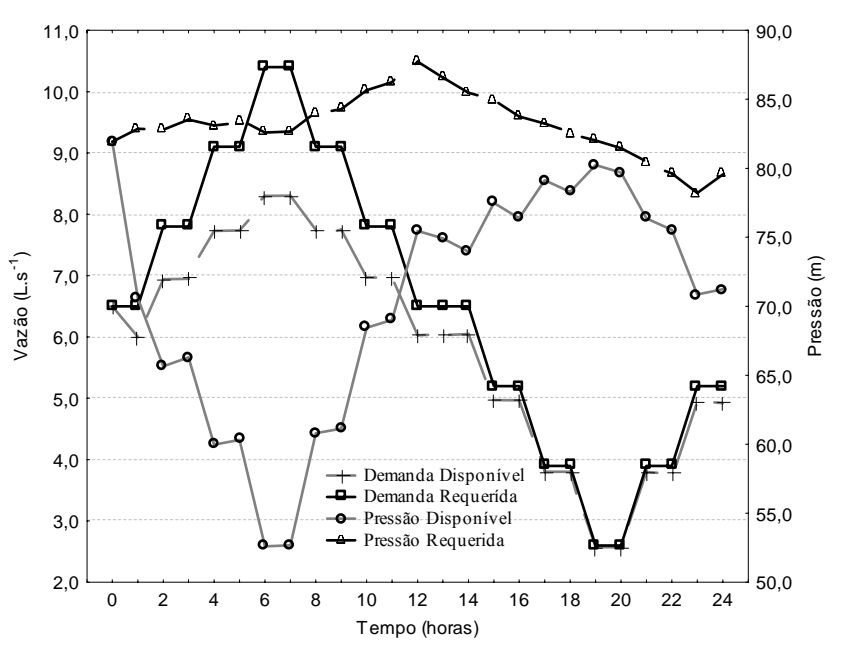

(b)

Figura 3. Comportamento da Demanda e Pressão no nó N-32 (a) e N-31(b) com interrupção do trecho L121.

Na Figura 4, observa-se o comportamento da vulnerabilidade nos nós de consumo com os 4 trechos de maior importância interrompidos. O impacto de L-121 nos nós N-31 e N-32 é o mais evidente; a interrupção dos trechos L-111 e L-112 provocou um desempenho relativamente similar, sendo os nós N-21, N-31 e N-32 os mais afetados. No caso do trecho L11 a vulnerabilidade nos nós foi considerada relativamente baixa, sendo os nós mais afetados o N-12, N-22, N-23 e N-32. 


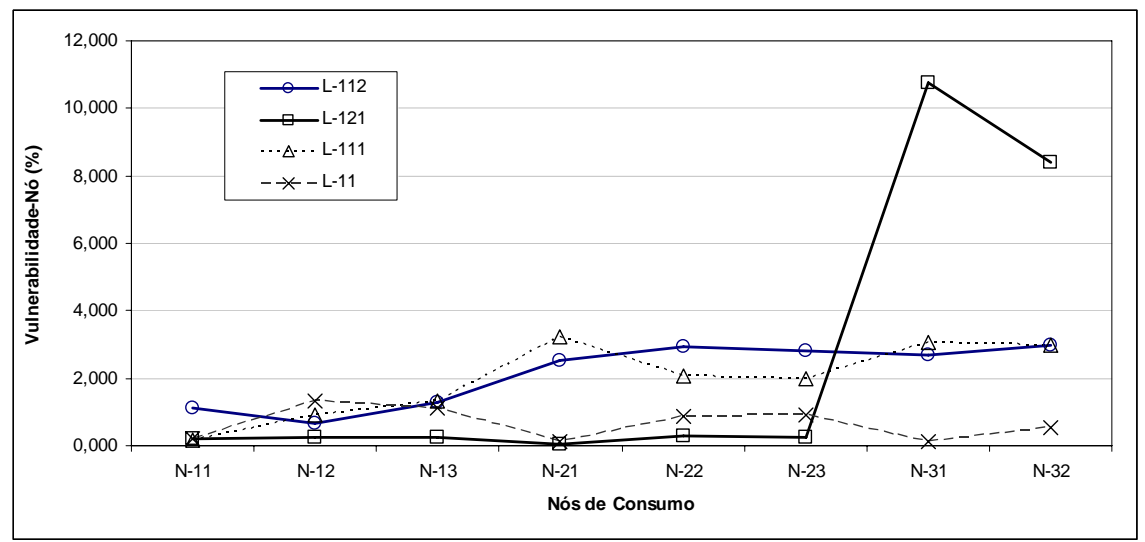

Figura 4. Vulnerabilidade-Nó com interrupção dos trechos L-112, L121, L-111 e L-11.

A Figura 5 permite comparar a importância dos trechos, no que diz respeito à Vulnerabilidade-Sistema e a Importância Relativa de Trecho. Segundo a Vul $\mathrm{Vist}_{\text {st }}$ o trecho considerado mais importante foi o L-112 e relativo ao $\mathrm{IR}_{\mathrm{L}}$, o de maior importância foi o trecho L-11. Para a rede analisada, os resultados apresentaram algumas coincidências. A $\mathrm{Vul}_{\text {Sist }}$ considerou os parâmetros hidráulicos em um determinado tempo, por isso esse índice é mais adequado para determinar a importância dos trechos.

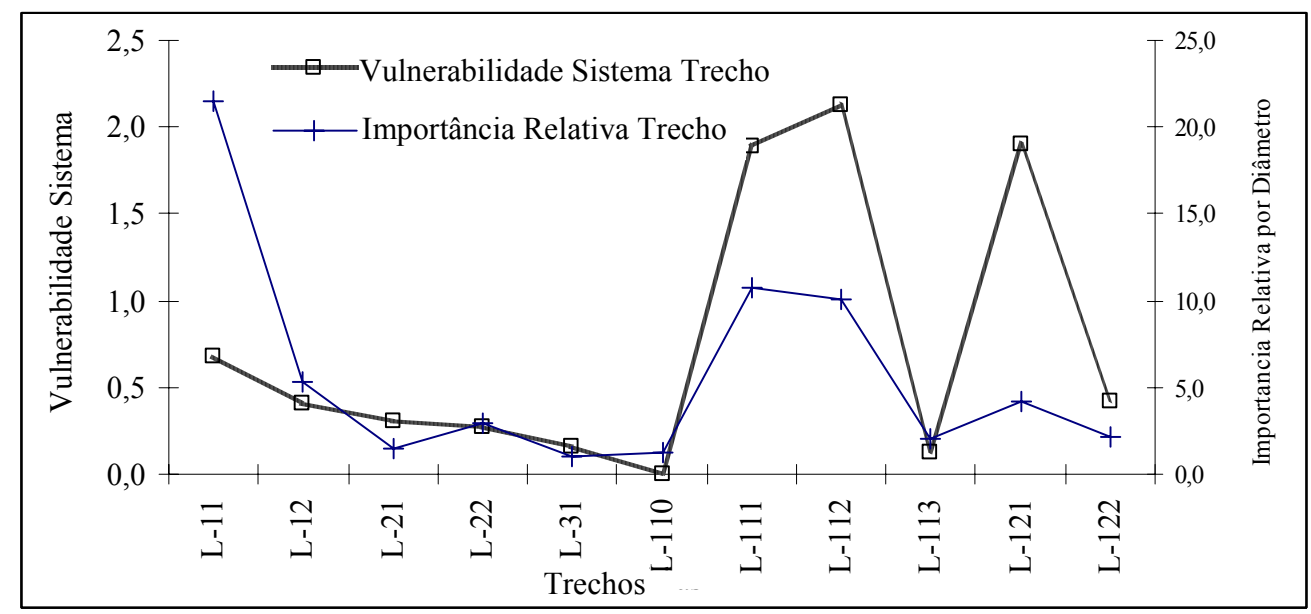

Figura 5. Vulnerabilidade do sistema com trechos interrompidos.

Os resultados demonstraram que a importância de um trecho dentro de uma rede malhada não depende somente da vazão que ela pode fornecer, mas também da configuração da rede, pois esta influencia na importância de cada componente. A aplicação da Vul $1_{\text {Sist }}$ tem maior relevância quando se considera o impacto que o trecho tem sobre um nó particular.

Na Figura 4, observou-se a importância do trecho L-121 para o abastecimento dos nós N31 e N-32. Utilizando a Vulnerabilidade-Nó, identificou-se quais nós foram mais afetados com a interrupção de um trecho. Os resultados obtidos com o cálculo da vulnerabilidade abrangeram a capacidade que o sistema tem de satisfazer a demanda em todos os nós. Por meio de uma análise dinâmica, foi possível ter um resultado mais representativo da realidade que ocorre no sistema, quando um trecho é interrompido por um período de tempo determinado. 
O fato de o trecho L-110 apresentar uma vulnerabilidade nula, não quer dizer que este não é importante para o funcionamento adequado do sistema. Esse resultado significa que, hipoteticamente, se esse componente for fechado, o abastecimento de água pode ser considerado satisfatório. É preciso ressaltar que esta análise não considerou aspectos econômicos, consumo de energia ou controle de pressões, evidenciando a relevância para o trecho L-110.

\section{CONCLUSÃO}

A metodologia permitiu determinar os trechos críticos para o funcionamento normal do sistema. Observou-se uma maior alteração no desempenho da rede, quando um desses trechos críticos é fechado para fins de manutenção ou por alguma situação de emergência provocada por condições extremas.

A determinação do trecho mais crítico para o funcionamento do sistema, sem considerar a adutora, tornou possível observar que, a importância de um trecho não necessariamente tem relação direta com o diâmetro dele. A determinação da importância de trecho, utilizando a vulnerabilidade total do sistema possibilitou uma análise de forma dinâmica, incluindo o abastecimento por trechos alternativos.

Por meio da determinação dos trechos importantes ou críticos, de acordo com a vulnerabilidade provocada por uma interrupção no sistema, obtiveram-se os nós que são mais afetados com o fechamento. Uma análise deste tipo pode ser aplicada na programação de ações que permitam satisfazer a demanda de água em casos de emergências.

A utilização dos índices de Vulnerabilidade-Sistema $\left(\mathrm{Vul}_{\text {sist }}\right)$ e Vulnerabilidade-Nó $\left(\mathrm{Vul}_{\mathrm{no}}\right)$ foi mais adequada para estabelecer a importância de um trecho no que se refere ao desempenho da rede de abastecimento, pois o índice Importância Relativa do Trecho $\left(\mathrm{IR}_{\mathrm{L}}\right)$ não considera a redundância do sistema.

\section{AGRADECIMENTOS}

Os autores agradecem ao programa de bolsa da Organização de Estados Americanos -OEA-LASPAU; ao programa de bolsa da Secretaria de Estado de Educação Superior, Ciência e Tecnologia da República Dominicana; e, à Coordenação de Aperfeiçoamento de Pessoal de Nível Superior do Brasil -CAPES.

\section{REFERÊNCIAS}

AGARDY, F. J.; RAY, A. D. Emergency planning for water utility management (M 19). 3. ed. Denver: Americam Water Works Association, 2001.

AMERICAN LIFELINES ALLIANCE - ALA. Seismic fragility formulations for water systems: part 1. Federal Emergency Management Agency (FEMA) e American Society of Civil Engineers (ASCE). 2001. 96p. Disponível em: <www.americanlifelinesalliance.org>. Acesso em: junho 2008.

BAO, Y.; MAYS, L. Model for water-distribution system reliability. Journal of Hydraulic Engineering, v. 116, n . 9, p. 1119-1137, 1990.

GOULTER, I. C.; BOUCHART, F. Reliability-constrained pipe network model. Journal of Hydraulic Engineering, v. 116, n. 2, p. 211-229, 1990. 
GUPTA, R.; BHAVE, P. Reliability-based of water-distribution systems. Journal of Environmental Engineering, v. 122, n. 1, p. 51-54, 1996.

MAYS, L. W. Vulnerability assessment, emergency response planning: summary of what's available. In: Water supply systems security. New York: McGraw-Hill, 2004. Cap. 3. Disponível em: <www.digitalengineeringlibrary.com>. Accesso em: junho 2006.

MISIRDALI, M. A methodology for calculating hydraulic system reliability of water distribution networks. 2003. 104f. Thesis (Master of Science) - School Of Natural And Applied Sciences, The Middle East Technical University, Ankara, 2003.

OSTFELD, A. Reliability analysis of regional water distribution systems. Urban Water, v. 3 , p. 253-260, 2001.

OSTFELD, A.; KOGAN, D.; SHAMIR, U. Reliability simulation of water distribution systems - single and multiquality. Urban Water, v. 4, p. 53-61, 2002.

ROSSMAN, L. A. EPANET 2: users manual. Cincinnati: U.S. Environmental Protection Agency, 2000.

WAGNER, J.; SHAMIR, U.; MARKS, D. Water distribution reliability: simulation methods. Journal of Water Resources Planning and Management, v. 114, n. 3, p. 276-294, 1988.

WU, Z. Y.; WALSKI, T. M. Pressure dependent hydraulic modelling for water distribution systems under abnormal conditions. In: IWA WORLD WATER CONGRESS, Sept.1014, 2006, Beijing. Proceedings... IWA, 2006. 


\begin{tabular}{ccc|} 
ISSN = 1980-993X - doi:10.4136/1980-993X \\
www.agro.unitau.br/ambi-agua \\
E-mail: ambi-agua@agro.unitau.br \\
Tel.: (12) 3625-4116
\end{tabular}

\title{
Economia de água na irrigação do coqueiro em função de áreas de maior concentração do sistema radicular e cobertura do solo (doi:10.4136/ambi-agua.65)
}

\author{
Ivandelson Siqueira Santos ${ }^{1}$; Carlos Alberto Vieira de Azevedo ${ }^{2}$; Hugo Orlando \\ Carvallo Guerra'; Frederico Antônio Loureiro Soares ${ }^{3}$; Vera Lucia Antunes de Lima²; \\ José Dantas Neto ${ }^{2}$ \\ ${ }^{1}$ Mestre em Eng. Agrícola, R. Antonio José Rodrigues, 81, Mirante, CEP 58104-320, Campina Grande, PB \\ E-mail: ivandelson@bol.com.br \\ 22DEAg/CTRN/UFCG. Av Aprígio Veloso, 882, Bodocongó, CEP 58109-970, Campina Grande, PB \\ Email: \{cazevedo, antunes, zedantas\}@deag.ufcg.edu.br; hugo_carvallo@hotmail.com \\ ${ }^{3}$ Instituto CENTEC. Av. Dr. Guarani, 313, Bairro Betânia, CEP 62040-730, Sobral, CE \\ E-mail: fredalsoares@hotmail.com
}

\section{RESUMO}

A produção brasileira de coco não tem sido suficiente para atender a demanda do mercado interno, o que tem obrigado a importar volumes expressivos de coco seco e semiindustrializado (IBGE, 2006). Como a região Nordeste destaca-se com a maior produção e é caracterizada por uma elevada evapotranspiração e baixa precipitação, faz-se necessário otimizar a utilização da água usada na irrigação do coqueiro. Na fase de desenvolvimento do coqueiro grande parte do sistema radicular se concentra lateralmente em até $1 \mathrm{~m}$ de raio, chegando na fase adulta a um raio de até $2 \mathrm{~m}$. O cálculo do volume de água aplicado na irrigação é normalmente calculado, considerando-se a área determinada pelo espaçamento da cultura e um coeficiente de cobertura de sua copa, o que faz com que grandes volumes de água sejam aplicados. Visando economizar água, esta pesquisa teve como objetivo calcular o volume de água de irrigação utilizando ás áreas de maior adensamento do sistema radicular. Para o primeiro ano de desenvolvimento da cultura do coqueiro, foram irrigadas, no campo, 4 bacias, delimitadas por anéis de zinco com os diâmetros de 0,7; 0,8; 0,9 e 1,0 m, consideradas de maior concentração do sistema radicular, e duas condições de cobertura de solo (coberto e $\mathrm{nu})$, mais uma testemunha $(4 \times 2+1)$, perfazendo nove tratamentos com três repetições, totalizando 27 parcelas. O cálculo do volume de água de irrigação na cultura do coqueiro, baseado nas áreas de maior concentração do sistema radicular, promoveu considerável economia de água com valores máximos e mínimos, respectivamente, de 93,95 e 87,62\%, na condição de solo sem cobertura e de 96,98 e 93,81\%, em solo com cobertura., em relação ao procedimento tradicionalmente utilizado. A cobertura da superfície do solo contribuiu para uma redução substancial do volume de água utilizado pelo coqueiro.

Palavras-chave: eficiência no uso da água; Cocos nucifera; área molhada.

\section{Coconut irrigation water saving as a function of areas of the concentration of the root system and soil cover}

\section{ABSTRACT}

The Brazilian production of coconut has not been sufficient to attend the internal market demand which has resulted in great importations of dry and semi industrialized coconut 
(IBGE, 2006). The northeast of Brazil has the greatest coconut production and is, at the same time, characterized for its high evapotranspiration demand and the lowest precipitation, therefore, it is necessary to optimize the irrigation water used. During the development phase of the coconut tree, most of the root system concentrates around $1 \mathrm{~m}$ of radius, and in the adult phase, in larger part, to a radius up to $2 \mathrm{~m}$. The traditional procedure of calculation of the water volume to be applied through irrigation, normally considers the area given by the crop planting spacing and a canopy cover coefficient. This results in great volumes of water applied unnecessarily. To save water, this study investigates the calculation of the volume of irrigation water considering the areas where larger concentration of the root system occurs. For the first year of development of the coconut tree, four areas of irrigation delimited by rings of zinc with diameters of $0.7 \mathrm{~m}, 0.8,0.9$ and $1.0 \mathrm{~m}$ were used to irrigate the portion with the larger concentration of the root system, and two conditions of soil covering (covered and bare soil), plus a control $(4 \times 2+1)$, resulting in nine treatments with three repetitions, totaling 27 plots. The procedure proposed in this research for the calculation of the water volume to be applied in the coconut crop, based on areas of larger concentration of the root system, promoted considerable economy of water, in relation to the procedure traditionally used. The isolation of the soil surface in order to avoid the evaporation contributed to a substantial reduction of the applied volume of water as well.

Keywords: irrigation; Cocos nucifera; wetted area.

\section{INTRODUÇÃO}

O coqueiro (Cocos nucifera L.) foi introduzido no Brasil em 1553, procedente da ilha de Cabo Verde, sendo no Nordeste onde a espécie encontrou melhor adaptação. O coqueiroanão, com aptidão para água ou coco verde, foi introduzido somente em 1925 (Ferreira et al., 1997). A região Nordeste é onde está concentrada a maior produção de coco do país. Em 2002, com uma produção de 1.928.236 milhões de frutos, essa região respondeu por $79 \%$ da produção nacional de coco (IBGE, 2006).

A produção brasileira, entretanto, não tem sido suficiente para atender à demanda do mercado interno, o que tem resultado, como conseqüência, em importações de volumes expressivos de coco seco e semi-industrializado (IBGE, 2006). Como a região Nordeste destaca-se com a maior produção e esta é caracterizada por ter maior evapotranspiração e menor precipitação, faz-se necessário aperfeiçoar os sistemas de irrigação e diminuir os grandes volumes de água hoje aplicados na agricultura.

A cultura do coco exige durante seu crescimento vegetativo e fase de produção grande quantidade de água de boa qualidade; sendo assim, dificilmente se encontrará água disponível em quantidades adequadas para atender à demanda evapotranspirativa em condições de cultivo em sequeiro. O regime pluvial ideal é aquele que apresenta precipitação média anual de $1500 \mathrm{~mm}$, com valores mensais nunca inferiores a $130 \mathrm{~mm}$. Um período de três meses, com menos de $50 \mathrm{~mm}$ de precipitação por mês, é essencialmente prejudicial ao coqueiro (Ferreira et al., 1997).

Estudos realizados por Miranda et al. (1999) em Paraípaba, CE, indicaram que, plantas jovens de coqueiro-anão irrigadas por micro aspersão, o consumo de água variou de 8 a $12 \mathrm{~L}$ por planta por dia nos primeiros 6 meses após o plantio (com até $10 \%$ da superfície do solo coberta pela cultura), de 12 a $28 \mathrm{~L}$ por planta por dia dos 7 aos 12 meses (10 a $16 \%$ de cobertura do solo), de 30 a 100 L por planta por dia dos 13 aos 24 meses de idade (16 a 36\% de cobertura do solo) e de 103 a 173 L por planta por dia dos 25 a 36 meses (36 a 64\% de 
cobertura do solo). A grande maioria dos estudos a respeito das necessidades hídricas do coqueiro tem sido realizada nas condições edafo-climáticas da Ásia, utilizando variedades gigantes. No entanto, no Brasil, a maior parte dos plantios irrigados de coqueiro utiliza a variedade anã, e assim os estudos encontram-se ainda em fase inicial. Dispor de dados sobre o sistema radicular do coqueiro é essencial para o dimensionamento e manejo da irrigação. A falta dessas informações faz com que o volume de água aplicado seja inadequado. Por outro lado o manejo da irrigação pode também interferir na formação do sistema radicular (Nogueira et al., 1997).

O uso de cobertura de plástico tem apresentado importantes resultados econômicos, uma vez que evitam capinas e se diminuem às perdas de água por evaporação, constituindo-se, assim, uma importante alternativa para economia de água na agricultura, principalmente, para as regiões semi-áridas, onde ocorrem baixos índices de precipitação e elevadas temperaturas Cermeño (1990) e Sganzerla (1991), constataram que melhores resultados foram conseguidos com filmes de polietileno que com materiais vegetais.

No Brasil, os primeiros registros da utilização de filmes de polietileno datam de 1967, no cultivo de morango (Goto, 1997). Nos últimos anos, o uso dos filmes tem-se expandido para o cultivo de diversas hortaliças, como pimentão, tomate, pepino, melão e abobrinha. Pinto (1997) trabalhando com diferentes tipos de cobertura de polietileno, com a cultura de alface, concluiu que em média, a evapotranspiração nos tratamentos com mulch de polietileno apresentou-se 25\% menor que nos tratamentos sem mulch.

Esta pesquisa teve como objetivo avaliar, sob condições de solo coberto com plástico e de solo nu, volumes de água, a ser aplicado na cultura do coqueiro-anão que consideram apenas a área de maior concentração do sistema radicular, visando a sua formação num determinado volume de solo delimitado por anéis de zinco.

\section{MATERIAL E MÉTODOS}

O experimento foi conduzido no município de Pocinhos, $\mathrm{PB}$, situado nas coordenadas $36^{\circ} 06^{\prime} 34^{\prime \prime}$ Oeste e $7^{\circ} 07^{\prime} 12^{\prime}$ ' Sul, com solos classificados como Neossolo textura média fase caatinga hiperxerófila relevo plano e suave ondulado e Litólico Eutrófico com fraca textura arenosa e/ou média fase pedregosa e rochosa caatinga hiperxerófila relevo suave ondulado substrato gnaisse e granito (EMBRAPA, 1999). O solo utilizado na presente pesquisa foi o Neossolo.

O delineamento experimental foi em blocos ao acaso, resultante das combinações fatoriais entre as quatro áreas delimitadas por anéis de zinco com diâmetros de 0,7;0,8; 0,9 e $1,0 \mathrm{~m}$, nas quais a água foi aplicada, e duas condições de cobertura de solo: coberto (CC) e solo nu (SC), mais uma testemunha $(4 \times 2+1)$, perfazendo nove tratamentos com três repetições, totalizando vinte e sete parcelas.

A testemunha foi uma bacia de irrigação com características, medidas e manejo idênticos às utilizadas pelos agricultores da região; uma bacia sem cobertura de solo, de 1,0 m de diâmetro irrigada diariamente com uma media de 43 litros de água.

Os anéis de zinco foram enterrados no solo $0,20 \mathrm{~m}$, deixando acima da superfície do solo uma altura de $0,35 \mathrm{~m}$. A área onde foi instalado o experimento foi dividida em 3 blocos, correspondendo às 3 repetições, cada uma com dimensões de 32 x $40 \mathrm{~m}$, possuindo 9 plantas, totalizando $1280 \mathrm{~m}^{2}$. Todos os blocos foram separados por uma bordadura de 9 plantas.

No meio da área do experimento enterrou-se uma tubulação com 12 pontos de distribuição de água, nos quais se conectava uma mangueira de plástico flexível de $50 \mathrm{~m}$ de comprimento fazendo a irrigação manualmente, usando como medida de volume de água um 
balde de plástico graduado em litros. A água de irrigação usada no experimento era proveniente de um poço tubular provido de catavento, com $55 \mathrm{~m}$ de profundidade e diâmetro de $150 \mathrm{~mm}$, que abastecia uma caixa de água com capacidade para $5 \mathrm{~m}^{3}$, situado a uma distância de $120 \mathrm{~m}$ da fonte de água. Inicialmente, o solo foi colocado a capacidade de campo, saturando para isso o solo e deixando drenar durante 24 horas.

Nos tratamentos com cobertura o solo foi coberto com uma lâmina de polietileno de dupla face (preta e branca), com a parte branca virada para cima para refletir a luz do sol, amenizando, assim, a alta temperatura no solo, e a parte de cor preta ficou virada para baixo para que o calor naquela região fosse absorvido.

O plantio foi realizado utilizando-se mudas com 6 meses de idade, apresentado raízes nuas e podadas no momento de serem plantadas, tratadas contra fungos e bactérias. Antes do plantio, as mudas permaneceram 10 dias na área experimental para adaptação climática e logo depois foi feito o plantio em covas espaçadas de $8 \mathrm{~m}$ entre linhas e $8 \mathrm{~m}$ entre fileiras com dimensões de $0,5 \times 0,5 \times 0,7 \mathrm{~m}$.

O volume de água de irrigação foi calculado conforme a equação [1] que substitui a equação de Howel e Hiller (1972) comumente usada.

$$
\mathrm{V}=\frac{3,14 \mathrm{R}^{2} \mathrm{~K}_{\mathrm{c}} \mathrm{K}_{\mathrm{p}} \mathrm{E}_{\mathrm{v}}}{\mathrm{E}_{\mathrm{a}}}
$$

em que:

$\mathrm{V}=$ Volume de água aplicado, $\mathrm{L}$ planta ${ }^{-1} \mathrm{dia}^{-1}$;

$\mathrm{R}$ = Raio do anel de zinco, em $\mathrm{m}$

Kc = Coeficiente de cultura;

$\mathrm{Kp}=$ Coeficiente do Tanque Classe A;

$\mathrm{Ev}$ = Evaporação do Tanque Classe A, mm;

Ea = Eficiência de aplicação de água.

Essa equação considera as áreas de maior concentração do sistema radicular do coqueiro.

A equação de Howell e Hiller que considera o espaçamento entre fileiras e plantas do coqueiro foi utilizada para calcular o volume de água aplicado na testemunha. Dada a dificuldade de se medir a evapotranspiração do solo coberto, este foi irrigado a cada 2 dias, assumindo-se assim que o consumo deste seria de $50 \%$ do solo sem cobertura. A irrigação nos tratamentos sem cobertura do solo foi diária é igual ao volume calculado pela equação [1].

$\mathrm{O}$ valor do Kc adotado para os 120 dias em que durou o experimento foi de 0,4, e o coeficiente de cobertura Cv de 20\%, conforme Nogueira et al. (1998). A evaporação Ev foi medida pelo uso de um Tanque Classe A instalado na área do experimento. A eficiência de aplicação de água foi considerada $100 \%$, uma vez que a água foi aplicada manualmente com um balde de plástico graduado em litros. O cálculo do volume de água a ser aplicado foi baseado em áreas de maior concentração do sistema radicular do coqueiro. Para tal, avaliaram-se 4 diferentes áreas delimitadas pelos anéis de zinco.

Os volumes de água aplicados e os parâmetros de crescimento do coqueiro (altura de plantas e diâmetro do caule) foram avaliados mediante análise de variância com teste $\mathrm{F}$ para os fatores diâmetro da área irrigada e condição de solo, segundo Ferreira (1991) e Santos et al. (1998). O fator quantitativo, área irrigada, foi submetido a análises de regressão. 


\section{RESULTADOS E DISCUSSÃO}

A Tabela 1 mostra um resumo das análises de variância e as médias da altura das plantas do coqueiro para os tratamentos estudados.

Tabela 1. Análise de variância para a altura das plantas do coqueiro para os diferentes diâmetros das áreas irrigadas e condições de cobertura do solo.

\begin{tabular}{|c|c|c|c|c|c|c|}
\hline \multirow{2}{*}{ Causas de Variação } & \multirow{2}{*}{ GL } & \multicolumn{5}{|c|}{ Quadrados médios } \\
\hline & & O DAT & 30 DAT & 60 DAT & 90 DAT & 120 DAT \\
\hline Diâmetro (D) & 3 & $897,01^{\mathrm{ns}}$ & $766,13^{\mathrm{ns}}$ & $738,79^{\mathrm{ns}}$ & $701,46^{\mathrm{ns}}$ & $711,79^{\mathrm{ns}}$ \\
\hline Condiç̧̃̃es de Solo (CS) & 1 & $260,04^{\mathrm{ns}}$ & $345,80^{\mathrm{ns}}$ & $227,55^{\mathrm{ns}}$ & $225,71^{\mathrm{ns}}$ & $247,04^{\mathrm{ns}}$ \\
\hline Interação D x CS & 3 & $510,32^{\mathrm{ns}}$ & $493,99^{\mathrm{ns}}$ & $446,02^{\mathrm{ns}}$ & $450,09^{\mathrm{ns}}$ & $458,82^{\mathrm{ns}}$ \\
\hline Testemunha x Fatorial & 1 & $159,47^{\mathrm{ns}}$ & $140,97^{\mathrm{ns}}$ & $223,06^{\text {ns }}$ & $230,23^{\mathrm{ns}}$ & $237,72^{\mathrm{ns}}$ \\
\hline Blocos & 2 & $612,71^{\mathrm{ns}}$ & $506,83^{\mathrm{ns}}$ & $417,29^{\mathrm{ns}}$ & $411,70^{\mathrm{ns}}$ & $407,86^{\mathrm{ns}}$ \\
\hline Resíduo & 16 & 383,12 & 432,30 & 405,38 & 393,42 & 390,67 \\
\hline $\mathrm{CV}(\%)$ & & 16,94 & 17,45 & 16,54 & 16,15 & 16,00 \\
\hline \multicolumn{2}{|c|}{ Diâmetro da Área Irrigada } & \multicolumn{5}{|c|}{ Altura da planta (cm) } \\
\hline & & \multicolumn{4}{|c|}{ Sem cobertura do solo } & \\
\hline $0,7 \mathrm{~m}$ & & 114,06 & 115,78 & 117,51 & 118,59 & 118,59 \\
\hline $0,8 \mathrm{~m}$ & & 133,40 & 135,49 & 139,48 & 140,42 & 140,42 \\
\hline $0,9 \mathrm{~m}$ & & 113,85 & 118,37 & 122,32 & 122,99 & 122,99 \\
\hline $1,0 \mathrm{~m}_{4}$ & & 87,61 & 91,58 & 96,04 & 97,81 & 97,81 \\
\hline \multirow[t]{2}{*}{ DMS } & & 3,53 & 3.40 & 3,27 & 3,23 & 3,23 \\
\hline & \multicolumn{5}{|c|}{ Com cobertura do solo } & \\
\hline $0,7 \mathrm{~m}$ & & 112,70 & 117,60 & 122,67 & 123,57 & 123,97 \\
\hline $0,8 \mathrm{~m}$ & & 120,33 & 122,50 & 123,67 & 124,50 & 125,33 \\
\hline $0,9 \mathrm{~m}$ & & 133,30 & 136,63 & 137,67 & 138,97 & 140,27 \\
\hline $1,0 \mathrm{~m}$ & & 112,43 & 118,20 & 119,17 & 120,53 & 121,70 \\
\hline DMS & & 41,65 & 54,07 & 53,58 & 51,83 & 52,83 \\
\hline
\end{tabular}

${ }^{\mathrm{ns}}$ não significativo. DAT - Dias após transplantio.

Observa-se que não houve diferença significativa na altura das plantas de coqueiro em nenhuma fase do crescimento do coqueiro para os diferentes diâmetros de área irrigada e tipos de cobertura do solo. Os coeficientes de variação ao redor de $16 \%$ permitem inferir uma boa exatidão do experimento. Assim, qualquer que seja o volume de água aplicado ou o tipo de cobertura do solo, a altura das plantas não foi afetada.

Assim como para a altura de planta, a análise de variância (Tabela 2) revelou que não houve diferença significativa tampouco para o diâmetro do caule das plantas de coqueiro para os diâmetros e tipos de condição de cobertura do solo. Considerando-se que um coeficiente de variação entre 12 e 15\% é classificado por Gomes (1970) como bom, isso indica que o delineamento estatístico utilizado exerceu bom controle sobre as variações do acaso. Assim, qualquer que seja o volume de água aplicada ou o tipo de cobertura do solo o diâmetro do caule das plantas não muda significativamente. 
SANTOS, I. S.; AZEVEDO, C. A. V.; GUERRA, H. O. C.; SOARES, F. A. L.; LIMA, V. L. A.; NETO, J. D. Economia de água na irrigação do coqueiro em função de áreas de maior concentração do sistema radicular e cobertura do solo. Ambi-Agua, Taubaté, v. 3, n. 3, p. 105-113, 2008. (doi:10.4136/ambi-agua.65)

Tabela 2. Resumo da análise de variância para o diâmetro do caule do coqueiro para os diferentes diâmetros da área irrigada e sob diferentes coberturas de solo.

\begin{tabular}{lcccccc}
\hline \multirow{2}{*}{ Causas de Variação } & \multirow{2}{*}{ GL } & \multicolumn{5}{c}{ Quadrados médios } \\
\cline { 3 - 7 } & 3 & $36,25^{\mathrm{ns}}$ & $6,81^{\mathrm{ns}}$ & $21,67^{\mathrm{ns}}$ & $9,81^{\mathrm{ns}}$ & $4,50^{\mathrm{ns}}$ \\
\hline Diâmetro (D) & 1 & $11,34^{\mathrm{ns}}$ & $0,01^{\mathrm{ns}}$ & $0,17^{\mathrm{ns}}$ & $3,38^{\mathrm{ns}}$ & $66,67^{\mathrm{ns}}$ \\
Condições de Solo (CS) & 3 & $25,12^{\mathrm{ns}}$ & $42,62^{\mathrm{ns}}$ & $41,25^{\mathrm{ns}}$ & $19,68^{\mathrm{ns}}$ & $57,00^{\mathrm{ns}}$ \\
Interação D x CS & 1 & $0,14^{\mathrm{ns}}$ & $5,57^{\mathrm{ns}}$ & $0,17^{\mathrm{ns}}$ & $3,63^{\mathrm{ns}}$ & $0,02^{\mathrm{ns}}$ \\
Testemunha x Fatorial & 2 & $17,29^{\mathrm{ns}}$ & $63,18^{\mathrm{ns}}$ & $8,07^{\mathrm{ns}}$ & $22,50^{\mathrm{ns}}$ & $25,59^{\mathrm{ns}}$ \\
Blocos & 16 & 12,83 & 10,59 & 17,42 & 21,38 & 26,30 \\
Resíduo & & 16,61 & 12,96 & 15,11 & 14,62 & 14,35 \\
\hline CV (\%) & & & & & & \\
\hline
\end{tabular}

\begin{tabular}{cccccc}
\hline Diâmetro da área irrigada & \multicolumn{5}{c}{ Diâmetro do caule (mm) } \\
\hline & \multicolumn{5}{c}{ Sem cobertura do solo } \\
\hline $0,7 \mathrm{~m}$ & 16,37 & 21,20 & 22,29 & 29,00 & 33,00 \\
$0,8 \mathrm{~m}$ & 22,17 & 28,00 & 29,48 & 32,67 & 41,33 \\
$0,9 \mathrm{~m}$ & 20,93 & 24,23 & 27,35 & 33,50 & 39,00 \\
$1,0 \mathrm{~m}$ & 23,93 & 27,67 & 30,47 & 32,33 & 36,33 \\
\hline & \multicolumn{5}{c}{ Com cobertura do solo } \\
\hline $0,7 \mathrm{~m}$ & 20,00 & 26,33 & 27,83 & 32,67 & 36,00 \\
$0,8 \mathrm{~m}$ & 20,67 & 23,00 & 25,00 & 27,50 & 30,33 \\
$0,9 \mathrm{~m}$ & 26,90 & 28,30 & 31,27 & 32,33 & 33,67 \\
$1,0 \mathrm{~m}$ & 21,33 & 23,50 & 26,83 & 32,00 & 36,17 \\
\hline
\end{tabular}

${ }^{\mathrm{ns}}$ não significativo. DAT - Dias após transplantio.

Na Tabela 3, são apresentados os volumes totais de água aplicados ao coqueiro durante os primeiros 120 dias após o transplantio.

Tabela 3. Volumes totais de água aplicados nos diferentes tratamentos e na testemunha durante os 120 dias após transplantio.

\begin{tabular}{ccc}
\hline TRATAMENTO & \multicolumn{1}{c}{ VOLUME DE ÁGUA APLICADO (L) } \\
\hline Diâmetro da área irrigada & Sem cobertura & Com cobertura \\
\hline $0,7 \mathrm{~m}$ & 310 & 154 \\
$0,8 \mathrm{~m}$ & 406 & 202 \\
$0,9 \mathrm{~m}$ & 513 & 256 \\
$1,0 \mathrm{~m}$ & 633 & 316 \\
Testemunha & 5120 & - \\
\hline
\end{tabular}

Obviamente, à medida que aumenta o diâmetro da área irrigada, aumenta o volume de água aplicada. A Tabela 3 mostra também que o solo sem cobertura recebeu o dobro de água que o solo com cobertura. Isso devido à freqüência de irrigação do solo sem cobertura que foi o dobro da freqüência do solo com cobertura.

A Tabela 4 apresenta os percentuais de economia no volume total de água aplicada promovidos pelos tratamentos para as diferentes condições de cobertura de solo e diâmetros da área irrigada em relação à testemunha. 
SANTOS, I. S.; AZEVEDO, C. A. V.; GUERRA, H. O. C.; SOARES, F. A. L.; LIMA, V. L. A.; NETO, J. D. Economia de água na irrigação do coqueiro em função de áreas de maior concentração do sistema radicular e cobertura do solo. Ambi-Agua, Taubaté, v. 3, n. 3, p. 105-113, 2008. (doi:10.4136/ambi-agua.65)

Tabela 4. Percentuais de economia no volume total de água aplicado.

\begin{tabular}{|c|c|c|c|c|c|c|}
\hline \multirow{2}{*}{$\begin{array}{l}\text { Diâmetro } \\
\text { molhado }\end{array}$} & \multirow{2}{*}{$\begin{array}{l}\text { Volume total } \\
\text { de água } \\
\text { aplicado (L) }\end{array}$} & \multicolumn{5}{|c|}{ Economia de Água (\%) } \\
\hline & & Trat. $^{1}$ & $\mathrm{SCC}^{2}$ & $\mathbf{D}_{1}{ }^{3}$ & $\mathbf{D}_{2}{ }^{4}$ & $\mathbf{D}_{3}{ }^{5}$ \\
\hline \multicolumn{7}{|c|}{ Sem cobertura do solo } \\
\hline $0,7 \mathrm{~m}$ & 310,01 & 93,95 & & & & \\
\hline $0,8 \mathrm{~m}$ & 405,70 & 92,08 & & 23,57 & & \\
\hline $0,9 \mathrm{~m}$ & 513,49 & 89,97 & & 39,63 & 20,990 & \\
\hline $1,0 \mathrm{~m}$ & 633,87 & 87,62 & & 51,09 & 36,00 & 18,99 \\
\hline \multicolumn{7}{|c|}{ Com cobertura do solo } \\
\hline $0,7 \mathrm{~m}$ & 154,60 & 96,98 & 50,13 & & & \\
\hline $0,8 \mathrm{~m}$ & 202,84 & 96,04 & 50,00 & 23,78 & & \\
\hline $0,9 \mathrm{~m}$ & 256,74 & 94,99 & 50,00 & 39,78 & 20,99 & \\
\hline $1,0 \mathrm{~m}$ & 316,93 & 93,81 & 50,00 & 51,22 & 36,00 & 18,99 \\
\hline
\end{tabular}

${ }^{1}$ Economia de água promovida pelo tratamento, em relação à testemunha.

${ }^{2}$ Economia de água com cobertura de solo. Economia de água usando: ${ }^{3} \mathrm{D}_{1},{ }^{4} \mathrm{D}_{2},{ }^{5} \mathrm{D}_{3}$, em relação aos diâmetros subseqüentes. SCC - solo com cobertura.

Na condição de solo sem cobertura, a máxima e a mínima economia de água foram, respectivamente, de 93,95\%, para o diâmetro de 0,7 m, e de $87,62 \%$, para o diâmetro de 1,0m. Para a condição de solo coberto, esses valores foram 96,98 e 93,81\%, respectivamente para os diâmetros de 0,7 e 1,0 m. Assim, conclui-se que o uso da menor área irrigada e, conseqüentemente, o menor volume de água produz a mesma altura de planta e diâmetro do caule que quando utilizada a maior área e com o maior volume. Isso se deve a que, embora o volume de água aplicado variasse, a lâmina de água se manteve sempre a mesma, pois foi calculada utilizando-se à evaporação do tanque Classe $\mathrm{A}$ em $\mathrm{mm}$, igual para todos os diâmetros.

Em termos relativos, os diâmetros molhados de 0,7; 0.8 e 0,9 m promoveram praticamente as mesmas economias de água nas condições de solo sem e com cobertura, que foram, respectivamente, em torno de 23 a 51\%, de 20 a 36\%, e de 18\%. Considerando-se que os diferentes volumes de água aplicada não produziram nenhuma variação significante nas variáveis de crescimento do coqueiro estudadas, recomenda-se a utilização do menor diâmetro de área irrigada a qual significará uma importante economia de água.

A irrigação a cada dois dias conduzida para o solo com cobertura originou uma economia de água de 50\%, com uma média diária para o volume de água aplicado, referente aos primeiros 120 dias após o transplantio, que variou de 1,29 a 2,64 L nos diferentes tratamentos; enquanto que para as condições de solo sem cobertura essa média variou de 2,58 a 5,28 L e para a testemunha foi de 42,67 L. Dessa forma, a cobertura da superfície do solo com o plástico de polietileno de dupla face efetivamente contribuiu, como esperado, para uma redução substancial no volume de água aplicado para atender às necessidades hídricas da cultura do coqueiro, tornando quase que todo o volume de água aplicado disponível à cultura. Esse fato mostra, então, a importância de se controlar a temperatura do solo em regiões semiáridas, evidenciando também a eficiência do filme de polietileno de duas faces (preta e branca) para essa finalidade, o qual cobriu a superfície do solo de forma que a parte branca ficou virada para cima para refletir a luz do sol, amenizando, assim, a alta temperatura no solo, e a parte de cor preta ficou virada para baixo para que o calor naquela região fosse absorvido. 


\section{CONCLUSÕES}

Os resultados obtidos permitem concluir:

1. O uso das áreas de maior concentração de raízes para o cálculo do volume de água a ser aplicado na cultura do coqueiro promoveu uma considerável economia de água, em relação ao procedimento tradicionalmente utilizado.

2. A cobertura da superfície do solo contribuiu para uma redução substancial do volume de água utilizado pelo coqueiro.

\section{REFERÊNCIAS}

AGRIANUAL. Anuário da agricultura brasileira. São Paulo: FNP, 2000. p.330-339.

EMPRESA BRASILEIRA DE PESQUISA AGROPECUÁRIA - EMBRAPA. Centro Nacional de Pesquisa de Solos. Sistema brasileiro de classificação de solos. Rio de Janeiro: Embrapa Solos, 1999. 412 p.

CERMEÑO, Z. S. Estufas: instalações e manejo. Lisboa: Litexa, 1990. 355p.

EMPRESA PERNAMBUCANA DE PESQUISA AGROPECUÁRIA - IPA. Recomendações de adubação para o Estado de Pernambuco. Recife: IPA, 1998. 198 p.

FERREIRA, P. V. Estatística experimental aplicada à agronomia. Maceió: UFAL/EDUFAL/FUNDEPES, 1991. 437 p.

FERREIRA, J. M. S.; WARWIK, D. R. N.; SIQUEIRA, L. A. A cultura do coqueiro no Brasil. Aracaju: Embrapa CPATC, 1997. 292 p.

GOMES, F. P. Curso de estatística experimental. Piracicaba: ESALQ-USP, 1970. 430p.

GOTO, R. Plasticultura nos trópicos: uma avaliação técnico-econômica. Horticultura brasileira, v. 15, p. 163-165, 1997.

HOWELL, T. A.; HILLER, E. A. Trickler Irrigation System Design. St. Joseph: ASAE, 1972. $221 \mathrm{p}$.

INSTITUTO BRASILEIRO DE GEOGRAFIA E ESTATÍSTICA - IBGE. SIDRA. Banco de Dados Agregados, Produção Agrícola Municipal. 2006. Disponível em: $<$ http://www.ibge.gov.br/bda/tabela/listabl.asp?c=1613\&z=t\&o= 11>. Acesso em: 22 agosto 2006.

MIRANDA, F. R.; OLIVEIRA, V. H.; MONTENEGRO, A. A. T. Desenvolvimento e precocidade de produção do coqueiro Anão (Cocos nucifera L.) sob diferentes regimes de irrigação. Agrotopica, v. 11, n. 2, p. 26-31, 1999.

NOGUEIRA, L. C; NOGUEIRA, L. R. Q.; MIRANDA, F. R. Irrigação do coqueiro. In: A cultura do coqueiro no Brasil. Aracaju: Embrapa CPATC, 1997. p. 159-187.

PINTO, J. P. Efeito do tipo de cobertura de polietileno preto na evapotranspiração e na produção da cultura de alface. Viçosa, 1997. 55p. Dissertação (M.S.) - Universidade Federal de Viçosa. 
SANTOS, I. S.; AZEVEDO, C. A. V.; GUERRA, H. O. C.; SOARES, F. A. L.; LIMA, V. L. A.; NETO, J. D. Economia de água na irrigação do coqueiro em função de áreas de maior concentração do sistema radicular e cobertura do solo. Ambi-Agua, Taubaté, v. 3, n. 3, p. 105-113, 2008. (doi:10.4136/ambi-agua.65)

SANTOS, J. W. dos; MOREIRA, J. de A. N.; BELTRÃO, N. E. M. Avaliação do emprego dos testes de comparação de médias na revista Pesquisa Agropecuária Brasileira de 1980 a 1994. Pesquisa Agropecuária Brasileira, v. 33, n. 3, p. 225-230, 1998.

SGANZERLA, E. Nova agricultura: a fascinante arte de cultivar com os plásticos. Porto Alegre: Plasticultura Gaúcha, 1991. 303 p.

THAMPAN, P. K. Success story in drip irrigation. Indian Coconut Journal, v. 21, n. 9, p. 810, 1991. 


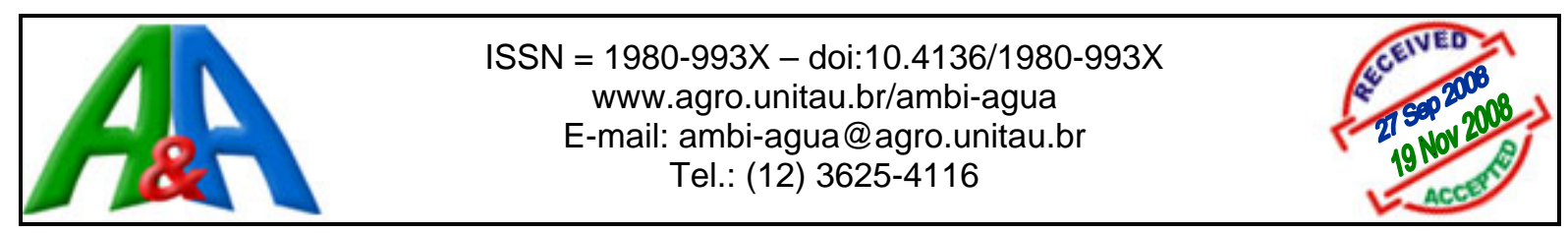

\title{
Avaliação da qualidade da água dos mananciais na ilha de Fernando de Noronha
}

(doi:10.4136/ambi-agua.66)

\author{
Maurício da Motta ${ }^{1}$; Valdinete L. Silva ${ }^{1}$; Abelardo A. A. Montenegro ${ }^{2}$; Suzana \\ M. G. L. Montenegro ${ }^{3}$; Marcus M. Correa ${ }^{2}$ \\ ${ }^{1}$ Departamento de Engenharia Química - Universidade Federal de Pernambuco, R. Prof. Arthur de Sá, s/n \\ Cidade Universitária - CEP: 50740-521 - Recife - PE - Brasil \\ E-mail: \{mottas, vlins\}@ufpe.br \\ ${ }^{2}$ Departamento de Tecnologia Rural, UFRPE \\ E-mail: monte@hotlink.com.br; metri@ufrpe.br \\ ${ }^{3}$ Departamento de Engenharia Civil, UFPE \\ E-mail: suzanam@ufpe.br
}

\section{RESUMO}

O arquipélago de Fernando de Noronha é formado por 21 ilhas. A maior delas é abastecida por dois açudes, uma placa coletora de água da chuva e um sistema de dessalinização de água do mar. Além desses reservatórios e sistemas auxiliares, a ilha conta ainda com outros 6 açudes e alguns poços. Todavia, durante o período de estiagem, a ilha sofre escassez de água, que compromete inclusive a capacidade turística, maior fonte de renda local. Dentro desse escopo buscou-se avaliar a qualidade de água de diversos mananciais, para utilização no abastecimento. Foram realizadas medidas "in loco" e análises físicoquímicas em laboratório. Concluiu-se que se faz necessária uma re-estruturação do sistema de abastecimento da ilha para evitar novos problemas de racionamento e risco de colapso.

Palavras-chave: monitoramento; qualidade da água; eutrofização.

\section{Water Quality Evaluation of the Springs in Fernando de Noronha Island}

\begin{abstract}
The Fernando de Noronha archipelago is composed by 21 islands. The biggest of them, the Fernando de Noronha island, is supplied in domestic water by two reservoirs, one rainwater collecting system and another system using sea water desalinization. In addition, this island is supplied by water from six secondary artificial ponds and some wells and springs. However, during the summer drought time, the island endures a water supply reduction that endangers the touristic activities, which are the main economical local financial source. In this concern, were evaluated the quality of the water from several sources for human supplying. Some measurements were performed "in site" and laboratory physical chemical analyses as well. It could be concluded that a further reorganization of the water supply system ought to be carried out in order to avoid future problems and risk of water supply collapse in this island.
\end{abstract}

Keywords: monitoring; water quality; eutrofization. 


\section{INTRODUÇÃO}

O Arquipélago de Fernando de Noronha localiza-se nas coordenadas $3^{\circ} 54^{\prime} \mathrm{S}$ de latitude e $32^{\circ} 25^{\prime} \mathrm{W}$ de longitude a $545 \mathrm{~km}$ de Recife, capital do estado de Pernambuco, e a $360 \mathrm{~km}$ de Natal, capital do estado do Rio Grande do Norte; formado pelo topo das montanhas de uma cordilheira de origem vulcânica, sua base se localiza a cerca de $4.000 \mathrm{~m}$ de profundidade, a Dorsa Mediana do Atlântico, e é constituído por 21 ilhas, rochedos e ilhotas, no total aproximado de $26 \mathrm{~km}^{2}$, tendo a ilha principal $17 \mathrm{~km}^{2}$ de área. A ilha se compõe de dois tipos de rocha, vulcânica e sedimentar, que se dividem nas formações Remédios, Quixaba e São José, em que os solos são desenvolvidos de tufos da formação Remédios (Rocha et al., 2005).

Fernando de Noronha é a ilha principal do arquipélago e a única habitada. Mais de três mil pessoas vivem nessa ilha remanescente dos diversos regimes implantados no arquipélago. São descendentes de prisioneiros, de militares, de pessoas que vieram a prestar serviços que ali permaneceram ou turistas atraídos pelo arquipélago e que nele passaram a viver.

O Arquipélago de Fernando de Noronha é constituído por duas Unidades de Conservação Federais do Instituto Brasileiro do Meio Ambiente e dos Recursos Naturais Renováveis (IBAMA): Área de Proteção Ambiental de Fernando de Noronha (APA-FN) e Parque Nacional Marinho de Fernando de Noronha (Parnamar-FN). O Parnamar-FN compreende aproximadamente 50\% da área da Ilha Fernando de Noronha, todas as demais 17 ilhas secundárias do Arquipélago e a maior parte das águas adjacentes até a profundidade de 50 metros, totalizando uma área de $112,7 \mathrm{~km}^{2}$. Na APA-FN está localizada toda a ocupação permanente de moradia, agropecuária, indústria hoteleira, prestação de serviço e instalações de infra-estrutura (Silva Jr., 2003).

Em 1992, primeiro ano em que o Departamento de Controle Migratório da Administração do Distrito Estadual de Fernando de Noronha obteve dados precisos da entrada de visitantes na ilha, 10.094 turistas foram contabilizados. Ao longo do ano de 2002, a ilha recebeu 62.551 visitantes, um aumento de 520\% em 10 anos. De 1988 a 2002, a população residente da Ilha (permanente e temporária) passou de 1.500 para 3.200, devido à imigração de pessoas que vieram ocupar os postos de serviços criados pelo turismo. A população incidente máxima (moradores permanentes, moradores temporários e visitantes que ocupam simultaneamente a ilha) passou de 1.600, em 1988, para 4.200 pessoas em 2002. Em junho de 2003, o Arquipélago contava com quatro hotéis e 108 hospedarias domiciliares, com capacidade total de 1260 leitos (Silva Jr., 2003).

Devido à privilegiada localização do arquipélago, o clima reinante é o tropical semiúmido de tendência a semi-árido, com baixa pluviosidade média anual $\left(1.200 \mathrm{~mm} / \mathrm{m}^{2}\right)$. O mês de julho é o mais frio (Barros, 1959). Está sob o domínio dos ventos alísios de sudeste. A temperatura média anual é de $27^{\circ} \mathrm{C}$.

Pode ser observado, pela Figura 1, que o comportamento das chuvas permanece o mesmo da média histórica, apesar de apresentar valores bem mais baixos para o ano de 2005 . Segundo Carvalho (1999), o período que vai do fim do mês de fevereiro até o fim do mês de agosto é conhecido como inverno, responsável pelos maiores índices de precipitação pluviométrica na ilha. Do inverno depende o nível de reserva dos açudes e, conseqüentemente, o abastecimento de água do arquipélago. 


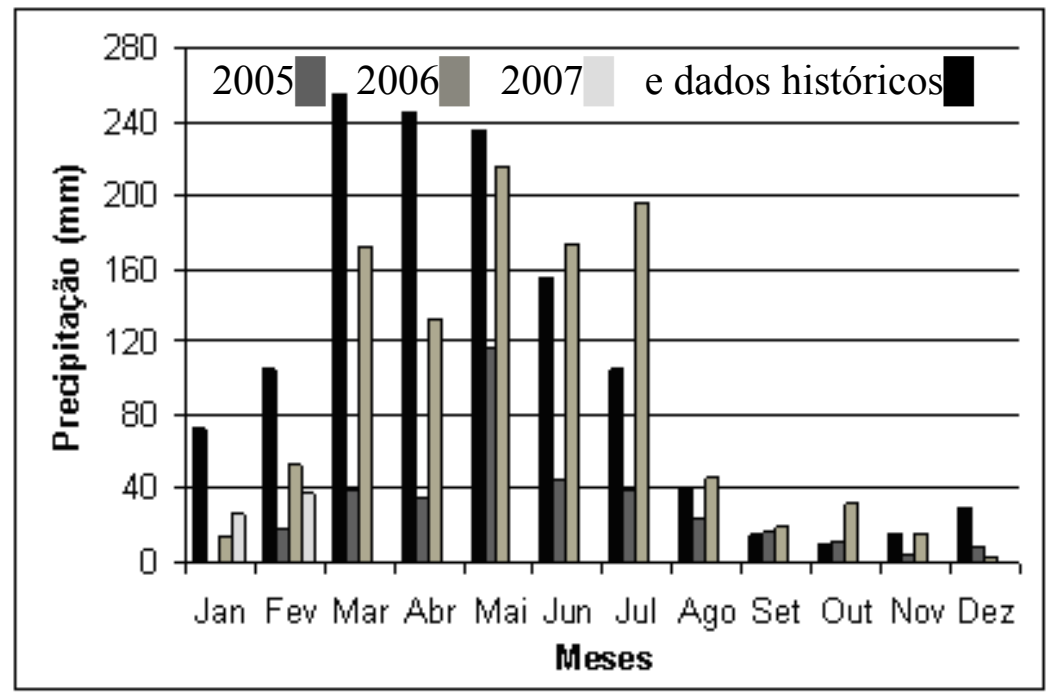

Figura 1. Dados de precipitação na ilha de Fernando de Noronha para os anos de 2005, 2006 e 2007 e dados históricos (Carvalho, 1999) para o período de 1976 a 1997.

Para o fornecimento de água potável, a Companhia Pernambucana de Águas e Esgoto (COMPESA), utiliza o açude do Xaréu como ponto de captação. Esse açude, que tem uma capacidade máxima de armazenamento de $200.000 \mathrm{~m}^{3}$, quando abastecido tem uma produção de 4,2 L/s (aproximadamente $362 \mathrm{~m}^{3} / \mathrm{dia}$ ) (Carvalho, 1999). Ele está atualmente sendo dragado e os aguapés da superfície estão sendo retirados, ampliando a capacidade de armazenamento para $300.000 \mathrm{~m}^{3}$. O açude da Pedreira, que também é utilizado em pequena escala no abastecimento da ilha, tem uma capacidade de $24.000 \mathrm{~m}^{3}$ (Carvalho, 1999). Além desses dois açudes, a ilha dispõe ainda de 6 outros, que são utilizados na dessedentação de animais e na irrigação, encontrando-se atualmente dois deles completamente assoreados (Boldró e Borges). A Figura 2 mostra a localização de alguns desses açudes. Além destes açudes, a ilha conta ainda com uma placa coletora de água da chuva e com um sistema de dessalinização que fornece $36 \mathrm{~m}^{3} / \mathrm{h}$, durante 20 horas por dia. Esse sistema de dessalinização passou por uma série de ampliações desde a sua implantação no ano 2000, alcançando a produção atual em fevereiro de 2006 (COMPESA, 2007). Além desses mananciais, a ilha dispõe de 44 poços, sendo 4 utilizados pela companhia de abastecimento, dos quais destacamse: o do QG, que está acoplado a um sistema de dessalinização, fornecendo água em garrafões de 20 litros; o da Vila da Aeronáutica e o da Caieira utilizados para distribuição de água em carros-pipa. Esses últimos apresentam contaminação por coliformes, segundo Da Motta e Pereira (2006) e Da Motta (2005).

Apesar desses reservatórios e sistemas auxiliares, a ilha sofre falta de água, comprometendo inclusive a sua capacidade turística, que é a sua maior fonte de renda. Dentro desse escopo, buscou-se avaliar a qualidade de água de outros mananciais, para sua posterior utilização no abastecimento, assim como aumentar a capacidade de armazenamento de água da ilha. Neste trabalho serão apresentados os resultados do monitoramento e da avaliação. 


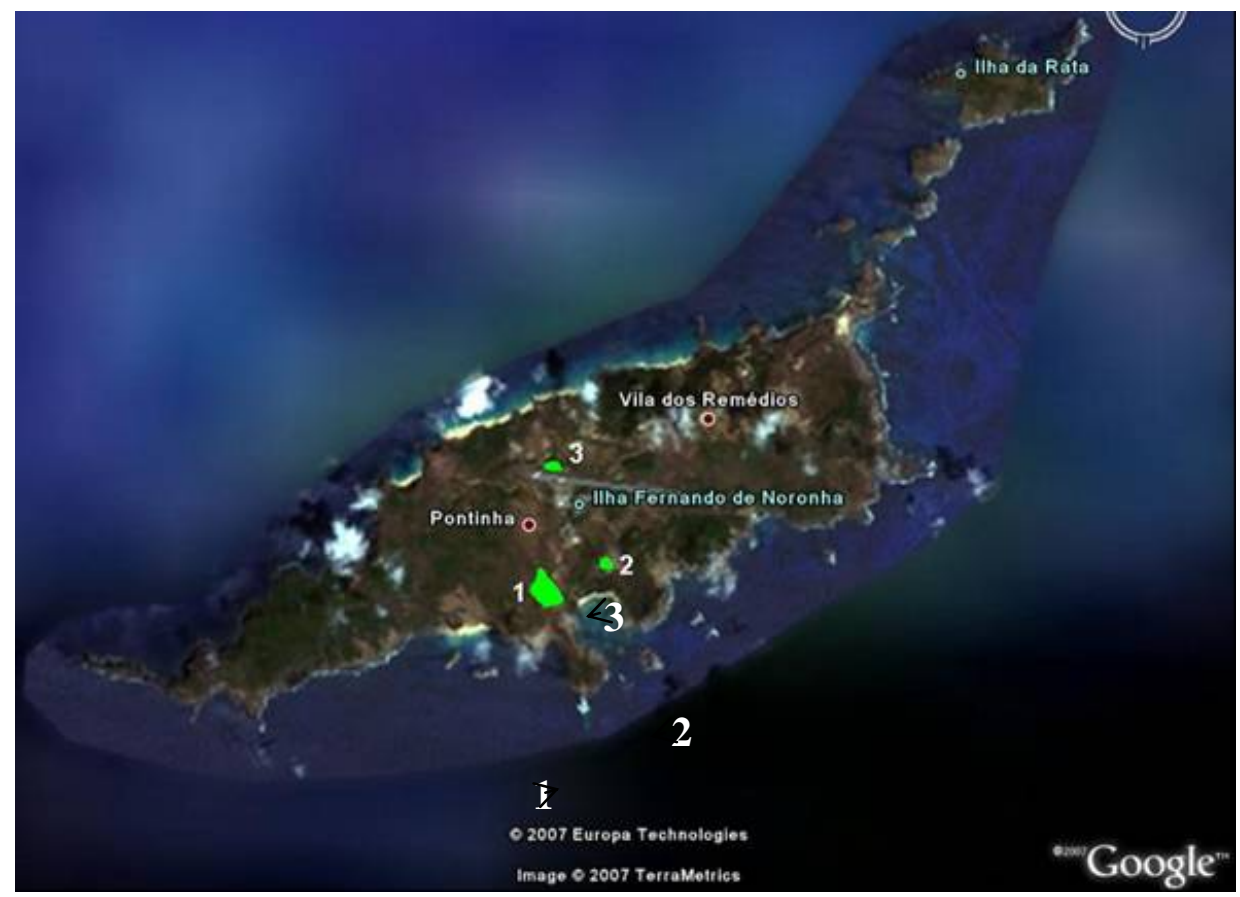

Figura 2. Localização dos açudes Xaréu (1), Pedreira (2) e Emas (3) na ilha de Fernando de Noronha.

\section{MATERIAIS E MÉTODOS}

Para a avaliação da qualidade dos mananciais, tanto no que diz respeito a viabilidade da sua utilização como na qualidade da água foram realizadas observações e análises químicas das águas "in situ" e no laboratório. No primeiro caso, além de avaliar os mananciais como fonte de recursos hídricos foram analisados a concentração de oxigênio dissolvido, condutividade elétrica, temperatura da água e teor de sólidos totais dissolvidos. Para a realização das análises físico-químicas e microbiológicas no laboratório, foram feitas coletas em pontos determinados e as amostras preservadas e acondicionadas em caixas térmicas e transportadas no mesmo dia até o local das análises. Foram realizadas as seguintes determinações, seguindo-se a metodologia do Standard Methods for the Examination of Water and Wastewater (APHA, 1995): pH através de pHmêtro Digimed modelo TM-20; demanda química de oxigênio (DQO) (Método $5220 \mathrm{C}$ ); demanda bioquímica de oxigênio $\left(\mathrm{DBO}_{5}\right.$ ) (Método 5210B); sólidos totais (ST) (Método $2540 \mathrm{~B}$ ); sólidos Fixos (SF) e sólidos voláteis (SV) (Método $2540 \mathrm{E}$ ); fósforo - $\mathrm{P}$ (Método 4500-P C), nitrogênio amoniacal $\left(\mathrm{NNH}_{3}\right.$ ) (Método 4500- $\mathrm{NH}_{3} \mathrm{C}$ ); nitrogênio total- NT (Método 4500-N C); cloretos (Método $4500 \mathrm{Cl}^{-} \mathrm{B}$ ); salinidade medida através de condutivímetro Schott modelo handylab LF1 e a concentração de oxigênio dissolvido foi determinada por meio de um oxímetro Schott, modelo handylab OX1.

Foram realizadas coletas desses mananciais nos meses de julho, setembro e novembro de 2004 e em fevereiro, maio, agosto e outubro de 2005. Serão apresentados os resultados da avaliação e monitoramento de três açudes da ilha de Fernando de Noronha, sendo dois deles utilizados para o abastecimento de água potável da ilha (Xaréu e Pedreira) e um para a irrigação (Emas). Diante da problemática da escassez de água, gerada por um mau gerenciamento desse recurso na ilha, acentuada por uma escassez de chuva, avalia-se aqui também a possibilidade da utilização deste último para o abastecimento de água. 


\section{RESULTADOS E DISCUSSÃO}

Foi constatada, em vários reservatórios da ilha, a existência de uma espécie de aguapé conhecido como Alface d'água (Pistia stratiotes). A aguapé deteriora a qualidade da água, aumenta as perdas de água nos reservatórios, devido à evapotranspiração, e pode ainda favorecer a disseminação de doenças. O Pistia stratiotes (Figura 3), também é conhecido como pasta, alface d'água, mururé, lentilha d'água, dentre outros nomes (PLANTAMED, 2005). No Brasil, no momento, não há nenhum herbicida registrado para controle de aguapé, e a maioria das pesquisas trabalha com herbicidas em condições controladas ou em pequenos corpos hídricos sem fluxo de água.
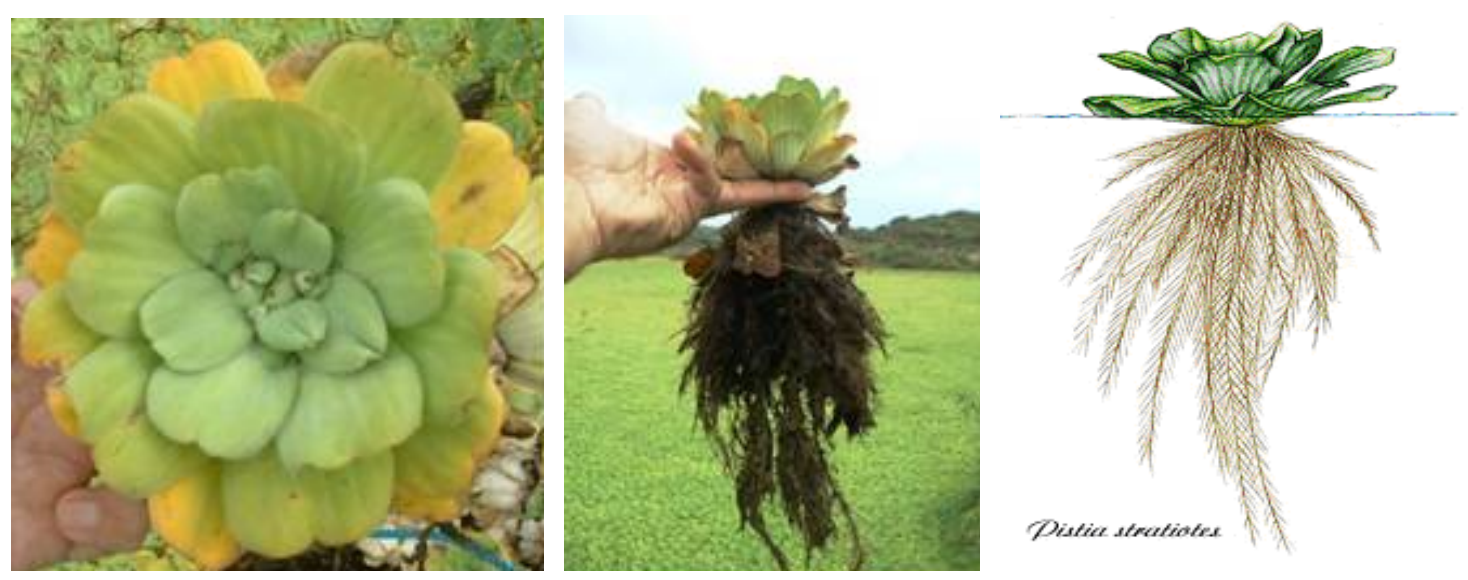

Figura 3. Fotos e figura do aguapé.

Fonte: Fotos dos autores e figura de PLANTAMED (2005).

As plantas de $P$. stratiotes são espécies cosmopolitas com ampla distribuição por todo o planeta (University of Florida, 2004 apud Carvalho et al., 2005). P. stratiotes é uma planta aquática perene, flutuante livre, nativa da América Tropical e que se propaga por estolões. Por ter sua água utilizada para o abastecimento, a utilização de herbicidas nesses reservatórios não seria indicada, podendo assim ser indicada a sua remoção e valoração. PLANTAMED (2005) cita, entre outras indicações das folhas desse aguapé, a sua utilização em casos de asma, diabete insípida, diarréia e enfermidades dos rins e da bexiga. Dessa forma, estaria se controlando o desenvolvimento desse aguapé e ofertando uma fonte de renda para a população local.

Com o aumento da população, principalmente em ambientes rurais, o fósforo que é um nutriente essencial para o cultivo de vegetais e criação de gado, quando exportado dessas áreas devido a enxurradas, pode atingir o ambiente aquático, promovendo dessa maneira o enriquecimento da água e desencadeando o processo de eutrofização (Sharpley et al., 1999). Uma vez que o fósforo é elemento chave para a eutrofização dos sistemas aquáticos, muita atenção deve ser dada a sua ciclagem entre o sedimento e a água intersticial, bem como à liberação do fósforo solúvel do sedimento para a coluna de água (Koski-Vahalae e Hartikainen, 2001). As reações de adsorção-dessorção parecem controlar as trocas de fósforo em solos minerais. A capacidade de adsorção dos sedimentos suspensos tem demonstrado ser mais alta do que as partículas da superfície do solo porque os processos erosivos seletivamente transportam partículas finas com alta capacidade de fósforo adsorvido (Sharpley, 1980).

O nitrogênio é o nutriente limitante para o crescimento da maioria das plantas em solos agrícolas. Assim, para o aumento da produção agrícola são utilizadas quantidades cada vez 
maiores de fertilizantes, que liberam grande quantidade de nitrogênio orgânico e inorgânico para o meio ambiente (Muchovej e Recgcigl, 1994). O uso excessivo de nitrogênio, além da capacidade de fixação pelas plantas, parece ser a principal fonte de nitrato tanto para a água superficial quanto para a água subterrânea em áreas agrícolas, principalmente nos locais onde a aplicação de fertilizantes com nitrogênio ou esterco ocorre antes de picos de chuva (Kirchmann, 1994). A concentração de nitrogênio na enxurrada, especialmente sob a forma de nitrato, está associada a diversos fatores, dentre eles a umidade anterior do solo, propriedades do solo, declividade e às práticas agrícolas como tipo de cultivo, época de aplicação e forma de incorporação ao solo (Owens, 1994).

\section{Açude Xaréu}

Por ser o principal fornecedor de água para a ilha, esse açude teve um acompanhamento mais intensivo e detalhado. Foi constatada aqui também a presença de aguapés Pistia stratiotes. Esses aguapés devem ser retirados para uma melhor oxigenação da água e minimização da evaporação (Pott e Pott, 2000). A limpeza das suas bordas e a colocação de uma cerca no seu entorno contribuiriam significativamente para a melhoria da qualidade da água, uma vez que reduziriam o contato dos animais, e seus resíduos, com a água do açude.

A Figura 4 apresenta a variação do nível do açude Xaréu no ano de 2004. Pode ser observado um decréscimo acentuado no volume desse corpo hídrico devido à reduzida pluviosidade e elevada isolação, que contribuem para uma alta taxa de evaporação e o crescimento dos aguapés, o que aumenta a perda de água pela evapotranspiração. No início de 2005 foi parado o monitoramento do nível desse açude por problemas nas réguas e o baixo nível que ele atingiu.

O nível desse açude chegou a seu mínimo para captação em fevereiro de 2006. Período em que todos os açudes da ilha atingiram seu nível mínimo. Após esse período, continuou-se a captação de água, mas apenas da água perdida que passa sob o paredão, que é captada através de um sistema de drenagem que encaminha essa água para um poço (Figura 5).

Em termos de monitoramento, verificou-se a necessidade de analisar um ponto na entrada de água do açude, para verificar a entrada de possíveis contaminantes, como resíduos de agrotóxicos ou fertilizantes. Estes podem causar a eutrofização do açude, o que explicaria a elevada concentração de aguapés que cobrem toda a sua superfície.

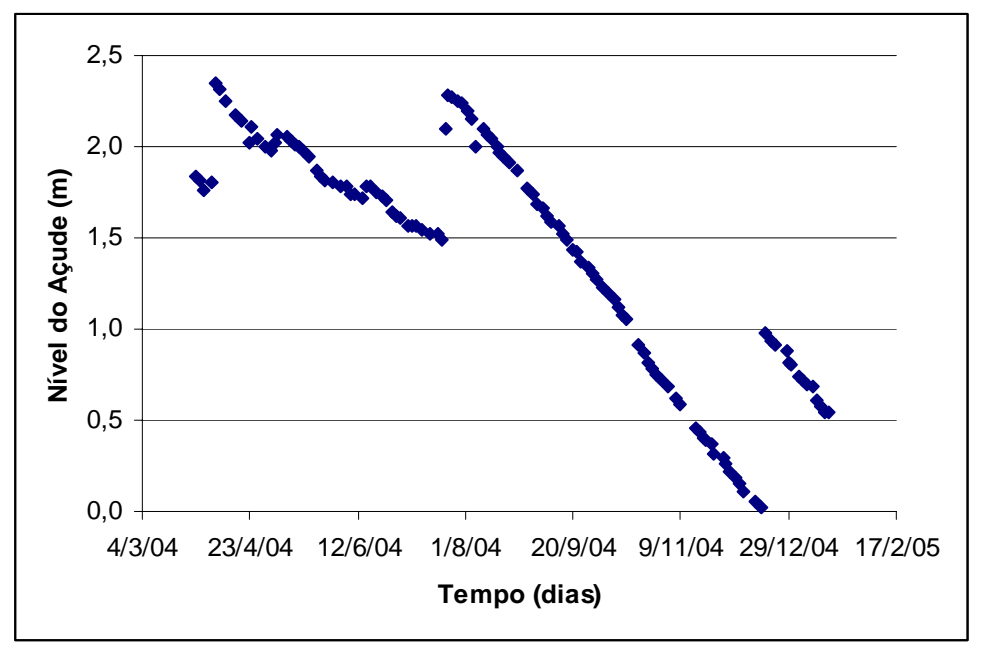

Figura 4 - Variação do nível do açude Xaréu. 


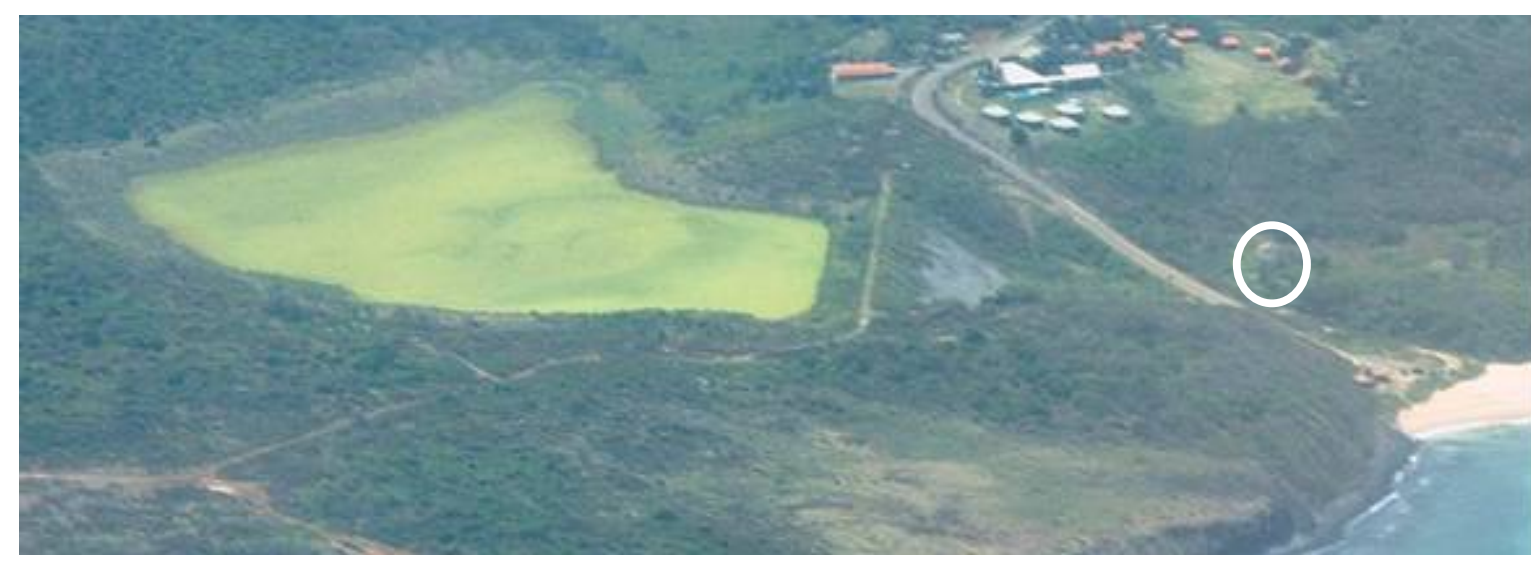

Figura 5. Vista do açude Xaréu em 22 de setembro de 2004. Detalhe para o ponto de captação de água de escoamento subterrâneo da barragem.

\section{Análises Físico-Químicas}

Pode ser observado na Figura 6a, que o teor de nitrogênio total apresentou um aumento de $43 \%$ durante o período de monitoramento, enquanto houve uma redução no teor de fósforo. Por outro lado, o teor de nitrogênio amoniacal apresentou uma ligeira queda.
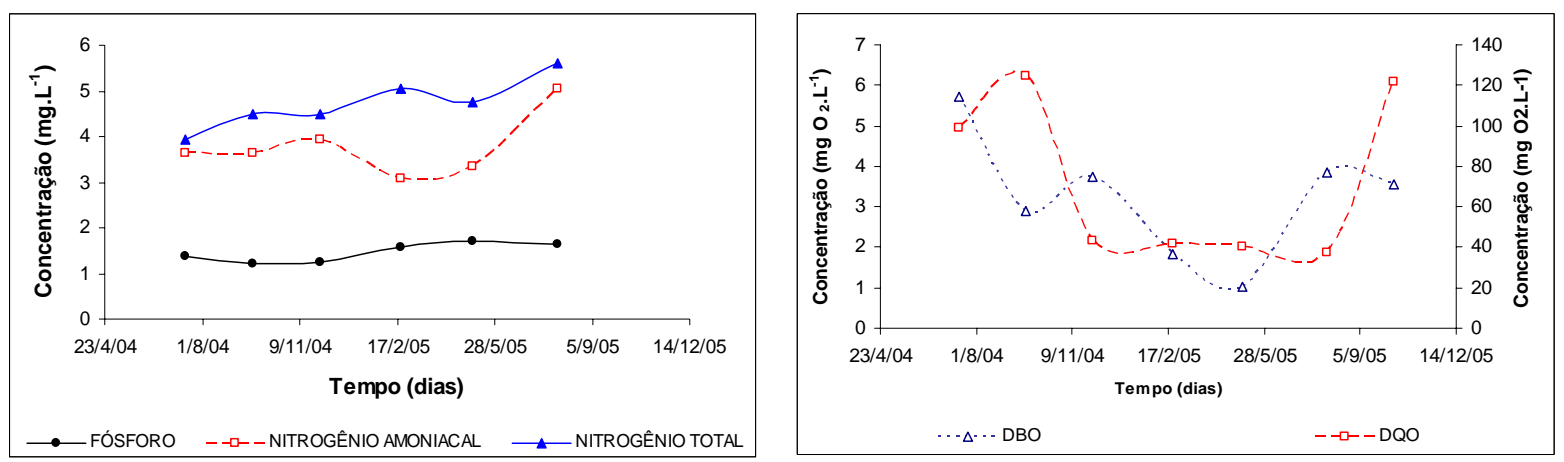

Figura 6. Variação da concentração dos nutrientes (a) e da DBO e DQO (b) da água do açude Xaréu em função do tempo.

A concentração de matéria orgânica biodegradável $\left(\mathrm{DBO}_{5}\right)$ apresentou uma redução de $82 \%$ até maio de 2005. Em seguida, após a limpeza do açude ocorreu um aumento desta. Verificou-se que a concentração de matéria orgânica (DQO) diminuiu cerca de $60 \%$ para o mesmo período, conforme pode ser visto na Figura 6 b, aumentando em outubro de 2005 . Essa redução no valor da matéria orgânica pode estar associada à diminuição no fluxo de entrada de água no reservatório, devido ao período da estiagem e à degradação realizada pelos microorganismos (bactérias) presentes no açude.

$\mathrm{O}$ aumento na concentração dos compostos nitrogenados deve ter ocorrido, provavelmente, pela redução do volume do açude. Outra possibilidade é a liberação pela decomposição das plantas, que pode ser verificada ao se comparar a evolução do nitrogênio amoniacal (Figura 6a) com a da DBO (Figura 6b). Em relação ao teor de fósforo, a sua concentração permanece estável.

O pH desse açude apresentou uma variação importante no dia 20/09/04, quando atingiu valores próximos a 3 (Figura 7a). Esse valor baixo pode ter sido um erro na análise, por problemas com o aparelho. Outra possibilidade seria o descarte de algum produto, hipótese descartada pela tipologia das propriedades localizadas próximas a esse corpo hídrico como aos seus contribuintes. A possibilidade de ter sido originado por reações biológicas 
anaeróbias também é eliminada por ter sido um valor muito baixo frente ao volume de água. Considerando-se apenas os pontos, o $\mathrm{pH}$ permaneceu em torno de 7, indicando a neutralidade da água. A condutividade elétrica apresentou valores crescentes, devido à evaporação da água e ao aumento do teor de sólidos e sais.

$\mathrm{O}$ aumento do teor de sólidos, observado pela condutividade, foi confirmado pelo aumento na concentração de sólidos totais (ST), apresentada na Figura 7b. O percentual de sólidos voláteis $(\% \mathrm{SV})$, que está associada à quantidade de matéria orgânica, apresentou inicialmente um aumento acompanhando os ST. A partir de maio de 2005, os valores voltaram a se estabilizar com valores em torno de $18 \%$.
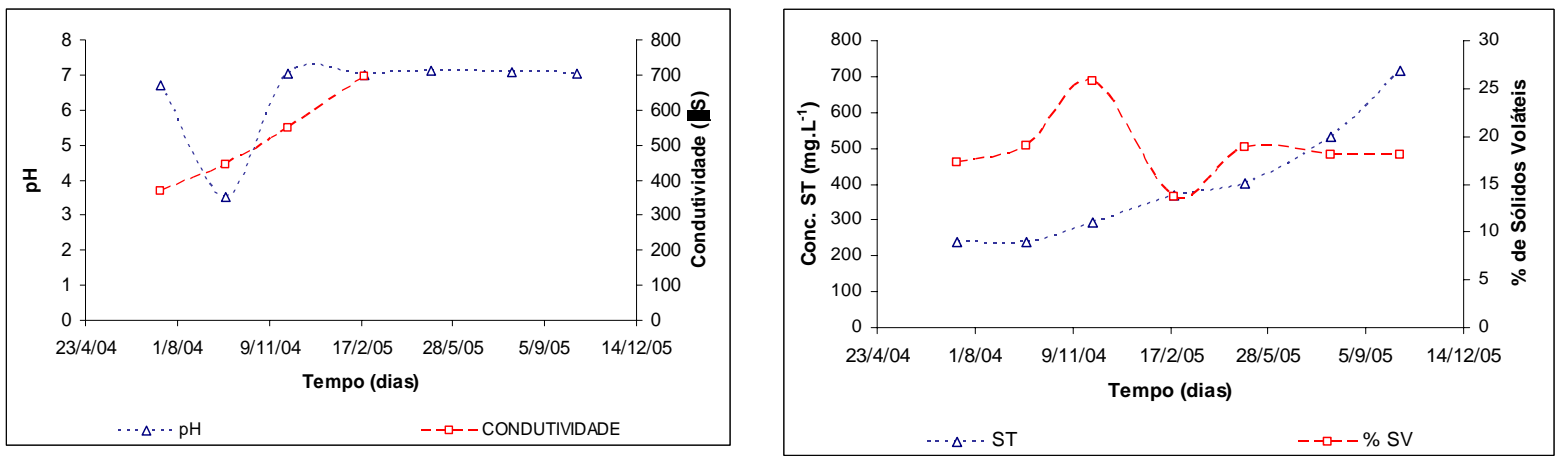

Figura 7. Variação do $\mathrm{pH}$ e da condutividade (a) e dos sólidos totais (ST) e porcentagem dos voláteis (b) em função do tempo para o açude Xaréu.

\section{Açude da Pedreira}

Esse açude funciona como sistema auxiliar para fornecimento de água para a ilha. Como pode ser observado pela Figura 8, ele se encontra com um nível muito baixo, não fornecendo mais água à ilha há vários meses. Como reservatório secundário, ele também precisa ser monitorado. No seu interior também foi constatada a presença da mesma espécie de aguapé encontrado no açude Xaréu. A limpeza do interior desse açude é necessária, possibilitando assim a remoção de vegetação, aguapés e animais mortos. Apenas em abril de 2005 foi instalada uma régua de medição do nível d'água para avaliação de sua capacidade, visando a uma melhor gestão do sistema.

Feitos esses serviços, deve-se partir para o aumento da captação de água para esse açude. A água da BR e a da pista do aeroporto pode ser enviada para este açude. Análises preliminares da qualidade dessas águas indicam a possibilidade da utilização delas para o abastecimento, após tratamento convencional.

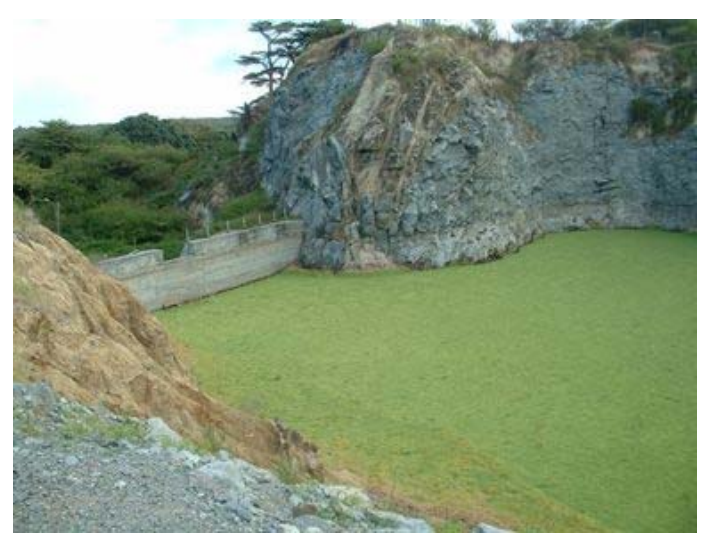

Figura 8. Vista do açude da Pedreira em Julho de 2004. 


\section{Análises Físico-Químicas}

Assim como para o açude Xaréu, foi observada também uma redução no teor de fósforo e uma ligeira queda no teor de nitrogênio amoniacal até fevereiro de 2005 e posterior aumento nos meses subseqüentes. O nitrogênio total apresentou-se relativamente estável (Figura 9a) até o mesmo mês citado e, a partir de então, começou a aumentar. As concentrações de matéria orgânica biodegradável e total apresentaram uma queda nas três primeiras análises e em seguida um aumento significativo, seguido de uma nova redução (Figura 9b).
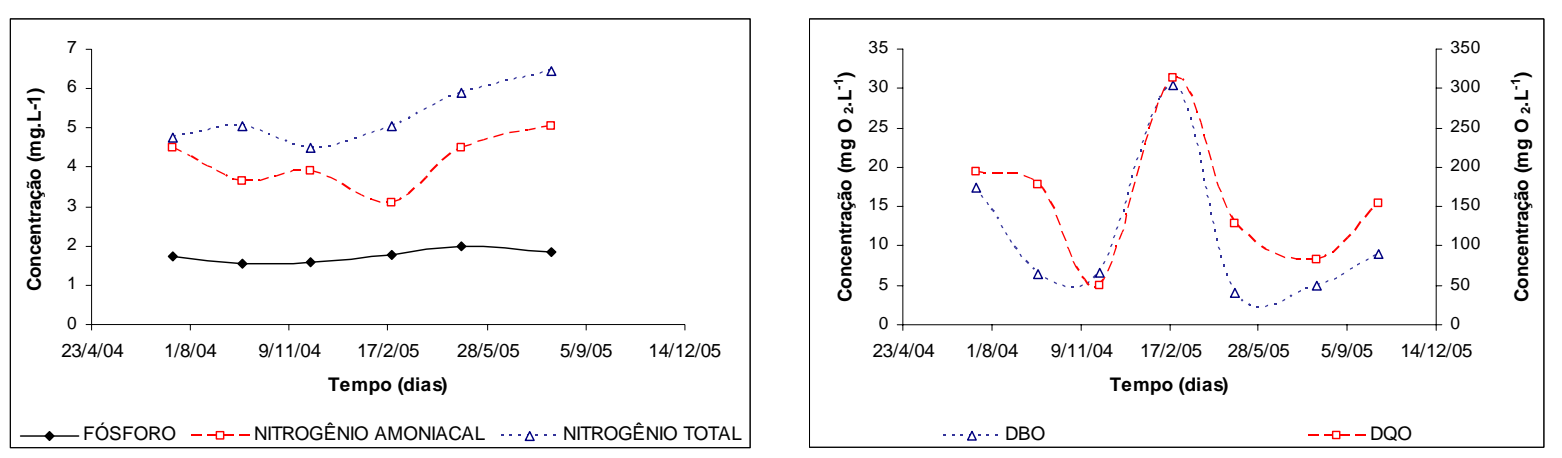

Figura 9. Variação da concentração dos nutrientes (a) e da DBO e DQO (b) da água do açude Pedreira em função do tempo.

Esse fato pode ter sido causado inicialmente pela degradação da matéria orgânica pelos microorganismos presentes no açude e, em seguida, devido à diminuição ainda maior do nível, vários aguapés morreram aumentando a matéria orgânica (Figura 9b); com a retirada dos aguapés os valores tornaram a decrescer.

A explicação da variação do teor dos compostos nitrogenados e de fósforo para esse reservatório, segue a mesma do açude Xaréu, cujo comportamento e valores se apresentam próximos ao do açude da Pedreira.

$\mathrm{O}$ pH manteve-se estável ao longo do período analisado e a condutividade elétrica cresceu devido ao aumento de sais (Figura 10a). Devido a problemas com o equipamento não se pode mais continuar o monitoramento da condutividade.

O elevado valor para a concentração de sólidos totais (ST) na primeira análise foi devido à dificuldade de coleta, provocando o arraste de lama e aumentando assim esse teor. Pode-se observar que a partir do $2^{\circ}$ ponto tem-se um aumento da concentração de ST, que está de acordo como os dados da condutividade (Figura 10b).
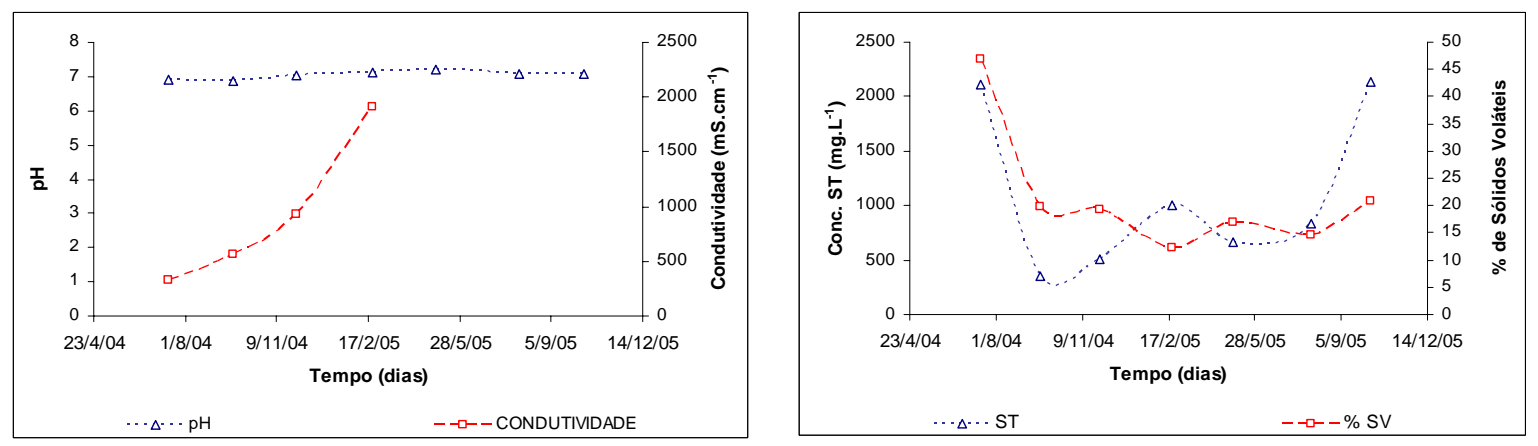

Figura 10. Variação do $\mathrm{pH}$ e da condutividade (a) e dos sólidos totais (ST) e porcentagem dos voláteis (b) em função do tempo para o açude Pedreira. 
O percentual de sólidos voláteis apresentou uma redução, indicando a degradação da matéria orgânica particulada. No primeiro ponto, quando foi arrastado um pouco de lama, pode-se verificar (Figura 10b) o elevado teor de matéria orgânica (aproximadamente 50\%).

\section{Açude Emas}

A principal utilização desse açude, Figura 11, é para a irrigação do projeto "Noronha Terra". Nesse projeto são cultivadas hortaliças para o consumo dos habitantes da ilha. No entorno desse açude, foi verificada também a criação de animais, principalmente bois e cavalos. Os excrementos desses animais podem infectar a água, reduzindo a sua qualidade. Por essa razão é importante que se faça uma cerca em torno do açude e que se coloque um sistema de drenagem para evitar não só a entrada de resíduos desses animais como também de fertilizantes, provenientes da irrigação. Essa água está com resíduos de fertilizantes que aumentam o teor de compostos nitrogenados e fosfatados na água. Foi também observada a existência de tubulações de irrigação quebradas e uma grande quantidade de girinos.

Esse açude verte para o açude do Boldró, após atravessar a BR, próximo à entrada para o forte do Boldró. Foi constatado que mesmo com o baixo nível, há uma saída de água. Essa saída é uma perda que ocorre pelo paredão ao lado da BR.

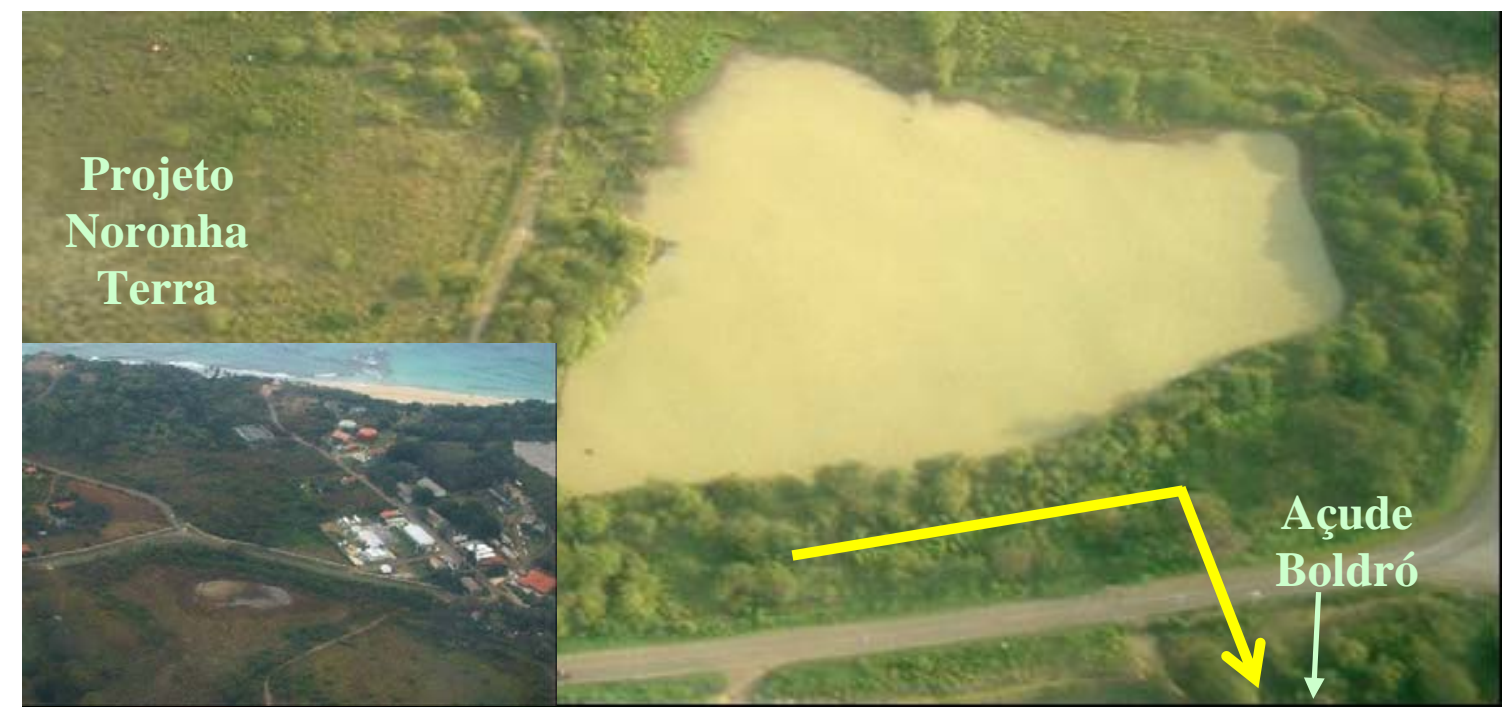

Figura 11. Vista aérea do açude Emas e a situação dele em agosto de 2005 no detalhe.

Essa água que percola a barreira da barragem (linha amarela da Figura 11), passa por baixo da BR e segue para o açude Boldró, o qual está assoreado e recebe a saída da lagoa de tratamento de efluente, cuja eficiência é muito baixa.

Uma opção bastante viável é a colocação de um dreno com um cacimbão para a coleta dessa água, a qual pode ser bombeada para estação de tratamento de água da COMPESA. Outra opção é a remoção da areia que assoreia o açude Boldró (que pode ser utilizada na construção pela administração da ilha) e o desvio da saída da lagoa de tratamento da COMPESA para jusante desse açude. Assim a água acumulada no Boldró pode ser bombeada para a estação da COMPESA.

O período da estiagem também afetou muito esse manancial, deixando-o completamente seco em agosto de 2005. Desta forma foram realizadas análises nesse corpo hídrico até o mês de maio de 2005. Vale ressaltar que no mês de maio não foi mais observada a perda de água pelo paredão, uma vez que o nível não mais o atingia. 


\section{Análises Físico-Químicas}

Foi verificado durante o período observado que os teores de nitrogênio total e de nitrogênio amoniacal mantiveram-se estáveis e redução de concentração de fósforo (Figura 12a).
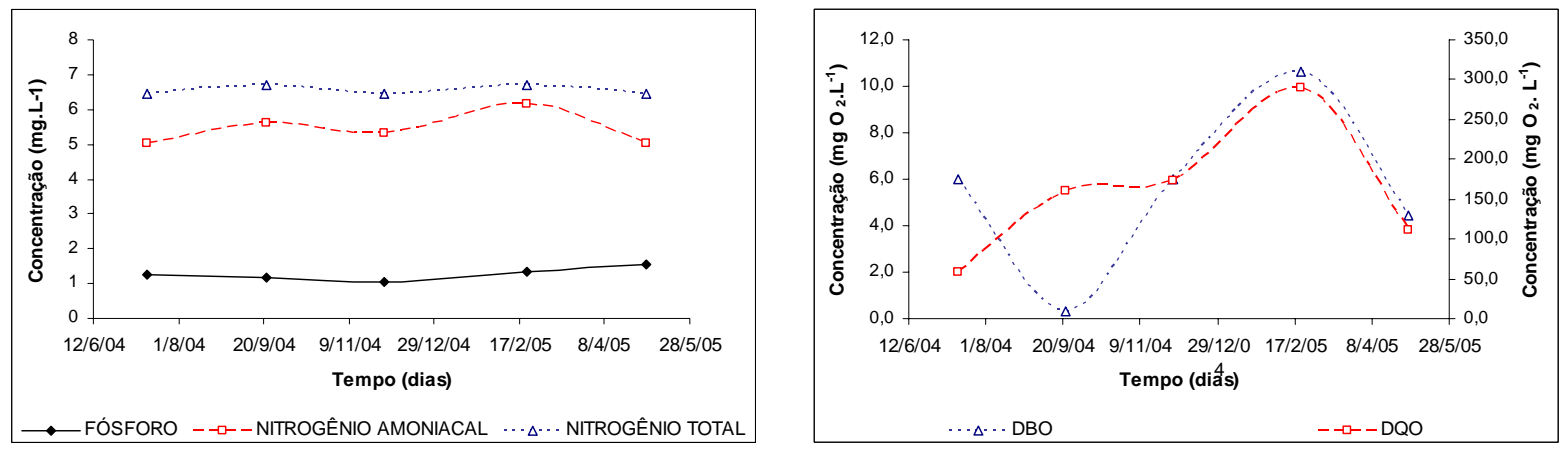

Figura 12. Variação da concentração dos nutrientes (a) e da DBO e DQO (b) da água do açude Emas em função do tempo.

Houve, contudo, um aumento substancial na matéria orgânica desse corpo d'água tanto em termos de $\mathrm{DBO}_{5}$ quanto de DQO (Figura 12b) até o mês de fevereiro de 2005. Esse aumento pode estar relacionado aos excrementos de animais e aos resíduos agrícolas e de fertilizantes. Em seguida, com a redução substancial do seu volume e não havendo mais entrada de água do retorno da irrigação nem da pecuária, esses valores foram reduzidos substancialmente.

Ao contrário dos outros açudes, as concentrações de nitrogênio amoniacal e total não apresentaram um incremento com o tempo, estando estáveis durante todo o período de monitoramento.. Esse fato vem corroborar com a justificativa para o aumento da concentração nos outros açudes, ocasionada pela degradação dos aguapés, que não estão presentes nesse reservatório. Todavia, a concentração de fósforo permaneceu estável para os outros corpos d'água.

Foram observados elevados valores do $\mathrm{pH}$ nesse açude em relação aos outros estudados (Figura 13a). Como fora citado anteriormente, esse elevado valor pode estar associado ao aporte de resíduos de fertilizantes (utilização de nitrogênio na forma amoniacal). Essa hipótese é reforçada pelos teores mais elevados de nitrogênio total e amoniacal encontrados nesse açude.
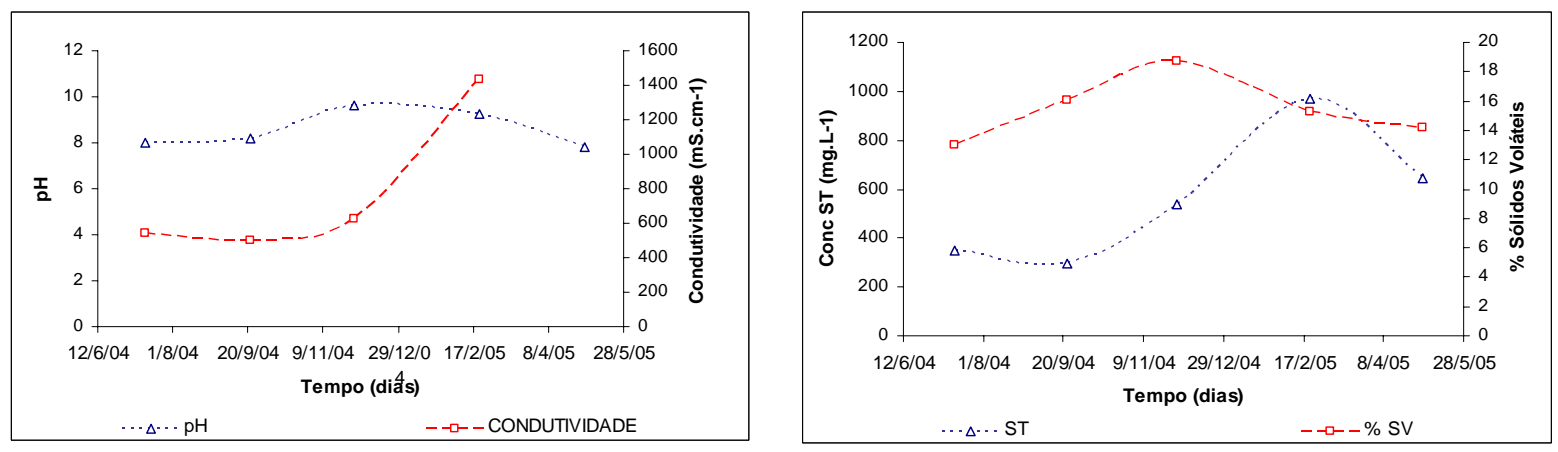

Figura 13. Variação do $\mathrm{pH}$ e da condutividade (a) e dos sólidos totais (ST) e porcentagem dos voláteis (b) em função do tempo para o açude Emas. 
Assim como para os outros dois açudes citados, foi também constatado um aumento da condutividade, sobretudo nas duas últimas análises (Figura 13a).

Além da condutividade, o teor de sólidos totais também apresentou um aumento considerável (Figura 13b). Esses fatos são devido à redução de nível do açude pela evaporação e consumo e por não haver aporte de água (proveniente da chuva). $\mathrm{O}$ valor mais elevado no mês de fevereiro pode ter sido pela presença de girinos, tendo sido necessário removê-los para que a coleta fosse realizada.

$\mathrm{O}$ açude Emas apresentou elevados valores para a turbidez. Vale então lembrar que esse é um dos dois açudes que não tem presença de aguapés. Uma hipótese para a não proliferação desse aguapé pode ser essa elevada turbidez que impede a penetração dos raios solares necessários para o metabolismo vegetal.

\section{CONCLUSÕES}

De uma forma geral, a qualidade da água dos reservatórios foi se deteriorando, devido principalmente à morte dos aguapés e á falta de chuva, com aporte de água. Todavia, a água pode ser utilizada para abastecimento após um tratamento, que com o aumento de impurezas, torna-se cada vez mais oneroso.

Pode-se constatar um aumento da concentração da DBO, DQO, sólidos e, sobretudo, da condutividade, devido à redução do volume de água e à degradação das plantas. A salinização do açude e a quantidade de matéria orgânica, podem comprometer a qualidade da água quando do novo aporte de água. Novos estudos serão realizados no sentido de se avaliar essa influência.

Foi constatado o aumento da concentração do nitrogênio amoniacal e total, devido à degradação da vegetação presente nos açudes e uma estabilidade nos valores das concentrações de fósforo.

Durante o período de monitoramento, foram feitas sucessivas campanhas para retirada dos aguapés, que tornavam a aparecer em pouco tempo. Constatou-se que no açude Emas, que apresenta elevada turbidez da água não há infestação destes, logo a transparência da água é fundamental para a reprodução das sementes dos aguapés que devem estar no interior dos açudes. Para uma remoção total dessas plantas faz-se necessário, além da remoção um tratamento com algicida que não comprometa a qualidade da água para abastecimento humano.

Uma re-estruturação do sistema de abastecimento da ilha é urgente para evitar novos problemas de racionamento e risco de colapso. A limpeza dos açudes Xaréu e Pedreira com a remoção dos aguapés, vegetação e animais mortos é necessária e atualmente está sendo realizada. Faz-se necessária também a limpeza do açude Mulungu antes que as chuvas comecem a enchê-lo, assim como a manutenção desses corpos hídricos.

É necessária uma avaliação do sistema de irrigação do projeto "Noronha Terra", para avaliar a entrada de poluentes e restos de fertilizantes e resíduos de animais no açude Emas.

Vale frisar que o abastecimento de água é fundamental para o desenvolvimento da ilha, cuja indústria principal é o turismo. Monteiro Filho e Borges (2003) citam que em 2002 a entrada de turistas na ilha ficou limitada a 180 pessoas por dia, o que representou uma redução de $20 \%$ em relação ao número de visitantes anteriores, devido à falta d'água. 


\section{AGRADECIMENTOS}

Os autores agradecem à Administração da Ilha de Fernando de Noronha, a TRIP Linhas Aéreas pelo transporte das amostras da ilha até Recife, ao CNPq pelo financiamento do projeto e aos pesquisadores que colaboram com este projeto na pessoa dos pesquisadores Ernesto Batista da Silva Filho e Noélia Mirna Martins Pereira.

\section{REFERÊNCIAS}

AMERICAN PUBLIC HEALTH ASSOCIATION (APHA). Standard methods for the examination of water and wastewater. 19. ed. Washington: APHA. AWWA. WEF, 1995.

BARROS, J. A. L. Relatório prévio sobre a expedição João Alberto à ilha da Trindade. Rio de Janeiro: [S.n.], 1959. 75 p.

CARVAlHO, F. T.; VELINI, E. D.; NEGRISOLI, E.; ROSSI, C. V. S. Eficácia do carfentrazone-ethyl no controle de plantas aquáticas latifoliadas em caixas-d'água. Planta Daninha, v. 23, n. 2, p. 305-310, 2005.

CARVALHO, L. F. A. Impactos do turismo no arquipélago de Fernando de Noronha: um estudo no caminho do desenvolvimento sustentável. 1999. 126f. Trabalho de Conclusão de Curso (Curso de Turismo) - Departamento de Relações Públicas, Propaganda e Turismo, Universidade de São Paulo, São Paulo, 1999.

COMPANHIA PERNAMBUCANA DE ÁGUA E ESGOTO - COMPESA. Elo Fernando de Noronha: um pouco que foi feito. Disponível em: <www.compesa.com.br $>$. Acesso em: 5 jun. 2007.

DA MOTTA, M. Relatório técnico de visita realizada no período de 09 a 11 de Outubro de 2005, no projeto "Disponibilidade de Recursos Hídricos Superficiais em Fernando de Noronha". Recife: Departamento de Engenharia Química, UFPE, 2005.

DA MOTTA, M., PEREIRA, N. M. M. Relatório técnico de visita realizada no período de 25 a 27 de Julho de 2006, no projeto "Disponibilidade de Recursos Hídricos Superficiais em Fernando de Noronha”. Recife: Departamento de Engenharia Química, UFPE, 2006.

KIRCHMANN, H. Animal and municipal organic wates and water quality. In: LAL, R.; STEWART, B. A. (Ed.). Soil processes and water quality: advances in soil science. Boca Raton: Lewis Publishers, 1994. p. 163-232.

KOSKI-VAHALA, J.; HARTIKAINEN, H. Assessment of the risk of phosphorus loadin due to resuspended sediment. Journal of Environmental Quality, v. 30, p. 960-966, 2001.

MONTEIRO FILHO, M., BORGES, J. Sombras no paraíso: pousadas domiciliares de Fernando de Noronha lutam para manter espaço. Problemas Brasileiros, mai.jun. 2003, p. 16-18.

MUCHOVEJ, R. M. C.; RECHCIGL, J. E. Impact of nitrogen fertilization of pastures and turfgrasses on Water Quality. In: LAL, R.; STEWART, B. A. Soil process and water quality: advances in soil science. Boca Raton: Lewis publishers, 1994. 398 p. 
OWENS, L. B. Impacts of soil N management on the quality of surface and subsurface water. In: LAL, R.; STEWART, B. A. (Ed.). Soil processes and water quality: advances in soil science. Boca Raton: Lewis Publishers, 1994. p. 137-162.

PLANTAMED. Disponível em: <http://www.plantamed.com.br/plantaservas/image/Pistiastratiotes.html>. Acesso em: 10 nov. 2005.

POTT, V. J.; POTT, A. Plantas aquáticas do Pantanal.. Corumbá: EMBRAPA/CPAP, 2000. $404 \mathrm{p}$.

ROCHA, A.T.; DUDA, G. P.; NASCIMENTO, C. W. A.; RIBEIRO, M. R. Fracionamento do fósforo e avaliação de extratores do P-disponível em solos da Ilha de Fernando de Noronha. Revista Brasileira de Engenharia Agrícola e Ambiental, v. 9, n. 2, p. 178184, 2005.

SHARPLEY, A. N. The enrichment of soil phosphorus in runoff sediments. Journal of Environmental Quality, v. 9, p. 521-526, 1980.

SHARPLEY, A.; DANIEL, T.; WRIGHT, B.; KLEINMAN, P.; SOBECKI, T.; PARRY, R.; JOERN, B. National research project to identify sources of agricultural phosphorus loss. Better Crops, n. 83, p. 12-15, 1999.

SILVA JÚNIOR, J. M. Parque nacional marinho de Fernando de Noronha: uso público, importância econômica e proposta de manejo. In: SIMPÓSIO DE ÁREAS PROTEGIDAS CONSERVAÇÃO NO ÂMBITO DO CONE SUL, 2., 13 a 15 de Out. 2003, Pelotas. . Anais... Pelotas: UCPEL, 2003. 


ISSN = 1980-993X - doi:10.4136/1980-993X
www.agro.unitau.br/ambi-agua
E-mail: ambi-agua@agro.unitau.br
Tel.: (12) 3625-4116

\title{
Principais usos da água do rio Sanhauá na área de influência do antigo lixão do Roger: proposta de revisão de enquadramento do rio
}

(doi:10.4136/ambi-agua.67)

\author{
Gilson Barbosa Athayde Júnior'; Claudia Coutinho Nóbrega²; Carmem Lúcia \\ Moreira Gadelha ${ }^{3}$; Natalia Cibely Bezerra Santana ${ }^{4}$; Magdalena Duarte Costa ${ }^{5}$
}

Departamento de Engenharia Civil e Ambiental, Centro de Tecnologia, Universidade Federal da Paraíba, Bairro Castelo Branco, João Pessoa-PB, Cep: 58.059-900

E-mail: ${ }^{1}$ gilson@ct.ufpb.br; ${ }^{2}$ claudiacn@uol.com.br; ${ }^{3}$ carmemgadelha@yahoo.com.br

${ }^{4}$ Bolsista de Iniciação Científica CNPq/UFPB

E-mail: natalianet@msn.com

${ }^{5}$ Mestranda em Engenharia Urbana pela Universidade Federal da Paraíba. Bolsista CT-Hidro - CNPq

E-mail: magdalenadcosta@yahoo.com.br

\section{RESUMO}

Verificaram-se os principais usos das águas do rio Sanhauá nas proximidades do antigo lixão do Roger, em João Pessoa. As visitas ao local foram realizadas em março, agosto e novembro de 2006 e fevereiro, maio e agosto de 2007. Foram identificadas atividades, como pesca, exploração de crustáceos e mariscos, navegação, recreação de contato primário, lançamento de esgoto, disposição de resíduos sólidos e dispersão do chorume gerado no antigo lixão. Dos entrevistados, 50,2\% declararam que utilizam o rio Sanhauá para pesca ou coleta de mariscos ou captura de crustáceos, $45,8 \%$ responderam que utilizam o rio para recreação de contato primário, contato secundário ou navegação, 93,1\% dos entrevistados responderam que o seu domicílio não é atendido por serviço público de esgotamento sanitário e com isso o destino final dos esgotos é o rio Sanhauá, e 46,6\% declararam que têm conhecimento de disposição de resíduos sólidos no rio, apesar de 100\% dos domicílios serem atendidos por serviço de coleta de lixo. Segundo esses usos, a Resolução CONAMA N ${ }^{\circ}$ 357/2005 e a salinidade da água, o enquadramento do rio Sanhauá seria de água salobra classe 1, mas atualmente ele é enquadrado na classe 3 de água doce. O monitoramento da qualidade da água mostrou que os padrões de qualidade estão em desacordo com a classe 1 para águas salobras, fazendo-se necessário por parte do poder público a adoção de medidas no sentido de compatibilizar os usos existentes com a qualidade da água do rio ou a revisão do enquadramento do corpo aquático.

Palavras-chave: usos da água; rio Sanhauá; antigo lixão do Roger, João Pessoa.

\section{Main usages of Sanhauá river water in the area of influence of the former Roger's open dump: revising proposal of its classification}

\section{ABSTRACT}

The main usages of surface water near to the former Roger's open dump were investigated by means of visits every three months. These visits were performed in: March 2006, August 2006, November 2006, February 2007, May 2007 and August 2007. The following activities were identified: fishing, crustacean and shellfish catchments, primary contact bath, discharge of sewage, disposal of solid wastes, and discharge of leachate generated by the former open dump. Furthermore, social-economical questionnaires were 
applied to the people living nearby. Results showed that $50.2 \%$ of interviewed people stated that uses the Sanhauá river water for fishing or crustacean or shellfish catchments; $45.8 \%$ said that use the river for primary or secondary contact bath or navigation; $93.1 \%$ of interviewed people said that their houses were not attended with sewage and so that, the final disposal site for the sewage was the Sanhauá river. Although all houses are attended by solid waste collection services, $46.6 \%$ of the interviewed people declared to know about solid wastes disposal at the Sanhauá river. According to these usages and CONAMA Resolution 357/2005 and the water salinity, the Sanhauá river would be classified into class 1 for brackish water, as opposed to its present classification: class 3. The monitoring showed that water quality standards were not in accordance to the class 1 for brackish water. Therefore, the environmental institution should adopt measures so that the water quality of Sanhauá river would be maintained or proceed to the revision for the river classification.

Keywords: water usages; Sanhauá river; Roger’s open dump.

\section{INTRODUÇÃO}

A importância da água reside no fato de ela ser essencial ao ser humano, ao desenvolvimento econômico e à preservação do meio ambiente. No que se refere ao ser humano, estima-se que, para atender às suas necessidades fisiológicas, uma pessoa precise de 2 a 3 litros de água por dia, embora o consumo per capita mínimo necessário para manter uma boa saúde seja da ordem de 100 L/dia. Essa quantidade de água supre, além das necessidades fisiológicas, outros usos, como higiene e preparação de alimentos. A saúde pública é igualmente dependente do acesso à água de boa qualidade, já que as doenças relacionadas com a água atingem no mundo mais de 1 bilhão de pessoas por ano, levando à morte, aproximadamente, 3 milhões. Esses números poderiam ser facilmente reduzidos se a população tivesse acesso a um serviço de saneamento adequado. No que se refere aos aspectos econômicos, a água serve de insumo para várias atividades, destacando-se a geração de energia, agricultura irrigada, abastecimento público e produção industrial. No Brasil, por exemplo, as usinas hidrelétricas são responsáveis por mais de $90 \%$ da energia gerada no país. Inúmeros processos industriais/agrícolas necessitam direto ou indiretamente de água para a sua realização. Além disso, o meio ambiente também é extremamente dependente e vulnerável a alterações das condições hidrológicas. A água possui um papel importante na manutenção dos ecossistemas, como por exemplo, os costeiros e os pântanos, que são particularmente vulneráveis, pois alterações hidrológicas podem levar a catástrofes ambientais irrecuperáveis (Vasconcelos et al, , 2008).

Apesar das fontes de água serem abundantes ao redor do planeta, são mal distribuídas. No Brasil, que possui grande disponibilidade de recursos hídricos, esse fato é bastante evidente, visto que a maior porcentagem (68,5\%) desses recursos está concentrada na região Norte onde habitam 7,6\% da população brasileira, enquanto que as regiões de maiores índices populacionais concentram poucos recursos hídricos: apenas 6\% no Sudeste e pouco mais de $3 \%$ no Nordeste, para uma população de 42,6\% e 28,1\%, respectivamente (Dias, 2007).

Além de mal distribuídas, atualmente as águas vêm sendo poluídas num ritmo bastante intenso. Poluição das águas pode ser definida como qualquer adição de matéria ou energia que altere as características naturais das águas de modo a limitar os usos previstos para ela (Brasil, 1981). A poluição da água pode indicar que um ou mais de seus usos preestabelecidos foram prejudicados. No Brasil, as águas doces, salobras e salinas são classificadas em trezes

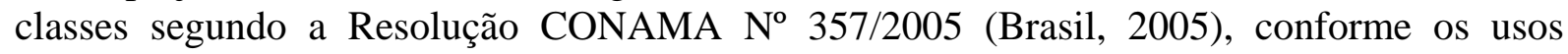
preponderantes destas. A partir disso, os parâmetros de qualidade da água são definidos para 
cada uma dessas classes, que devem ser seguidos para garantir a compatibilidade entre o uso e a qualidade. É importante atentar para o fato de que o enquadramento dos corpos de água deve estar baseado não necessariamente no seu estado atual, mas nos níveis de qualidade que deveriam possuir para atender aos padrões de qualidade da água da classe a que pertencem.

Dentre as diversas fontes possíveis de poluição hídrica, encontram-se os lixões, que apesar de serem uma forma inadequada de disposição final de resíduos sólidos, continuam sendo áreas para simples descarga do lixo sobre o solo, sem medidas de proteção ao meio ambiente ou à saúde pública. Segundo a pesquisa de saneamento básico do Instituto Brasileiro de Geografia e Estatística - IBGE (IBGE, 2000), 30,5\% dos resíduos sólidos produzidos no Brasil são destinados a lixões, enquanto que esse percentual para aterros controlados e aterros sanitários é de 22,3\% e 47,1\%, respectivamente.

O antigo lixão do Roger localizado na região Metropolitana de João Pessoa possui uma área de 17 ha e funcionou como depósito a céu aberto por mais de 40 anos, quando na verdade deveria ter uma vida útil de apenas 3 anos. Com o fechamento, pelo Ministério Público, dos lixões de Bayeux e Cabedelo, o antigo lixão do Roger passou a receber também o lixo proveniente dessas cidades, chegando a totalizar em média 900 toneladas/dia de resíduos domicialiares, hospitalares e entulhos (EMLUR, 2003). O antigo lixão do Roger está assentado no manguezal às margens do rio Sanhauá, um dos mais importantes do estado da Paraíba.

Apesar de ter sido desativado em 5 de agosto de 2003, o antigo lixão do Roger tem gerado grandes problemas de poluição e degradação dos cursos de água, na área do manguezal e na porção estuarina do rio Sanhauá, principalmente nas suas proximidades. $\mathrm{O}$ antigo lixão do Roger causa diversos efeitos negativos sobre o meio ambiente, principalmente devido à percolação do chorume, que pode ser definido (Segato e Da Silva, 2000; Martínez e Soto, 2000; Russo et al, 2000; Pessin et al, , 2000) como um líquido escuro altamente poluidor gerado pela degradação dos resíduos presentes no lixo. Ele é originado da umidade natural do lixo (aumentando no período chuvoso), da água de constituição da matéria orgânica que escorre durante o processo de decomposição e das bactérias existentes no lixo que expelem enzimas dissolvendo a matéria orgânica com formação de líquido. O chorume infiltra-se no solo, contaminando as águas subterrâneas e pelo escoamento superficial polui as águas superficiais. Assim, quando os resíduos sólidos não têm destinação adequada se transformam numa grande ameaça não somente para o meio ambiente como também para saúde pública, principalmente para a população que vive nas proximidades, que no caso do antigo lixão do Roger, pode-se citar a comunidade do Porto do Capim e da Favela do "S".

Nesse contexto, o objetivo do presente trabalho é caracterizar os principais usos da águas superficiais e manguezais na área de influência do antigo lixão do Roger, visando orientar medidas e ações por parte do poder público e órgãos ambientais, de maneira a minimizar os conflitos existentes, assegurar os padrões de qualidade da água e revisar o enquadramento do rio Sanhauá.

\subsection{Usos da água}

Os usos da água podem ser separados em grandes grupos (Bassoi e Guazelli, 2004): abastecimento público e industrial, irrigação e a dessedentação de animais, preservação da fauna e da flora aquática, recreação, geração de energia elétrica, navegação, diluição e transporte de efluentes. Desses usos listados, pode-se dizer que são consuntivos: o abastecimento humano e industrial, irrigação e dessedentação de animais, enquanto que recreação, conservação da flora e fauna, geração de energia elétrica, navegação, transporte de efluentes são não consuntivos.

O abastecimento doméstico é considerado o uso mais nobre associado aos recursos hídricos, visto que requer diversos critérios de qualidade da água. Além disso, o uso 
doméstico é a categoria mais homogênea, apresentando pequena variabilidade de consumo. A água destinada para o abastecimento doméstico é utilizada na área interna e externa da habitação. Engloba o consumo da água para beber, para fins alimentares e para higiene pessoal, sendo utilizada também para lavagem de roupas e de utensílios domésticos, irrigação de jardins, lavagem de veículos e limpeza em geral.

O abastecimento público engloba a utilização da água para irrigação de parques e jardins, lavagem de ruas e passeios, edificações e sanitários de uso público, fontes ornamentais, piscinas públicas, combate a incêndios, limpeza de coletores de esgotos, etc. Já o abastecimento comercial e industrial são os mais heterogêneos, ocorrendo desde pequenos consumidores de água como bares, padarias e pequenas indústrias artesanais, até grandes consumidores de água como shopping center e indústrias de bebida. A água de uso industrial é utilizada pela indústria nos processos de fabricação de seus produtos, como lavagem das matérias-primas e de equipamentos, usada também na alimentação de caldeiras e processos industriais em geral.

A irrigação é a atividade humana que mais utiliza água: $70 \%$ do consumo global (Shiklomanov, 1999). A qualidade da água usada para a irrigação varia em função dos tipos de culturas em que será aplicada, se alimentícias ou não.

Quanto à recreação, esse uso destina-se a atividades de dois tipos: contato primário, que tem imersão do corpo na água, e contato secundário que não tem imersão do corpo. A qualidade da água, principalmente nas atividades de contato direto com a água (contato primário), está baseada na presença de microorganismos patogênicos que transmitem doenças, colocando em risco a saúde humana.

A geração de energia elétrica utiliza o recurso hídrico de maneira a não modificar a qualidade da água captada, entretanto altera o ambiente e a vida aquática gerando conflitos entre os outros usos.

A preservação da fauna e da flora está relacionada com a qualidade da água, portanto os parâmetros utilizados na classificação das águas em seus usos preestabelecidos devem ter valores rígidos para garantir a vida aquática, incluindo os peixes, as aves e outros animais.

Diluição e transporte de efluentes: trata-se do uso menos nobre das águas, entretanto um dos mais utilizados pelo homem. A maior parte da água para consumo humano vem dos rios e é neles que são lançados os efluentes de natureza doméstica e/ou industrial, prejudicando o uso das águas receptoras. É preciso atentar para a importância do tratamento dos efluentes e de como são dispostos no meio ambiente, visto que alteram a qualidade da água tornando-a imprópria para outros fins.

Alguns desses usos provocam alterações na qualidade da água, podendo prejudicar o próprio uso gerador do conflito ou outros de maior importância. Na irrigação, por exemplo, parte da água utilizada não retorna ao corpo de água original e a parte que retorna tem qualidade inferior à captada (uso consuntivo), podendo torná-la imprópria para outros usos. Na recreação, por sua vez, ao modificar as características da água, esse uso prejudica o abastecimento humano.

\subsection{Monitoramento da qualidade da água como subsídio ao gerenciamento dos Recursos Hídricos}

Segundo Ward (1999, apud Soares e Lisot, 2007), um sistema de monitoramento ou sistema de informações de qualidade da água consiste de amostragem (localização dos pontos de coleta, escolha das variáveis, determinação da freqüência e tipo de amostragem estatística), análise laboratorial, manuseio de dados, preparação de relatórios e utilização dos dados obtidos para efeito de tomada de decisão.

Para realizar o monitoramento de um corpo aquático, utiliza-se a análise de parâmetros físicos, químicos e biológicos, tais como: $\mathrm{pH}$, turbidez, sólidos (totais, dissolvidos), cor, 
condutividade elétrica, OD, DBO, DQO, nitrato, nitrito, fósforo total, chumbo, cloretos, alumínio, coliformes (totais e termotolerantes).

\subsection{Enquadramento dos corpos aquáticos}

Conforme a Política Nacional de Recursos Hídricos, (Brasil, 1997), o enquadramento dos corpos hídricos em classes, segundo os usos preponderantes da água, visa assegurar às águas qualidade compatível com os usos mais exigentes a que forem destinadas e diminuir os custos de combate à poluição das águas, mediante ações preventivas permanentes.

De acordo com a Resolução CNRH No 12/2000 (Brasil, 2000a), os procedimentos para o enquadramento de corpos aquáticos em classes segundo os usos preponderantes deverão ser desenvolvidos observando as seguintes etapas:

I - diagnóstico do uso e da ocupação do solo e dos recursos hídricos na bacia hidrográfica;

II - prognóstico do uso e da ocupação do solo e dos recursos hídricos na bacia hidrográfica;

III - elaboração da proposta de enquadramento; e

IV - aprovação da proposta de enquadramento e respectivos atos jurídicos.

Na etapa de diagnóstico serão abordados os seguintes itens:

I - caracterização geral da bacia;

II - aspectos jurídicos e institucionais;

III - aspectos socioeconômicos;

IV - uso e ocupação atual do solo;

V - identificação das áreas reguladas por legislação específica e das áreas em processo de degradação;

VI - usos, disponibilidade e demanda atual de águas superficiais e subterrâneas;

VII - identificação das fontes de poluição pontuais e difusas atuais oriundas de efluentes domésticos e industriais, de atividades agropecuárias e de outras fontes causadoras de degradação ambiental sobre os recursos hídricos; e

VIII - estado atual dos corpos hídricos, apresentando a condição de qualidade por trecho, consubstanciado por estudos de autodepuração.

Na etapa de prognóstico serão formuladas projeções com horizontes de curto, médio e longo prazos, objetivando o desenvolvimento sustentável, que incluirão:

I - evolução da distribuição das populações e das atividades econômicas;

II - evolução de usos e ocupação do solo;

III - políticas e projetos de desenvolvimento existentes e previstos;

IV - evolução da disponibilidade e da demanda de água;

V - evolução das cargas poluidoras dos setores urbano, industrial, agropecuário e de outras fontes causadoras de degradação ambiental dos recursos hídricos;

VI - evolução das condições de quantidade e qualidade dos corpos hídricos, consubstanciada em estudos de simulação; e

VII - usos desejados de recursos hídricos em relação às características específicas de cada bacia.

Na etapa de elaboração da proposta de enquadramento serão desenvolvidas, para cada projeção, alternativas de enquadramento: uma de referência e uma ou mais prospectivas, todas com base nas informações obtidas e nas avaliações feitas nas etapas de diagnóstico e prognóstico.

$\mathrm{Na}$ etapa de aprovação da proposta de enquadramento e respectivos atos jurídicos deverão ser observados os procedimentos previstos na Resolução CNRH Nº12/2000 e 
segundo essa mesma Resolução o enquadramento dos corpos aquáticos em classes deve obedecer às normas estabelecidas na legislação ambiental específica.

No Brasil, a Resolução CONAMA No 357/2005 (Brasil, 2005), dispõe sobre a classificação dos corpos de água e diretrizes ambientais para o seu enquadramento. As águas do território nacional foram divididas em águas doces (salinidade $<0,5 \%$ ), salobras (salinidade entre 0,5\% e 30\%o) e salinas (salinidade > 30\%o). Em função da qualidade requerida para os seus usos preponderantes, foram criadas 13 classes de qualidade.

A classificação das águas salobras é:

I - Classe especial: águas destinadas: integral;

a) à preservação dos ambientes aquáticos em unidades de conservação de proteção

b) à preservação do equilíbrio natural das comunidades aquáticas.

II - Classe 1: águas que podem ser destinadas:

a) à recreação de contato primário, conforme Resolução CONAMA N² 274/2000 (Brasil, 2000b);

b) à proteção das comunidades aquáticas;

c) à aqüicultura e à atividade de pesca;

d) ao abastecimento para consumo humano após tratamento convencional ou avançado;

e) à irrigação.

III - Classe 2 : águas que podem ser destinadas:

a) à pesca amadora;

b) à recreação de contato secundário.

IV - Classe 3: águas que podem ser destinadas:

a) à navegação;

b) à harmonia paisagística.

Os padrões de qualidade das águas determinados na Resolução CONAMA Nº 357/2005, no seu Capítulo III, estabelecem limites individuais para cada substância em cada classe.

\section{MATERIAIS E MÉTODOS}

Para caracterizar os principais usos da água do rio Sanhauá (João Pessoa, PB) foi feito um monitoramento trimestral pelo levantamento de dados in situ em visitas à área de influência direta e também indireta do antigo lixão do Roger, compreendendo toda a porção estuarina do rio Sanhauá até sua confluência com o rio Paraíba do Norte. O antigo lixão do Roger se localiza na porção oeste de João Pessoa, adjacente ao manguezal às margens do rio Sanhauá (e Paraíba do Norte), conforme ilustrado na Figura 1. As visitas ao local foram realizadas em março, agosto e novembro de 2006 e fevereiro, maio e agosto de 2007. Os dados foram obtidos por meio da aplicação de questionário socioambiental (Tabela 1) aos moradores das comunidades do Porto do Capim e da favela do "S", ambas localizadas nas proximidades do lixão. 
ATHAYDE JÚNIOR, G. B.; NÓBREGA, C. C.; GADELHA, C. L. M.; SANTANA, N. C. B.; COSTA, M. D. Principais usos da água do rio Sanhauá na área de influência do antigo lixão do Roger: proposta de revisão de enquadramento do rio. Ambi-Agua, Taubaté, v. 3, n. 3, p. 128-142, 2008. (doi:10.4136/ambi-agua.67)

Tabela 1. Questionário aplicado à população do Porto do Capim e Favela do "S".

\begin{tabular}{|c|c|c|c|c|}
\hline & \multirow[b]{2}{*}{ QUESTIONÁRIO } & \multicolumn{3}{|c|}{ Resultados (\%) } \\
\hline & & Sim & Não & $\begin{array}{c}\text { Não } \\
\text { soube/não } \\
\text { quis opinar }\end{array}$ \\
\hline 1 & $\begin{array}{l}\text { Você tem conhecimento de despejo de resíduos sólidos no rio Sanhauá no } \\
\text { entorno do porto do capim? }\end{array}$ & & & \\
\hline 2 & $\begin{array}{l}\text { Você tem conhecimento da existência de poços no entorno do antigo lixão do } \\
\text { Roger? }\end{array}$ & & & \\
\hline 3 & A água do rio Sanhauá é utilizada para abastecimento em seu domicílio? & & & \\
\hline 4 & $\begin{array}{l}\text { Alguém residente de seu domicílio utiliza o rio Sanhauá para pesca ou coleta } \\
\text { de mariscos ou captura de crustáceos? }\end{array}$ & & & \\
\hline 5 & $\begin{array}{l}\text { Alguém residente de seu domicílio utiliza o rio Sanhauá para recreação de } \\
\text { contato primário, contato secundário ou navegação? }\end{array}$ & & & \\
\hline 6 & Seu domicílio é atendido por serviço de abastecimento de água? & & & \\
\hline 7 & Seu domicílio é atendido por serviço publico de esgotamento sanitário? & & & \\
\hline 8 & Seu domicílio é atendido por serviço de coleta de resíduos sólidos? & & & \\
\hline 9 & $\begin{array}{l}\text { Você concorda com a forma com a qual o rio Sanhauá vem sendo tratado pelo } \\
\text { poder público? }\end{array}$ & & & \\
\hline 10 & $\begin{array}{l}\text { O rio Sanhauá no entorno do Porto do Capim, é utilizado para harmonia } \\
\text { paisagística? }\end{array}$ & & & \\
\hline 11 & $\begin{array}{l}\text { Você concorda com a forma com a qual o rio Sanhauá vem sendo tratado pela } \\
\text { população? }\end{array}$ & & & \\
\hline 12 & Há quanto tempo reside neste domicílio? Média & & & \\
\hline 13 & Quantas pessoas residem em seu domicílio? Média & & & \\
\hline 14 & Qual a renda familiar em seu domicílio? & & & \\
\hline 15 & Qual a máxima escolaridade em seu domicílio? & & & \\
\hline
\end{tabular}

Além da aplicação dos questionários foram feitos registros fotográficos de atividades (usos da água e manguezal) e para analisar a qualidade da água do Rio Sanhauá foram realizadas coletas pontuais de amostras de águas superficiais em quatro pontos localizados nas proximidades do antigo lixão do Roger. Tais pontos, denominados P1, P2, P3 e P4, são mostrados na Figura 1 e suas coordenadas geográficas são mostradas na Tabela 2.

Os parâmetros analisados foram: oxigênio dissolvido (OD), alumínio, chumbo, coliformes termotolerantes, nitrato e cloretos. As análises físico-químicas e microbiológicas seguiram as recomendações da APHA (1998).

Das etapas estabelecidas pela Resolução CNRH N¹2/2000 já descritas anteriormente para os procedimentos de enquadramento de corpos aquáticos segundo os usos preponderantes foi realizada nesse trabalho a etapa de diagnóstico envolvendo os seguintes itens: usos; identificação das fontes de poluição pontuais e difusas atuais oriundas de efluentes domésticos e industriais, de atividades agropecuárias e de outras fontes causadoras de degradação ambiental; e estado atual do corpo hídrico, apresentando a condição de qualidade por trecho. 


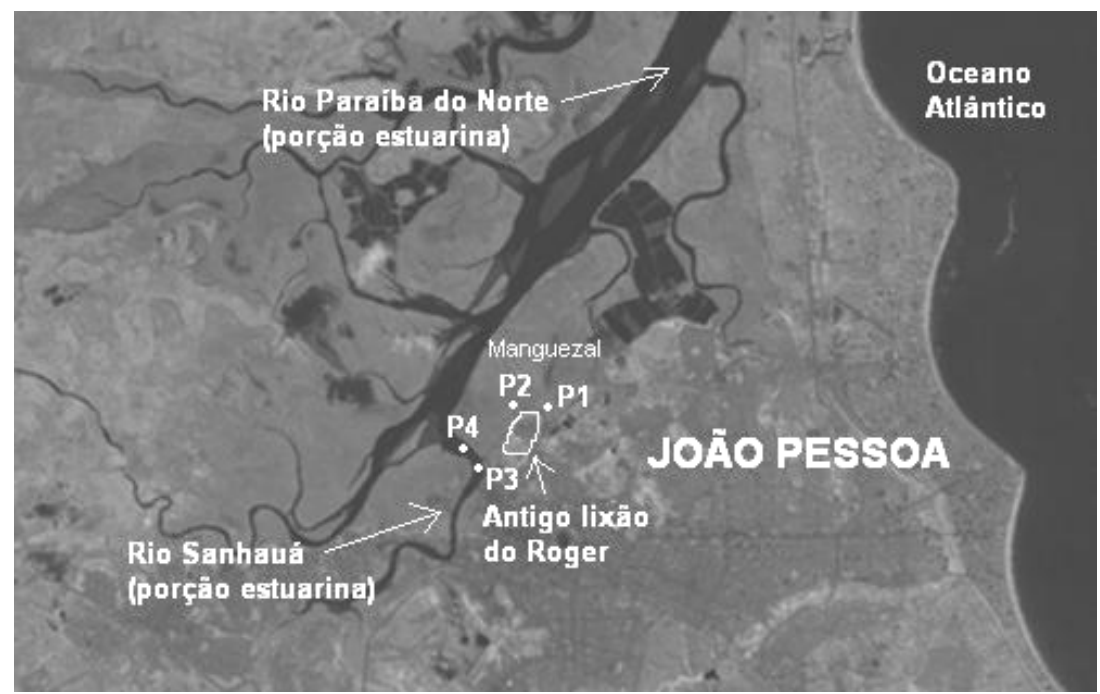

Figura 1. Localização da área de estudo e dos pontos P1, P2, P3 e P4. Fonte: INTERSAT (2001).

Tabela 2. Localização geográfica dos pontos de coleta.

\begin{tabular}{c|c|c|c}
\hline \multirow{2}{*}{ Ponto } & \multicolumn{2}{|c|}{ Coordenadas UTM } & \multicolumn{2}{c}{ Descrição } \\
\cline { 2 - 3 } & $\mathbf{E}$ & $\mathbf{N}$ & \\
\hline P1 & 292072 & 9214178 & Córrego afluente e sob influência de maré do rio Sanhauá \\
\hline P2 & 291629 & 9214276 & Córrego afluente e sob influência de maré do rio Sanhauá \\
\hline P3 & 291154 & 9213558 & Rio Sanhauá, à montante do antigo lixão do Roger \\
\hline P4 & 291141 & 9213774 & Rio Sanhauá, à jusante do antigo lixão do Roger \\
\hline
\end{tabular}

\section{RESULTADOS E DISCUSSÃO}

\subsection{Usos preponderantes da água do rio Sanhauá nas proximidades do antigo lixão do Roger}

Em relação à recreação de contato primário, contato secundário ou navegação observa-se que um percentual situado na faixa de 40-55\% (Figura 2) dos entrevistados faz uso das águas para essas atividades não consuntivas, o percentual médio foi de 45,8\%. Nas visitas realizadas na área de influência do antigo lixão do Roger verificou-se, principalmente, crianças tomando banho no rio, e uso de embarcações não motorizadas.

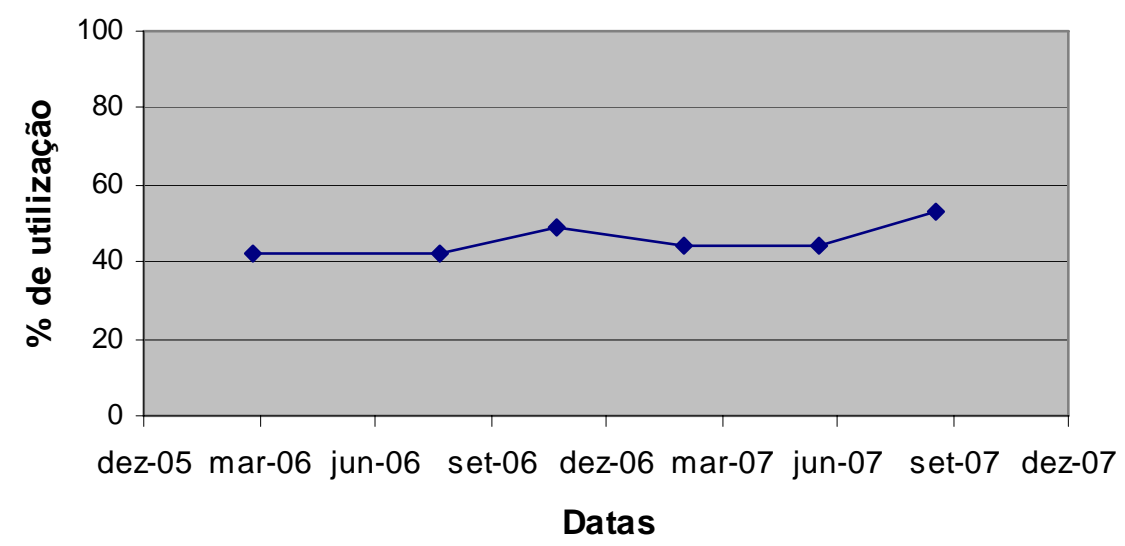

Figura 2. Utilização do rio Sanhauá para recreação de contato primário, contato secundário ou navegação. 
De acordo com a Figura 3, constata-se um percentual de utilização das águas do rio Sanhauá variando na faixa 20-70\% para pesca ou coleta de mariscos ou captura de crustáceos. O percentual médio para esses usos foi de 50,2\%.

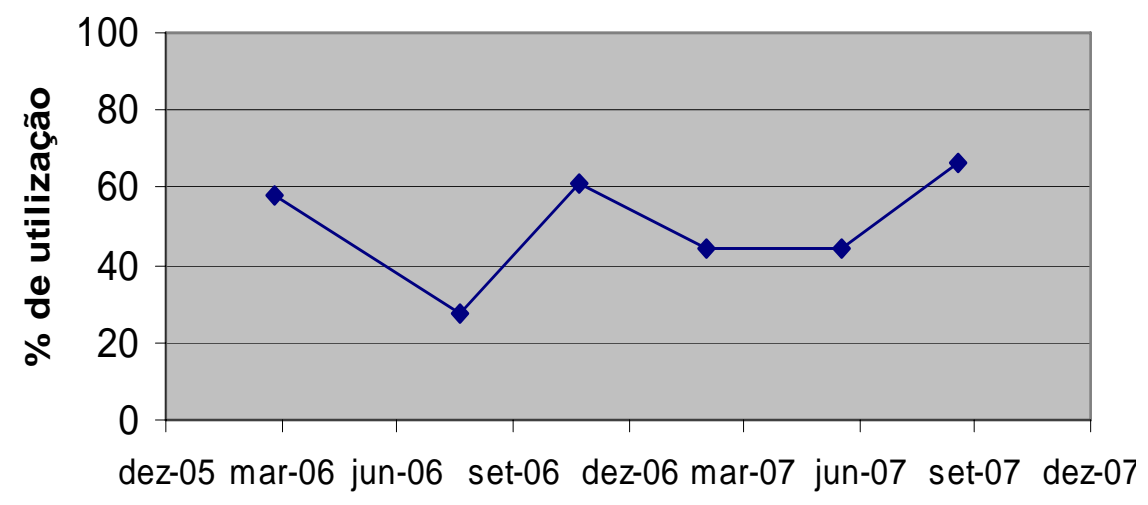

Datas

Figura 3. Utilização do rio Sanhauá para pesca ou coleta de mariscos ou captura de crustáceos.

Em média, 93,12\% dos entrevistados responderam que o seu domicílio não é atendido por serviço público de esgotamento sanitário (Figura 4) e com isso o destino final dos esgotos é o rio Sanhauá, ocorrendo de forma direta ou indireta através de galeria de água pluvial, causando prejuízos aos outros usos da água.

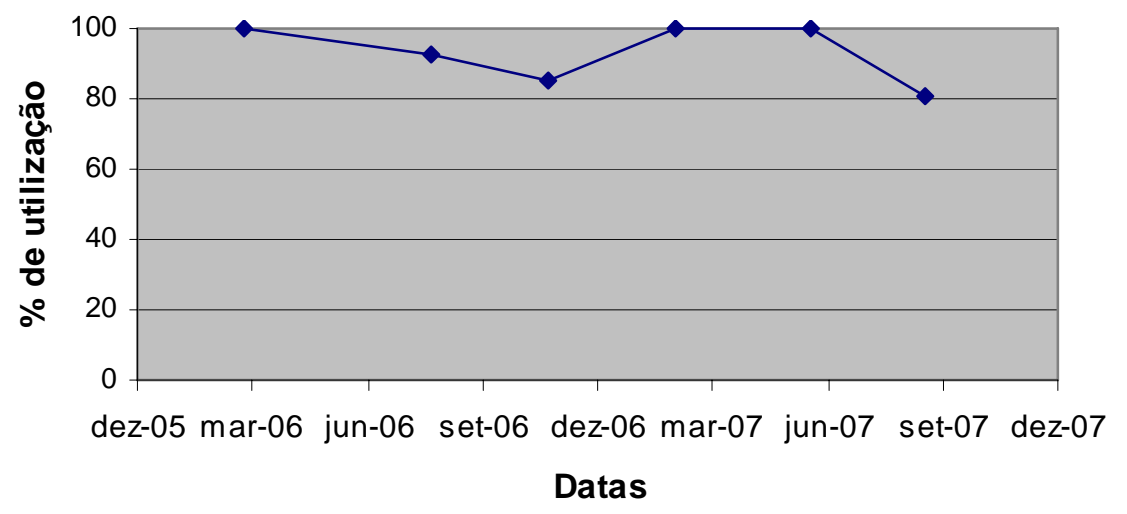

Figura 4. Lançamento de esgoto doméstico no rio Sanhauá (para as localidades estudadas).

Com base nos questionários aplicados aos moradores do Porto do Capim, da favela do "S" e do entorno do antigo lixão do Roger, observa-se que mesmo essas áreas sendo atendidas por serviço de coleta de resíduos sólidos ainda existem pessoas que fazem uso do rio Sanhauá para despejo de lixo, provocando conflitos e indisponibilizando a água para outras finalidades. Na Figura 5, pode-se perceber que um percentual variando entre 20 e $60 \%$ dos entrevistados declararam ter conhecimento de despejo de resíduos sólidos no rio Sanhauá. 


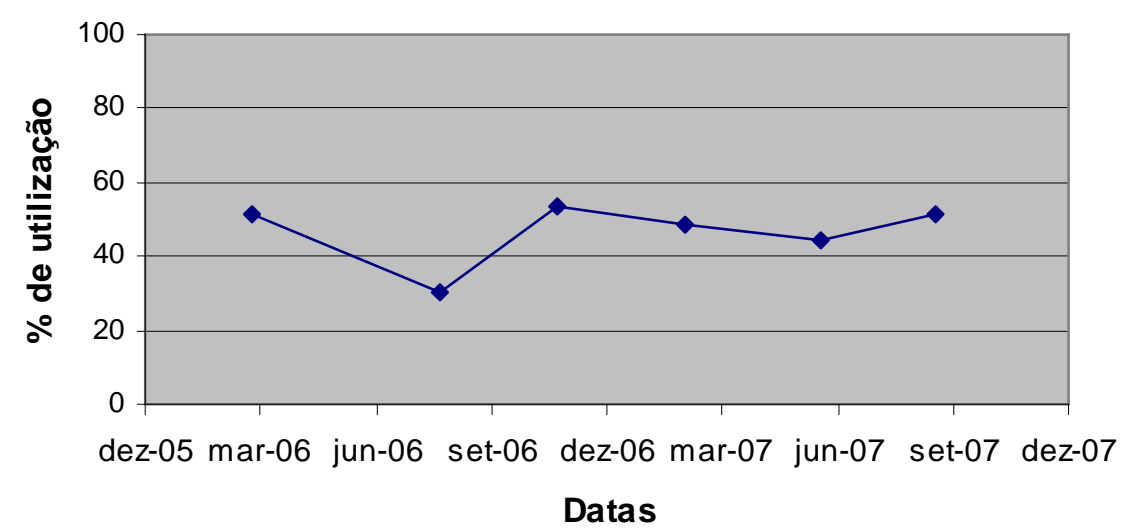

Figura 5. Conhecimento de despejo de resíduos sólidos.

De acordo com a Figura 6 constata-se que nas primeiras campanhas realizadas, nenhum dos entrevistados respondeu que utiliza a água do rio Sanhauá para uso no domicílio, entretanto na última inspeção uma pequena parcela das pessoas entrevistadas $(2,13 \%)$ respondeu que faz uso doméstico da água do Rio Sanhauá.

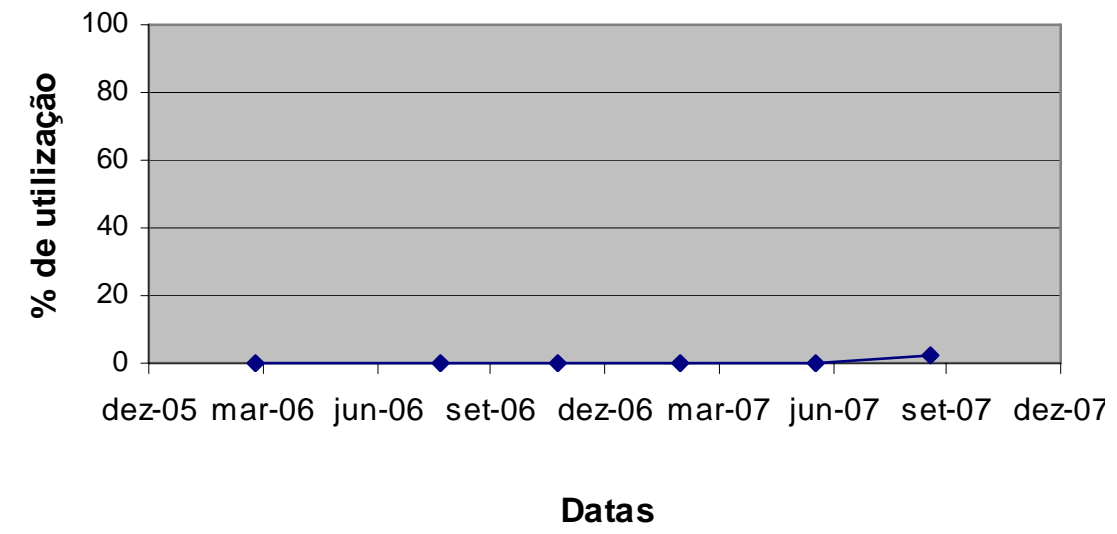

Figura 6. Utilização do rio Sanhauá para uso no domicílio.

\subsection{Monitoramento da qualidade da água no rio Sanhauá}

De acordo com a Superintendência de Administração do Meio Ambiente do Estado da Paraíba (SUDEMA, 1988), o rio Sanhauá está classificado como Classe 3 (água doce), baseando-se na antiga Resolução CONAMA No 20/1986 (Brasil, 1986). Entretanto, segundo essa última Resolução, bem como na Resolução CONAMA No 357/2005, que alterou a anterior, águas com salinidade igual ou inferior a 0,5\%o são consideradas como água doce e águas com salinidade entre $0,5 \%$ e $30 \%$ como água salobra. De acordo com as amostras de água superficial coletadas nos pontos P1, P2, P3 e P4, verificou-se que esses pontos apresentaram valores de cloretos nesta última faixa (Figura 12). Verificou-se, também, a presença de manguezais no rio, ecossistemas estes que são característicos de águas salobras, não ocorrendo o aparecimento deles em águas doces e, além do fato de o rio situar-se numa área que sofre influência da maré (região estuarina). Portanto as águas do rio Sanhauá no trecho considerado são salobras e não doces.

Segundo a Resolução CONAMA N $357 / 2005$ e os usos preponderantes da água verificados no rio Sanhauá (recreação, navegação, pesca, captura e coleta de mariscos ou crustáceos, lançamento de esgoto doméstico, despejos de resíduos sólidos), percebe-se que as águas deste se enquadrariam na Classe 1 de água salobra. 
A seguir são apresentados os resultados das análises físico-químicas e microbiológicas realizadas nas amostras de água superficial, coletadas num córrego no manguezal afluente ao rio Sanhauá (pontos P1 e P2) e no próprio rio Sanhauá (pontos P3 e P4), além do correspondente valor máximo permitido (VMP) pela resolução CONAMA No 357/2005 para água salobra classe 1 (no caso do oxigênio dissolvido VMP é o valor mínimo permitido).

Observa-se que em quase todas as inspeções realizadas os pontos de coleta apresentaram valores de OD abaixo de $5 \mathrm{mg} / \mathrm{L}$ (Figura 7), estando, portanto em desacordo com o padrão de qualidade da água da Resolução CONAMA Nº 357/2005 para água salobra de Classe 1.

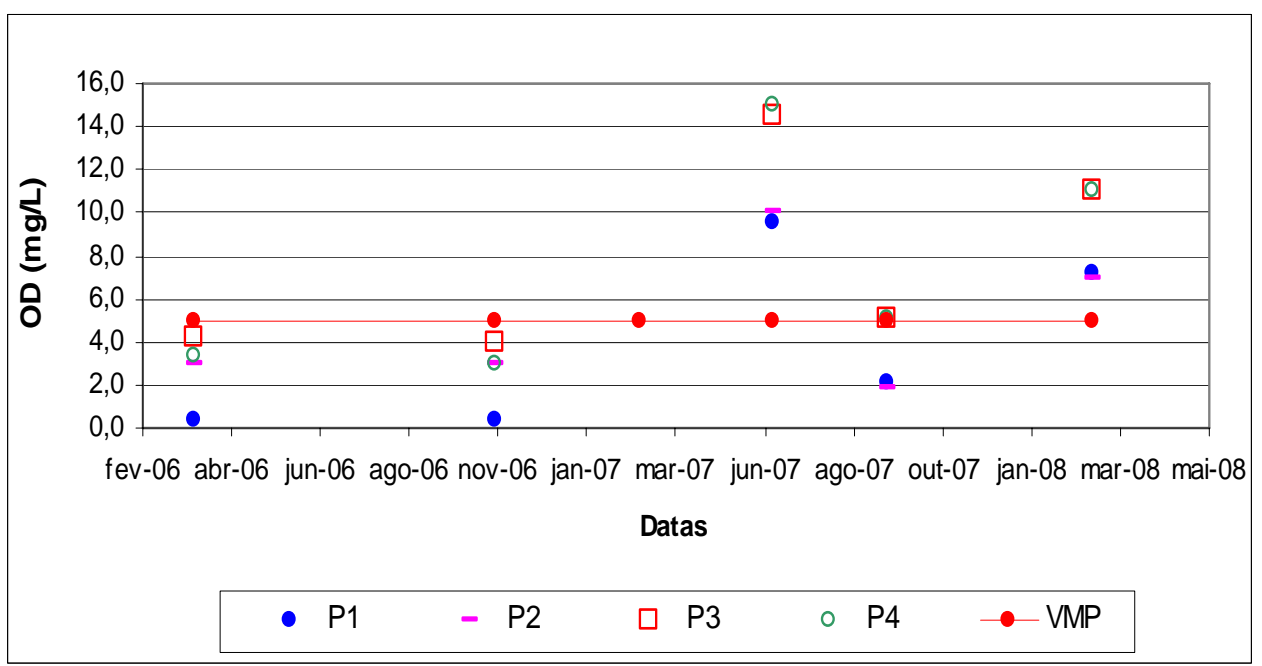

Figura 7. Variação temporal de OD (mg/L).

Segundo a Resolução CONAMA No 357/2005, o valor máximo permissível do parâmetro alumínio para água salobra de classe 1 é de $0,1 \mathrm{mg} / \mathrm{L}$, mas de acordo com a Figura 8, os valores para este parâmetro estiveram acima desse valor.

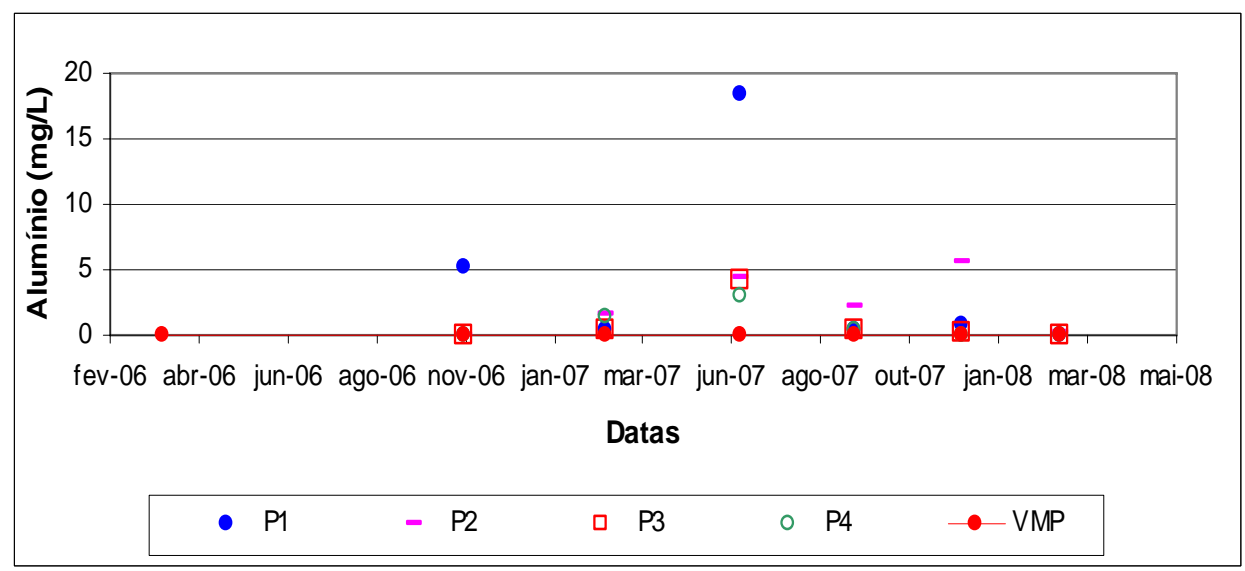

Figura 8. Variação temporal de Alumínio (mg/L).

Em relação à concentração de chumbo, verifica-se (Figura 9) que em todos os pontos prevalecem valores superiores ao valor máximo permissível da Resolução citada (0,01 mg/L). 
ATHAYDE JÚNIOR, G. B.; NÓBREGA, C. C.; GADELHA, C. L. M.; SANTANA, N. C. B.; COSTA, M. D. Principais usos da água do rio Sanhauá na área de influência do antigo lixão do Roger: proposta de revisão de enquadramento do rio. Ambi-Agua, Taubaté, v. 3, n. 3, p. 128-142, 2008. (doi:10.4136/ambi-agua.67)

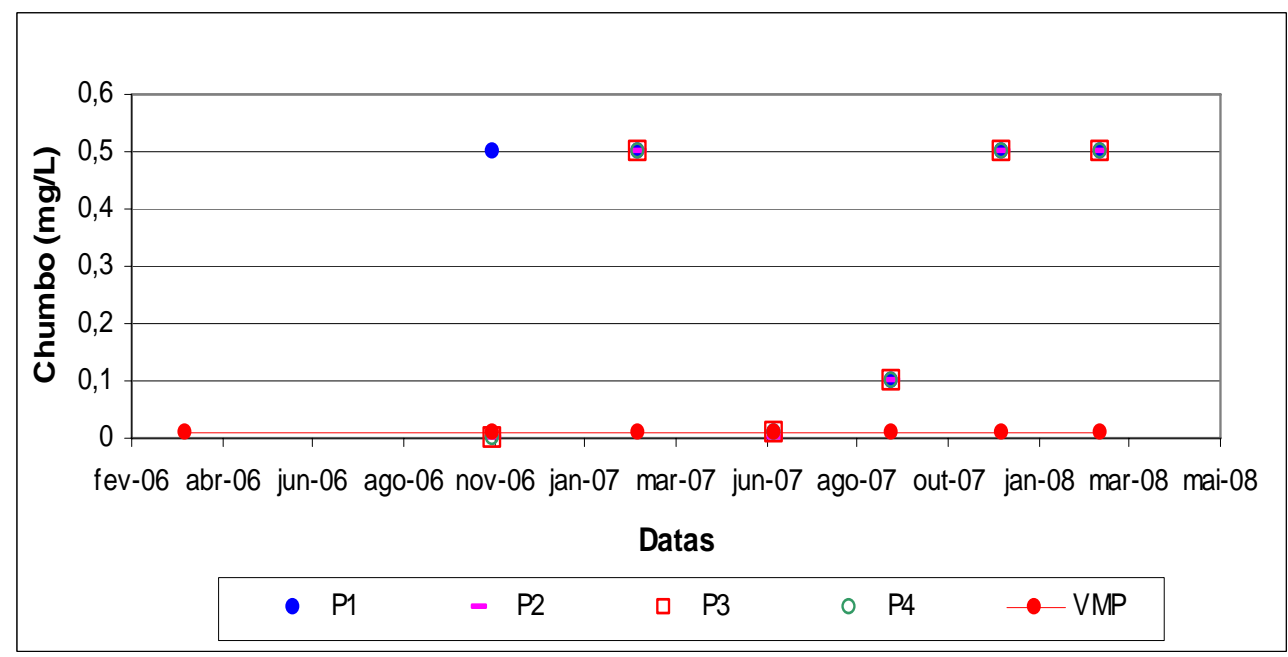

Figura 9. Variação temporal de Chumbo (mg/L).

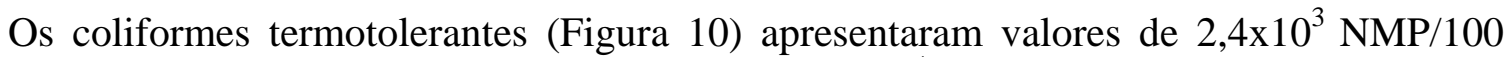
$\mathrm{mL}$, com exceção do ponto P1 na terceira coleta $\left(2,3 \times 10^{4} \mathrm{NMP} / 100 \mathrm{~mL}\right)$ e do ponto P2 na última coleta $\left(4,6 \times 10^{2} \mathrm{NMP} / 100 \mathrm{~mL}\right)$, e, portanto, estando em desacordo com os padrões de qualidade da água estabelecidos para águas salobras classe 1.

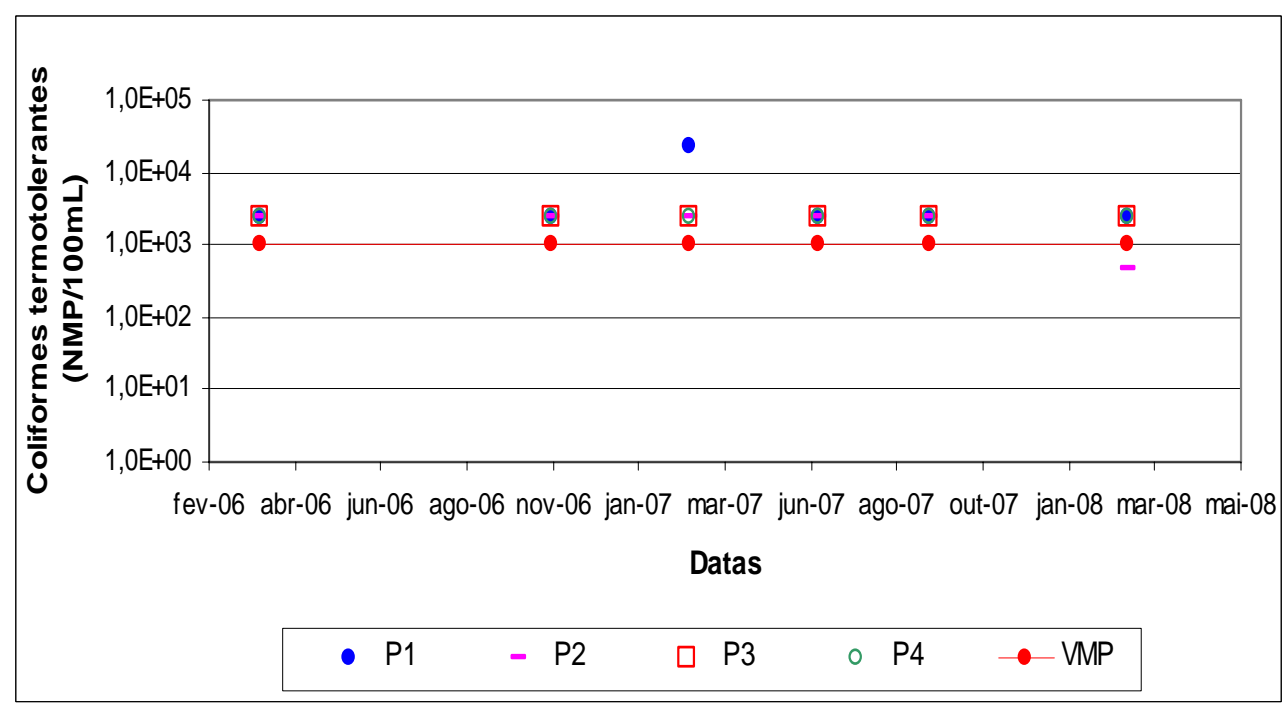

Figura 10. Variação temporal de Coliformes termotolerantes (NMP/100 ml).

Em relação ao parâmetro nitrato, observa-se que (Figura 11) na terceira campanha de coleta apenas o ponto P2 apresentou valor acima de $0,40 \mathrm{mg} / \mathrm{L}$ (VMP) e na quarta campanha todos os pontos apresentaram valores superiores ao valor máximo permissível.

Observa-se ainda que em todas as campanhas realizadas e em todos os pontos os valores de cloretos estiveram entre 5000 e 25000 mg/L (Figura 12). 


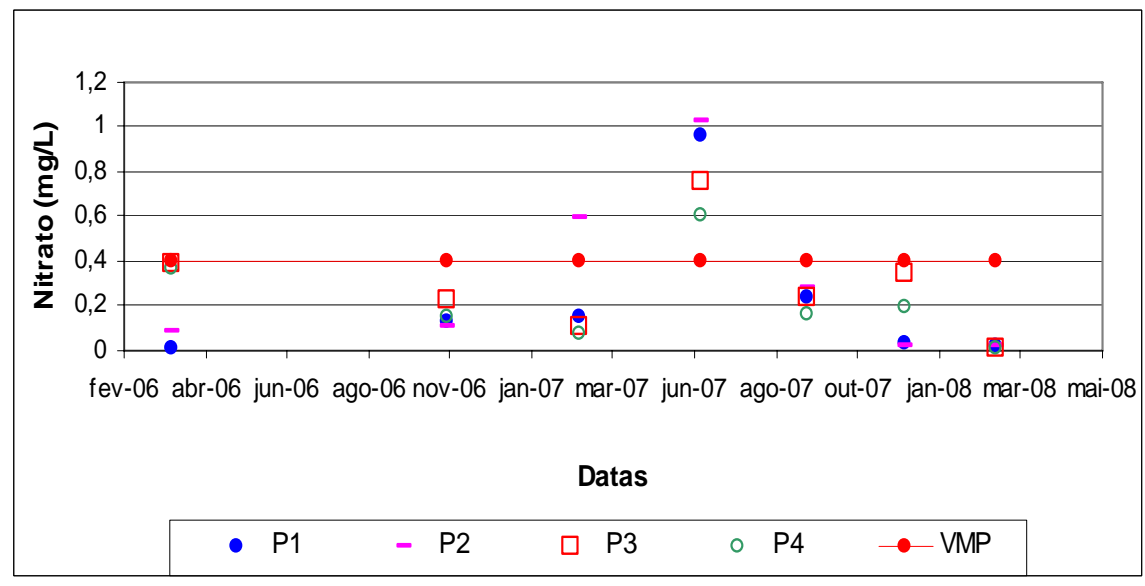

Figura 11. Variação temporal de Nitrato (mg/L).

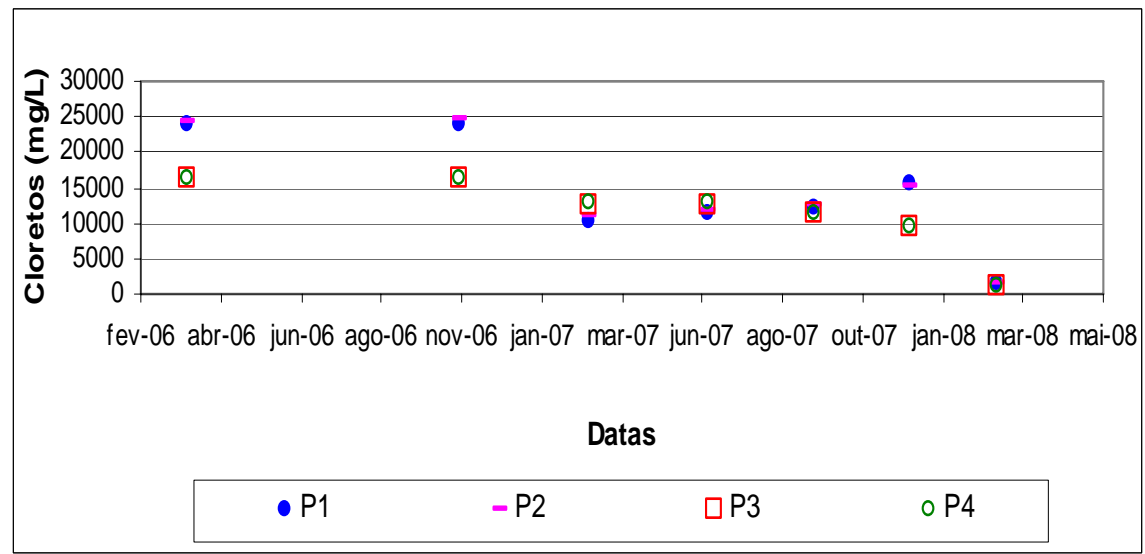

Figura 12. Variação temporal de Cloretos (mg/L).

De acordo com o monitoramento realizado, a qualidade da água do rio Sanhauá, no trecho considerado, não satisfaz aos padrões estabelecidos na Resolução CONAMA N ${ }^{\circ}$ 357/2005 para água salobra classe 1. Faz-se necessário, portanto, a intervenção do Poder Público para tomar medidas e ações no sentido de que o rio Sanhauá passe a ser definido como de água salobra e classificado como Classe 1 e que apresente a qualidade requerida da classe da qual seus usos necessitam.

\section{CONCLUSÃO}

O antigo lixão do Roger continua sendo um dos problemas de degradação e poluição do Rio Sanhauá, mas é preciso atentar que as ações antrópicas principalmente na área do manguezal e na porção estuarina do rio como recreação, navegação, pesca, captura e coleta de mariscos ou crustáceos, lançamento de esgoto doméstico, despejos de resíduos sólidos e uso domiciliar são conflitantes entre si e contribuem para a poluição do rio.

Segundo os usos das águas verificados no rio Sanhauá, sua salinidade e a Resolução CONAMA No 357/2005, o enquadramento desse rio seria de água salobra de Classe 1 . Porém, de acordo com o monitoramento realizado nos pontos P1, P2, P3 e P4, verificou-se que a qualidade da água não satisfaz os padrões de qualidade estabelecidos na referida Resolução CONAMA para essa classe. Faz-se necessário, portanto, a adoção de medidas por parte do poder público no sentido de compatibilizar os usos existentes com a qualidade da água do rio ou a revisão do enquadramento do corpo aquático em benefício da saúde da população local. 


\section{REFERÊNCIAS}

AMERICAN PUBLIC HEALTH ASSOCIATION (APHA). Standard methods for the examination of water and wastewater. 20. ed. New York: Public Health Association, 1998.

BASSOI, L. J.; GUAZELLI, M. R. Controle Ambiental da água. In: PHILIPPI Jr, A.; ROMÉRO, M. de A.; BRUNA, G. C. Curso de gestão ambiental. Barueri: Manole, 2004. p. 53-99.

BRASIL. Lei $\mathrm{n}^{\circ}$ 6938, de 31 de agosto de 1981. Dispõe sobre a Política Nacional do Meio Ambiente, seus fins e mecanismos de formulação e aplicação, e dá outras providências. Diário Oficial [da] República Federativa do Brasil. Brasília, 02 set. 1981.

BRASIL. Lei n. 9433, de 08 de janeiro de 1997. Institui a Política Nacional de Recursos Hídricos, cria o Sistema Nacional de Gerenciamento de Recursos Hídricos, regulamenta o inciso XIX do art. 21 da Constituição Federal, e altera o art. $1^{\circ}$ da Lei $n^{\circ} 8.001$, de 13 de março de 1990, que modificou a Lei ${ }^{\circ}$ 7.990, de 28 de dezembro de 1989. Diário Oficial [da] República Federativa do Brasil. Brasília, 09 jan. 1997.

BRASIL. Resolução CONAMA N 20, de 18 de junho de 1986. Dispõe sobre a classificação dos corpos de água e diretrizes ambientais para o seu enquadramento, bem como estabelece as condições e padrões de lançamento de efluentes, e dá outras providências. Diário Oficial [da] República Federativa do Brasil. Brasília, 30 julho 1986.

BRASIL. Resolução CNRH n¹2, de 19 de julho de 2000a. Dispõe sobre procedimentos para enquadramentos dos corpos aquáticos. Diário Oficial [da] República Federativa do Brasil. Brasília, 20 julho de 2000.

BRASIL. Resolução CONAMA no 274, de 29 de novembro de 2000b. Revisa os critérios de balneabilidade em águas brasileiras. Disponível em: <http://www.mma.gov.br>. Acesso em: 15 jun. 2007.

BRASIL. Resolução CONAMA $\mathbf{n}^{0}$ 357, de 17 de março de 2005. Dispõe sobre a classificação dos corpos de água e diretrizes ambientais para o seu enquadramento, bem como estabelece as condições e padrões de lançamento de efluentes, e dá outras providências. Disponível em: <http://www.mma.gov.br>. Acesso em: 15 jun. 2007.

CAMERON, W. M.; PRITCHARD, D. W. Estuaries. In: The sea - 2. London: WileyInterscience, 1963. . p. 306-324.

DIAS, I. C. S. Estudo da viabilidade técnica, econômica e social do aproveitamento de água de chuva em residência na cidade de João Pessoa. 2007. 116f. Dissertação (Mestrado em Engenharia Urbana) - Universidade Federal da Paraíba, João Pessoa, 2007.

EMLUR. Cadastro dos catadores do Lixão do Roger. João Pessoa: EMLUR, 2003.

INSTITUTO BRASILEIRO GEOGRAFIA E ESTATÍSTICA - IBGE. Pesquisa nacional de saneamento básico. Rio de Janeiro: IBGE, 2000.

INTERSAT. Imagem Landsat7/ETM ${ }^{+}$em 04/08/2001. 2001. Disponível em: <www.intersat.com.br>. Acesso em: 15 jul. 2007.

MARTÍNEZ, S. G.; SOTO, C. A. V. Tratamiento de los lixiviados de un vertedero en un sistema de lodos activados. In: CONGRESO INTERAMERICANO DE INGENIERIA 
SANITARIA Y AMBIENTAL, 27., Porto Alegre, 2000. Anais... Porto Alegre: AIDIS, 2000.

PESSIN, N.; BRUSTOLIN, I.; FINKLER, R. Determinação da eficiência de tratabilidade de reatores biológicos para atenuação de carga orgânica presente no chorume proveniente de aterros sanitários. In: SIMPÓSIO LUSO-BRASILEIRO DE ENGENHARIA SANITÁRIA E AMBIENTAL, 9., Porto Seguro, 2000. Anais... Porto Seguro: Associação Brasileira de Engenharia Sanitária e Ambiental, 2000. p 1496-1503.

QUEIRÓZ, S. M. P. Avaliação de Impactos Ambientais: Conceitos, Definições e Objetivos. In: JUCHEM, P. A. (Coord.). Manual de avaliação de impactos ambientais. Curitiba: SUREHMA/GTZ, 1993. p. 1-11.

RUSSO, M. A. T.; FERREIRA, M.; VIEIRA, C. Caracterização de aterros sanitários de alta compactação. In: SIMPÓSIO LUSO-BRASILEIRO DE ENGENHARIA SANITÁRIA E AMBIENTAL, 9., Porto Seguro, 2000. Anais... Porto Seguro: Associação Brasileira de Engenharia Sanitária e Ambiental, 2000. p 1789-1798.

SEGATO, L. M.; DA SILVA, C. L. Caracterização do chorume do aterro sanitário de Bauru. In: CONGRESSO INTERAMERICANO DE INGENIERIA SANITARIA Y AMBIENTAL, 27., Porto Alegre, 2000. Anais... Porto Alegre: AIDIS, 2000.

SHIKLOMANOV, A. World water resources and their use. UNESCO. 1999. Disponível em: $\quad<$ http://webworld.unesco.org/water/ihp/db/shiklomanov/ summary/html/sum_tab8.html>. Acesso em: 28 jan. 2008.

SOARES, P. F.; LISOT, A. Manual de projeto e análise de desempenho de redes de monitoramento da qualidade da água. Brasília: ANA, 2007.

SUPERINTENDÊNCIA DE ADMINISTRAÇÃO DO MEIO AMBIENTE - SUDEMA. Sistema Estadual de Licenciamento de atividades poluidoras - SELAP. DZS 205: Enquadramento dos corpos d’águas da bacia hidrográfica do rio Paraíba. . João Pessoa: SUDEMA, 1988.

VASCONCELOS, I. C. D.; ATHAYDE JÚNIOR, G. B.; GADELHA, C. L. M.; SANTOS, A. B. Água e poluição. In: ATHAYDE JÚNIOR, G. B.; Santos, A. B. Qualidade da água e controle da poluição. Salvador: Secretaria Nacional de Saneamento Ambiental/RECESA, 2008. 


ISSN = 1980-993X-doi:10.4136/1980-993X
www.agro.unitau.br/ambi-agua
E-mail: ambi-agua@agro.unitau.br
Tel.: (12) 3625-4116

\title{
Protocolos de avaliação rápida de rios e a inserção da sociedade no monitoramento dos recursos hídricos
}

(doi:10.4136/ambi-agua.68)

\author{
Aline Sueli de Lima Rodrigues ${ }^{1}$; Guilherme Malafaia²; Paulo de Tarso Amorim \\ Castro $^{3}$ \\ Universidade Federal de Ouro Preto-MG, Rua Vereador Paulo Elias, n. 8A - Vila Itacolomy, Ouro Preto- \\ MG, CEP 35400-000, Brasil \\ E-mail: ${ }^{1}$ aline@degeo.ufop.br; ${ }^{2}$ guilherme@nupeb.ufop.br; ${ }^{3}$ paulo_de_tarso@degeo.ufop.br
}

\section{RESUMO}

A degradação dos recursos hídricos tem sido detectada e mudanças, tanto institucionais quando legislativas, têm sido requeridas. $\mathrm{O}$ uso indiscriminado dos rios provoca mudanças ecológicas, causando sérias modificações na paisagem e no regime fluvial, além de alterar a disponibilidade dos habitats e a composição trófica do ambiente aquático. Em virtude desse cenário, os cientistas têm sido pressionados a desenvolver métodos de avaliação que sejam eficientes tanto em nível da própria avaliação, quanto como auxiliares nas tomadas de decisão nos processos de gerenciamento ambiental. Nessa perspectiva, o objetivo deste trabalho é apresentar os Protocolos de Avaliação Rápida de Rios (PARs) e esclarecer as razões pelas quais esses protocolos podem promover a participação da comunidade no monitoramento dos recursos hídricos. Os PARs avaliam, de forma integrada, as características de um trecho de rio de acordo com o estado de conservação ou degradação do ambiente fluvial e suas principais características são a viabilidade econômica e a fácil aplicação. Em regiões com poucos recursos financeiros e grandes problemas de qualidade da água os PARs podem ser utilizados em programas de monitoramento ambiental. Por meio dos protocolos, a integração da comunidade no monitoramento dos recursos hídricos gera dados que representam a qualidade dos ecossistemas fluviais ao longo do tempo, sem que sejam necessários custos altos e profissionais especializados no assunto. Os PARs consistem em uma ferramenta simplificada, mas não simplista, de avaliação de rios, que incorporada aos procedimentos metodológicos adotados pelos órgãos gestores podem aproximar a sociedade civil da questão ambiental.

Palavras-chave: protocolos; rios; monitoramento dos recursos hídricos; avaliação ambiental; sociedade.

\section{Rivers rapid assessment protocols and insertion of society in monitoring of water resources}

\begin{abstract}
The degradation of water resources has been detected and changes both institutional and in the legislation have been demanded. The careless use of rivers has ecological changes as direct consequence, causing serious modifications in the landscape and fluvial regime, besides altering the availability of habitats and the trophic composition of the aquatic environment. Pressed by this scenario, scientists have been developing assessment methods that are efficient both for the evaluation itself and for supporting decision taking in the environmental management processes. In this perspective, the objective of this study is to present the Rapid
\end{abstract}


River Assessment Protocols (RAPs) and to emphasize how these protocols can promote the community participation in water resources monitoring. The RAPs can used to evaluate in an integrated form the characteristics of a river section according to the conservation or degradation condition of the fluvial environment and it is characterized by its economic viability and easy applicability. In regions with poor financial resources and serious problems of water quality, the RAPs can be used in environmental management programs. By using these protocols, the integration of the community in water resources monitoring generates data which represent the quality of fluvial ecosystems throughout time, without requesting high costs or specialized professionals. The RAPs in a simplified but not simplistic tool, which can be used in activities that aim at promoting a quick and reliable assessment of the "health" of a river.

Keywords: protocols; rivers; water resources monitoring; environmental assessment; society.

\section{INTRODUÇÃO}

Na década de 1960, ampliaram-se as preocupações com os limites do desenvolvimento, seus impactos negativos sobre a saúde humana e os níveis de degradação ambiental. Com o crescimento da população e conseqüente aumento da poluição e degradação dos corpos d’água existentes, a quantidade de água doce disponível para o uso humano e sua qualidade vêm diminuindo intensa e drasticamente (Tundisi, 2003). Segundo relatório da Organização das Nações Unidas (ONU), se medidas urgentes não forem tomadas para implementar o uso racional dos recursos hídricos, 60 países correspondendo a $75 \%$ da população mundial deverão sofrer com a falta de água no ano de 2050 (PNUD, 2003). De acordo com o Relatório de Desenvolvimento Humano $(\mathrm{RDH})$, divulgado pelo programa das Nações Unidas para o Desenvolvimento (PNUD), a falta de acesso à água e ao saneamento mata 1 criança a cada 19 segundos em decorrência de diarréia (PNUD, 2006).

Ao longo dos séculos, a ação humana tem provocado uma série de perturbações nos ecossistemas aquáticos. Historicamente, o uso das águas nunca foi realizado levando em consideração princípios de conservação (Trush et al., 2000; Barrella et al., 2001). A partir do século XVII e durante o século XVIII, observou-se o desenvolvimento da hidrologia e hidráulica, tendo como conseqüência direta o aumento dos impactos deletérios sobre os cursos d’água. No final do século XVIII, a forte intervenção da engenharia fluvial na paisagem foi observada em grandes proporções e, em meados do século XIX, a maioria dos rios europeus já tinha sido canalizada ou retificada (Saraiva, 1999; Silva et al., 2006). Nessa mesma época, iniciaram-se os estudos sobre águas interiores, contudo estes se concentravam apenas nos lagos. Em meados do século XX, os estudos passaram a ter como foco os rios, porém com uma abordagem basicamente hidrológica com fins econômicos, destacando-se a construção de barragens para a obtenção de energia elétrica, construção de eclusas e retificação de cursos para a navegação e estudos sobre saneamento em regiões criticamente poluídas. Já os estudos de abordagem ecológica surgiram logo após esse período e, atualmente, algumas pesquisas têm buscado uma abordagem global e interativa dos processos envolvidos na bacia hidrográfica (Schwarzbold, 2000).

No Brasil, o monitoramento da qualidade da água aparece na legislação federal na década de 1970, por meio da Portaria GM-0013 de 15 de janeiro de 1976 da Secretaria Especial do Meio Ambiente (SEMA), que estabeleceu uma das primeiras classificações para os corpos d'água superficiais, com os respectivos padrões de qualidade e de emissão de efluentes associados a classes de uso preponderante (Brasil, 1976). No que tange aos 
fundamentos legais da participação social no monitoramento e gestão dos recursos hídricos, nos últimos 20 anos foi possível perceber avanços importantes no setor dos recursos hídricos (Dagnino, 1994; Santos e Avritzer, 2002; Jacobi, 2003), e a mudança de uma gestão institucionalmente fragmentada para uma legislação integrada e descentralizada, aparece na edição da Lei das Águas (Brasil, 1997), considerada um dos avanços mais significativos observados nestes últimos anos.

A Lei das Águas instituiu a Política Nacional de Recursos Hídricos e criou o Sistema Nacional de Gerenciamento de Recursos Hídricos (SIGRH), incorporando os princípios estabelecidos durante a Conferência de Dublin em 1992, os quais defendem que a sociedade tem papel essencial na proteção dos ecossistemas naturais. De acordo com essa Conferência, a participação social é fundamental para o sucesso do monitoramento e gerenciamento dos recursos hídricos, pois quando a sociedade tem consciência da importância da conservação do meio ambiente, o gerenciamento é facilitado.

Além disto, há de se destacar que a Lei das Águas propõe um modelo de gestão dos recursos hídricos baseado no fortalecimento das relações entre o Poder Público e a sociedade civil, conforme disposto no capítulo I, art. $1^{\circ}$, inciso VI: "a gestão dos recursos hídricos deve ser descentralizada e contar com a participação do Poder Público, dos usuários e das comunidades”. A lei permite que o Poder Público estabeleça parceria com os usuários da água e com a sociedade civil organizada.

Bons exemplos de como podem ser estabelecidas as parcerias entre o Poder Público e a sociedade civil organizada são os Comitês de Bacias Hidrográficas (CBHs) que em 2007, contabilizaram 132 Comitês Estaduais, 7 Federais e 29 Consórcios Intermunicipais (REBOB, 2007). Os CBHs estão baseados justamente no tripé descentralização, participação e integração tendo como ênfase uma política participativa e um processo decisório aberto aos diferentes atores sociais vinculados ao uso da água, nos quais se revêem as atribuições do Estado, o papel dos usuários e o próprio uso da água. Conforme discutido por Jacobi e Barbi (2007), os atores envolvidos tendem a atuar baseados em um referencial sobre seu papel, responsabilidades e atribuições, neutralizando dessa forma, práticas predatórias orientadas pelo interesse econômico ou político. Isso facilita uma interação mais transparente e permeável no relacionamento entre os diferentes atores envolvidos - governamentais, empresariais e usuários - e limita as chances de abuso do poder (Jacobi, 2004).

Sem dúvidas, essa reorganização da gestão dos recursos hídricos substituiu práticas profundamente arraigadas de planejamento tecnocrático e autoritário. Devolve-se o poder para as instituições descentralizadas de bacia, e isso implica promover processos de negociação entre os diversos agentes públicos, usuários e sociedade civil organizada. Porém, apesar dos instrumentos legais criados, o grande desafio para o monitoramento e gestão dos recursos hídricos ainda consiste em promover uma aproximação maior entre os órgãos responsáveis pela manutenção desses recursos e a sociedade (Del Prette, 2000), embora os mecanismos de participação tenham aumentado nos últimos 10 anos (Jacobi, 2005).

Para Buss (2002), é nítido que os tomadores de decisão, as agência ambientais e as comunidades não têm agido integradamente no monitoramento dos recursos hídricos. Para o autor, esse quadro se deve não apenas à falta de implementações práticas nessas áreas, mas também à dependência de análises com tecnologias dispendiosas e que cronicamente subestimam o grau de degradação dos recursos, impedindo a percepção da realidade ambiental. Além disto, há de se ressaltar que a má articulação entre os setores governamentais e sociais, bem como a falta de diagnósticos acurados sobre as condições sócio-ambientais das bacias hidrográficas têm sido, historicamente, um grave problema. A falta de informação sobre a quantidade e a qualidade dos ecossistemas aquáticos impede a sistematização de 
dados abrangentes, o que prejudica o desenvolvimento de políticas e planejamentos de ação para os recursos hídricos (Buss, 2002).

Numa análise mais acurada, pode-se notar que várias causas podem ser apontadas para explicar essas situações, estando, de um lado, os planos político, social e econômico e, de outro, o distanciamento existente entre os conhecimentos gerados nas instituições de ensino e pesquisa e as informações que chegam às comunidades da região.

Há veemente necessidade de estabelecimento de métodos de avaliação dos cursos d'água que sejam eficientes tanto em nível da própria avaliação, como auxiliares nas tomadas de decisões nos processos de gestão ambiental e/ou como instrumento que agregue os aspectos participativos no monitoramento dos recursos hídricos. Os problemas nos dados de qualidade da água disponíveis e as deficiências das redes de monitoramento têm levado muitos pesquisadores à reavaliarem os procedimentos comumente utilizados e a pensarem no estabelecimento de métodos úteis, eficazes e confiáveis que, em conjunto com os métodos já existentes, potencializem os dados referentes ao real estado dos recursos hídricos sob avaliação, com ajuda, é claro, das comunidades locais.

Nessa perspectiva, este trabalho, por meio de uma revisão sistematizada da literatura, tem por objetivo apresentar brevemente os Protocolos de Avaliação Rápida de Rios (PARs) e, sobretudo, esclarecer as razões pelas quais esses protocolos podem promover a inserção social no processo de monitoramento e gerenciamento dos ecossistemas fluviais.

\section{METODOLOGIA}

Utilizando materiais de fonte secundária, disponíveis na Biblioteca do Instituto de Ciências Exatas e Biológicas da Universidade Federal de Ouro Preto (UFOP) e no programa de comutação bibliográfica (COMUT), bem como no banco de dados SciELO (Scientific Eletronic Library Online) e Periódicos CAPES, foram selecionados trabalhos que abordaram os PARs e a questão da participação social na gestão ambiental. A pesquisa bibliográfica incluiu artigos originais, artigos de revisão, livros, anais de congresso, editoriais e diretrizes escritos nas línguas inglesa e portuguesa. Os seguintes termos de pesquisa (palavras-chaves e delimitadores) foram utilizados em várias combinações: 1) protocolos; 2) rios; 3) participação social; 4) gestão ambiental; 5) recursos hídricos; 6) avaliação rápida; 7) sociedade; 8) monitoramento; 9) bacia hidrográfica e 10) legislação ambiental.

Para a seleção dos artigos os seguintes critérios foram utilizados: i) artigos que trataram de métodos de avaliação e monitoramento dos recursos hídricos; ii) artigos que trataram da participação da sociedade nas questões ambientais, especialmente no monitoramento dos recursos hídricos; iii) procedência e idioma: artigos nacionais e internacionais publicados em revistas especializadas; iv) tipo de publicação: periódicos e iv) ano de publicação: 1976 a 2008.

\section{RESULTADOS E DISCUSSÃO}

\subsection{Protocolos de avaliação rápida de rios}

Os Protocolos de Avaliação Rápida de Rios (PARs), nascidos de estudos liderados pela Environmental Protection Agency (EPA), durante a década de 1980, em conjunto com agências de monitoramento de águas superficiais, são utilizados para caracterizar o rio qualitativamente. É estabelecido, em princípio, um limite considerado normal baseado em locais minimamente perturbados sendo estes tomados como "referência" (Plafkin et al., 1989), partindo da premissa de que os cursos d'água pouco afetados pela ação humana 
exibem condições biológicas mais favoráveis (Minatti-Ferreira e Beaumord, 2004, 2006). O gradiente de estresse ambiental é definido a partir da observação desses locais "referência" e de locais com vários graus de alterações, desde os pouco alterados até os muito degradados.

Por definição, os PARs são ferramentas que agregam indicadores de qualidade ambiental referentes aos aspectos físicos e biológicos do ecossistema fluvial, que podem ser usados como um instrumento de avaliação dos recursos hídricos. Os PARs constituem-se em documentos de referência que reúnem procedimentos metodológicos aplicáveis à avaliação rápida, qualitativa e semi-quantitativa, de um conjunto de variáveis representativas dos principais componentes e fatores geomórficos e sedimentológicos, que condicionam e controlam os processos e funções ecológicas dos sistemas fluviais (Rodrigues e Castro, 2008; Rodrigues et al., 2008).

Em alguns países, a avaliação dos recursos hídricos vem sendo realizada por meio dos PARs, a exemplo da Austrália, onde o programa criado pelo governo e denominado Australian River Assessment System (AusRivAS), utiliza protocolos de avaliação rápida no monitoramento da qualidade ambiental dos rios do país (Parsons et al., 2002). De forma análoga, o Rapid Bioassessment Protocols (RBP's) e o River Habitat Survey (RHS), respectivamente, das agências ambientais dos Estados Unidos e do Reino Unido, adotam uma avaliação visual rápida e qualitativa para caracterizar a qualidade física global do habitat (Barbour et al., 1999).

Segundo Resh e Jackson (1993), esses protocolos são análogos aos termômetros utilizados na avaliação da saúde humana, em que valores obtidos são comparados com o que se considera "normal". As pontuações atribuídas a cada um dos parâmetros avaliados indicam o estado de "saúde" do sistema.

Para exemplificar o uso da metodologia destaca-se o estudo desenvolvido por Rodrigues (2008) no interior do Parque Estadual do Itacolomi e arredores, no município de Ouro Preto MG. Tendo em vista a importância ecológica, econômica e social dos ambientes aquáticos continentais, bem como a necessidade da inclusão de fatores abrangentes e interativos na avaliação dos recursos hídricos que visam cobrir uma ampla gama de características do rio analisado, o estudo propôs um PAR que reuniu um conjunto de parâmetros de caráter geomorfológico, sedimentológico, ecológico e biológico. A Tabela 1 sumariza os parâmetros considerados nesse protocolo.

Para cada parâmetro neste PAR, foi atribuída uma pontuação entre 0 e 20 pontos, correspondente à condição ambiental do trecho de rio sob avaliação. Os valores são distribuídos de acordo com o gradiente de estresse ambiental verificado no local da avaliação, podendo variar desde uma condição considerada "ótima" (16 a 20 pontos), até uma condição "péssima" (0 a 5 pontos), passando por situações intermediárias "boa" (11 a 15 pontos) e "regular" (6 a 10 pontos).

A pontuação aumenta na mesma proporção da qualidade do habitat e pode variar de acordo com o local das observações. Para os parâmetros cuja avaliação envolve as margens do canal (esquerda e direita), como nos parâmetros 11, 12 e 13 (apresentados na Tabela 1), a pontuação foi atribuída a cada margem separadamente. Nesses casos, as margens poderão apresentar diferentes condições ambientais e a avaliação do trecho, com relação a esses parâmetros, é obtida pelo somatório das pontuações verificadas em cada uma das margens. Notas maiores refletem um bom estado de conservação, enquanto notas menores indicam que existe um estado de degradação severa. 
Tabela 1. Relação dos parâmetros propostos no protocolo de avaliação rápida de rios proposto por Rodrigues (2008).

\begin{tabular}{l}
\hline Parâmetros \\
\hline 1. Substratos e/ou habitats disponíveis \\
2. Substratos em poços \\
3. Soterramento \\
4. Regimes de velocidade/profundidade \\
5. Diversidade dos poços \\
6. Deposição de sedimentos \\
7. Condições de escoamento do canal \\
8. Alterações no canal \\
9. Sinuosidade do canal \\
10. Freqüência de corredeiras \\
11. Estabilidade das margens \\
12. Proteção das margens pela vegetação \\
13. Estado de conservação da vegetação do entorno \\
\hline
\end{tabular}

\subsection{A participação social no monitoramento dos recursos hídricos com base em protocolos de avaliação rápida}

O primeiro ponto positivo destacado nos PARs diz respeito aos agentes sociais que podem realizar o monitoramento. Em geral, não são necessários especialistas no assunto e o método pode ser estendido a pessoas de qualquer segmento social, bastando para isso um treinamento prévio ou instruções mínimas que os permitem aplicar o protocolo sem grandes divergências. De acordo com Resh et al. (1996) e Buss (2002), os programas de monitoramento, como os que envolvem os recursos hídricos, podem ser realizados por pessoas treinadas e informadas sobre conhecimentos locais em sua região e trechos da bacia hidrográfica onde vivem, utilizando para isto metodologias padronizadas e simplificadas.

Buss et al. (2003) acreditam que um aspecto fundamental a ser considerado em um programa de monitoramento de recursos hídricos é a habilidade em traduzir as informações obtidas tanto para os gestores ambientais quanto para o público em geral. Para os autores, em muitas vezes, a complexidade dos resultados dos métodos tradicionais de avaliação impede a interpretação pelo público leigo, tornando a informação restrita e, por isso, obscura. Ao contrário, os PARs são ferramentas que permitem a formação de grupos de monitores ambientais voluntários nas comunidades, que freqüentemente podem realizar o levantamento de dados com qualidade, que podem ser considerados nos programas oficiais de monitoramento.

Um exemplo disso foi observado no estudo de Upgren (2004), no qual um PAR foi desenvolvido para monitorar os efeitos da agropecuária e das práticas de conservação dos solos na qualidade da água e do sistema fluvial, nas nascentes do rio Araguaia, GO, em que se pôde concluir que a inserção da comunidade local na avaliação ambiental dos rios da região é possível e produz resultados confiáveis. Nesse estudo, os próprios fazendeiros da região, donos de terras que os rios percorrem, foram capazes de aplicar o PAR adaptado e realizar uma avaliação periódica dos trechos, promovendo o monitoramento dos recursos hídricos da região.

No trabalho de Callisto et al. (2002), desenvolvido em trechos de bacia no Parque Nacional da Serra do Cipó - MG e no Parque Nacional da Bocaína - RJ, foi possível verificar a facilidade da aplicação de um PAR adaptado para a avaliação da diversidade de habitats nesses trechos, por estudantes voluntários. Os autores constataram que, além de não haver 
diferença significativa entre o padrão de respostas obtidas de 50 estudantes voluntários treinados e 50 não treinados, o tempo gasto na aplicação do protocolo, em cada trecho de rio analisado, foi de apenas 20 a 30 minutos, o que de acordo com os autores, reflete um bom entendimento ou uma definição clara da metodologia utilizada na avaliação rápida de habitats, ainda que em ambos os grupos tenham ocorrido uma breve explicação sobre a estrutura e funcionamento de ecossistemas lóticos.

Ainda nessa perspectiva, Rodrigues (2008) adequou um PAR para trechos de rios inseridos em campos rupestres do Estado de Minas Gerais, por meio da participação efetiva de estudantes universitários, um segmento específico da comunidade. Na ocasião, a autora ofereceu no âmbito de sua pesquisa uma oficina de monitoramento ambiental da qual participaram 42 voluntários. A idéia da incorporação da oficina de monitoramento ambiental no delineamento da pesquisa desenvolvida por Rodrigues (2008) fundamentou-se não só no envolvimento de um segmento social no monitoramento dos recursos hídricos estudados, mas também na participação deste na construção/adequação de um instrumento de avaliação holística dos sistemas fluviais.

Já Guimarães et al. (2006), no âmbito do Projeto ambiental Pampulha Limpa (PPL, 2006), criado em 2003, trabalharam com a aplicação de um PAR por centenas de crianças com idade entre 11 e 13, de escolas localizadas na bacia hidrográfica da Pampulha, Belo Horizonte, MG. O objetivo do trabalho foi justamente desenvolver nas crianças uma sensibilização, conscientização e mobilização quanto aos problemas ecológicos da Lagoa da Pampulha e a importância do monitoramento desse recurso hídrico. Na ocasião, foram realizadas saídas de campo para locais que apresentavam condições ambientais distintas, de modo a permitir comparações. Os locais visitados foram a Lagoa da Pampulha, Parque das Mangabeiras e Serra do Cipó. O "Protocolo para avaliação da saúde de rios e lagoas modificado para jovens cientistas", adaptado do proposto por Callisto et al. (2002), foi aplicado pelos escolares durante as saídas de campo. Os resultados desse trabalho mostraram que o PAR utilizado enquadra-se no elenco de ferramentas de cunho sócio-ambiental que permite comparações, suscita discussões e sensibiliza os estudantes para que adquiram valores e posturas conservacionistas, além de ter destacado a praticidade do PAR e a facilidade dos agentes envolvidos em identificar melhor o ambiente estudado por meio do protocolo.

O fato de o método contribuir com a redução de custos na avaliação dos sistemas fluviais, já que as análises físico-químicas e bacteriológicas geralmente exigem gastos onerosos, é outro aspecto positivo dos PARs. A viabilidade justifica-se, pois uma vez estabelecido o protocolo, a aplicação deste não é dispendiosa, o que permite que uma vasta malha de pontos de monitoramento seja estabelecida. Além disso, os PARs permitem a realização de uma avaliação global sobre o ecossistema investigado, conforme já discutido.

Em regiões com poucos recursos financeiros e grandes problemas de qualidade da água, por exemplo, os PARs podem ser utilizados em programas de monitoramento que envolvam a participação direta das comunidades, na tentativa de avaliar as condições básicas dos recursos hídricos em regiões onde a economia é empecilho para o desenvolvimento de projetos de monitoramento ambiental.

A integração da comunidade no monitoramento dos recursos hídricos, por meio dos PARs, gera dados que representam a qualidade dos ecossistemas fluviais ao longo do tempo, sem que sejam necessários custos altos e profissionais especializados no assunto. Esses dados podem ser úteis por detectarem possíveis interferências antrópicas sobre as fontes de água da região, além de gerarem uma consciência ambiental nas pessoas, despertando-as para a importância da manutenção dos recursos hídricos a elas disponíveis. 
Como o fortalecimento das bases sociais, no processo de gestão dos recursos hídricos (fiscalização e conservação dos recursos naturais), dar-se-á consensualmente por meio de agentes envolvidos no âmbito das bacias hidrográficas e por conteúdos metodológicos e programáticos de custos econômicos compatíveis à realidade financeira dos municípios (Garcia e Valencio, 2003; Jacobi, 2004), os dados coletados pela comunidade por meio dos PARs, podem assessorar os CBHs na condução eficaz do processo de fiscalização e gestão do patrimônio ambiental, já que os próprios agentes usuários dos recursos hídricos monitoram as condições destes.

Segundo Hannaford et al. (1997), as informações obtidas por meio dos PARs no âmbito de programas de monitoramento dos recursos hídricos, podem ser úteis para (i) sensibilizar para questões de preservação desses recursos, motivando a participação e inserção de comunidades no contexto social, político e econômico; (ii) oferecer um alerta imediato quando da ocorrência de acidentes ambientais (p.ex. derramamentos e fontes pontuais de poluição antrópica) e mortandade de peixes, contribuindo para medidas mitigadoras imediatas dos órgãos competentes e (iii) desenvolver técnicas e métodos de fácil aplicação para o desenvolvimento de programas de biomonitoramento, possibilitando a replicação da metodologia em outras sub-bacias em uma mesma região geográfica, por pessoas treinadas (não necessariamente especialistas no assunto).

Além disso, os PARs podem ser aplicados em pesquisas que exigem a obtenção de resultados rápidos, tais como em decisões de gerenciamento, podendo facilitar a transferência de conhecimento tanto para os gerenciadores quanto para a comunidade local. Podem ainda fornecer dados de vários locais para pesquisas de campo, podendo ser aplicados no desenvolvimento de metodologias em prol da conservação ambiental (Silveira, 2004).

O quadro abaixo resume de modo esquemático como os PARs podem inserir a sociedade civil nos processos de monitoramento e gestão dos recursos hídricos e aproximá-la do Poder Público (Fig. 1).

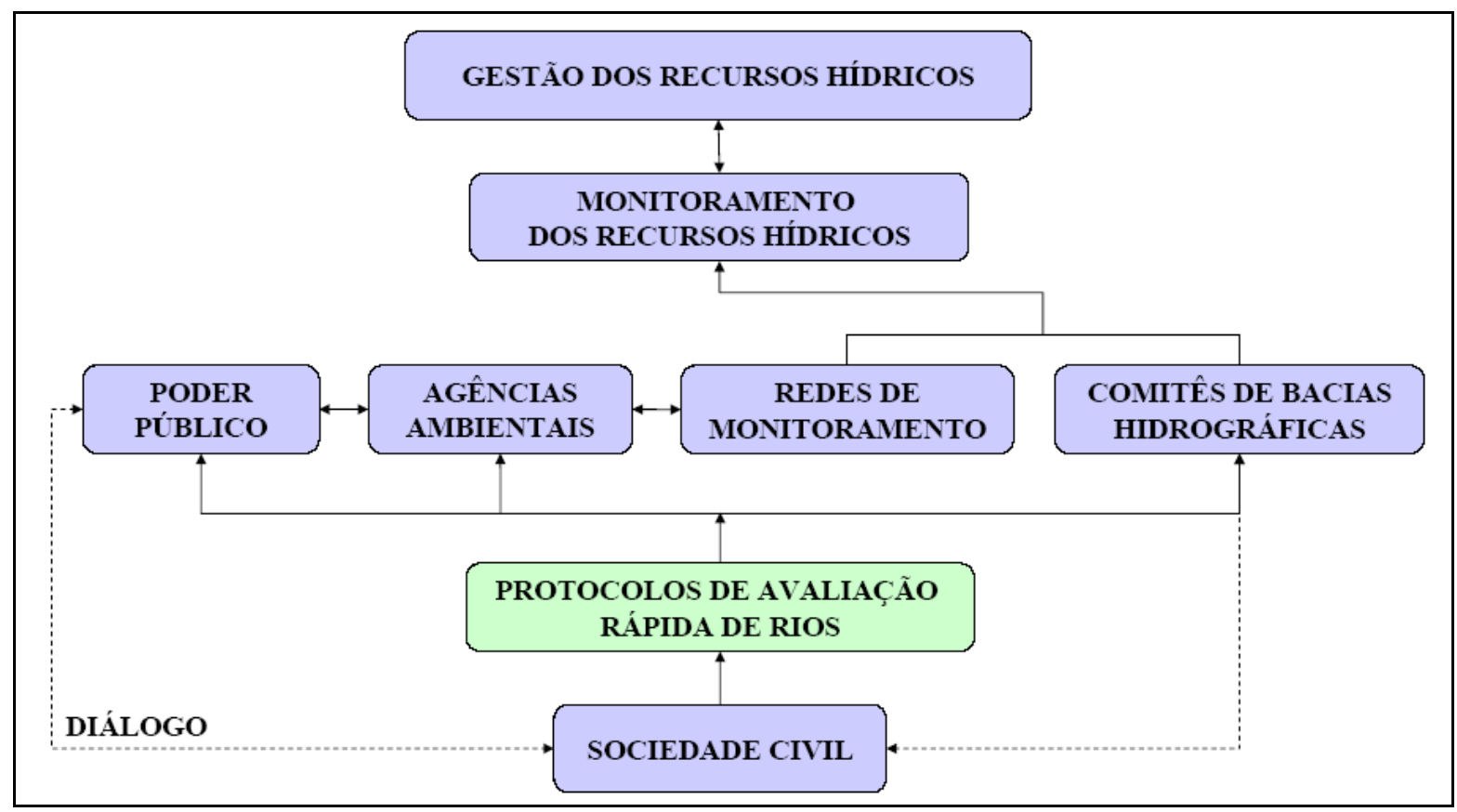

Figura 1. Fluxograma da participação social por meio dos Protocolos de Avaliação Rápida de Rios (PARs) na gestão dos recursos hídricos. 
Um exemplo de como os dados originados das aplicações dos PARs em diferentes trechos de rios poderiam contribuir para a evolução das políticas ambientais, é justamente a inclusão da metodologia proposta pelos protocolos em programas já implantados.

No Brasil, a Embrapa Meio Ambiente iniciou em 1999, um trabalho cujo objetivo é justamente incorporar a comunidade no monitoramento da qualidade da água, tendo treinado até o final do ano de 2002, cerca de 600 agentes voluntários, sendo 375 na bacia do Rio São Francisco (EMBRAPA, 2003). Em 2004, a Embrapa estruturou o Programa de Formação de Agentes Ambientais Voluntários em Monitoramento da Qualidade das Águas, o qual tem como objetivo a formação de uma rede de agentes de água que permita avaliação da qualidade dos recursos hídricos em toda a região do Submédio São Francisco. Equipamentos manuais de medição para a avaliação da qualidade da água (Ecokits) - contendo parâmetros tais como $\mathrm{pH}$, turbidez, oxigênio dissolvido, fosfato, etc. - foram sugeridos e cursos regionais de formação de agentes em monitoramento da qualidade da água foram oferecidos. Nesse caso, os PARs poderiam ser uma opção de ferramenta complementar para a avaliação dos recursos hídricos conforme acontece em países como a Alemanha (LUA, 1998) e Estados Unidos (Barbour et al., 1999).

Além disso, deve-se lembrar que os PARs podem ser utilizados pelos CBHs como instrumentos que, de fato, promovam, conforme seus princípios básicos, a participação social, principalmente por meio de programas de educação ambiental voltados para as questões dos recursos hídricos, de forma a assegurar maior participação dos usuários no próprio Comitê, a revisão do Plano de Recursos Hídricos e a efetivação de espaços à participação efetiva dos atores nos processos de gerenciamento ambiental.

\subsection{Perspectivas do uso dos protocolos de avaliação rápida de rios}

Os instrumentos legais foram e continuam sendo criados, contudo, apenas a criação de leis pouco contribui para a consolidação de uma gestão significativamente participativa, ainda mais em um país em que nem sempre o que é disposto por lei é garantido nas relações societárias. A lei sem uma ação de integração e sem uma visão positiva da participação social, pode transformar-se em um extraordinário discurso, utópico e sem aplicabilidade real.

A Lei do Voluntariado (Lei n. 9.608, de 18 de fevereiro de 1998) (Brasil, 1998) estimula o desenvolvimento de metodologias simples e eficientes para avaliação da qualidade ambiental e a transferência dessas tecnologias às comunidades. A estratégia participativa com o uso de grupos de voluntários treinados, seguindo metodologias padronizadas e de eficiência garantida, como é o caso dos PARs, é fundamental para permitir um monitoramento integrado dos sistemas aquáticos em extensas áreas, reduzindo os custos para os órgãos responsáveis pela gestão dos recursos hídricos. Além disso, proporcionam o envolvimento das comunidades locais na apropriação de ferramentas de avaliação, o que pode permitir o debate entre a comunidade e os tomadores de decisão, de forma a buscar o uso sustentável da água em todo o país.

O monitoramento dos recursos hídricos de forma efetivamente participativa requer o desenvolvimento de um processo entendível pela população, que a coloque realmente como agente participante. A implementação de programas de gerenciamento do meio ambiente por métodos que possuem uma linguagem acessível à população, pode promover o envolvimento desta com as questões ambientais e, paulatinamente, um maior interesse dessa comunidade na conservação dos recursos ambientais que a cercam.

A implementação de ferramentas acessíveis às comunidades, como os PARs, representa um grande avanço no sentido da gestão integrada da água, sua conservação e uso racional, no âmbito de uma Política Nacional de Recursos Hídricos. A demanda por dados no monitoramento dos recursos hídricos é grande, e o envolvimento das comunidades em 
projetos ambientais de monitoramento desses recursos, pode ser considerado um instrumento adicional de gestão.

É natural inferir que a utilização dos PARs nos processos de gerenciamento dos recursos hídricos representa um grande desafio a ser enfrentado pelas agências ambientais. É importante ressaltar a necessidade do desenvolvimento de um trabalho bem orientado, inovador e gerador de resultados sólidos para a gestão e o uso sustentável dos recursos hídricos, no sentido de fazer valer a utilização dos PARs como instrumentos que traduzem as reais condições dos recursos hídricos.

É importante que os PARs não sejam vistos apenas como mais um instrumento dirigido pelo Poder Público, de caráter participativo ligado aos processos de gerenciamento ambiental que venham responsabilizar a sociedade/comunidade por possíveis problemas futuros decorrentes da má avaliação ou das conseqüências dos rumos de estratégias de ação formuladas a partir dessa avaliação rápida proposta pelos PARs.

\section{CONSIDERAÇÕES FINAIS}

Baseado no que foi exposto, percebe-se que inserir a sociedade no processo de monitoramento dos recursos hídricos reflete em significativos ganhos na preservação dos ecossistemas lóticos, trazendo entre outros benefícios, a melhoria da qualidade de vida da comunidade, o desenvolvimento da economia local, o crescimento da sociedade e ainda a melhoria na qualidade de ensino. Com uma forma holística de pensar a natureza, os PARs, além de permitirem uma avaliação global do ecossistema fluvial, possibilitam a incorporação da sociedade no processo de gerenciamento do meio ambiente.

É plausível afirmar que a união entre todos os agentes envolvidos na gestão do meio ambiente pode reverter prognósticos ameaçadores e, conseqüentemente, alterar o cenário ambiental caótico em que se encontram vários locais, podendo assim, trazer esperanças sobre um futuro melhor. O método proposto consiste em uma ferramenta simplificada, mas não simplista, de avaliação de rios que, incorporada aos procedimentos metodológicos adotados pelos órgãos gestores, pode aproximar a sociedade civil da questão ambiental.

Quanto mais os atores sociais puderem conhecer, opinar e decidir sobre os problemas que os envolvem, direta ou indiretamente, vendo suas decisões serem implementadas, maior será a consolidação desses espaços, com ganhos mais amplos que extrapolarão o campo dos recursos hídricos.

\section{REFERÊNCIAS}

BARBOUR, M. T.; GERRISTSEN, J.; SNYDER, B. D.; STRIBLING, J. B. Rapid bioassessment protocols for use in streams and wadeable rivers: periphyton, benthic macroinvertebrates and fish. 2. ed. Washington: EPA 841-B-99-002, 1999. 339p.

BARRELLA, W. ; PETRERE JR., M.; SMITH, W. S.; MONTAG, L. F. A. As relações entre as matas ciliares, os rios e os peixes. In: RODRIGUES, R. R.; LEITÃO FILHO, H. (Org.). Matas Ciliares: conservação e recuperação. São Paulo: EDUSP/FAPESP, 2001, p. 187-208.

BRASIL. Ministério do Interior. Secretaria Especial do Meio Ambiente. Portaria GM/0013/15/Jan/1976: classificação das águas interiores do território nacional. Brasília: Gráfica e Editora Itamarati, 1976. 
. Lei das Águas. Lei Federal n. 9.433 de 08 de janeiro de 1997. Institui a Política Nacional de Recursos Hídricos, cria o Sistema Nacional de Gerenciamento de Recursos Hídricos, regulamenta o Inciso XIX do Artigo 21 da Constituição Federal e altera o artigo $1^{\circ}$ da Lei n. 8001 de 13 de março de 1990 que modificou a Lei n. 7990 de 28 de dezembro de 1989. Brasília, 1997.

. Lei do Voluntariado. Lei Federal n. 9.608 de 18 de fevereiro de 1998. Dispõe sobre o serviço voluntariado e dá outras providências. Brasília, 1998.

BUSS, D. F. Proteção à vida aquática, participação das comunidades e políticas de recursos hídricos. Ciência e Ambiente, v. 25, p. 71-84, 2002.

BUSS, D. F.; BAPTISTA, D. F.; NESSIMIAN, J. L. Conceptual basis for the application of biomonitoring on stream water quality programs. Cad. Saúde Pública, v. 19, n. 2, p. 465-473, 2003.

CALLISTO, M. et al. Aplicação de um protocolo de avaliação rápida da diversidade de habitats em atividades de ensino e pesquisa (MG-RJ). Acta Limnologica Brasiliensis, v. 14, n. 1, p. 91-98, 2002.

DAGNINO, E. Os movimentos sociais e a emergência de uma nova noção de cidadania. In: DAGNINO, E. (Org.). Política e sociedade no Brasil. São Paulo: Brasiliense, 1994. p.103-118.

DEL PRETTE, M. E. Apropriação de recursos hídricos e conflitos sociais: a gestão das áreas de proteção aos mananciais da região metropolitana de São Paulo. 2000. Tese (Doutorado em Geografia Humana). Faculdade de Filosofia, Letras e Ciências Humanas - Departamento de Geografia, Universidade de São Paulo, São Paulo, 2000.

EMBRAPA MEIO AMBIENTE. Elaboração de um programa de seleção, capacitação e formação de agentes de água voluntários - subprojeto 1: relatório técnico. Jaguariúna: Embrapa Meio Ambiente, 2003.

GARCIA, A. C. M. M; VALENCIO, N. F. L. S. Gestão de recursos hídricos no Estado de São Paulo: obstáculos técnicos e políticos à sustentabilidade das práticas decisórias em comitês de bacias. In: MARTINS, R.C.; VALENCIO, N.F.L.S. (Org.). Uso e gestão dos recursos hídricos no Brasil: desafios teóricos e político-institucionais. Vol. II. São Carlos: RiMa, 2003.

GUIMARÃES, A. Q.; VIANA, F. E. C.; ANDRADE, G. T. B.; VIANA, L. R. Uso de ferramentas alternativas para auxiliar saídas de campo e construção de valores conservacionistas. In: CONGRESSO IBERO-AMERICANO DE EDUCAÇÃO AMBIENTAL, 5., 2006, Joinville Anais... Brasília: MMA, 2006.HANNAFORD, M. J.; BARBOUR, M. T.; RESH, V. H. Training reduces observer variability in visual-based assessments of stream habitat. J. N. Am. Benthol. Soc., v. 16, n. 4, p. 853-860, 1997.

JACOBI, P. R. Espaços públicos e práticas participativas na gestão do meio ambiente no Brasil. Brasília: UnB, 2003.

A gestão participativa de bacias hidrográficas no Brasil e os desafios do fortalecimento dos espaços públicos colegiados. In: COELHO, V. S. P.; NOBRE, M. Participação e deliberação: teoria democrática e experiências institucionais no Brasil Contemporâneo. São Paulo: Editora 34, 2004. 
. Gestão participativa dos recursos hídricos: reflexões sobre as novas institucionalidades. São Paulo: Secretaria do Meio Ambiente de São Paulo, 2005.

JACOBI, P. R.; BARBI, F. Democracia e participação na gestão dos recursos hídricos no Brasil. Rev. Katál. Florianópolis, v. 10, n. 2, p. 237-244, 2007.

LANDESUMWELTAMT (LUA). Merkblätter nr.14. Gewässerstrukturgüte in NordrheinWestfalen Kartieranleitung (GNWK). Essen: [s.n.], 1998. p. 158

MINATTI-FERREIRA, D. D.; BEAUMORD, A. C. Avaliação rápida de integridade ambiental das sub-bacias do rio Itajaí-Mirim no Município de Brusque, SC. Health and Environmental Journal, v. 4, p. 21-27, 2004.

Adequação de um protocolo de avaliação rápida de integridade ambiental para ecossistemas de rios e riachos: Aspectos físicos. Health and Environmental Journal, v. 7, n. 1, p. 39-47, 2006.

PARSONS, M.; THOMS, M.; NORRIS, R. Australian river assessment system: AusRivAS physical assessment protocol. Monitoring river health initiative technical report number 22. Canberra: Commonwealth of Australia and University of Canberra, 2002.

PLAFKIN, J. L. et al. Rapid bioassessment protocols for use in streams and rivers: benthic macroinvertebrates and fish. Washington: U.S. Environmental Protection Agency, 1989.

PROJETO PAMPULHA LIMPA (PPL). 2006. Disponível em: $<$ http://www.pampulhalimpa.org>. Acesso em: 11 jun. 2008.

PROGRAMA DAS NAÇÕES UNIDAS PARA O DESENVOLVIMENTO (PNUD). Relatório do desenvolvimento humano 2003. Objetivos do desenvolvimento do milênio: Um pacto entre nações para eliminar a pobreza humana. Disponível em: <http://www.pnud.org.br/hdr>. Acesso em: 13 jun. 2008.

PROGRAMA DAS NAÇÕES UNIDAS PARA O DESENVOLVIMENTO (PNUD). Relatório do desenvolvimento humano 2006. A água para lá da escassez: poder, pobreza e a crise mundial da água. Disponível em: <http://www.pnud.org.br/hdr>. Acesso em: 21 jan. 2008.

REDE BRASIL DE ORGANISMOS DE BACIA (REBOB). Disponível em: <www.rebob.org.br>. Acesso em: 12 jan. 2007.

RESH, V. H.; JACKSON, J. K. Rapid assessment approaches to biomonitoring using benthic macroinvertebrates. In: ROSENBERG, D. M.; RESH, V. H. (Org.). Freshwater biomonitoring and benthic macroinvertebrates. New York: Chapman \& Hall, 1993. p. 195-233.

RESH, V. H.; MEYRS, M. J.; HANNAFORD, M. J. Macroinvertebrates as biotic indicators of Environmental Quality. In: HAUER, F. R.; LAMBERTI, G. A. (Org.). Methods in Stream Ecology. San Diego: Academic Press, 1996.

RODRIGUES, A. S. L. Adequação de um protocolo de avaliação rápida para o monitoramento e avaliação ambiental de cursos d'água inseridos em campos rupestres. 2008. 146 f. (Mestrado em Ciências Naturais) - Programa de Pós Graduação em Evolução Crustal e Recursos Naturais, Departamento de Geologia, Universidade Federal de Ouro Preto, Ouro Preto, 2008. 
RODRIGUES, A. S. L.; CASTRO, P. T. A. Protocolos de avaliação rápida: instrumentos complementares no monitoramento dos recursos hídricos. Revista Brasileira de Recursos Hídricos, v. 13, n. 1, 161-170, 2008.

RODRIGUES, A. S. L.; MALAFAIA, G.; CASTRO, P. T. A. Avaliação ambiental de trechos de rios na região de Ouro Preto-MG através de um protocolo de avaliação rápida. Revista de Estudos Ambientais, v. 10, n. 1, p. 74-83, 2008.

SANTOS, B.; AVRITZER, L. Para ampliar o cânone democrático. In: SANTOS, B.; AVRITZER, L. (Org.). Democratizar a democracia. Rio de Janeiro: Civilização Brasileira, 2002. p. 39-82.

SARAIVA, M. G. A. N. O Rio como paisagem. Gestão de corredores fluviais no quadro do ordenamento do território. Lisboa: Fundação Calouste Gulbenkian e Fundação para a Ciência e tecnologia, 1999.

SCHWARZBOLD, A. O que é um rio? Ciência \& Ambiente, v. 21, p. 57-68, 2000.

SILVA, M. et al. Futuro sustentável. Diagnóstico de Ambiente do Grande Porto, 2006. Disponível em: <http://www.futurosustentavel.org>. Acesso em: 10 abr. 2007.

SILVEIRA, M. P. Aplicação do biomonitoramento para avaliação da qualidade da água em rios. Jaguariúna: Embrapa Meio Ambiente, 2004.

TRUSH, W. J.; MCBAIN, S. M.; LEOPOLD, L. B. Attributes of an alluvial river and their relation to water policy and management. PNAS, v. 97, p. 11858- 11863, 2000.

TUNDISI, J. G. Água no século XXI: enfrentando a escassez. São Carlos: Rima, 2003.

UPGREN, A. The development of an integrated ecological assessment of the headwaters of the Araguaia River, Goiás, Brazil. 2004. Dissertação (Mestrado em Gerenciamento Ambiental, Ecossistemas e Conservação) - University of Duke, Durham, 2004. 